ORNL/TM--12284

DE93 010560

Chemical Technology Division

\title{
THE CHANGING STRUCTURE OF THE INTERNATIONAL COMMERCIAL NUCLEAR POWER REACTOR INDUS'TRY
}

\author{
C. W. Forsberg \\ L. J. Hill* \\ W. J. Reich \\ W. J. Rowan ${ }^{\dagger}$
}

\footnotetext{
*Energy Division, Oak Ridge National Laboratory

'William J. Rowan, Consultant, 504 Mountain Breeze, Knoxville, Tennessee 37922-1516
}

Date Published: December 1992

\author{
Prepared by \\ OAK RIDGE NATIONAL LABORATORY \\ Oak Ridge, Tennessee 37831-6285 \\ managed by \\ MARTIN MARIETTA ENERGY SYSTEMS, INC. \\ for the \\ U.S. Department of Energy \\ under contract DE-AC05-84OR21400
}

\section{MASTER}




\section{CONTENTS}

LIST OF FIGURES $\ldots \ldots \ldots \ldots \ldots \ldots \ldots \ldots \ldots \ldots \ldots \ldots \ldots \ldots \ldots$

LIST OF TABLES $\ldots \ldots \ldots \ldots \ldots \ldots \ldots \ldots \ldots \ldots \ldots \ldots \ldots \ldots \ldots$ vii

ACRONYMS AND ABBREVIATIONS $\ldots \ldots \ldots \ldots \ldots \ldots \ldots \ldots \ldots \ldots$ ix

ABSTRACT $\ldots \ldots \ldots \ldots \ldots \ldots \ldots \ldots \ldots \ldots \ldots \ldots \ldots \ldots \ldots \ldots \ldots \ldots$

EXECUTTVE SUMMARY $\ldots \ldots \ldots \ldots \ldots \ldots \ldots \ldots \ldots \ldots \ldots \ldots \ldots \ldots$

1. INTRODUCTION AND OBJECTIVES $\ldots \ldots \ldots \ldots \ldots \ldots \ldots \ldots \ldots \ldots$

2. EVOLUTION OF THE COMMERCIAL NUCLEAR POWER INDUSTRY ... 3

2.1 GOVERNMENT INFLUENCE ................. 3

2.2 INTERNATIONALIZATION OF BUSINESS ............. 4

23 DEMAND FOR ELECTRIC POWER-S CURVE OF NEW

PRODUCT PENETRATION INTO A MARKET . . . . . . . . . . 5

2.4 TECHNICAL CHARACTERISTICS OF NUCLEAR POWER ...... 5

3. VENDORS OF THE NUCLEAR INDUSTRY $\ldots \ldots \ldots \ldots \ldots \ldots \ldots \ldots \ldots \ldots$ 7

$3.1 \quad$ VENDOR HISTORY AND OWNERSHIP $\ldots \ldots \ldots \ldots \ldots \ldots \ldots \ldots 7$

3.1.1 Early History-Technological Experimentation ..........7

3.1.2 Changing Markets and Changing Vendors .............9

3.1.3 Historical Impacts of Nuclear Power on Traditional Vendor and Utility Structure $\ldots \ldots \ldots \ldots \ldots \ldots \ldots \ldots \ldots \ldots \ldots \ldots$

3.2 LOCAL RULES-TECHINICAL CONSTRAINTS ............ 11

3.3 INFLUENCE ON VENDOR DEVELOPMENT ............ 14

3.3.1 Complications and Conditions in the Market .......... 14

3.3.2 Vendor-Utility Relationships ................ 16

3.3.3 Scope of Vendor Responsibility ................ 18

$3.4 \quad$ VARIOUS VENDOR BUSINESS STRUCTURES ............. 19

3.4.1 Parent Corporate Structures ................. 19

3.4.1.1 Government-Owned Vendors ............. 19

3.4.1.2 Large Corporation Vendors .............. 19

3.4.1.3 Keiretsu Vendors . . . . . . . . . . . . . . . . 20

3.4 .2 Joint Ventures $\ldots \ldots \ldots \ldots \ldots \ldots \ldots \ldots \ldots \ldots \ldots \ldots \ldots$

3.4.3 Vendor Business Structures ................. 21

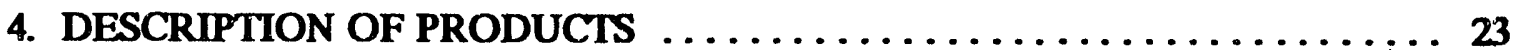

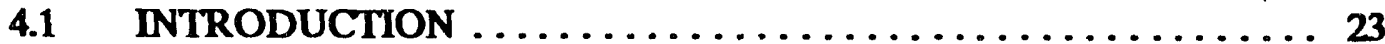

4.2 DESIGN OBJECTIVES . . . . . . . . . . . . . . 23

4.2.1 Economic Requirements ................... 23

4.2.2 Operational/Infrastructure Requirements ........... 24 
4.23 Safety/Public Acceptance Requirements ........... 24

4.24 Regulatory Requirements .................. 26

$4.3 \quad$ PRODUCT DESCRIPTIONS $\ldots \ldots \ldots \ldots \ldots \ldots \ldots \ldots \ldots \ldots$

5. THE CUSTOMER SIDE OF THE MARKET $\ldots \ldots \ldots \ldots \ldots \ldots \ldots \ldots \ldots \ldots . \ldots 29$

5.1 INITIAL SCREENING OF COUNTRIES ............... 29

5.2 COMPLICATING FACTORS .................. 33

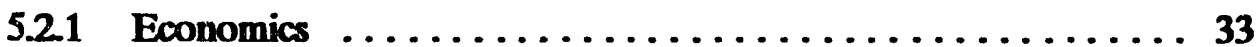

5.22 Indigenous Energy Resources $\ldots \ldots \ldots \ldots \ldots \ldots \ldots \ldots \ldots$

5.2 .3 Public Acceptance $\ldots \ldots \ldots \ldots \ldots \ldots \ldots \ldots \ldots \ldots \ldots \ldots \ldots$

5.2 .4 Financial Cost $\ldots \ldots \ldots \ldots \ldots \ldots \ldots \ldots \ldots \ldots \ldots \ldots \ldots$

5.3 NUCLEAR POWER DECISIONMAKING $\ldots \ldots \ldots \ldots \ldots \ldots \ldots . \ldots$

5.3 .1 Nuclear Countries .................... 36

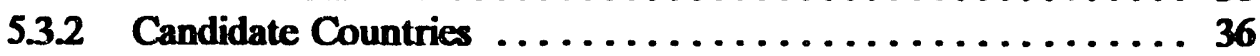

6. CURRENT STRUCTURAL ARRANGEMENTS-WHO IS CONNECTED TO WHOM, WHY, AND IMPLICATIONS

FOR THE FUTURE . . . . . . . . . . . . . . . . . . . . 39

6.1 KEY PLAYERS IN THE WORLD NUCLEAR BUSINESS . . . . . . 39

6.1.1 Nuclear Power Incorporated ................. 39

6.1.2 Asea Brown Boveri .................... 40

6.1.3 Hitachi, General Electric, and Toshiba ...........40

6.1.4 Atomic Energy of Canada Limited ............. 40

6.2 EMERGING NUCLEAR GROUPS ................ 41

6.2.1 Mitsubishi ....................... 41

6.22 South Korea $\ldots \ldots \ldots \ldots \ldots \ldots \ldots \ldots \ldots \ldots \ldots \ldots \ldots \ldots$

6.23 People's Republic of China ....................42

6.3 OTHER NUCLEAR INDUSTRIAL GROUPS . . . . . . . . . 42

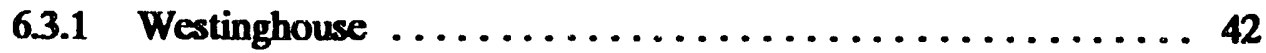

6.3 .2 Russia $\ldots \ldots \ldots \ldots \ldots \ldots \ldots \ldots \ldots \ldots \ldots \ldots \ldots \ldots \ldots \ldots \ldots$

6.3 .3 India $\ldots \ldots \ldots \ldots \ldots \ldots \ldots \ldots \ldots \ldots \ldots \ldots \ldots \ldots \ldots \ldots . \ldots 44$

6.3 .4 New Vendors $\ldots \ldots \ldots \ldots \ldots \ldots \ldots \ldots \ldots \ldots \ldots \ldots \ldots \ldots . . .44$

6.4 COUNTRIES WITH SIGNIFICANT NUCLEAR

POWER PROGRAMS BUT LIMITED DOMESTIC

SUPPLY INDUSTRY $\ldots \ldots \ldots \ldots \ldots \ldots \ldots \ldots \ldots \ldots \ldots$

7. REFERENCES $\ldots \ldots \ldots \ldots \ldots \ldots \ldots \ldots \ldots \ldots \ldots \ldots \ldots \ldots \ldots \ldots \ldots$

Appendix A DATA SHEETS ON THE VENDORS, SUPPLIERS, AND

SIGNIFICANT ORGANIZATIONS IN THE NUCLEAR POWER INDUSTRY . . 49

Appendix B. REACTOR PRODUCTS ................... 87

Appendix C. CUSTOMER BASE FOR NUCLEAR POWER PLANTS $\ldots \ldots \ldots 115$

Appendix D. LIST OF NUCLEAR T UWER REACTORS AND SUPPLIERS $\ldots 137$ 


\section{LIST OF FIGURES}

Fig. 3.1 Vendors, constraining rules, regulations, organizations, and customers . . . 15 


\section{LIST OF TABLES}

Table S1 Nuclear power plant vendors $\ldots \ldots \ldots \ldots \ldots \ldots \ldots \ldots \ldots \ldots \ldots$

Table S2 Summary of candidate and nuclear countries $\ldots \ldots \ldots \ldots \ldots \ldots$ xiii

Table $3.1 \quad$ Major reactor vendors in the world market $\ldots \ldots \ldots \ldots \ldots \ldots \ldots$

Table $4.1 \quad$ Summary of general product characteristics $\ldots \ldots \ldots \ldots \ldots \ldots \ldots$

Table 5.1 Socioeconomic and nuclear indicators for nuclear and candidate countries $\ldots \ldots \ldots \ldots \ldots \ldots \ldots \ldots \ldots \ldots \ldots \ldots \ldots$

Table A.1 Reactor vendors and their organizational relationships $\ldots \ldots \ldots \ldots 52$

Table C.1 Socioeconomic and nuclear indicators major countries of the world, $1990 \ldots \ldots \ldots \ldots \ldots \ldots \ldots \ldots \ldots \ldots \ldots \ldots \ldots$

Table C.2 Electricity generation by fuel type, candidate countries, $1989 \ldots \ldots 122$

Table C.3 Production of conventional thermal electricity, candidate countries, $1988 \ldots \ldots \ldots \ldots \ldots \ldots \ldots \ldots \ldots \ldots \ldots \ldots \ldots \ldots \ldots$

Table C.4 Energy resource, candidate countries $\ldots \ldots \ldots \ldots \ldots \ldots \ldots \ldots$

Table C.5 Electric utilities, candidate countries $\ldots \ldots \ldots \ldots \ldots \ldots \ldots \ldots \ldots$

Table C.6 Electricity generation by fuel type, nuclear countries, $1989 \ldots \ldots$. . . 128

Table C.7 Production of conventional thermal electricity, nuclear countries, $1988 \ldots \ldots \ldots \ldots \ldots \ldots \ldots \ldots \ldots \ldots \ldots \ldots \ldots \ldots . \ldots \ldots$

Table C.8 Energy resources, nuclear countries $\ldots \ldots \ldots \ldots \ldots \ldots \ldots$

Table C.9 Electric utilities, nuclear countries $\ldots \ldots \ldots \ldots \ldots \ldots \ldots \ldots \ldots$

Table D.1 World list of nuclear power reactors operating and under construction $\ldots \ldots \ldots \ldots \ldots \ldots \ldots \ldots \ldots \ldots \ldots \ldots \ldots \ldots$ 


\section{ACRONYMS AND ABBREVIATIONS}

\begin{tabular}{|c|c|}
\hline $\mathrm{ABB}$ & Asea Brown Boveri \\
\hline ADS & automatic depressurization system \\
\hline AEE & Atomenergoexport (Russia) \\
\hline AGR & advanced gas-cooled reactor \\
\hline ANA & Asociacion Nuclear Asco \\
\hline ANPP & Arizona Nuclear Power Project \\
\hline ANV & Asociacion Nuclear Vandellos \\
\hline BEC & Boston Edison Company (USA) \\
\hline BGE & Baltimore Gas and Electric (USA) \\
\hline BKW & Bernische Kraftwerke AG (Germany) \\
\hline BNFL & British Nuclear Fuels \\
\hline bpd & barrels per day \\
\hline BWR & boiling-water reactor \\
\hline CANDU & Canadian deuterium uranium reactor (a type of heavy-water reactor) \\
\hline CEA & Commissariat a L'Energie Atomique (France) \\
\hline CEC & Commonwealth Edison Company (USA) \\
\hline CEIC & Cleveland Electric Illuminating Company (USA) \\
\hline CFE & Comsion Federal de Electricidad \\
\hline CLP & Connecticut Light and Power (USA) \\
\hline CNNC & China National Nuclear Corporation (China) \\
\hline ConEd & Consolidated Edison Company (USA) \\
\hline CPB & Czech Power Board \\
\hline $\mathrm{CPC}$ & Consumers Power Company (USA) \\
\hline CPL & Carolina Power and Light (USA) \\
\hline CYAPC & Connecticut Yankee Atomic Power Company (USA) \\
\hline DAE & Department of Atomic Energy (India) \\
\hline $\mathrm{DE}$ & Detroit Edison (USA) \\
\hline DKB & Dai-ichi Kangyo Bautz (Keiretsu Group) \\
\hline DLC & Duquesne Light Company \\
\hline
\end{tabular}




\begin{tabular}{|c|c|}
\hline DOE & U.S. Department of Energy \\
\hline ECCS & emergency core cooling system \\
\hline EPR & European pressurized-water reactor \\
\hline EPZ & NV Elektriciteits-Producktiemaatschappij Zuid-Nederland (Netherlands) \\
\hline FPC & Florida Power Company (USA) \\
\hline FPL & Florida Power and Light (USA) \\
\hline FSU & Former Soviet Union \\
\hline GKN & Gemeinschaftskernkraftwerk Neckar (Germany) \\
\hline GNPJVC & Guangdong Nuclear Power Joint Venture Company (China) \\
\hline GP & Georgia Power (USA) \\
\hline GPU & General Public Utilities Nuclear (USA) \\
\hline GSU & Gulf State Utilities (USA) \\
\hline HGET & Hitachi, General Electric, Toshiba Joint Venture \\
\hline HLP & Houston Light and Power (USA) \\
\hline $\mathrm{HPC}$ & Hungarian Power Companies, Ltd. \\
\hline HWR & heavy-water reactor \\
\hline IELP & Iowa Electric Light and Power (USA) \\
\hline IMPC & Indiana/Michigan Power Company (USA) \\
\hline IPC & Illinois Power Company (USA) \\
\hline IVO & Imatran Voima Oy \\
\hline JAPCO & Japan Atomic Power Company, Ltd. \\
\hline JCPL & Jersey Central Power and Light (USA) \\
\hline KBR & Kernkraftwerk Brokdorf GmbH (Germany) \\
\hline KEPCO & Korea Electric Power Corporation \\
\hline KKB & Kernkraftwerk Brunsbuettel GmbH (Germany) \\
\hline KKE & Kernkraftwerk Lippe-EMS GmbH (Germany) \\
\hline KKG-D & Kernkraftwerk Goesgen-Daeniken AG (Germany) \\
\hline KKI & Kernkraftwerk Isar (Germany) \\
\hline KKK & Kernkraftwerk Kruemmel GmbH (Germany) \\
\hline KKL & Kernkraftwerk Leibstadt AG (Germany) \\
\hline KKP & Kernkraftwerk Philippsburg (Germany) \\
\hline
\end{tabular}


KKS

KKU

KRB

KTF

KWG

$\mathrm{kWh}$

KWO

MAEP

MBI

MELCO

MHI

MHTGR

MNI

MPS

MSHI

MSUI

MTM

MTU

MW(e)

MT

MW(t)

MYAPC

NCMPA

NE

NEC

NMPC

NNC

NOK

NPCIL

NPPD

NSP
Kernkraftwerk Stade GmbH (Germany)

Kernkraftwerk Unterweser GmbH (Germany)

Kernkraftwerk RWE-Bayernwerk GmbH (Germany)

Kaluga Turbine Factory (FSU)

Gemeinschaftskernkraftwerk Grohnde GmbH (Germany)

kilowatt-hour

Kernkraftwerk Obrigheim GmbH (Germany)

Ministry of Atomic Energy and Industry Minatomenergoprom (FSU)

Ministry of Basic Industries (Cuba)

Mitsubishi Electric Company

Mitsubishi Heavy Industry (Japan)

modular high-temperature gas-cooled reactor

Ministry of the Nuclear Industry (China)

Ministry of Power Stations (FSU)

Mitsubishi (Keirestu Group)

Mitsui (Keiretsu Group)

Mintyazhmash (Russia)

metric tons uranium

megawatts (electrica?,

metric ton

megawatts (thermal)

Maine Yankee Atomic Power Company (USA)

North Carolina Municipal Power Authority (USA)

Nuclear Electric (Great Britain)

National Electric Company (Bulgaria)

Niagara Mohawk Power Company (USA)

National Nuclear Corporation (Great Britain)

Nordostschweizerische Kraftwerk AG (Germany)

Nuclear Power Corporation of India, Ltd.

Nebraska Public Power District (USA)

Northern States Power (USA) 
NSSS nuclear steam supply system

NVGKN NV Gemeenschappelijke Kernenergiecentrale Nederland

NYPA New York Power Authority

OKG OKG Aktiebolag

OPPD Omaha Public Power District (USA)

PAEC Pakistan Atomic Energy Commission

PCCS passive containment cooling system

PCS passive containment spray

PEC Philadelphia Electric Company (USA)

PG\&E Pacific Gas and Electric (USA)

PHWR pressurized heavy-water reactor

PNC Power Reactor and Nuclear Fuel Development Corporation

PNPC Philippines Nuclear Power Corporation

PortGE Portland General Electric (USA)

PPL Pennsylvania Power and Light (USA)

PRHR passive residual heat removal

PRIME passive safety, resilient safety, inherent safety, malevolence resistance, extended time

PSEG Public Service Electricity and Gas (USA)

PSNH Public Service of New Hampshire (USA)

PWR pressurized-water reactor

RBMK water-cooled, graphite-moderated reactor (Chernobyl-type)

RCS reactor coolant system

REA Romania Electricity Authority

RGE Rochester Gas and Electric (USA)

RHR residual heat removal

RPV reactor pressure vessel

RRC Reactor Research Center

SCEC Southern California Edison Company (USA)

SCUAE State Committee for the Use of Atomic Energy (FSU)

SCEGC South Carolina Electric and Gas Company (USA) 


$\begin{array}{ll}\text { SEL } & \text { Savske Elektrarne Ljubijana } \\ \text { SEMS } & \text { Siemens (Germany) } \\ \text { SNL } & \text { Scottish Nuclear Limited } \\ \text { SNOC } & \text { Southern Nuclear Operating Company } \\ \text { SPB } & \text { Slovak Power Board } \\ \text { SPC } & \text { Soyland Power Cooperative (USA) } \\ \text { TEPCO } & \text { Tokyo Electric Power Company (Japan) } \\ \text { TOE } & \text { tons of oil equivalent } \\ \text { TPC } & \text { Taiwan Power Company } \\ \text { TPE } & \text { Technopromexport (Russia) } \\ \text { TVA } & \text { Tennessee Valley Authority (USA) } \\ \text { TVO } & \text { Teollisuuden Voima Oy } \\ \text { TWh } & \text { terawatt-hour } \\ \text { Ukratom } & \text { Ukratomenergoprom } \\ \text { VPC } & \text { Virginia Power Company (USA) } \\ \text { VYNPC } & \text { Vermont Yankee Nuclear Power Corporation (USA) } \\ \text { WCNOC } & \text { Wolf Creek Nuclear Operating Corporation (USA) } \\ \text { WE } & \text { Westinghouse (USA) } \\ \text { WEP } & \text { Wisconsin Electric Power (USA) } \\ \text { WPPSS } & \text { Washington Public Power Supply System (USA) } \\ \text { WPSC } & \text { Wisconsin Public Service Corporation (USA) } \\ & \end{array}$




\title{
The Changing Structure of the International Commercial Nuclear Power Reactor Industry
}

\author{
C. W. Forsberg, L. J. Hill, W. J. Reich, and W. J. Rowan \\ Oak Ridge National Laboratory
}

\begin{abstract}
The objective of this report is to provide an understanding of the international commercial nuclear power industry today and how the industry is evolving. This industry includes reactor vendors, product lines, and utility customers. The evolving structure of the international nuclear power reactor industry implies different organizations making decisions within the nuclear power industry, different outside constraints on those decisions, and different priorities than with the previous structure. At the same time, cultural factors, technical constraints, and historical business relationships allow for an understanding of the organization of the industry, what is likely, and what is unlikely. With such a frame of reference, current trends and future directions can be more readily understood.
\end{abstract}

Before 1980, the dominant reactor vendors were from the United States (Westinghouse, General Electric, Babcock and Wilcox, and Combustion Engineering). These corporationsdirectly or with participation from others-supplied $80 \%$ of the world's power reactors. Since 1980, the major reactor vendors in Europe [Framatome of France, Siemens of Germany, and Asea Brown Boveri (ABB) of Sweden and Switzerland] and in Japan (Mitsubishi, Hitachi, and Toshiba) have dominated new reactor sales. These European and Japanese vendors have supplied $45 \%$ of the world's power reactors since 1980. This change reflects the larger number of power reactors built in Japan and Europe in recent years, the lack of nuclear power plant orders in the United States, the development of foreign nuclear power capabilities, and the financial strengths of these organizations. Russia has a large nuclear power industry (34\% of the world's power reactors since 1980 ), but the Chernobyl nuclear power accident and the collapse of the former Soviet Union have stopped development and created an uncertain future.

Nuclear power suppliers were originally organized along single-country, national lines-national laboratory, national vendor(s), and local utilities, with occasional foreign sales. Since 1980, vendors have been organizing into three types of international groups to reduce business risks and increase sales. First, international corporations such as ABB-the largest industrial equipment manufacturer in the world-own multiple reactor vendors in multiple countries. Second, international joint ventures between multiple reactor vendors have been created to sell, design, and build nuclear power plants. The largest such joint venture and the dominant European group is Nuclear Power Incorporated, which is controlled by Siemens (Germany) and Framatome (France). Last, international consortia for joint sales and product development have been created. A typical example is the Hitachi/General Electric/Toshiba group. More recently, Westinghouse and National Nuclear Corporation (United Kingdom) have formed such a partnership. The parent organizations are much larger than historic national vendors. For example, the historically dominant U.S. vendor, Westinghouse, has annual corporate sales totaling $\$ 12$ billion, while many of the international groups have total annual corporate sales of hundreds of billions of dollars. 
Historically, many types of power reactors have been developed, but today the market is dominated by three types: (1) pressurized-water reactors, (2) boiling-water reactors, and (3) Canadian heavy-water reactors. Several different types of reactors are now in various stages of development. The technology from these development efforts will likely be transferred rapidly throughout the industrial world as a result of the multiple licensing agreements between reactor vendors.

The potential customers for nuclear power plants include utilities in 28 countries that currently operate or are building nuclear power plants, in addition to another 25 countries with economies sufficiently large to support a nuclear power plant. Most future nuclear power reactor sales are expected to be in countries along the Pacific Rim (Japan, China, Indonesia, South Korea, etc.), where the combination of limited domestic energy resources, rapid electrical growth, and reasonable acceptance of nuclear power creates a demand for nuclear power plants. In some of these countries, the markets are open to international sales, while in other countries the markets are closed.

In the 1990s, several additional changes may occur. With the planned Siemens partial buyout of the Czechoslovakia vendor (Skoda Works), Sicmens and NPI partners are well positioned to become the leading nuclear power plant vendor in eastern Europe and the former Soviet Union. Mitsubishi-historically the largest supplier for domestic Japanese power reactors-has aggressively entered the international market. The technical and financial strengths of Mitsubishi Heavy Industries (part of the Mitsubishi family of companies with annual sales of more than $\$ 300$ billion) are likely to have a major impact on the reactor market. Korea has a rapidly growing nuclear power program and is also developing its own vendor capabilities. Currently, it produces $-90 \%$ of the technology in its nuclear power plants. Finally, the People's Republic of China is also developing a vendor capability. Its capability is currently very limited and dependent on foreign equipment, but the potential market that may be captive to the vendor is large. 


\title{
The Changing Structure of the International Commercial Nuclear Power Reactor Industry
}

\author{
C. W. Forsberg, L. J. Hill, W. J. Reich, W. J. Rowan \\ Oak Ridge National Laboratory
}

\section{EXECUTTVE SUMMARY}

The nuclear power reactor industry is in transition. The evolving structure of the international nuclear power reactor industry implies different organizations making decisions within the nuclear power industry, different outside constraints on those decisions, and different priorities than with the previous structure. At the same time, cultural factors, technical constraints, and historical business relationships allow for an understanding of the organization of the industry, what is likely, and what is unlikely. With such a frame of reference, current irends and future directions can be more readily understood.

This report consists of several components. The body of the report provides an overview of the international nuclear power reactor industry-the vendors, the utilities, the constraints, and the current commercial relationships. This overview provides a basis for understanding current developments and predicting likely future activities. The appendixes present additional information with details that may help in understanding the nuclear power industry. This detailed information should also help the reader recognize vendor and utility characteristics that are typical of organizations in various parts of the world.

Historically evolving from U.S. practices, the model for nuclear power reactor development has been as follows: (1) national government supports development of technology, (2) domestic vendor or vendors develop nuclear power plant design, and (3) utilities within the country buy from domestic reactor vendors. Traditional international nuclear power activities consisted primarily of technology-licensing agreements from U.S. vendors to foreign organizations (one-way) and limited sales based on combinations of economic and national policy considerations.

The worldwide nuclear power industry is vecoming an industry based more on commercial considerations; however, there are still numerous constraints imposed by national governments. There are multiple reasons for this transition.

- Government involvement in the development of nuclear power has decreased in the United States and Europe-partly due to the maturity of the industry, the controversy over nuclear power, and the increasing complexity of regulatory requirements. In many countries, government involvement has changed from directing nuclear power development to defining boundaries within which the vendor and utility have freedom of choice.

- There are many large companies (extending across many countries) with capabilities to design and construct nuclear power plants. When the technology was held by a few countries and companies, the number and types of agreements were limited. 
- The cost of developing a new product (reactor) is very high, and the market is uncertain. This creates major incentives for joint ventures to reduce financial and technical risks.

- The internationalization of the controversy over nuclear power has resulted in comparisons of reactor safety requirements worldwide. This is creating strong incentives for vendors and utilities to work together worldwide in developing uniform safety requirements. In some respects, this internationalization follows and historically parallels that of the aircraft industry.

- The utilities in developed countries-the ultimate customer for reactors and the accompanying architectural and engineering services-now better understand nuclear power issues, actively make decisions, and advocate positions to vendors and governments. Historically, utilities have had a commercial (vs government) orientation.

In the last decade, the historical business structures of the nuclear industry have been supplemented with three other types of commercial business organizations. In each case, the vendor objectives are to increase sales and reduce risks by customizing business structures that meet the requirements of the technology and the needs of customers.

- The international corporation sells power reactors in multiple countries through large local subsidiaries, which are, in some instances, reactor vendors themselves. The local subsidiaries meet local market needs. The best example of this structure is the Swedish-Swiss company Asea Brown Boveri (ABB), which owns the nuclear reactor vendors ABB-Atom in Sweden and ABB-Combustion in the United States. Another example of this structure is Siemens, which owns the reactor vendor Kraftwerk Union (Germany) and is buying Skoda (Czechoslovakia). This structure is similar to the relationships in many auto companies (e.g., Ford and Toyota).

- The international joint venture involves multiple vendors creating a joint company to design, sell, and build reactors. Each vendor brings its technical capabilities and customers to the joint venture. The best example is Nuclear Power Incorporated, which is controlled by Siemens (Germany) and Framatome (France), but indirectly may include Skoda of Czechoslovakia (planned Siemens purchase) and Babcock and Wilcox of the United States (a Framatome-controlled company). This structure is similar to the European Airbus consortium in the commercial aircraft industry.

- The international technical/marketing consortium involves multiple vendors developing a joint product with each vendor selling that product to its customers. By custom or by contract, each vendor has a home market (one or more countries), where it has, in many instances, exclusive marketing rights. An example is the Hitachi/General Electric/Toshiba consortium. More recently, Westinghouse and National Nuclear Corporation (United Kingdom) have formed a consortium. Outside of the nuclear power industry, the recently announced Siemens-IBM (International Business Machines)-Toshiba consortium for development of the next generation computer chip provides a good example of such arrangements. 
Two technical characteristics of nuclear power have provided strong incentives for internationalization of the industry.

- The size of nuclear power plants has increased to improve the economics of nuclear power. A single power plant now costs several billion dollars. Only very large corporations or consortiums can handle the financing and business risks associated with such large facilities.

- A significant fraction of the total cost of a nuclear power plant is associated with design and development. These costs are the same if one or ten plants are sold. This creates a powerful economic incentive for multiple vendors in different nations to develop a common design and spread the development costs over the maximum number of plant sales in multiple countries. This phenomenon is similar to what is happening in the aircraft industry, where Boeing is in partnership with Japanese companies and where the European Airbus consortium includes French, German, and Spanish partners.

The above considerations have several implications. First, techıology developed in any country rapidly diffuses around the world through these business relationships. Second, it is economically costly for a country to go it alone in developing this type of technological product.

Table S1 identifies major reactor vendors in the world and indicates their sizes and significant corporate interconnections. Several conclusions can be drawn. The largest vendors in terms of recent construction starts are from France, Germany, and Japan. These vendors are backed by national governments, large corporations, or large groups of companies. A special case is the Russian vendor, where a large nuclear power program existed until the Chernobyl nuclear power reactor accident and the breakup of the former Soviet Union. Its future is uncertain. In the 1990s, current developments will lead to reactor vendor capabilities in South Korea and China. Last, because it is very expensive to operate independently, international agreements or partnerships have become the norm.

The vendor product is the nuclear power reactor. Three technologies are now marketed: two types of light-water reactors and one type of heavy-water reactor. The current technologies have one characteristic that impacts the industry-the chosen technologies have significant economics of plant size. Vendors have stressed the development of large plants. The large size of current power reactors and the required support infrastructure confines sales to countries with large electric demands, large electrical grids, and large utilities within countries.

The utilities are the vendor's customers. The decision to buy a nuclear power plant depends on local conditions. Table S2 summarizes characteristics of candidate nuclear countries (i.e., countries not operating or constructing nuclear power plants, but with economies of sufficient size to support one) and nuclear countries (currently operating or constructing nuclear power plants). The vendor for the power plant may be chosen by political, cultural, economic, or technical criteria. As listed below, several conclusions can be drawn from Table S2 and an examination of worldwide utility practices. 
Table S1. Nuclear power plant vendors

\begin{tabular}{c} 
Country \\
Company \\
Vendor \\
\hline Canada
\end{tabular}

Power reactor construction starts since Approximate $1980^{\mathrm{a}}$ total corporate sales ( $\$$ billion)

Comments

Atomic Energy of Canada

\section{China}

China National Nuclear Corporation

France

Commissariat a

L'Energie Atomic (CEA)

Framatome (France)

Babcock \& Wilcox (U.S.)

\section{Germany}

\section{Siemens}

Kraftwerk Union

(Germany)

Skoda (Czechoslovakia)

\section{Great Britain}

National Nuclear

Corporation (NNC)

4

9

1

Gov $^{\mathrm{C}}$

20

Gov

Gov

Sole international supplier of heavy-water reactors, technical agreements with South Korea

Planned rapid expansion in 1990 s, currently somewhat limited capabilities

Past owner with Siemens of joint venture: Nuclear Powsr Incorporated

41/Mixed

Mixed

Multiple agreements with Westinghouse: joint venture to build the first British pressurized-water reactor, agreement for joint bids on foreign plants

\section{India}

Department of Atomic

8

Gove Energy
Gove
Part owner with venture: Nuclear Power Incorporated Framatome of joint

Local vendor: no significant international activities, relatively small power reactors 
Table S1. Nuclear pow yr plant vendors (continued)

Country
Company
Vendor

Hitachi

Mitsubishi Heavy Industry

(MHI) and Mitsubishi

Electric Co. (MELCO)

Toshiba

Russia

Minatom

\section{South Korea}

Korea Heavy Industries and

Construction Co.
Power reactor construction starts since $1980^{\circ}$

6

11

7

36

20 (MHI) 25 (MELCO)

43

Gov

Mixed

5

\section{Sweden/Switzerland}

\author{
Asea Brown Boveri (ABB) \\ $A B B$ Atom (Sweden) \\ $A B B$ Combustion (U.S.)
} 27
Approximate

total corporate

sales ( $\$$ billion)

Comments
55

Parger Dia-ichi

Kangyo Bank Group with 688 member companies, member of $\mathrm{HGET}^{\circ}$ joint product development consortium

Part of larger Mitsubishi Group with sales of $\$ 300 x$ $10^{9}$ /year; agreements with Westinghouse

Part of the larger Mitsui Group with 489 member companies, member of HGET $^{b}$ joint product development consortium

Uncertain future; only major vendor not part of larger international consortium, many reactor construction projects shut down or cancelled

Building Korean reactors with Asea Brown Boveri, Korean content $\mathbf{- 9 0 \% \text { , }}$ approaching independent vendor status

Largest industrial and utility equipment manufacturing company in world, technical agreements with South Korea 
Table S1. Nuclear power plant vendors (continued)

\begin{tabular}{lccc}
$\begin{array}{c}\text { Country } \\
\text { Company } \\
\text { Vendor }\end{array}$ & $\begin{array}{c}\text { Power reactor } \\
\text { construction } \\
\text { starts since } \\
1980^{a}\end{array}$ & $\begin{array}{c}\text { Approximate } \\
\text { total corporate } \\
\text { sales }(\$ \text { billion })\end{array}$ & Comments \\
\hline $\begin{array}{l}\text { Jnited States } \\
\text { General Electric }\end{array}$ & 50 & $\begin{array}{l}\text { Member of HGET joint } \\
\text { product development } \\
\text { consortium }\end{array}$ \\
Westinghouse & 3 & 12 & $\begin{array}{l}\text { New agreement on future } \\
\text { reactors with Mitsubishi, } \\
\text { technical agreement with } \\
\text { NNC and others }\end{array}$ \\
\hline
\end{tabular}

'Power reactors sold with start of construction after 1980 . There have been major changes in market share among vendors over the last several decades. A power reactor requires 4 to 12 years to build. Listing reactors with start of construction since 1980 provides an estimate of recent vendor sales and capabilities. Construction starts rather than reactor sales provides the best measure of vendor business since some sales fail and some sales are, in fact, options for purchase.

${ }^{b}$ HGET = Hitachi/General Electric/Toshiba.

${ }^{c}$ Gov = government agency.

${ }^{d}$ Siemens has an agreement with Skoda to buy a controlling share of the Skoda division responsible for commercial nuclear power equipment. 
Table S2. Summary of candidate and nuclear countries"

\begin{tabular}{|c|c|c|c|c|c|}
\hline \multirow[b]{2}{*}{$\begin{array}{l}\text { Income level } \\
\text { Country }\end{array}$} & \multicolumn{3}{|c|}{ Electric generating capacity (GW) } & \multirow[b]{2}{*}{$\begin{array}{c}\text { Type and number } \\
\text { of utility } \\
\text { organization }\end{array}$} & \multirow[b]{2}{*}{$\begin{array}{l}\text { Single } \\
\text { vendore }\end{array}$} \\
\hline & Total & $\begin{array}{l}\text { Nuclear } \\
\text { operating }\end{array}$ & $\begin{array}{c}\text { Nuclear } \\
\text { construction } \\
\text { in progress }\end{array}$ & & \\
\hline \multicolumn{6}{|l|}{ Low-income } \\
\hline Nigeria & 4.0 & 0.0 & 0.0 & N1 & NA \\
\hline India & 69.9 & 1.4 & 1.5 & NM, RM & YG \\
\hline China & 98.0 & 0,0 & 2.1 & N1, RM & YG \\
\hline Pakistan & 8.5 & 0.1 & 0.0 & N1, R1 & $\mathbf{N}$ \\
\hline Indonesia & 11.0 & 0.0 & 0.0 & N1 & NA \\
\hline Egypt & 11.0 & 0.0 & 0.0 & $\mathbf{N} 1, \mathbf{R M}$ & NA \\
\hline Cuba & 3.2 & 0.0 & 0.8 & N1 & YN \\
\hline \multicolumn{6}{|c|}{ Lower middle-income } \\
\hline Philippines & 6.6 & 0.0 & 0.6 & N1, RM & $\mathbf{N}$ \\
\hline Peru & 2.7 & 0.0 & 0.0 & N1, R8 & NA \\
\hline Colombia & 8.9 & 0.0 & 0.0 & N3, RM & NA \\
\hline Thailand & 7.9 & 0.0 & 0.0 & N1, R2 & NA \\
\hline Turkey & 14.6 & 0.0 & 0.0 & N1, P1 & NA \\
\hline Romania & 22.9 & 0.0 & 3.1 & N1 & $\mathbf{N}$ \\
\hline Poland & 32.0 & 0.0 & 0.0 & N1 & NA \\
\hline Algeria & 3.8 & 0.0 & 0.0 & N1, R1 & NA \\
\hline Bulgaria & 11.1 & 2.6 & 1.9 & N1 & YN \\
\hline Malaysia & 4.4 & 0.0 & 0.0 & $\mathbf{R} 3$ & NA \\
\hline Argentina & 16.6 & 0.9 & 0.7 & NM, RM & $\mathbf{N}$ \\
\hline Iran & 13.8 & 0.0 & 2.4 & N1 & $\mathbf{N}$ \\
\hline \multicolumn{6}{|c|}{ UPper middle-income } \\
\hline Mexico & 28.0 & 0.7 & 0.7 & $\mathrm{~N} 1, \mathrm{P} 1$ & $\mathbf{N}$ \\
\hline South Africa & 26.5 & 1.8 & 0.0 & $\mathbf{N} 1, \mathbf{R M}$ & $\mathbf{N}$ \\
\hline Venezuela & 17.7 & 0.0 & 0.0 & N6, P7 & NA \\
\hline Brazil & 52.1 & 0.6 & 1.2 & NM, PM & $\mathbf{N}$ \\
\hline Hungary & 6.4 & 1.6 & 0.0 & N1 & YN \\
\hline Yugoslavia & 15.8 & 0.6 & 0.0 & War & $\mathbf{N}$ \\
\hline Czechoslovakia & 17.7 & 3.3 & 3.3 & $\mathrm{~N} 1$ & YN \\
\hline Former USSR & 341.0 & 34.7 & 21.3 & R12 & YG \\
\hline Portugal & 6.8 & 0.0 & 0.0 & N1 & NA \\
\hline South Korea & 23.5 & 7.2 & 1.9 & N1, P1 & $\mathbf{Y}$ \\
\hline
\end{tabular}


Table S2. Summary of candidate and nuclear countries" (continued)

\begin{tabular}{|c|c|c|c|c|c|}
\hline \multirow[b]{2}{*}{$\begin{array}{l}\text { Income level } \\
\text { Country }\end{array}$} & \multicolumn{3}{|c|}{ Electric generating capacity $(\mathrm{GW})^{\mathrm{c}}$} & \multirow[b]{2}{*}{$\begin{array}{c}\begin{array}{c}\text { Utility } \\
\text { organization }\end{array} \\
\text { Type - \# }\end{array}$} & \multirow[b]{2}{*}{$\begin{array}{l}\text { Single } \\
\text { vendor }^{\mathrm{e}}\end{array}$} \\
\hline & Total & $\begin{array}{l}\text { Nuclear } \\
\text { operating }\end{array}$ & $\begin{array}{l}\text { Nuclear } \\
\text { construction } \\
\text { in progress }\end{array}$ & & \\
\hline \multicolumn{6}{|l|}{ High-income } \\
\hline Greece & 8.2 & 0.0 & 0.0 & N1, N1 & NA \\
\hline Saudi Arabia & 16.5 & 0.0 & 0.0 & N1, PM & NA \\
\hline Ireland & 3.7 & 0.0 & 0.0 & N1 & NA \\
\hline Israel & 4.1 & 0.0 & 0.0 & N1 & NA \\
\hline Spain & 42.7 & 7.1 & 0.0 & NM, RM & $\mathbf{N}$ \\
\hline Singapore & 3.4 & 0.0 & 0.0 & N1 & NA \\
\hline Hong Kong & 7.5 & 0.0 & 0.0 & P2 & NA \\
\hline New Zealand & 7.0 & 0.0 & 0.0 & N1, RM & NA \\
\hline Belgium & 13.4 & 5.5 & 0.0 & N1, R2, P3 & $\mathbf{N}$ \\
\hline United Kingdom & 71.4 & 11.5 & 1.2 & PM & YG \\
\hline Italy & 50.0 & 0.0 & 0.0 & & $\mathbf{N}$ \\
\hline Australia & 35.0 & 0.0 & 0.0 & R8 & NA \\
\hline Netherlands & 17.3 & 0.5 & 0.0 & NM, RM & $\mathbf{N}$ \\
\hline Austria & 15.2 & 0.0 & 0.0 & $\mathrm{~N} 1, \mathbf{R M}$ & NA \\
\hline France & 91.8 & 55.8 & 8.3 & N1 & YG \\
\hline Canada & 102.2 & 14.0 & 1.8 & & YG \\
\hline United States & 684.7 & 100.6 & 1.2 & NM,RM,PM & $\mathbf{N}$ \\
\hline Denmark & 8.7 & 0.0 & 0.0 & $\mathrm{MM}$ & NA \\
\hline Germany & 99.0 & 24.4 & 3.3 & PM & $\mathbf{Y}$ \\
\hline Norway & 26.7 & 0.0 & 0.0 & NM, RM, PM & NA \\
\hline Sweden & 31.5 & 9.8 & 0.0 & N2, RM & $\mathbf{N}$ \\
\hline Japan & 181.9 & 30.9 & 9.0 & N1, RM, P10 & $\mathbf{Y}$ \\
\hline Finland & 11.0 & 2.3 & 0.0 & N1, RM, P12 & $\mathbf{N}$ \\
\hline Switzerland & 15.3 & 3.0 & 0.0 & N1, RM, PM & $\mathbf{N}$ \\
\hline
\end{tabular}

\footnotetext{
'Source: Adapted from Tables C.1 through C.9 in Appendix C.

oTotal and nuclear refer to total electric generating capacity and nuclear capacity, respectively, in 1990. Construct means the amount of nuclear capacity under construction.

bBased on the World Bank's classification of countries using per-capita income. Countries with $\$ 610$ or less of per-capita income are low-income; those with $\$ 7,620$ or more are classified as high-income.

The entries in this column designate the organizational structure of the electric power sector in each of the countries. The first character in any two-character sequence refers to the ownership of the electric utilities: $\mathbf{N}=$ owned by the national government; $R$ = owned by a regional (city, county, district) government; $P=$ owned by the private sector, $M=$ mixed, public-private ownership. The second character refers to the number of utilities in the country with that type of ownership, with $M$ meaning many or multiple. A designation N1, R3, for example, means that the country has one utility owned by the national government and three owned by regional governments. In this example, the country has no privately owned utilities.

'Y indicates that utilities historically buy from the same vendor. YG indicates government-owned vendors and utilities; YN indicates utilities historically have bought from a particular nongovernment vendor. (These relationships may have changed with the breakup of the former Soviet Union.) $\mathrm{NA}=$ not applicable; $\mathrm{N}$ indicates no fixed vendor/customer relationship.
} 
- The size and cost of nuclear power plants limit their construction to countries with large incomes. The candidate countries in Table S2 are all countries presently without nuclear power and with a total annual income in excess of $\$ 30$ billion in 1990 (see Appendix C), the lowest national income level (with the exception of Bulgaria) of countries currently operating or constructing nuclear power plants.

- Different countries use different approaches in organizing their utility industries which, in turn, implies different types of decision makers choosing to build or not to build nuclear power plants.

- Many countries have one large government-owned/controlled utility (e.g., France, South Korea) where the decision to build a nuclear power plant lies with the government. In such cases, the government may, through the utility, select the reactor vendor or force the creation of a local vendor. France historically used this mechanism to create a local nuclear power vendor. South Korea and China are currently using the mechanism to create new national reactor vendors in the 1990 s.

- Other countries have a large number of utilities with mixed governmentprivate ownership. For example, the decision to construct a nuclear power plant in the United States does not rest with the government, but with the managers of the 2000 utilities.

- $\quad$ The structure (number and type) of the utility industry in a country influences the use of nuclear power. In countries such as Japan (where there are only nine very large utilities), there are few financial, managerial, or technical constraints on choice of power plant. In countries such as the United States, (with thousands of utilities), only the large utilities have the resources to build nuclear power plants.

- In many countries, a utility, for political or cultural reasons, must buy nuclear power plants from a specified vendor. This includes (1) countries with national (i.e., government-owned) utilities and national vendors (France, Russia, India, China, Canada); (2) countries with business cultures where long-term vendor-utility relations have evolved (Japan, Germany); and (3) countries where national policy dictates choice. In many cases (France, Japan, Canada), the utilities have very powerful influences on the vendors and many times influence vendor decisions. The vendor, in turn, may develop the technology, license the technology from another vendor, or form a partnership with another vendor to obtain the product the utility wants.

- In other countries (the United States, Sweden, Switzerland, Belgium, Spain, etc.), the utilities have more freedom in choosing vendors. They may make their decision based on economics (including financing) and technology; however, other factors usually limit the choices to a few select vendors. These factors include the following:

- $\quad$ Previous experience with the vendor in nuclear and nonnuclear transactions. Power plants are expected to last $\mathbf{3 0}$ to $\mathbf{4 0}$ years. The equipment lifetime is 
longer than in most industries. The utility prefers a vendor to support his product for the life of the plant. Long equipment lifetimes imply long customer-vendor relationships. Commercial relationships are slow to form ur break.

- $\quad$ Reputation of the vendor. In the 1980 s, the sales of reactors to countries without national vendors indicated that vendors with the most reliable reactors made the most sales.

- Cultural factors, standardization of requirements, and codification of criteria. Language, cultural factors, and national engineering codes strongly influence decisions. Building a power plant is complicaied; thus, factors which aid communication have a significant impact on the selection of vendors.

- Most new orders for nuclear power plants in the 1990s are expected in Pacific rim countries (Japan, South Korea, China, Indonesia, and Taiwan). This reflects rapid economic growth with rapid growth in electrical demand, limited local energy resources, reasonable acceptance of nuclear power, and total electrical demands sufficiently large that large nuclear power plants are compatible with the local electric grid. Nuclear power growth in Europe is expected to be slower due to smaller growth in electric demand, saturation of nuclear power capacity in selected countries (France), and controversy over nuclear power.

The transitions in the nuclear power industry imply different organizations and individuals making key decisions. Utility and commercial considerations are becoming more important with less influence by governments. The industry is becoming international. Understanding historic commercial relationships and the evolving technology has become the basis for identifying likely future trends. 


\section{INTRODUCTION AND OBJECTTVES}

The objective of this report is to provide an understanding of the international commercial nuclear power reactor market, including the suppliers, the products, and the customers. This objective includes two major components:

1. Identifying (1) major commercial reactor suppliers, (2) existing and future product lines, (3) influences on customers/practices, (4) views on market strategies, (5) major partnerships and agreements, and (6) customer [utility] constraints.

2. Understanding the slowly evolving connections between suppliers, technologies, customers, and national governments. The choice of nuclear reactor by a utility is determined not only by economics, but cultural factors, historical business relationships, and national policies.

Understanding the structure of the nuclear power industry provides an insight on why particular events occurred, provides a framework to understand what may occur, and a mechanism to understand what occurrences are unlikely.

The body of this report presents an overview of the structure of the industry, while the appendixes (70\% of the report) provide more detailed reference information. Section 2 provides an overview of the structure of the international nuclear industry and its evolution with time. Section 3 describes vendors, their environments, and the apparent strategies of reactor suppliers. Section 4 describes the product lines, while Section 5 provides an understanding of the customers (utilities with various constraints on decisions). The possible philosophies and strategies of particular vendors combined with the constraints of utilities imply that when a utility orders a power plant, in practice, only one or a few vendors are possible suppliers. These relationships are described in Section 6. 


\section{EVOLUTION OF THE COMMERCIAL NUCLEAR POWER INDUSTRY}

The structure of the international nuclear power industry is rapidly changing. This study provides a snapshot of that structure today, but to understand the structure and its possible future direction, some understanding of the key historical driving forces for change is required. Four primary factors have influenced the historical evolution of commercial nuclear power: government, internationalization of business, growth in electric demand, and technology.

\section{GOVERNMENT INFLUENCE}

Historically, national governments have been the dominant influence on the structure of the commercial nuclear power industry. As a commercial industry, nuclear power is unusual in this aspect. The original technology was developed by national governments for defense purposes. Thus, transition from national defense activity to commercial activity was required. That transition is currently not complete, and it may never be fully complete in all countries.

Commercial nuclear power worldwide is also influenced by government concerns about strategic energy availability, international balance of trade, and national eimployment. These influences have been major factors in European and Japanese government nuclear power policies to support national vendors and utilities. To understand these issues, some technical characteristics of nuclear power compared to other energy sources must be understood. The costs of electricity depend upon capital facilities costs, operating costs, and fuel costs. Fuel costs include cost of uranium, fuel preparation, transport, and waste disposal. The cost of the uranium is extremely low $-\$ 0.0014 / \mathrm{kWh}$ of electricity generation ( $\$ 20 / \mathrm{lb}$ uranium). When the other fuel cost components (conversion, enrichment, fabrication, and waste disposal) are added, the total nuclear fuel cost is $\$ 0.006 / \mathrm{kWh}$. For comparison, the cost of oil is $\$ 0.0300 / \mathrm{kWh}$ of electricity generated (\$20/barrel with $40 \%$ conversion efficiency), and the cost of coal is $\$ 0.0150 / \mathrm{kWh}$ of electricity generated ( $\$ 40 /$ ton with $37 \%$ conversion efficiency).

Fuel availability is a major issue for governments in industrialized countries. For energy security by stockpiling of fuel, nuclear power offers two advantages: (1) the cost is low (10\% of that of coal for equivalent energy), and (2) storage is easy (more than four orders of magnitude less mass than the mass of coal for equivalent energy). Furthermore, uranium, unlike coal or oil, will not degrade in storage.

Some countries have problems with the balance of trade. If they do not have internal energy resources, uranium is the preferred fuel because it costs the least. Less than $5 \%$ of the electricity cost from nuclear power is associated with uranium cost vs $>50 \%$ of the cost of electricity from oil. This low associated fuel cost for uranium minimizes expenditure of scarce hard currency.

Nuclear power can use domestic employment; the employment is associated primarily with construction and operation of power plants rather than obtaining fuel. Much of the employment with fossil production of electricity is associated with the mining and transport of fuel. 
Last, in addition to economic and energy concerns, there has been continued concern about nuclear weapons proliferation and the potential use of civilian nuclear power technology as a stepping stone to weapons production. This concern has resulted in various treaties and agreements to restrict certain nuclear power technologies.

\section{INTERNATIONALIZATION OF BUSINESS}

The nuclear power supply industry (vendors) has become an international industry. In part, this reflects the general trend of rapid economic growth in international trade and formation of multinational enterprises. This broad economic development is a result of political developments such as lowering of trade barriers and formation of free trade zones (e.g., the European Common Market). The internationalization of the nuclear power supply industry is also the result of certain economic characteristics of high technology industries. These characteristics provide strong incentives for internationalization of suppliers. A comparison of the steel and commercial aircraft industry can highlight these differences.

The costs of producing steel depend upon the costs of facilities, raw materiais, and labor. Steel technology is not changing rapidly, thus, few resources are required for development of steel making technology. The product is also well defined. There are economies of scale up to a certain size. An international steel company with many steel plants may have only a small economic advantage over a steel company with a few facilities.

The commercial aircraft industry (Boeing, Airbus, etc.) has a fundamentally different cost structure. The development and licensing costs for a new commercial aircraft are measured in billions of dollars. Product development costs are extremely high. If the aircraft manufacturer doubles production of a new aircraft, additional facilities may cost a few hundred million dollars plus operating costs; however, the cost per aircraft drops dramatically because development and licensing costs are a significant fraction of total costs and independent of the number of aircraft produced. If partnerships or joint ventures with other companies can increase sales, this drastically reduces unit costs, reduces risks, and increases profits for all partners. The Boeing/Japan partnership and the Airbus consortium (French, German, Spanish companies) are designed to ensure wider markets for expensive-to-develop aircraft. The electronic integrated circuit industry is also similar except that the costs involve developing the production technology. The recent joint venture of IBM (United States), Toshiba (Japan), and Siemens (Germany) to develop the next generation of computer memory chip is a mechanism to spread the process development costs over products sold in North America, Japan, and Europe (Wallace 1992). In industries where product or process development costs are a major fraction of total costs, there are powerful incentives for international cooperation that spread development cost/risk over expanded markets.

The economics of constructing nuclear power plants are closer to the aircraft industry than the steel industry; thus, there are potentially large vendor economics of scale. National governments may prefer domestic suppliers, but unlike the steel industry, the economies push for either international companies or domestic companies as part of larger international consortia to spread development costs, minimize risks, and maximize markets. 


\section{DEMAND FOR ELECTRIC POWER-S CURVE OF NEW PRODUCT PENETRATION INTO A MARKET}

New technologies and new products penetrate markets over a period of time. For most products, the rate of penetration as a function of time is described as a flattened $S$ curve. When a product is first introduced, it slowly enters the market. As people learn about the new product, its acceptance increases rapidly and costs drop. Eventually, the market saturates and the demand for the product is limited by the replacement market and population growth. This applies to growth in demand for electricity and demand for nuclear power stations, and this phenomenon impacts which utilities will buy nuclear power plants.

The growth of electric demand in the United States provides an example of this phenomenon. The electric power industry started in the late $1800 \mathrm{~s}$. By the early part of the 1900 s, electricity demand grew rapidly, slowed only by the great depression of the 1930s. Initially, electricity replaced other energy sources-electric lights for oil lamps and electric motors for factory steam engines. Later, new applications appeared-air conditioning and electronics. After decades of rapid growth, the electric growth rate slowed in the 1970s. At the time, it was assumed that the decreased growth rate was primarily due to the oil shocks, but today it is recognized that the slowdown would have occurred within a decade due to saturated demand. By the $1970 \mathrm{~s}$, the massive retrofit of factories and homes for air conditioning, electrification of home appliances, and other new uses were approaching saturation.

The change in growth rate for electric power drives the market for nuclear plants. The slowdown in growth of electric demand in the United States in the 1970s resulted in the cancellation of hundreds of planned coal, nuclear, and gas-fired power stations. This, in turn, shrank the size of the U.S. nuclear supply industry. Alternately, the rapid growth in electric power demand as part of the industrial development cycle in South Korea and Taiwan provides a major market for nuclear power stations and the home market for the emerging South Korean reactor vendor.

The S-curve phenomenon also applies to the growth of nuclear power to replace other sources of energy for electric power production. In a country, such as the United States, with $20 \%$ of the electricity from nuclear power, a significant growth of nuclear power is possible. In contrast, in a country such as France with $70 \%$ of the electricity from nuclear power, future nuclear power growth is limited by electric demand.

\section{TECHNICAL CHARACTERISTICS OF NUCLEAR POWER}

As currently designed, the economics of nuclear power favor very large power plants. Plant operations are complex and require a significant infrastructure for efficient operations. These technical characteristics limit the nuclear power market to large utility systems-primarily in large developed countries. Such technical limitations are unusual when compared to most other industrial products. Countries with large internal markets usually have large, local industrial suppliers. This is in contrast to the aircraft and integrated circuit electronics industries where significant markets exist outside the countries manufacturing the products. 
Within the nuclear industry, there is considerable debate as to whether or not economies of scale are intrinsic characteristics of nuclear power or results of the historical development of the technology. If the technology were to change to allow smaller power plants, the industrial structure would be significantly altered. 


\section{VENDORS OF THE NUCLEAR INDUSTRY}

Each nuclear vendor organization has a unique set of conditions that dominate its existence and growth. This section discusses many of these conditions-how they influence vendor growth, the competitive climate in the industry, and the strength of various reactor vendors. The major factors influencing vendor development have been placed in the following groups for discussion in this chapter:

- vendor history and ownership,

- local codes and technical constraints,

- influences on vendor development, and

- various vendor business structures.

A short summary on the competitive status of vendors is provided at the end of this chaptel.

\subsection{VENDOR HISTORY AND OWNERSHIP}

\subsubsection{Early History-Technological Experimentation}

The first type of reactor to be commercialized was the light-water reactor (LWR). The LWR is a direct outgrowth of development of pressurized-water reactors (PWRs) for propulsion of U.S. nuclear power submarines. Before the development of nuclear power, submarines were powered by diesel engines when on the surface and battery-powered electric motors when under water. When the United States decided to develop nuclear power reactors for submarines, two contractors with experience in submarine propulsion (electrical equipment) were chosen-General Electric and Westinghouse Electric. The two companies were, at that time, the major U.S. suppliers of utility electrical equipment. Based on their experience with navy reactors, these two companies became the major commercial nuclear reactor vendors worldwide in the 1960 s and 1970s. Two other U.S. companies also successfully entered the nuclear power business-Babcock and Wilcox and Combustion Engineering. These companies had also been involved in the submarine program and were, historically, the dominant suppliers of stean boilers for production of electricity from fossil fuels in the United States. These companies worked on LWR nuclear plants for the public utilities while the U.S. Government continued to conduct research and development (R\&D) on hea ry-water reactors (HWRs), gas-cooled reactors (GCRs), and liquid metal reactors (LMRs). In the United Kingdom, GCR work was being performed by British companies for their utilities, while LMR work was conducted in their government laboratories. The Canadian Government was developing HWR plants for its utilities. The Russians were developing PWRs, graphite moderated LWRs, and liquid-metal fast breeder reactors. The numerous military and government $R \& D$ programs continued to make major contributions to the technology.

During this period, the U.S., U.K., German, Swedish, Swiss, and Japanese major manufacturers of fossil power plant equipment were setting up nuclear power plant divisions. In other parts of the world, governments were initiating nuclear programs to explore the technology and potential contributions to the energy supply. The Americans, British, and 
Canadians had a cadre of trained engineers from defense programs. With their knowledge of the new technology, these engineers rapidly moved into the newly created nuclear divisions of established suppliers of commercial power generation equipment vendors. In Canada, France, and Russia, the governments were aggressively developing their technological base. There was an exciting national pride about these efforts and the development of capabilities.

By 1970, the U.S.-designed LWRs dominated the world market. This was a result of the initial development of nuclear power in the United States and the classified characteristics of the technology in its early years, which allowed only U.S. companies access to the technology. The LWR became the dominant technology because (1) more resources were spent to develop this technology than any other technology and (2) technical requirements for Navy propulsion reactors (supply steam to turbine to power propeller) were similar to utility requirements (supply steam to turbine to power electric generator). As one historian noted (Arthur 1990), "the role of the U.S. Navy in early reactor construction contracts, efforts by the National Security Council to get a reactor-any reactor-working on land in the wake of the 1957 Sputnik launch ... all acted to favor the early development of light-water reactors . . . ." Many foreign equipment suppliers obtained technology licenses from U.S. vendors to build nuclear power plants in their own countries. The advanced development of the LWR ultimately resulted in it becoming the preferred reactor in most countries, but the condition for sale in many countries was design and construction of the reactors by local vendors under license from U.S. vendors.

General Electric and Westinghouse, along with Babcock \& Wilcox and Combustion Engineering, were competing for the U.S. domestic business. Two types of LWRs were developed: (1) the PWR and (2) the boiling-water reactor (BWR). In the U.S. the nuclear plant selection issue was influenced by the decision to use a BWR vs a PWR as much as the desire to go with a particular vendor. General Electric promoted and dominated the BWR field while Westinghouse promoted and dominated the PWR field. In many other countries, the preferred type of reactor was determined by which U.S. company licensed technology to the local vendor.

There were three important exceptions to U.S.-designed LWRs dominating the world market. The first is a company called Asea Brown Boveri (ABB). In the 1960s, ABB was a large Swedish company that decided to independently develop its own LWR technology (Kaijser 1992). It was very successful and built the most reliable LWRs in the world (Knox 1992). For decades ABB has been one of the most rapidly growing industrial companies in the world and is now the world's largest industrial equipment supplier, a major force in the international nuclear power industry, and a major exporter of nuclear power plants beyond home markets. In the late 1980s, ABB purchased one of the U.S. reactor vendors-Combustion Engineering.

The second exception is the Soviet Union with its parallel efforts to develop nuclear power. Like the United States, it developed the LWR (called the VVER) which became the dominant type of Soviet nuclear power plant. The second type of reactor, a graphite moderated light water-cooled reactor called the RBMK, was built in significant numbers until the Chernobyl accident raised fundamental safety questions about this reactor type. In 
addition to LWR nuclear power plants, one other type of nuclear power plant received international acceptance-the Canadian CANDU heavy-water reactor. It was designed to meet specific Canadian conditions:

- It is fueled with natural uranium. It does not require enriched uranium or a complex nuclear fuel cycle. This was designed to take advantage of abundant uranium resources in Canada without the need to build a large nuclear fuel cycle support infrastructure.

- It is designed to be built without requiring a very large industrial base-specifically without requiring a sophisticated steel industry to supply large pressure vessels and other very specialized components.

The CANDU reactor has its own unique history and fills what must be considered a niche market for nuclear power.

\subsubsection{Changing Markets and Changing Vendors}

In 1973, the oil embargo fundamentally altered energy markets and set into motion market forces that restructured the nuclear power industry. In the United States, the rate of increase in electric demand dropped rapidly. From today's perspective, much of the reduction in rate of growth in electric demand would have occurred in any case due to saturation of markets for electricity-using durables. In addition, the oil embargo created a concern about energy shortages that encouraged energy efficiency. Ongoing utility power plant construction resulted in constructing excess electric generating capacity with the market for all types of new electric power plants disappearing. Since most electric power plants burn coal, there was not a strong incentive to replace existing electrical generating capacity. The U.S. nuclear power reactor vendors lost their home markets.

In Europe and Japan, electricity-using durable markets were not saturated. Most of the power plants burned oil and became very expensive to operate. There were massive economic incentives to build nuclear power stations. The European and Japanese vendors had begun to develop their own capabilities to design and construct nuclear power plants. These vendors rapidly expanded their development and engineering staffs to meet demand. The U.S. vendors received licensing payments but did not build the plants. The rate of construction of new nuclear power plants continued at a high level through the mid-1980s until the growth was slowed by a combination of saturation of electric demand, saturation of nuclear power in selected countries (France), and opposition to nuclear power.

Simultaneously, the former Soviet Union (FSU) began a major program for use of nuclear power. Two economic forces encouraged this development. First, most of the electric energy demand was in Eastern Europe and the western portions of the FSU while most of the fossil fuel resources were in Siberia. The high costs of transportation made nuclear power preferable in the western FSU. Second, high world oil prices created strong incentives to export oil for needed hard currency rather than buris the oil to produce electricity.

In the 1980s, the original technology licensing agreements between the United States and foreign vendors began to expire. The foreign licensees were now independent reactor 
vendors in competition with U.S. vendors. The foreign vendors had large facilities and experienced staffs due to the large number of nuclear power plants that were built in Europe and Japan. Most of the nuclear power plants built in the 1980s were built by these vendors. The growth of the European common market encouraged further consolidation of industrial groups in Europe, which strengthened these vendors.

\subsubsection{Historical Impacts of Nuclear Power on Traditional Vendor and Utility Structure}

Vendors and customers (utilities) in the worldwide electric power industry traditionally had a mix of private, public, and government ownership. The introduction of nuclear power has not significantly changed the nature of the ownership of the customers' organizations (i.e., those who generate and distribute electricity); however, it has had a significant impact on the ownerships of vendors in the industry. Those countries that historically had utility ownerships dominated by governments continued in this vein, while countries that had private and/or public utility structures (United States and Japan) have also continued with their structure.

Historically, the component, equipment, and construction companies in the industrialized countries have been privately owned companies, sometimes separate divisions of the utilities, but rarely, if ever, government owned. In Canada and France, the introduction of nuclear technology changed this fact. Atomic Energy of Canada, Ltd., (AECL) designs and builds systems as well as hardware; Framatome, the reactor designer and manufacturer in France, is primarily owned by the French government agencies Compagnie General d'Electricia (CGE) and Commissariat a l'Energie Atomique (CEA) along with the French utility Electricite de France (EdF), that is also owned by the French government. These developments have produced very large government-owned vendors who currently compete with private and/or publicly owned vendors in the world market. Consequently, publicly owned companies are changing their modes of operation to remain competitive. Some large privately owned companies, such as $\mathrm{ABB}$ and Siemens, have bought smaller nuclear vendors, while others, such as General Electric (GE) and Westinghouse (W), are developing numerous joint venture relationships. As discussed earlier (Sect. 2.2), there are very large economic advantages of scale if reactor development costs can be spread over many reactor sales. As a result of these evolutionary changes, the vendors and vendor groups competing in the international nuclear market can be separated into the following groups that have developed their own capabilities and/or licensed the use of technology and have bought companies with nuclear industry knowledge:

\section{(1) Government-owned companies,}

(2) Large corporations, and

(3) Keiretsu organizations (Japan) consisting of groups of related companies that own stock in each other.

The corporations in all of these groups participate in numerous joint ventures with each other and dominate many smaller suppliers, thus increasing their industrial base. This results 
in joint ventures that include vendors owned by governments, private investors, and keiretsu groups.

A dominant common characteristic of these groups and the joint ventures is the large financial strength that permits them to take large financial risks (Table S1). These groups and joint ventures have financial strength in one of the following forms-government backing, large corporate rescurces, or pooled resources through arrangements on R\&D and/or marketing programs. These organizational relationships are shown in Table 3.1 by listing the parent organization/group/corporation in Column 1, the reactor vendors and complementary corporations as subsidiaries, and placing other details in the balance of the table. It is interesting to note that the organizations in Column 1 include governments, utilities, keiretsu, and corporations. These are the organizations that emerge when the owners and/or industrial group relationships of the reactor vendor companies are identified. Appendix $\mathbf{A}$ provides detailed backup information.

\subsection{LOCAL RULES-TECHNICAL CONSTRAINTS}

It is obvious that those who write the rules have an advantage in any game or competition. All industrialized countries have their rules (codes, standards, regulations, laws, etc.). In all countries, the local rules used to protect the public from the failure of equipment are voluminous, complicated, and a product of the local legal systems. These local rules constitute a barrier to the international acceptance of industrial equipment that is not always visible or obvious. Often these rules create powerful incentives for the development of local partnerships and international enterprises.

The American Society of Mechanical Engineers' (ASME) Boiler and Pressure Vessel Code (B\&PV) emerged as a universally respected code for the design of pressurized components, equipment, and hardware for the power plant industry during the $20^{\text {th }}$ century. At the turn of the century, fatalities due to steam boiler explosion reached a deplorable level and resulted in the ASME developing the B\&PV code. The decline in boiler failures in the United States, due to improved designs that were developed in compliance with the B\&PV code, was dramatic and established the ASME B\&PV code as credible and potentially helpful code for many other countries. The code grew in stature and gained large international strength during the decades following World War II. International recognition was also attained by the codes of the American Institute of Electrical and Electronic Engineers (IEEE) and the American Society for Testing and Materials (ASTM). The requirements, rules, and guidance, developed by the U.S. Atomic Energy Commission (AEC) and subsequently the U.S. Nuclear Regulatory Commission (NRC), have been used as the base requirements or guidance by many foreign nations and world organizations. For decades, U.S. industry has written the rules that dominated the design and acceptance of pressure vessels, piping, nuclear hardware, and electrical equipment while many countries either used U.S. codes or slightly modified versions. This recognition and/or strength of U.S. codes and standards was probably due to:

- the strength of the U.S. economy during those decades; 


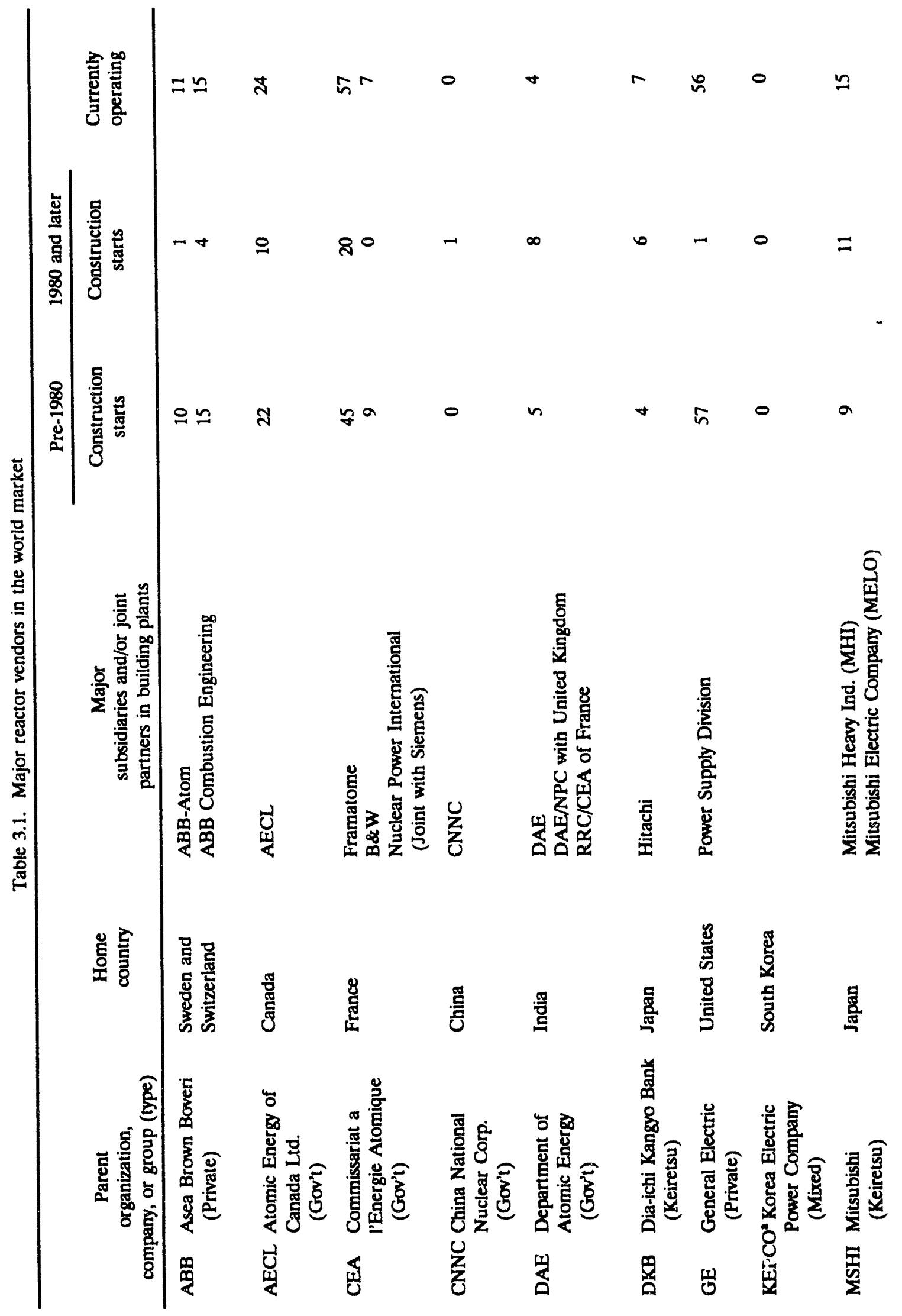




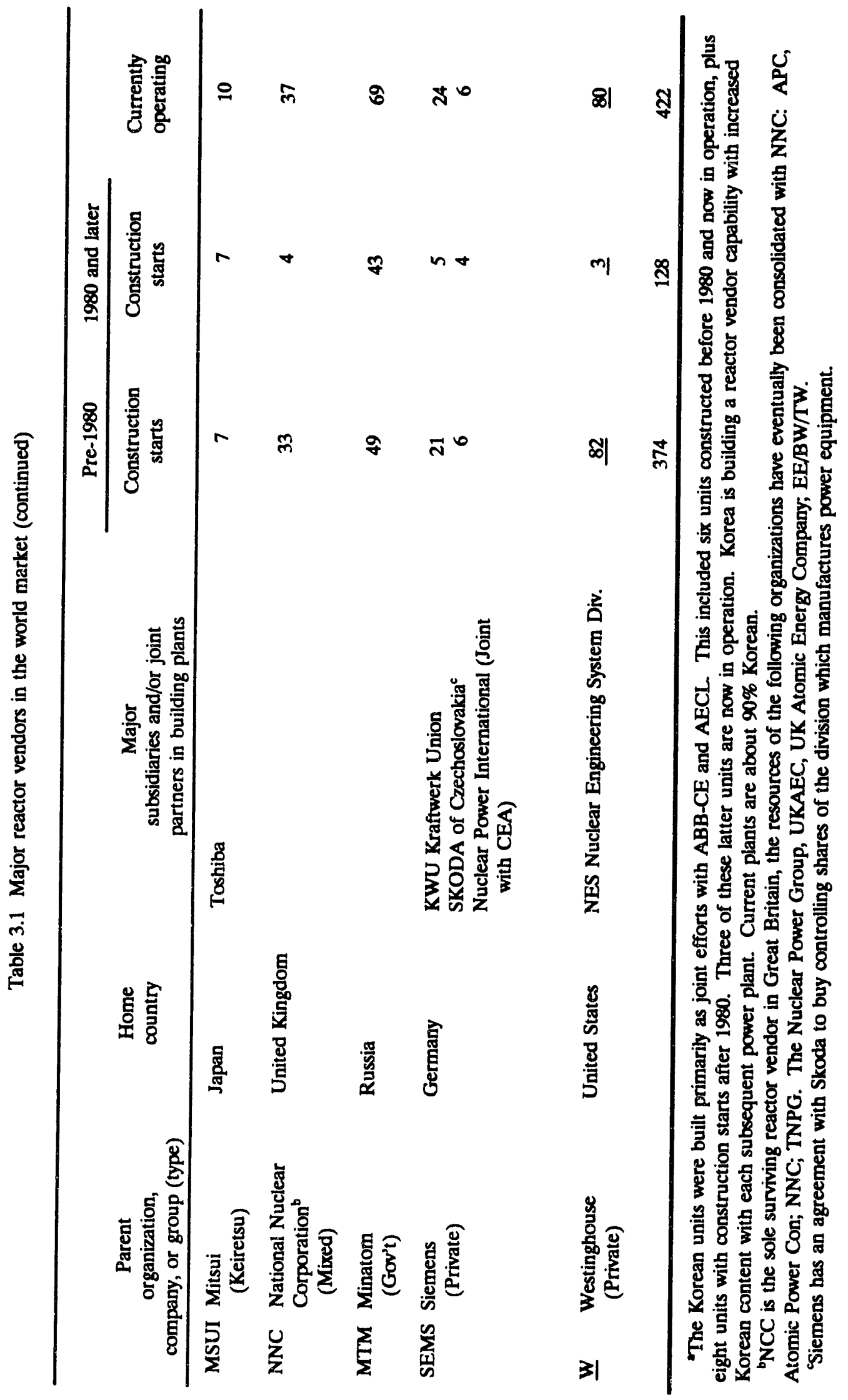


- the quality of the engineering content, the amount of industrial support for the code/standards committee work, and the recognition of the relatively open consensus approach to code development; ${ }^{*}$ and

- customers' (throughout the world) desire for U.S. products and engineering during a period when they were developing and/or rebuilding their economies and industries.

All countries cannot expect to have unique codes; however, the European Community and the Japanese seem to see merit in separating their codes from the U.S. codes. Europe and Japan are funding programs that encourage developing countries to develop standards that fit the standards of Europe or Japan (i.e., the countries that are providing the funds for their laboratories). Simultaneously, there is a major effort in Europe to create unified European nuclear standards. An example of this type of activity can be seen by the work of Nuclear Power International (NPI), the joint venture of Framatome and Siemens to design, develop, license, and construct the next generation LWRs for Europe. As a part of this effort, they are agreeing on when and how to integrate French, German, and other codes/standards. The European Fast Reactor (EFR) group is another example of a similar effort.

\subsection{INFLUENCE ON VENDOR DEVELOPMENT}

\subsubsection{Complications and Conditions in the Market}

Vendors, constraints, and customers in the pre-1960 market vs today's market are shown in Fig. 3.1. The number of vendors has increased, the number of customers has increased, and the complications due to new rules, regulations, and international organizations have increased. The comparisons shown in Fig. 3.1 give an indication of the growth of the industry and the associated complications that have developed during the last few decades. Fig. 3.1 only includes a part of the industry's total picture, only major reactor vendors (RVs) and some architect engineering (AEs) companies are included. The long list of component, equipment, and fuel suppliers is not included. Additionally, only the most visible constraining codes, standards, regulations, and international organizations have been identified and only the types of customers have been noted. The size and complications of the market can be appreciated when it is recognized that smaller suppliers and some countries' additional detailed regulations are not even included on this list, while the general categories of customers listed exist in over 30 countries.

The implications of this evolution is the decentralization of decisionmaking with no company or country having dominance over the industry. It also implies that typical vendors have less influence over customers because there are more alternative suppliers with the prerequisite technical and financial capabilities. This evolution further indicates that governments or very large corporations not currently in the nuclear power business can enter the business since the technology is generally available. The emerging South Korean vendor is an example of this.

(The committee members were respected technical people who contributed their time

as well as their employer's time and acted as technical professionals working to satisfy "society's needs" without commitment to particular company desires.) 


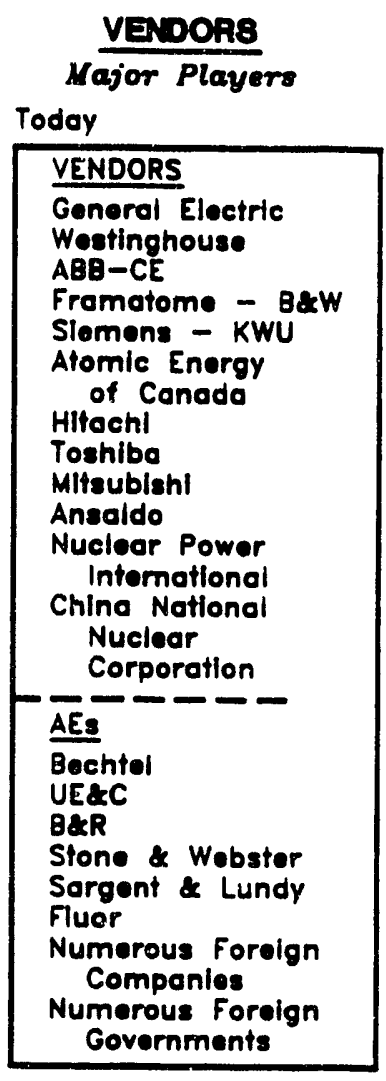

Pro-1960

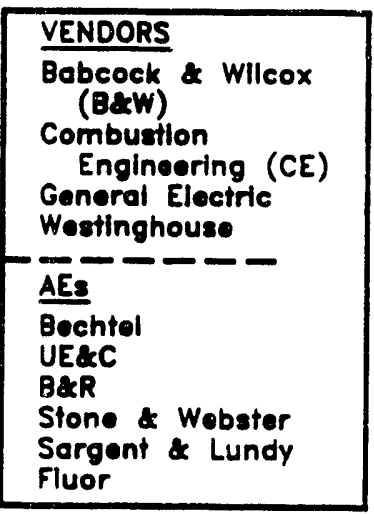

\section{CODE8 \& 8TANDARDS}

Today

ASME B\&PV SECTION
III \& IX
(for nucleor equipment)
ASME B\&PV (for
Prossure equipment)
ASTM Standords
IEEE Standards
ISA Standards
RCC-M - French Code
CODAP - Fronch Code
TRD - Germon Code
TRB - Gormon Codo
JIS - Joponese
BSI Standard Instlitute
- British
Similar codor in other
countries

Pre-1960

ASME B\&PV (for
pressure equipment)
ASTM Stondards
IEEE Standards
ISA Standards
Bullding Codes
BSI-U.K.

\section{REGULATIONB}

Today

NRC - U.S.
Regulations
Guldes
CFR - U.S.
MITI - Jopan
- French
- Germon

Pre-1960
$\begin{aligned} & \text { AEC } \\ & \text { Dovelopment of Rules } \\ & \text { CFR } \\ & \text { Dovelopment Code } \\ & \text { for Nuclear }\end{aligned}$
NTIENATONAL
ORCANIATION
TodoY
OECD - NEA
IAEA -
WANO -

ORNL DWG 92A-667R CUSTOM JRS Major Playero Today

\begin{tabular}{|l|}
\hline - Utillies \\
- Oistribution \\
Companies \\
- Power Companies \\
- Industrial Groups \\
- EPRI \\
- USCEA \\
- Governments \\
- Ministries of \\
Enorgy, Trade, \\
and Finance \\
- All of the above \\
now exist in about \\
35 countries
\end{tabular}

Pre-1960

Utilities and governments in a fow industrialized and politically credible countites

Fig. 3.1. Vendors, constraining rules, regulations, organizations, and customers 


\subsubsection{Vendor-Utility Relationships}

The evolution of the market has resulted in the development of three types of vendor customer relationships.

1. The permanent relationship that develops between government agencies and/or departments. France, Canada, Russia, and China work with this type of relationship between their government-owned vendors and government-owned utilities. In France and Canada, the vendor structure also includes private groups.

The relationship of a government-owned vendor and utility often extends beyond the domestic market to international sales. An example is France (Taylor 1992a). In France, the vendor Framatome supplies the nuclear reactor system, while the French government-owned utility EdF acts as the project manager and is the $\mathrm{AE}$ for the rest of the plant. In foreign sales, the utility is often a partner with the reactor vendor. For example, France sold the two-unit Guangdong nuclear power plant that will begin operations in 1993 to the Peoples Republic of China. While Framatome provided the nuclear power reactor system, EdF is the technical project manager. EdF is also providing training in operations and maintenance to the Chinese staff.

2. Long-term relationships develop between the people in large companies and the people in their large and old established customers. Siemens, ABB, and Japanese companies seem to focus on this approach, which effectively uses their established business relationships that have been developed with the customers through their nonnuclear businesses. This is common in Japan and Europe.

This relationship is seen particularly in Japan, where long established relationships have a major impact on the strategic decisions that are made in the government organizations, utilities, and vendor companies. Traditionally, each Japanese utility buys from one or two specific vendors. These decisions are based on technical evaluations, political factors, and business linkages. Nontechnical factors are important to the consensus that is usually essential for actions or decisions in the Japanese organizations. Political and business thinking is complex and significantly influenced by the Japanese implementation of two concepts. Information flows through a "gakubatsu" (i.e., a club whose members are graduates of the same university) and business is usually conducted with members of a "zaibatsu" (i.e., a family of organizations usually headed by a major financial organization or bank that maintains a protective overview of its members). Keiretsu groups are a current form of the zaibatsu families that started before the 20th century.

The influence exerted by members of a gakubatsu has a major impact on government, corporate, and utility decisions relative to the ordering of power plants in Japan. Information flows at all levels in these organizations and is significant in the development of national policy, corporate strategies, utility planning, and the selection of vendors. This type of integrated thinking can be very frustrating to the vendor, who is not privy to the gakubatsu communications. 
3. The business relationships that develop between customers and their vendors when there are numerous vendors who provide competitive bids for design, fabrication, and/or construction on large projects. This individualistic, competitive approach is common in the U.S. vendor and utility selection process.

The typical U.S. vendor-utility relationship may have contributed to the development of Electric Power Research Institute (EPRI) and several other organizations in the United States that do not have analogous organizations in most other countries of the world. EPRI is the electric utility's research organization that addresses problems that are common to U.S. utilities. (EPRI performs the coordinating R\&D functions needed by many of the utility companies in the United States). To some extent, EPRI addresses issues that pertain to foreign vendor utility interactions. For example, EPRI has recently completed its work on developing the requirements for large LWRs [1200 MW(e)] that satisfy the future large plant needs, otherwise known as "the evolutionary LWR." EPRI has also completed work on smaller passive-design LWR requirements known as "the advanced LWR," that will cover the market for smaller plants [600 $\mathrm{Mw}(\mathrm{e})]$. These documents are used when utilities discuss future power reactor purchases with vendors. In contrast, in Europe, the French utility, EdF, and the German association of nuclear utilities (EVU) have formed a joint committee (NNb 1992) with their long-term vendors on requirements for the European pressurized-water reactor (EPR).

Most of the vendors, who typically work or sell in one of these vendor-utility relationships, also want to sell to customers who are most familiar with another vendor-utility relationship. Therefore, they (the vendors) must recognize the differences and modify their business approaches if they expect to have successful long-term relationships in the new markets. The changes may be required to satisfy differences in cultures, customs, laws, specifications, codes, standards, and/or pricing structures. The flexibility of the vendors will probably have a major influence on their success. This flexibility will reflect their companies' restraints, their countries' laws, and the ability of their people to work effectively in, and with, these different vendor utility relationships. In some instances, it is convenient or necessary to have joint ventures in order to penetrate the markets.

The present and future international nuclear power reactor market appears to expect, and may flourish on, a comprehensive and long-term reactor vendor and plant operator relationship (i.e., more than reactor vendors have provided to the U.S. utilities over the past few decades). This change appears to be a consequence of the increased safety requirements and complexity of modern plants, which require many more types of specialists to maintain the plant. Such experts are not required full time for a single plant. This is similar to the aircraft and mainframe computer business, where vendors supply their expertise. The time and other resources required to familiarize a new supplier with current plant design/conditions creates strong incentives for long-term utility-supplier partnerships. The historical U.S. vendor-utility arrangement protects the independence and free competition for architect-engineers, builders, reactor manufacturers, and nuclear service companies; however, it may not provide the integrated design, build, and support responsibility that will be expected by the international market of the $21^{\text {st }}$ century. 


\subsubsection{Scope of Vendor Responsibility}

The customer ultimately determines the vendor's scope of responsibility. Construction of a nuclear power plant involves many activities: (1) design/fabrication of the nuclear reactor system that produces steam, (2) design/fabrication of the turbine/generator to produce electricity from the steam, (3) AE activities to integrate various systems together and design buildings, (4) construction of the plant, (5) startup/maintenance operations, and (6) other activities. Different utilities around the world have preferred different approaches for managing power plant projects. Some purchase the nuclear systems and perform the architect, engineering, and construction work with their own people (Duke Power in the United States and EdF in France), while others contract for various combinations of design, construction, support services, or (in some instances) the whole package. Reactor vendors also have approaches that they prefer and promote:

- Siemens advocates "turn-key" contracts where they design, build, and operate the entire plant for the first year before turning over the total facility to the ultimate owner. They have their own AE, construction, component, and system organizations including design, fabrication, operation, and maintenance people.

- Framatome usually delivers nuclear reactor systems, components, and services as part of a team effort, primarily with other organizations that are also owned by the French Government. The Japanese vendors have adopted a somewhat similar approach where the same private companies work together on multiple power plants.

- General Electric and Westinghouse deliver reactors with a variety of contractual arrangements with responsibilities shared between $\mathrm{AE}$, constructors, and Nuclear Island suppliers. The AEs, constructors, and nuclear equipment/system suppliers are often independent companies that compete for the various segments of the plant work.

These approaches have developed as a response to the regional customers and as a result of the periods when the various companies entered the market.

How the customers' needs are satisfied reflect government policies, local customs, and regional business characteristics. Framatome supplies all the reactor plants for EdF, its parent government organization which supplies $90 \%$ of France's electricity. Mitsubishi has supplied all PWR power plants for particular Japanese utilities. These close reactor vendor and customer relationships are more involved and supportive of the customers' total need than the relationships that often exist between the utilities and reactor vendors in the United States.

In many countries AEs and construction companies are part of the vendor or utility parent organizations. KWU is the construction arm of Siemens. EdF, the French utility, does its own $\mathrm{AE}$ and construction work and partly owns Framatome. Mitsubishi Heavy Industries does the AE and construction work for Mitsubishi Electric Corporation.

The U.S. reactor vendors have been more restricted in the scopes of work they perform prior to the plant operation (i.e., they don't do the AE and construction work), and they do not 
automatically provide the degree of involvement with the plant operators that is commonly provided by their international competitors. The foreign organizations with their broad scopes often project a very protective/responsible feeling about the overall operation of the plants they build. This often includes large corporate staffs permanently in residence at the utilities' plants, as is common in France, Japan, and Germany. This also provides the vendor with a better understanding of utility needs which provides a competitive advantage in future work to the vendor.

\subsection{VARIOUS VENDOR BUSINESS STRUCTURES}

The dominant characteristic of nuclear power in terms of business structure is that a single nuclear power plant may cost several billion dollars. The large cost of a single unit implies that reactor vendors must have large financial resources and large organizations to build such facilities. The organization of the industry worldwide reflects this reality.

\subsubsection{Parent Corporate Structures}

As discussed previously, the evolution of reactor vendors resulted in government-owned companies, large privately owned corporations, and keiretsu companies. These organizations evolved as a result of the local customs/conditions as well as the market demand.

\subsubsection{Government-Owned Vendors}

In France, China, Russia, India, and Canada, the governments made clear decisions regarding the countries' need to (1) use nuclear power and (2) establish government controlled reactor vendors. National policies were adopted with plans and schedules that were implemented and followed.

Framatome is currently a major reactor vendor in the world market place and a classic example of a government-owned reactor vendor. The French Government owns most of the French nuclear industry, including the utility (EdF), the reactor manufacturer Framatome (which also owns the previous U.S. manufacturer B\&W), the nuclear fuel supplier (Cogema), and numerous small, but very competent, suppliers. This combination of companies has vertical and horizontal integration. It combines the government, utility, hardware suppliers, and waste management organizations for vertical integration. This combination also has multiple reactor hardware suppliers, multiple fuel suppliers, and all French nuclear power stations for horizontal integration. AECL of Canada is another example of a governmentowned vendor with similar relationships, but inclusion of more private companies as partners or suppliers.

\subsubsection{Large Corporation Vendors}

$\mathrm{ABB}$ is a classic example of a large corporation (210,000 employees) competing as a nuclear power reactor supplier in the world market who owns reactor vendors in multiple countries. In 1988, Asea of Sweden and Brown Boveri of Switzerland (two intensely competitive worldclass industrial corporations) joined forces to form $\mathrm{ABB} ; 50 \%$ owned by Asea traded on the Swedish stock exchange and 50\% owned by Brown Boveri traded on the Swiss stock 
exchange. Asea was known for its management talent, reactor designs, and numerous industrial products sold throughout the world. Brown Boveri was known for its manufacturing expertise and numerous industrial products sold throughout the world. In 1990, ABB acquired control of Combustion Engineering, a U.S. supplier of nuclear reactors that sold plants in the United States and throughout the world. This combination of engineering talents, manufacturing capabilities, large financial resources, and international marketing organizations constitute a very formidable competitor.

Siemens and General Electric are even larger reactor vendor corporations, both with over 300,000 corporate employees. Siemens owns Kraftwerk Union (the German reactor manufacturer) and is buying Skoda, the Czechoslovakian reactor manufacturer. Westinghouse, while the smallest of the large corporation vendors $(120,000$ corporate employees), has built the largest number of reactor plants, however, it has not sold a significant numicr of plants in the last decade.

\subsubsection{Keiretsu Vendors}

The Japanese reactor suppliers (Hitachi, Mitsubishi, and Toshiba) are each large companies, but more importantly, they are members of industrial groups with very large resources. These groups - Dai-ichi Kangyo Bank (Hitachi's group), Mitsubishi, and Mitsui Taiyo Kobe (Toshiba's group)-are each linked to about a dozen major companies and hundreds of small companies. Each of these vendors also ha: close relationships with particular Japanese utilities.

The keiretsu organizations in Japan and similar organizational structures in other Pacific Rim countries are somewhat different than traditionally managed (top-down) U.S. or European corporations. In a keiretsu, each member corporation is a major stockholder in other companies that are part of the same group. If a member of the group has financial or management difficulties, the group as a whole can provide financial support or force change in management of a specific corporatic $\eta$. Keiretsu has been developed as a mechanism to allow creation of very large groups while avoiding the difficulties of organizational rigidity and slowness in adapting to technological change.

The advantage that a vendor has as a member of a keiretsu cannot be underestimated by a competitive vendor who expects to sell in the same market. Effectively, the member of the keiretsu has the depth of resources owned by all members. Financially, each member can obtain funds at attractive interest rates with little or no concern about having sufficient collateral. Technically, each member also has access to engineering information from other members of the family. These Japanese groups are huge networks (annual sales of hundreds of billions of dollars) that can disperse the financial risks associated with business ventures to many companies that may $n\lrcorner t$ even have the sane product lines or sell in the same markets.

\subsubsection{Joint Ventures}

All of the major vendors (except those in Russia) are currently participating in various forms of joint ventures with other reactor vendors, $\mathrm{AE}$ companies, and construction firms. These 
joint ventures serve many purposes, including the sharing of financial risks, R\&D cost, and introduction into new markets.

The European company "Nuclear Power International" is a joint venture of Framatome, EdF, and Siemens aimed at designing, developing, and building the next generation of European LWRs.

General Electric, Hitachi, and Toshiba have joined forces and are currently building a large advanced BWR in Japan. Westinghouse and Mitsubishi are currently working on the design of the advanced pressurized water reactor, which is expected to be the next PWR to be built in Japan. Westinghouse and National Nuclear Corporation are currently building the first large PWR in the United Kingdom. ABB-CE is building reactors with and/or for the Korean Electric Power Company (KEPCO). Atomic Energy of Canada Limited has a similar arrangement with South Korea.

The major nuclear reactor design and development programs all over the world are joint ventures between various combinations of government-owned companies, large corporations, and corporations that are part of keiretsu groups. The bulk of the current market is being served by combinations of companies as compared with the initial nuclear market (1950s and 1960 s) that was served by individual reactor vendors. These ongoing projects typically have broad vendor scopes with characteristics of the "turnkey contracts."

\subsubsection{Vendor Business Structures}

Table 3.1 shows parent organizations and reactor vendor corporations. The strength of the ties to the financial depth of parent organizations is the key to the financial risk that can be taken by a reactor vendor. The ability of the joint venture associations to use or count on the resources of their partners is, at times, nebulous. However, the resources of the large corporations and the government-owned corporations are real and very visible. Whether significant funds for commitment are available for the reactor vendors is another question that is usually resolved in the final contractual details. Often, the initial perception of large government or corporate financial strength and depth is sufficient to provide the needed competitive advantage.

The remaining independent U.S. reactor vendors-General Electric and Westinghouse-are similar to the European large corporations and Japanese keiretsu corporation groups, while the other U.S. reactor vendors-Combustion Engineering and Babcock and Wilcox-have been acquired by $\mathrm{ABB}$ and Framatome, respectively. Parent organizations in the nuclear power reactor industry are becoming the major players as much as the individual reactor vendor corporations.

The competitive positions of different reactor vendors or different countries depend upon multiple factors:

(1) number of nuclear power reactors being built in the home markets,

(2) number of nuclear power reactors operating in home markets that require maintenance, fuel, and other services, 
(3) the size of reactor vendor,

(4) the size of parent corporation,

(5) the national support of related R\&D activities/facilities,

(6) the industrial standards for equipment and operations, and

(7) the university structure to provide trained personnel.

Before the mid-1970s, the United States dominated each of the above categories, thus, U.S. vendors (primarily Westinghouse and General Electric) were the major vendors in the world. Today, the United States has the largest number of operating power plants and the largest university systems. Since the 1970s, how vver, most new reactors have been built in Europe or Japan. France and Japan have built very large nationally supported R\&D programs. Furthermore, Japanese business groups organizations are typically larger than their U.S. counterparts, while the French reactor vendor is owned by the government. Last, the development of the European Common Market is creating an industrial market sufficiently large (i.e., larger than the U.S.) for development of standards and regulations. These standards are competing with U.S. standards for world acceptance. For any vendor, it is much easier to design to home standards than foreign standards. The net result of these changes is that the European and Japanese vendors have become the largest nuclear power reactor vendors.

Simultaneously, to reduce business risk and expand markets, all major corporations in the business (with the exception of the Russian vendors) have formed international joint ventures or equivalent business structures. 


\section{DESCRIPTION OF PRODUCTS}

\subsection{INTRODUCTION}

The design of existing and future nuclear reactor products is driven by the needs of the utility customer within the constraints of vendor capabilities. The purpose of this section is to provide a brief description of the nuclear reactor products in terms of the markets the products serve. Detailed technical information on the products is given in Appendix B.

\subsection{DESIGN OBJECTTVES}

The design objectives of a particular reactor product are determined by the requirements of the product users. These user requirements provide the incentives for the development of a reactor design. The four broad categories of user requirements are briefly described beluw: (1) economic requirements, (2) operational/infrastructure requirements, (3) safety/public acceptance requirements, and (4) regulatory requirements.

\subsubsection{Economic Requirements}

Vendors marketing nuclear power plants must consider what competitive energy resources are available to a particular customer (e.g., coal, oil, gas, hydro, etc.). The distribution of a country's energy resources will be a major determining factor of the demand for nuclear power. A country with an abundant source of nonnuclear energy is unlikely to invest heavily in the development of a nuclear power plant. The distribution of energy resources by country is more fully described in Sect. 5.2.

Different nuclear reactor designs will have variability in such economic factors as plant design life, construction time, construction costs, fuel costs, and operating and maintenance costs. Historically, nuclear reactors have been designed to take advantage of economies of scale with large reactors being built in well-developed countries but having a limited market in smaller, less-developed countries. The large size of most nuclear reactors has restricted their use to countries with larger electric grids or rapid growth in electrical demand.

Some vendors have attempted to open new markets by developing smaller reactor designs that are still economically competitive. These vendors believe that cost reduction is achievable through plant design simplification. Significant cost reductions may be realized by simplifying safety systems and reducing the number of active safety system components.

The financing of a nuclear power plant is similar to a hydroelectric facility but different than fossil-fueled facilities. In comparison to fossil-fuel plants, the capital costs of a nuclear power plant are higher but the fuel costs are significantly lower. Thus, a customer must be able to bear the initial capital expenditures in order to reap the long-term benefits of lower operating costs. The capital-intensive nature of nuclear power, along with lower operating costs, make nuclear attractive for base load plants as opposed to load-following plants. The availability of capital will, in part, determine the demand for nuclear power. 


\subsubsection{Operational/Infrastructure Requirements}

A number of operational requirements affect the choice of power plant and its characteristics. The size and strength of the electrical grid determines the maximum size of the power plant. Nuclear power plants must be refueled, require routine maintenance, and occasionally shut down due to equipment failure. Typically, if an electrical grid suddenly loses more than about $10 \%$ of its electric generating capacity, there is a significant possibility that the electric grid will fail with loss of power to all customers. For this reason, utilities typically do not order power plants with generating capacities exceeding $10 \%$ of their total needs.

Larger utilities with more expansive electrical grids generally prefer a large power reactor. Small- and medium-sized power reactors generally appeal to smaller utilities or a utility that is replacing a fossil-fuel plant with a nuclear plant since fossil plants tend to be smaller in size than their nuclear counterparts.

Some electric grids have special requirements that limit the choice of power plants. For example, in the Nordic grid (Norway, Sweden) much of the electric power is generated by hydroelectric plants in the far north while the population centers are in the south. A major concern is the reliability of the grid and the potential for electric grid failure due to winter storms. Because of the cold climate, very high reliability of the electric grid is required. If the grid fails due to a winter storm, it is required that the fossil and nuclear power stations be restarted rapidly to provide essential electricity while the power lines to the north are repaired. This grid requirement is reflected in some of the unique technical characteristics of ABB BWRs and limits the choices of reactors for this region. Other countries have other specific grid requirements that impact the product requirements.

Infrastructure requirements include the compatibility of any future reactor with existing reactors. There are economic benefits if existing operational experience and equipment can be shared among reactors. Utilities who buy a single reactor from a particular vendor will prefer to buy similar reactors from the same vendor in the future if other factors are equal. Another infrastructure consideration is the need for support facilities to supply the reactors with fuel and equipment. Support facilities to supply enriched fuel would be costly to design and build, if not already available, or alternatively, the product user would have to rely upon another supplier for the fuel. Reactors that use natural uranium fuel, such as CANDU, are more attractive to users that are not willing to depend on foreign fuel suppliers and not able or willing to build uranium enrichment facilities.

\subsubsection{Safety/Public Acceptance Requirements}

Safety requirements must be addressed in order to ensure safe operation of the reactor and to enhance public acceptance of the design. In countries with few power reactors, the utility and/or national regulator usually requires that purchased reactors be "licensable" in the country of origin with modifications for local conditions.

Several vendors, as a product development strategy, are designing future reactor products with safety characteristics to simplify licensing and improve public acceptance. In this 
context, the reactor industry is taking steps similar to certain automobile manufacturers (such as Volvo) that use safety features to increase sales.

The term "design type" is used to categorize reactor designs based on their safety characteristics. Existing and proposed reactor designs can be divided into four design types: evolutionary plant reactors, evolutionary technology reactors, liquid-metal breeder reactors, and PRIME reactors. A more detailed description of these reactor design types and the associated safety systems can be found elsewhere (Forsberg 1991).

Evolutionary plant (E. P.) reactors are similar in overall plant design to existing LWRs or CANDU reactors but have refined and modernized design. Safety of E. P. reactors depends on a variety of active safety systems with power supplied by diesel generators or equivalent power sources. In the event of an accident, the safety systems must start up and continue to operate in order to prevent reactor core damage.

Evolutionary technology (E. T.) reactors are proposed advanced reactors that use the technology of current reactors but have significant changes in plant design, particularly in the safety systems. Most of the proposed safety systems for these reactors require power to initiate safety operations (such as opening a valve) but do not require power for continued operation. Safety system operation after initiation is passive. Vendors expect such reactors to be more economical than evolutionary plant designs in smaller sizes [600 MW(e)], thus increasing the number of utilities that could buy nuclear power plants. Improvement in safety with easier operation is also expected. Multiple vendors are developing such plants including Westinghouse (AP-600), Mitsubishi (MS-600) and General Electric (SBWR) for sale in the mid-1990s.

PRIME reactors are proposed where the design goals are to make radical improvements in safety and public acceptance (not dependant on operator for safety, etc.) with the potential for major improvements in economics. The vendor interest is to develop a unique product with greater public acceptance, which would translate into a unique competitive advantage (nuclear power equivalent to development of jet engine or transistor). Because the goals are aggressive, new technologies are required for the reactor designs. The term, PRIME, provides a reasonable description of these goals. PRIME is an acronym for passive safety, resilient operation, inherent safety, malevolence resistance, and extended safety. The PRIME reactor closest to commercialization is the PIUS reactor of $\mathrm{ABB}$. Commercialization is not expected before the late $1990 \mathrm{~s}$.

Breeder reactors, of which the dominant type is the liquid-metal reactor (LMR), convert cheap, fertile, nonfuel materials (such as ${ }^{238} \mathrm{U}$ ) into valuable fissile fuels (such as ${ }^{239} \mathrm{Pu}$ ). This would lower fuel costs. Earlier LMR prototype plants and designs relied upon active safety systems. Newer breeder reactor designs, such as the Power Reactor Inherently Safe Module (PRISM ${ }^{\circ}$ ), depend primarily on passive safety systems. These reactors are a long-term nuclear power option under development by national governments and are not near-term commercial products. Low uranium prices have reduced the economic incentives to develop such reactors. 


\subsubsection{Regulatory Requirements}

Nations regulate nuclear power to ensure safety. Different technical, economic, and cultural factors result in significant differences in regulations across national boundaries. Regulations define minimum standards for safety. Vendors and utilities may exceed regulatory minimums to minimize financial risk, improve public acceptance, meet corporate philosophies, or improve operability. This variation, in turn, implies that some details of a particular reactor design will change depending upon where it is built. The following examples illustrate this fact.

- In Japan, very tight regulatory requirements exist to ensure reactor safety in the event of an earthquake. In Germany, power reactors must have containment buildings that can withstand the crash of a military jet. Such requirements reflect local technical safety issues. Earthquakes are common in Japan and are a potential cause of a nuclear power plant accident. During the cold war, the highest density of military aircraft in the world operated over Germany, thus, the heightened (and real) technical concern about possible crashes of military aircraft.

- Levels of safety vary from country to country depending upon local economic conditions and cultural beliefs. These cultural factors can influence regulations. For example, some countries have long traditions in the use of concrete or steel. In such countries, particular materials of construction for buildings are preferred because the regulator is technically more knowledgeable and has higher confidence in the use of the materials. Regulations may impose much higher safety margins for technologies and materials with which the regulator is unfamiliar.

\subsection{PRODUCT DESCRIPTIONS}

A summary of general product characteristics and the markets they serve is given in Table 4.1. The products are listed in alphabetical order by product name. The five reactor types listed are BWR, pressurized-water reactor (PWR), HWR, liquid-metal fast breeder reactor (LMFBR), and high temperature gas-cooled reactor (HTGR). The design type of a product is based on the functional characteristics of the reactor safety systems as described in Sect. 4.2.3.

The developmental status indicates the degree of commercial development as follows.

- In-use

- Design

- Research
A commercial reactor of this design is currently operating.

Construction of this reactor design is currently taking place in one or more locations.

Research and development has advanced into the design of the reactor concept.

Preliminary studies to evaluate the feasibility of the reactor design have begun.

Conceptual idea.

The availability indicates when the particular reactor product will be available to o.der from the vendor. 


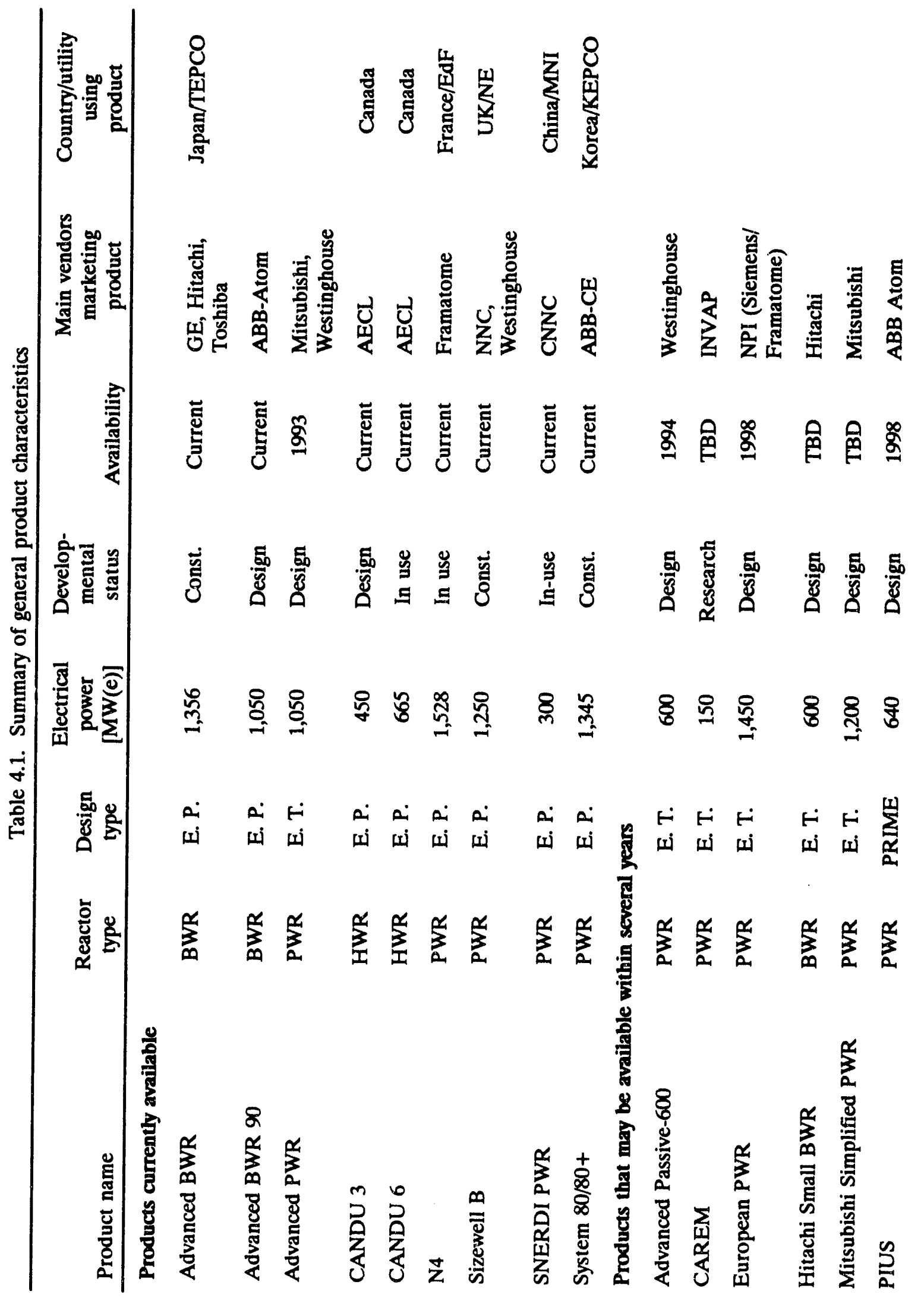




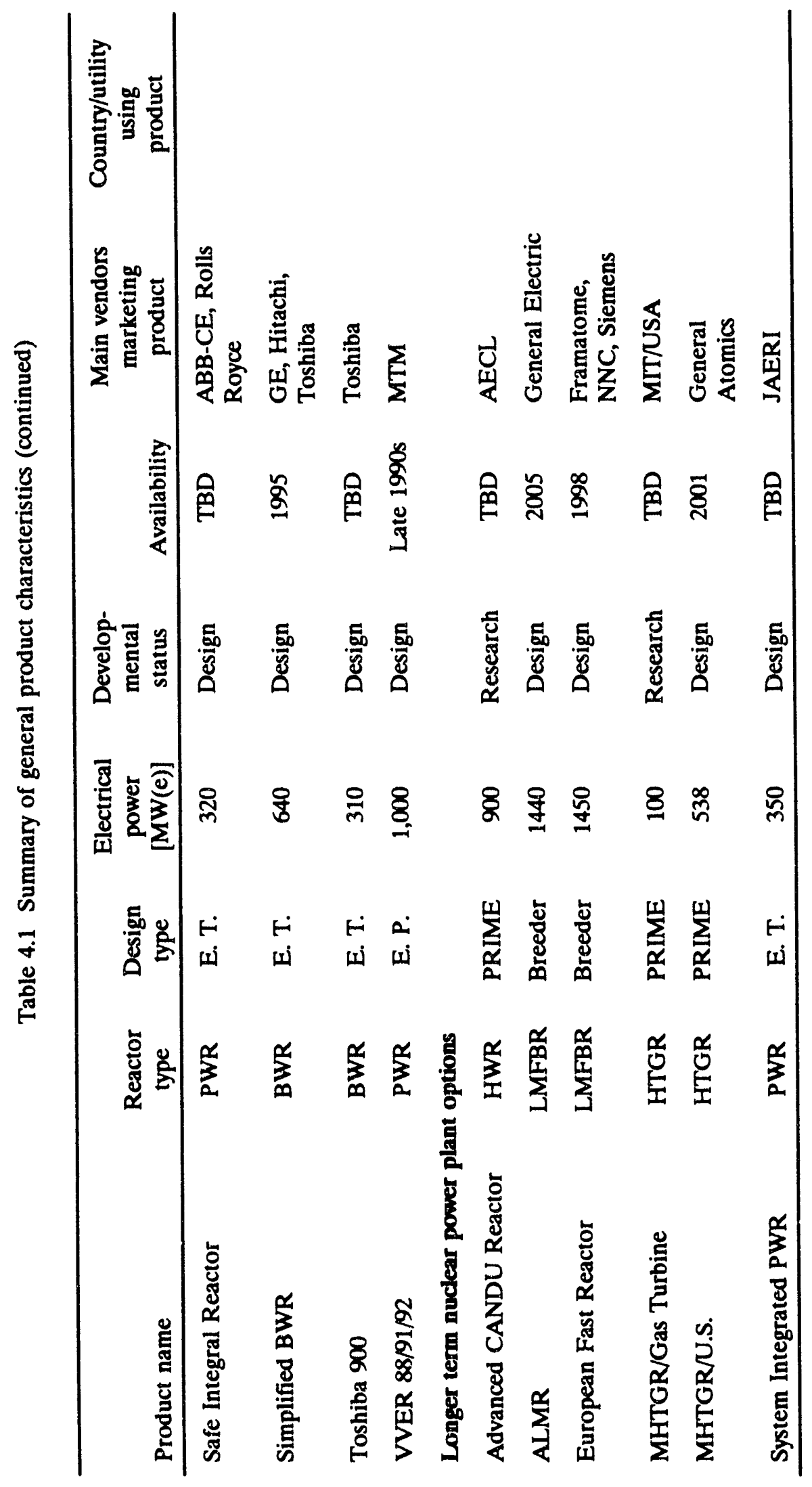




\section{THE CUSTOMER SIDE OF THE MARKET}

Electric utilities, the customer side of the nuclear power reactor market, are discussed in this section. Because of the large number of utilities throughout the world, the discussion is initially at the country (rather than individual utility) level. Nuclear-related decisionmaking in countries with different numbers of utilities is compared.

A screening process, described in more detail in the next section, was used to categorize each country as one of three types: (1) those that do not presently have nuclear power reactors and are not expected to develop nuclear capability due to restraining factors ( 72 nonnuclear countries); (2) those that do not presently have nuclear power reactors, but are potential candidates over the medium term ( 25 candidate countries); and (3) those that presently have operating commercial nuclear power plants or have such plants under construction (28 nuclear countries).

The screening process began by choosing 125 countries having a population greater than 1 million. Section 5.1 describes the initial screening process based upon electrical demand and total income for each country. In Sect. 5.2, the number of candidate countries is reduced even further by discussing factors that make the nuclear option unattractive to policymakers in many countries. In the final section, the decisionmaking processes for candidate and nuclear countries are compared.

\subsection{INITIAL SCREENING OF COUNTRIES}

Ideally, one would like to examine the characteristics of all existing and potential customers of commercial nuclear reactors (i.e., electric utilities). Practically, of course, such an examination is not possible, and, even if it were, it is probably not necessary. Many countries (and, therefore, electric utilities) do not currently have sufficient electric demand or total income to justify construction of nuclear power plants.

The most obvious countries are eliminated in Table C.1 in Appendix C. The table lists 125 countries in the world classified into four income categories that the World Bank uses to characterize countries: (1) low income economies (i.e., \$610 per year or less, 43 economies), (2) lower middle income economies, (3) upper middle income economies, and (4) high income economies ( $\$ 7,620$ per year or more, 24 economies). Along with three other socioeconomic measures, the table includes the existing nuclear power reactors and their capacities and the corresponding amounts for reactors under construction.

From this table, it can be concluded that a candidate country is one that currently does not operate nuclear power plants and had a total income (i.e., GNP) of at least $\$ 30$ billion in 1990. The $\$ 30$ billion threshold was selected because, with the exception of Bulgaria, it is the lowest total income of any of the countries currently operating or constructing nuclear power plants. In Table 5.1, the candidate countries are the ones that do not have existing nuclear capacity or do not have any nuclear power plants under construction in those respective columns under the category, "Generating capacity." 


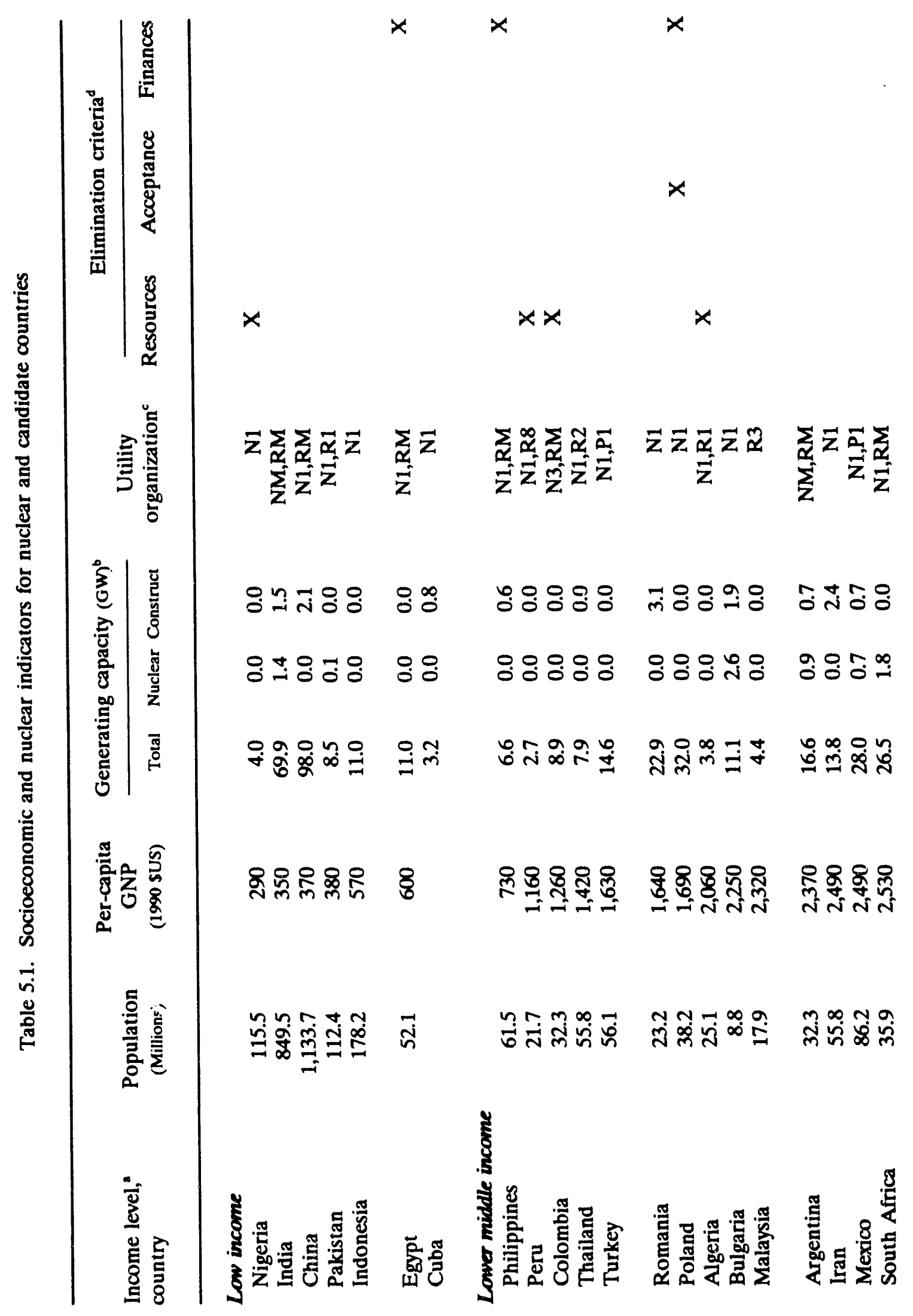




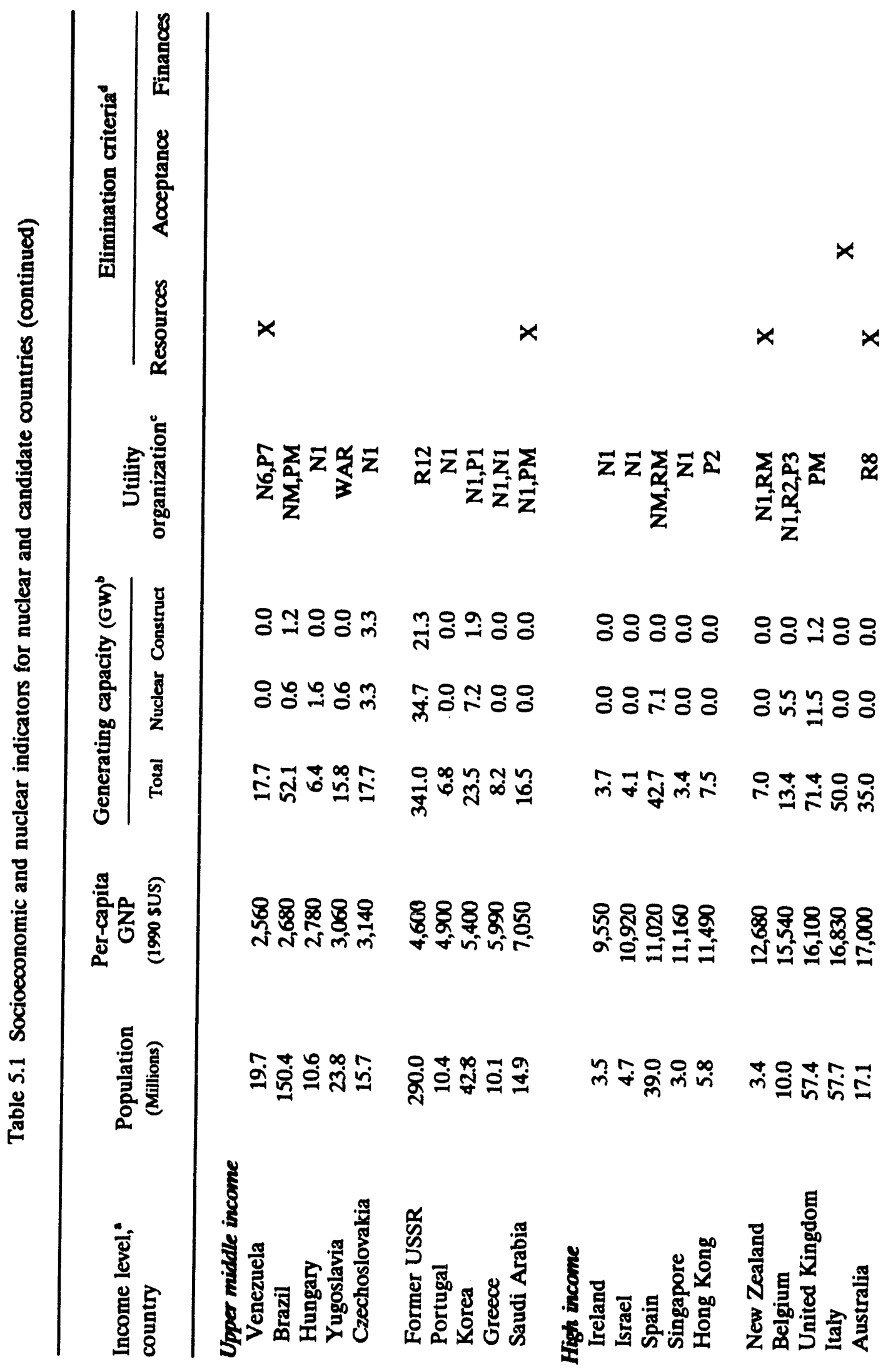



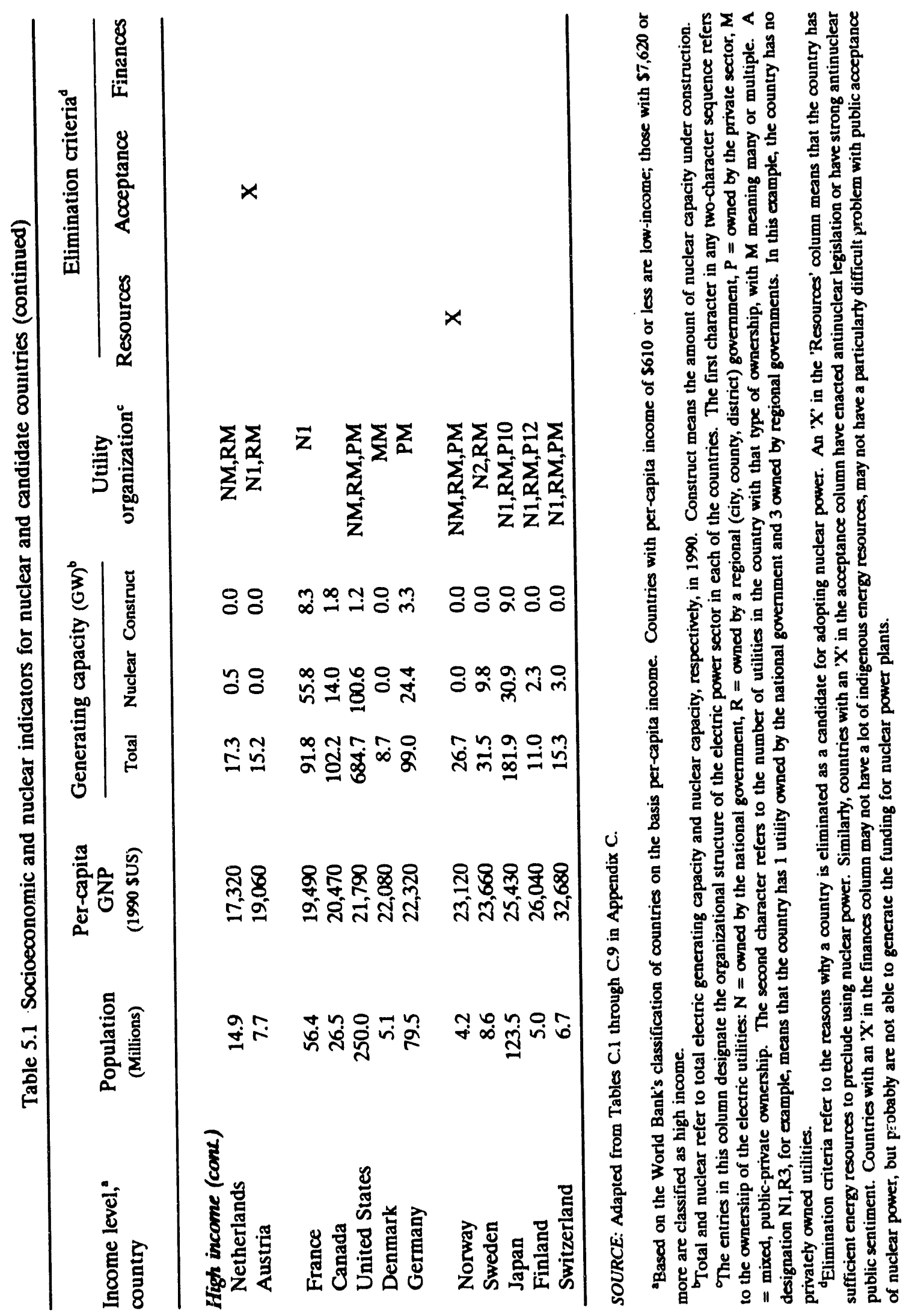
Summary statistics for the 28 nuclear and 25 candidate countries are provided in Table 5.1, condensing much of the information contained in the tables of Appendix C. The table shows the wide range of characteristics of nuclear and candidate countries in terms of population, income, and the industrial structure of their electric power industries. India, Pakistan, Cuba, and China are the only low-income, nuclear countries. With the exception of Italy, all of the G-7 countries operace nuclear power plants. Generally, the low- and middle-income countries have one dominant national utility. With the exception of Poland, all of the European members of the Council for Mutual Economic Assistance (Comecon) have operating nuclear power plants. ${ }^{* *}$ In fact, of the 28 nuclear countries, Bulgaria, a former member of Comecon, is the one with the lowest population. Cuba has the least amount of total generating capacity $(3.2 \mathrm{GW}$ ) for a nuclear country attempting to construct its first nuclear power station [work has been currently suspended on this facility]. On the basis of capacity, the United States is the largest nuclear country with more than $100 \mathrm{GW}$ of nuclear generating capacity. However, the republics of the FSU have the most capacity under construction (more than $21 \mathrm{GW}$ ). Finally, the structure of electric power industries varies widely across countries. The electric power sectors of higher-income countries generally are much more complicated than those of lower-income countries, involving many different types of ownership arrangements.

\subsection{COMPLICATING FACTORS}

Table 5.1 also serves as a bridge between the initial screening for candidate nuclear countries on the basis of income and a more in-depth screening on the basis of three issues. The three issues are shown as elimination criteria in Table 5.1, providing plausible reasons why some nuclear and candidate countries will not construct nuclear power plants over the short to medium term. After comparing the economics of nuclear power with other alternatives, the three elimination criteria are discussed in more detail.

\subsubsection{Economics}

Nuclear power plants have strong competitors to supply new load requirements from both the supply and demand side. On the supply side, as the real price of fossil fuels declined in recent years, the financial attractiveness of nuclear power in comparison with fossil fuel generating alternatives also declined. Also, in some countries, the promise of lower operating costs for nuclear power generation (i.e., compensating for higher, up-front, canital costs) never materialized. For example, a recent study showed that, under the best

"The G-7 countries are the western industrialized countries with the largest economies. The leaders of these countries regularly meet to coordinate economic policies.

** Comecon (founded in 1949) included the former Soviet Union and the East European countries of Czechoslovakia, Hungary, Poland, Romania, Bulgaria, and the former East Germany. Yugoslavia was an associate member. Cuba, Mongolia, and Vietnam were the other full-standard members. Although the historical trading relationships in Comecon were to formally end on February 1, 1991, many ad hoc barter agreements have been negotiated among Comecon members. 
circumstances for all types of plants (i.e., short lead times for constructing nuclear power plants and low-end fuel price assumptions for oil, gas, and coal plants), the total cost of providing electricity using nuclear power would be cheaper than only two $600 \mathrm{MW}$ oil plants (Petroleum Economist 1992). However, the recent movement toward internalizing the costs of environmental externalities will make nuclear plants relatively more attractive.

On the demand side, additional generating capacity requirements have been reduced with the recent push for demand-side management (DSM) measures on the part of electric utuities. Utilities throughout the world are increasingly urged to implement DSM measures, substituting for tradicional supply resources. Estimates of the degree of this substitution are substantial in some countries. In the United States, for example, some estimates show that utilities will obtain as much as a third of their additional resource requirements from the demand side by the year 2000 .

\subsubsection{Indigenous Energy Resources}

As Table 5.1 shows, the, rich energy resource base of many countries eliminates them as nuclear candidates cver the near to medium term Those countries include Nigeria (vast oil and gas reserves), Algeria (vast oil anü gas reserves), Colombia (large oil reserves and large, untapped, hydropower potential), Peru (oil reserves and large, untapped, hydropower potential), Saudi Arabia (vast oil and gas reserves), Venezuela (oil and large, untapped, hydropower potential), Australia (oil, gas, and coal reserves), and New Zealand (large, untapped, hydropower potential).

Some countries can be considered serious candidates for constructing nuclear power over the inedium term because of dwindling energy resources. Perhaps the most important is Indonesia. Presently an oil exporter, Indonesia generates $83.6 \%$ of its electricity from conventional thermal sources (Table C.2) and nearly three quarters of that from oil (Table C.3). However, at its 1991 production level (1.4 million barrels/d), it will exhaust its oil resource base ( 6.6 billion barrels) around the year 2000 (Table C.4). Recognizing this inevitability, the government recently decided to explore construction of Indonesia's first nuclear power plant.

\subsubsection{Public Acceptance}

Political reality in some countries suggests that nuclear power is not a viable option. In Italy, for example, the prospects for nuclear power remain uncertain for political reasons. Construction and operation of nuclear power plants has been suspended by the government through 1992. The country's last two nuclear power stations were permanently shut down in 1990.

There is growing resistance to nuciear power in the historically closed economies of Eastern Europe and the former Soviet Union. The European countries comprising Comecon currently have $13 \%$ of the world's nuclear generating capacity and more than $40 \%$ of the world's nuclear capacity under construction. However, plans to complete the nuclear capacity under construction and to continue to operate existing plants in the region are mejsing increasing resistance. The Ukrainian government, for example, declared the republic 
an ecological disaster zone in the aftermath of Chernobyl. Environmental groups in Eastern Europe have increasingly protested construction of more nuclear power plants. Public reaction in Hungary to the Chernobyl accident was instrumental in the government's decision to cancel $2,000 \mathrm{MW}$ of new nuclear generating capacity. The problem is even more severe in Czechoslovakia, which generates nearly one-third of its electricity from nuclear plants (8 units, 3,264 MW currently) and has eight nuclear units consisting of 5,120 MW capacity under construction. Czechoslovakia is the only country outside the former Soviet Union to build and export Soviet-designed nuclear power stations. The safety of some of those reactors is now under question. More recently, the Austrian government, which has a nuclear-free energy policy, has offered Czechoslovakia $800 \mathrm{MWh}$ of free electricity annually if the Czech government will retire a troubled plant on the border between the two countries, less than $\mathbf{5 0}$ miles from Vienna.

\subsubsection{Financial Cost}

Because of their debt exposure and resulting difficulty in borrowing from abroad, some countries cannot afford the high up-front costs of nuclear power. As shown in Table 5.1, Egypt, the Philippines, and Poland are in that category. Egypt, however, signed a nuclear cooperation agreement with Argentina in 1988 in anticipation of developing a nuclear program, and the Philippines are negotiating with Westinghouse to complete and operate a nuclear power plant that was nearing operation before a variety of circumstances stopped construction.

\subsection{NUCLEAR POWER DECISIONMAKING}

Three levels of decisionmakers must be considered when discussing the construction of commercial nuclear power plants: (1) international, (2) national, and (3) individual utility. The international decisionmaking process is often a barrier to the adoption of nuclear power for certain countries where there are particular concerns about nonproliferation or political stability. There is no set pattern to the relationship between national and utility decisionmaking across the globe. Many variants exist. In many countries, national decisionmaking is equivalent to utility decisionmaking because of the structure of the electric power industry. Decisionmaking in South Korea illustrates this well. Although Korea Electric Power Corporation, the national electric monopoly, is a stock company, it has historically been majority-owned by the South Korean government. Decisions about generating alternatives, therefore, always rest with the government. Decisionmaking in the United States is at the other extreme. Individual utilities make choices about generating alternatives within a regulatory environment established at the national (and state) level.

In addition to levels of decisionmaking, the types of decisions are important-two types dominate. The first relates to an electricity generating strategy. That strategy could be for a nation, a region, or an individual utility. Given the first decision, the vendors for supplying the generating units must be chosen. That choice includes consideration of commercial nuclear power plants.

In the remainder of this section, this decisionmaking process is explored in greater detail. First, how the decisionmaking process affects generating alternatives in nuclear companies 
is examined. Then, the countries that are the most likely candidates to adopt nuclear power over the medium term are evaluated.

\subsubsection{Nuclear Countries}

The United States is an example of a country with very decentralized decisonmaking with respect to the selection of generating alternatives. It has perhaps the most diverse ownership of electric utilities with more than 2,200 utilities either (a) privately owned with shares traded on stock exchanges, (b) publicly owned by the federal government (Tennessee Valley Authority, five federal power marketing agencies), (c) publicly owned by subnational governments (i.e., state, country, or city-owned), or (d) organized as rural electric cooperatives. Broad government policy toward nuclear power-primarily related to licensing and safety-either promotes or inhibits the decision by utilities to adopt it. Once a decision is made to construct a nuclear power plant, the selection of a vendor is a decentralized decision. As is shown in Table 5.1, many of the high income countries have electric power sectors as diverse as that in the United States.

France is an example of a countiy on the opposite end of the spectrum from the United States. EdF, a government monopoly producer, transmitter, and distributor of electricity, has sole authority for nuclear power purchases in the country. Another government-owned corporation, Framatome, is the exclusive supplier of reactors to EdF.

Japan is an example of a country whose decisionmaking on nuclear power falls between the extremes of France and the United States. There is strong central direction with national energy policy long favoring the adoption of nuclear power, but ten privately owned utilities respond not only to the policy directions of the government, but also to the demands of stockholders when deciding on generating alternatives. As in France, however, nuclear power reactor vendors are government-owned and controlled.

\subsubsection{Candidate Countries}

For candidate countries, the rapidly growing economies of the Pacific Rim are the most likely candidates for building nuclear power plants: Malaysia, Thailand, Indonesia, Singapore, and Hong Kong. Many energy-short countries in that region already have substantial commercial nuclear power programs. South Korea, for example, currently generates more than one-half of its electricity with nuclear power (Table C.6) and has 1,900 MW of nuclear capacity under construction (Table C.1). Japan generates more than a quarter of its electricity from nuclear sources and has more than $9,000 \mathrm{MW}$ under construction. Taiwan has decided to proceed with construction of its fourth nuclear power plant.

As noted above, of the candidate countries on the rim, perhaps the most likely to be the first to construct a nuclear power plant is Indonesia. That decision was made by the national government in response to Indonesia's dwindling supplies of oil.

Of the remaining candidate countries on the rim, Thailand has the largest electricity generation (37.4 tWh), but the lowest per-capita income $(\$ 1,420$ per year). Of the remaining Pacific rim countries, Singapore would seem an ideal candidate except for its small 
population, land area, and electricity generation (14.0 tWh). Singapore's economy has seen growing rapidly, mirrored by the growth in energy consumption. Over the last decade, energy consumption has increased at the rate of nearly $6 \%$ annually. More important, energy imports were $15 \%$ of Singapore's exports in 1990-a significant drain on its economy.

Decisionmaking for the adoption of generating alternatives in lower-income countries is generally centralized at the national level. As shown in Tables C.5 and C.9, these countries are typically dominated by one or two utilities-and major decisions are made at the national level. 


\section{CURRENT STRUCTURAL ARRANGEMENTS-WHO IS CONNECTED TO WHOM, WHY, AND IMPLICATIONS FOR THE FUTURE}

This section provides a broader perspective of the nuclear power industry with observations on future directions. Associated with this section, Appendix D lists nuclear power plants, the utilities, and the vendors. It shows the historical relationships between vendor and customer.

\subsection{KEY PLAYERS IN THE WORLD NUCLEAR BUSINESS}

There are four major groupings of vendors, governments, and utilities that have dominated the nuclear power industry in the 1980 s and are the major players in today's market. These groupings are identified by the vendors, but also involve utilities and governments.

\subsubsection{Nuclear Power Incorporated}

NPI is the largest grouping in the nuclear power industry today; it includes: (1) Nuclear Power Incorporated [a joint venture of Framatome (France) and Siemens (Germany)]; (2) Siemens, which controls the reactor vendors Kraftwerk Union (Germany) and is purchasing Skoda Energo (Czechoslovakia); and (3) French reactor vendor Framatome, which controls Babcock and Wilcox (United States). Siemens also controls Siemens Power in the United States, which fabricates nuclear fuel but has not been a vendor, historically. Since 1980 , this group of companies sold $-23 \%$ of the nuclear reactors worldwide and has been responsible for $-23 \%$ of the reactors under construction. NPI as a consortium (Vignon and Shneider 1992) emphasizes nuclear markets in the industrialized countries. NPI has also initiated discussions with industrial organizations in other European countries as potential partners. Siemens and Framatome are partners in some markets and competitors in others.

In the past decade, NPI partners have been the exclusive suppliers for all power reactors in France, Germany, and Czechoslovakia. Both the French utility and Framatome (the reactor vendor) are controlled by the French government. There are not strong direct financial connections between Siemens and the German utilities, but very long-term business relationships do exist. The unification of Germany and the rebuilding of the former East German infrastructure (electrical grid, communications) provide major near-term markets that strengthen Siemens' position. The group clearly has the support of the major national governments with a goal for NPI to create a standard large evolutionary European nuclear power plant that meets all codes and standards across Europe.

Following the recent formation of NPI, there have been major agreements between the German utilities, the French utility, and NPI. The EVU (association of German nuclear utilities) Planungsauftrag program and the EdF (national utility) REP-2000/N4+ programs are being combined with input from NPI to produce a single set of specifications and requirements for new reactors. Conceptual design is nearing completion of the proposed NPI European EPR. Parallel efforts are under way between French and German regulators to "achieve some harmonization of their requirements" (Joint 1992). This combining of 
efforts is a complex task given the historically different structures of the German and French industries. In France, the French utility is responsible for overall design and integration of the plant with the vendor, Framatome, providing the reactor system. In Germany, the vendor Siemens is responsible for the entire plant. For NPI, the nuclear island design responsibility is a joint effort of Siemens and Framatome, while the balance of plant/overall $\mathrm{AE}$ is a joint responsibility of Siemens and the French utility, EdF.

\subsubsection{Asea Brown Boveri}

The Swedish-Swiss company, Asea Brown Boveri, owns multiple reactor vendors including ABB Combustion Engineering in the United States and ABB-Atom in Sweden. It is a major reactor supplier in Scandinavia, the United States, and South Korea, but does not have exclusive domestic markets. Recent multiple sales to South Korea have expanded its market share. It has the broadest range of nuclear power plant products of any vendor.

$\mathrm{ABB}$ is the largest industrial equipment manufacturer (steam turbines, electrical equipment, etc.) in the world. It has also grown very rapidly in the last decade. While it is not first in nuclear reactor power sales, its sales of other equipment to utilities provide it with unique broad access to utilities worldwide.

\subsubsection{Hitachi, General Electric, and Toshiba}

Hitachi, General Electric, and Toshiba (HGET) have joint agreements for development of BWRs. Since 1980 , this group has sold $\sim 11 \%$ of the world's reactors and has been responsible for $\sim 11 \%$ of the nuclear power construction. Most of these sales have been in Japan, where Japanese utilities traditionally buy from one or two favored reactor vendors. The major development program of this group in the 1980s has been the advanced boilingwater reactor (ABWR), where the largest utility in Japan-Tokyo Electric Company (TEPCO)-is a major partner with HGET. The first two ABWRs are currently under construction at a TEPCO site. This close utility-vendor relationship is one of the identifying characteristics of the Japanese utility-vendor structure.

\subsubsection{Atomic Energy of Canada Limited}

Atomic Energy of Canada (AECL) is a government-owned vendor that has successfully continued to fill a niche market for nuclear power reactors. The CANDU reactor uses natural uranium, which greatly simplifies the nuclear fuel cycle and allows small countries to produce their own nuclear fuel. AECL has recently sold another reactor to South Korea and has a continued partnership on fuel development with South Korea (Doust 1992; KEPCO 1992). Thus, the ties between AECL and South Korea are strengthening.

The South Koreans and AECL are considering recycle of spent LWR fuel into CANDU reactors (Pillay 1992). If successful, this recycling effort would allow the waste from one reactor type to become the fuel for a second reactor type with significant savings in fuel costs. There are many uncertainties, but if this effort is successful, it would create a second niche market for heavy-water power reactors for South Korea and AECL. 


\section{2 EMERGNG NUCLEAR GROUPS}

There are a number of countries and other organizations that are building large commercial nuclear power supplier organizations with capabilities to become international nuclear reactor vendors. This is a slow process requiring a decade or more.

\subsubsection{Mitsubishi}

Historically, Mitsubishi supplied PWRs under a Westinghouse license exclusively to Japanese utilities. It is the vendor for $9 \%$ of the power reactors under construction worldwide since 1980. In Japan, each utility buys from one or two vendors with very close utility-vendor relationships. The earlier license agreements with Westinghouse have expired. In the last year, Mitsubishi has entered the international nuclear power business with bids on components and plants worldwide. It has also won major contracts for replacement equipment (NEIb 1992). The Mitsubishi family of companies includes -190 members with annual sales of $\$ 300 \times 10^{9}$, which makes the group one of the largest in the world with extraordinary financial and technical capabilities. Thus, a new, large nuclear reactor vendor has entered the world market.

On March 24, 1992, Mitsubishi signed a 10-year-cross-licensing and joint-development agreement covering nuclear power technology with Westinghouse where both partners are equal partners. Given the different and complimentary strengths of the two companies, this partnership has the potential of being an important venture. The "lead" vendor for sales to third countries may be based on customer preferences.

\subsection{South Korea}

South Korea does not have a reactor vendor, but the government is encouraging the rapid development of vendor capabilities (Kim 1992, Taylor 1992 ${ }^{b}$ ) through the governmentcontrolled national utility. With rapid economic growth, nine additional power plants are to be built by 2001 with an additional nine units by 2006, making the Korean program one of the largest nuclear power programs in the world. Each subsequent power reactor purchased by the South Korean utility-Korean Electric Power Company (KEPCO)-has had associated with it a greater technology transfer and increasing domestic manufacturing content for South Korean suppliers. This indicates that within a decade, South Korea will fully manufacture its own nuclear power reactors. The utility estimates that for PWRs, Korea supplies $88.2 \%$ of the technology in the current plants and will supply $95 \%$ by 1995 . It is planned to build Korean Standard Nuclear (KSN) 1000 Mw(e) PWRs based on the ABBCombustion Engineering System 80 design. South Korea has constructed PWRs and CANDU reactors with a long-term goal of three PWRs to each PHWR.

As in France, many of the nuclear companies are controlled or partly owned by the utility. Korea Heavy Industries and Construction Company, Ltd., (KHIC) supplies the nuclear system. Korea Power Engineering Company, Inc., (KOPEC) is responsible for overall power plant design and engineering. It is $98 \%$ owned by KEPCO. Another KEPCO company-Korea Electric Power Operating Services Company, Ltd., (Kepos) does nuclear 
power plant maintenance, overhaul, and refuelling. Last, Korea Nuclear Fuel Company, Ltd., (KNFC), 95\% owned by the utility, provides fuel fabrication services for their PWRs.

\subsubsection{People's Republic of China}

China has a centrally planned economy with the utility and vendor owned and controlled by the government. China recently completed its first Chinese-designed nuclear power plant, has several larger nuclear power stations under construction, and announced a recent sale of a power reactor to Pakistan (NEIa 1992; NNd 1992). This is in addition to the purchase of two power reactors from Framatome that are now under construction. The internally manufactured power plants contain a significant number of components from western suppliers with Framatome (France) the largest supplier. The potential domestic market for nuclear power plants is very large; thus, there is the potential for China to internally develop a large nuclear power industry that could also export nuclear power reactors.

\subsection{OTHER NUCLEAR INDUSTRIAL GROUPS}

\subsubsection{Westinghouse}

Historically, the largest vendor in the world was Westinghouse, which dominated the market before 1980 . Since $1980,2.3 \%$ of the power reactors under construction have been Westinghouse reactors. Several former licensees are now competitors, and Mitsubishi is now an equal partner. The large number of Westinghouse reactors built before 1980 provides the company with a significant customer base, but the financial difficulties of recent years (Schroeder 1992; Baker 1992) and its relatively small size are significant constraints. The traditional market for Westinghouse has been the United States, and the lack of orders in the United States has limited sales. Furthermore, Westinghouse does not have an assured domestic market. Currently, Westinghouse is providing much of the technology for the Sizewell nuclear power station which is under construction in Great Britain. There are serious discussions for additional power plants (NNc 1992) of this type.

Recently, Westinghouse signed a 10-year agreement with Mitsubishi Heavy Industries, Ltd., to cooperate on development of nuclear technologies and offer them to markets in "third countries" (NNa 1992; Westinghouse 1992). It also has agreements with Britain's Nuclear Electric and has announced plans for a joint bid to Taiwan Power Company for their next two nuclear power reactors (Airozo 1992).

\subsubsection{Russia}

The recent independence of Eastern European countries and the breakup of the FSU are rapidly altering the structure of the utilities and the Russian nuclear power industry. To understand these changes, some history must be understood.

- Eastern Europe and the FSU were centrally planned economics with the additional characteristic that much of the electric sector of Eastern Europe and the FSU was operated as a single unit across national boundaries. For example, in Bulgaria, $40 \%$ of the electric power is from a single station. No national utility would put such a 
large fraction of its total capacity at a single site because of the reliability concerns in the event of an accident at a single site.

- The FSU had effectively two and a half reactor vendors with the technical infrastructure located in Russia and Czechoslovakia.

- One Russian "vendor" manufactured the RBMK-the Soviet graphite, watercooled reactor type at Chernobyl.

- A second Russian "vendor" produced the VVER, the Soviet version of the PWR used in most western countries.

- The third "vendor," with most but not all capabilities, was Skoda Works of Czechoslovakia. It manufactured later versions of the $440 \mathrm{MW}(\mathrm{t}) \mathrm{VVER}$ and was beginning to manufacture large VVER reactor components.

- With the exception of sale of power reactors to Finland, the FSU was not an international reactor vendor (i.e., no sales to foreign countries outside the communist block).

Two events continue to change the characteristics of the nuclear industry of the FSU-Chernobyl and the breakup of the FSU. While the ultimate structure of the industry is uncertain, several observations can be made.

- A major world-class industrial accident (Bhopal, Three Mile Island, Comet Aircraft) usually results in a product being discontinued and the organization responsible being radically downsized or eliminated. Chernobyl effectively eliminated the RBMK as a future reactor type and the "vendor."

- Significant new nuclear power plant construction in the FSU and most of Eastern Europe (except for completion of nuclear power plants that are almost complete) is likely to be limited for four different reasons:

1. political impact of the Chernobyl accident;

2. economic difficulties that limit capital for new power plants and that ultimately reduce power demand;

3. inefficient use of energy, which will limit electrical demand growth as more energy efficient technologies are adopted; and

4. the structure of the electrical grid. (With the breakup of the FSU and Eastern Europe, individual countries will develop independent national utilities. From a national planning basis, multiple power stations are desired for reliability. The size of the national grids will limit the demand for large power stations of any type which, in turn, limits demand for new nuclear power stations.) 
- The market for nuclear power plant services by the Russian VVER reactor vendor will become highly competitive in the nations of the FSU and Eastern Europe outside Russia. This competition will reduce Russian vendor activity. The major strength of the vendor will be the low-cost but knowledgeable work force.

One special characteristic of the nuclear industry of Eastern Europe and the FSU is the likely future presence of the German reactor vendor Siemens and, through NPI, the French vendor Framatome. Two separate activities are responsible for this increased presence.

1. There has been one internationally recognized success of the Russian nuclear power industry: the Finnish power plant at Louisia. This is a unique station that houses two Russian reactors with Siemens control systems and other western safety features. In many years this station has been the most reliable nuclear power station in the world. Among other things, it is a powerful advertisement for Siemens ability to upgrade VVER reactors.

2. Siemens is purchasing controlling interest in Skoda Energo (Kralovec 1992) of Czechoslovakia, which built many of the VVER reactors in Eastern Europe and has the greatest understanding of these power reactors outside Russia.

The above factors provide Siemens with a very strong position to upgrade VVER reactors in Eastern Europe and the FSU.

It will be some time before definitive conclusions on the directions of the Russian nuclear program can be made and an understanding of what capabilities will survive is attained. It is noteworthy that the Russian vendor is the only significant vendor in the world that does not have long-term agreements with other reactor vendors to reduce costs and spread risks.

\subsubsection{India}

The Indian nuclear power program is controlled by the government (Wood 1991) and has slowly expanded in the last decade. Continuing financial troubles have and continue to restrict the program. While a substantial number of power reactors have been built, it is noted that these reactors are relatively small compared to those built elsewhere (Appendix D); thus, the industrial infrastructure requirements are substantially less. No significant efforts have been made to export nuclear power products.

\subsubsection{New Vendors}

Several countries have industrial organizations which, at one time, appeared to be likely future reactor vendors, but where the transition did not occur. In each case, specific local conditions prevented the emergence of a full-scale nuclear power reactor vendor. In each case, a shift in specific policies could result in an emerging reactor vendor.

- Italy. The Chernobyl accident resulted in a 5-year moratorium on nuclear power in Italy. Vendor capabilities were being developed by Ansaldo. 
- Spain. Reduced growth in electric demand, the Chernobyl accident, and concerns about separatists movements have stopped creation of a Spanish reactor vendor.

- United States. In the United States, one vendor, General Atomics, has been developing a different type of advanced reactor, the modular high-temperature gascooled reactor. The reactor has potential safety advantages. Several prototypes have been built. While this technology is still under development, it has not been commercialized. Whether General Atomics becomes a vendor depends upon the success of this specific product.

\subsection{COUNTRIES WITH SIGNIFICANT NUCLEAR POWER PROGRAMS BUT LIMITED DOMESTIC SUPPLY INDUSTRY}

There are a number of countries with multiple nuclear power plants that have chosen not to create a local supply industry. This generalization includes countries such as Finland, Taiwan, and Belgium. 


\section{REFERENCES}

Airozo, D. 1992. "Westinghouse, NNC Formally Announce Plan for Joint Bid to Tia Power," Nucl. Week 33(44), 2.

Arthur, W. B. 1990. "Positive Feedbacks in the Economy," Sci. Am. 262(2), 92.

Baker, S., Schroeder, M., and Dobrzynski 1992. "Westinghouse: More Pain Ahead," Bus. Week 3296, 32.

Catalano, L. M. I., ed. 1988. International Directory of Electric Utilities, McGraw-Hill, Inc., New York.

Doust, R. 1992. "Canadian-Korean Partnership Works Toward a Tandem Fuel Cycle," Nucl. Eng. Int. 37(453), 36.

Energy Information Administration January 1992. International Energy Annual 1990, DOE/EIA-0219(90), Washington, D.C.

Hill, L. J. 1988. Public Power in the U.S. Electric Utility Industry: Regulatory Issues and Comparative Financial Indicators Across Ownership Types, ORNL/TM-10497, Martin Marietta Energy Systems, Inc., Oak Ridge National Laboratory, Oak Ridge, Tennessee.

Hill, L. J. 1992. "Pricing Initiatives and Development of the Korean Power Sector: Policy Lessons for Developing Countries," Energy Policy 20(4), 344-354.

International Energy Agency 1990. World Energy Statistics and Balances, 1985-1988, Paris.

Kaijser, A. 1992. "Redirecting Power: Swedish Nuclear Power Politics in Historical Perspective," Annu. Rev. Energy Environ. 17.

KEPCO 1992. "KEPCO Invites AECL CANDU Bid to Supply More Wolsung Units," Nucl. Week, p. 3.

Kim, B. 1992. "Korea: Going for More Home-Grown Plants," Nucl. Eng. Int. 37(453), 30.

Knox, R. 1992. "Analysis of Load Factors by Vendors," Nucl. Eng. Int. 37(455), 23.

Kralovec, J. 1992. "Skoda Sets Out Its Stall in the World Market," Nucl. Eng. Int. 37(454), 45.

NEIa 1992. "China Starts Up the First of a Nuclear Dynasty," Nucl. Eng. Int. 37:(453), 39.

NEIb 1992. "Steam Generator Contracts Reflect Industry's New Trends," Nucl. Eng. Int. 37(455), 2. 
NNa 1992. "W/Mitsubishi Sign Pact: Other Collaborations," Nucl. News, 65.

NNb 1992. "Joint France-German Design Partly Unveiled, Nucl. News 35(10), 52.

NNc 1992. "NE Prepares Its Case for More Large PWRs, Nucl. News 35(10), 53.

NNd 1992. "Deal Closed with China for 300-MWe PWR Impact," Nucl. News 35(2), 40.

Pillay, K. K. S., Menlove, H. O., and Picard, R. R. 1992. Safeguardability of Direct Use of Spent PWR Fuels in CANDU Reactors, LA-12432-MS.

Schroeder 1992. "Does Everything Add Up at Westinghouse Credit?," Bus. Week.

Taylor, G. M. 1992a. "Qinshan: China's First Nuclear Power Plant," Nucl. News 35(10), 39.

Taylor, G. M. 1992b. "KEPCO Plans 18 More Reactors by 2006," Nucl. News 35(14), 41.

Thurow, L. 1992. Head to Head: The Coming Economic Battle Among Japan, Europe, and America, W. Morrow and Company, Inc., New York.

United Nations 1991. Energy Statistics Yearbook, 1989, New York.

Vignon, D., and Schneider, D. 1992. "NPI's New Reactor Takes Further Step Along the Evolutionary Road," Nucl. Eng. Int. 37(453), 48.

Wallace, R. 1992. "DRAM Dream Team," Electronic Engineering Times.

Westinghouse Public Relations 1992. "Westinghouse, MHI Sign New Nuclear Power Cooperation Agreement," K60-124.

Wood, J. 1991. "Can Nuclear Pay Its Way in India?" Nucl. Eng. Int. 36(449), 52.

World Resources Institute 1990. World Resources, 1990-1991, Oxford University Press, New York. 
Appendix A. DATA SHEETS ON THE VENDORS, SUPPLIERS, AND SIGNIFICANT ORGANIZATIONS IN THE NUCLEAR POWER INDUSTRY 


\section{Appendix A. DATA SHEETS ON THE VENDORS, SUPPLIERS, AND SIGNIFICANT ORGANIZATIONS IN THE NUCLEAR POWER INDUSTRY}

This appendix is a collection of information about reactor vendors. These data are interpretations of articles from the technical press plus data from financial and business summary documents. The composite of this information is thought to provide a representative picture of the reacter vendors. The sources of the individual statements are usually provided; however, the accuracy of each stateme $\mathrm{tt}$ has not been verified.

The data are provided in two forms:

1. a summary table that identifies the reactor vendors and their parent organizations [i.e., a corporation, a group of companies (keiretsu), or governmont agencies] plus other relevant information and

2. reactor vendor data sheets (a page, or ir some cases two or three pages, of selected background information on particular vendors). 


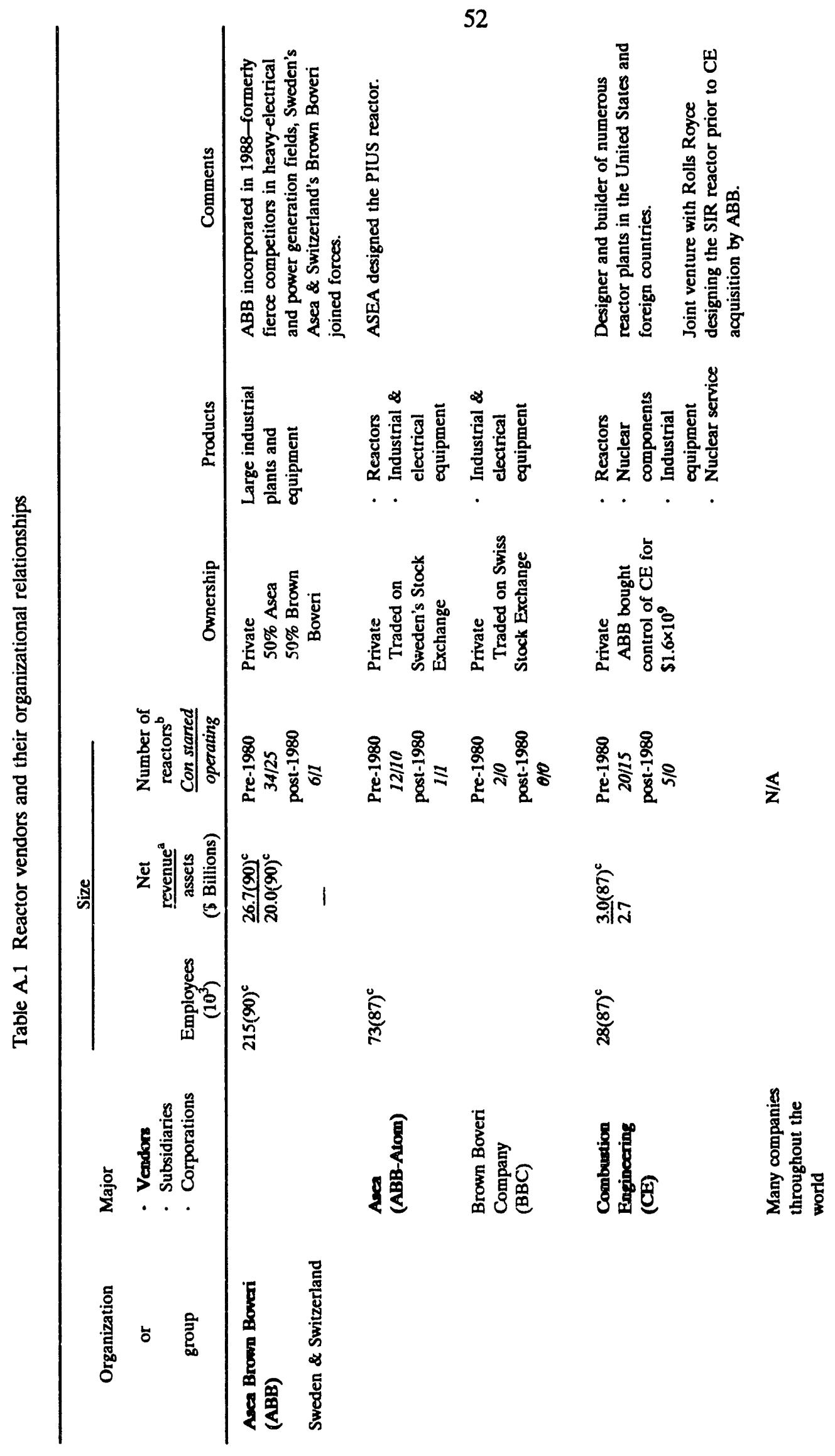




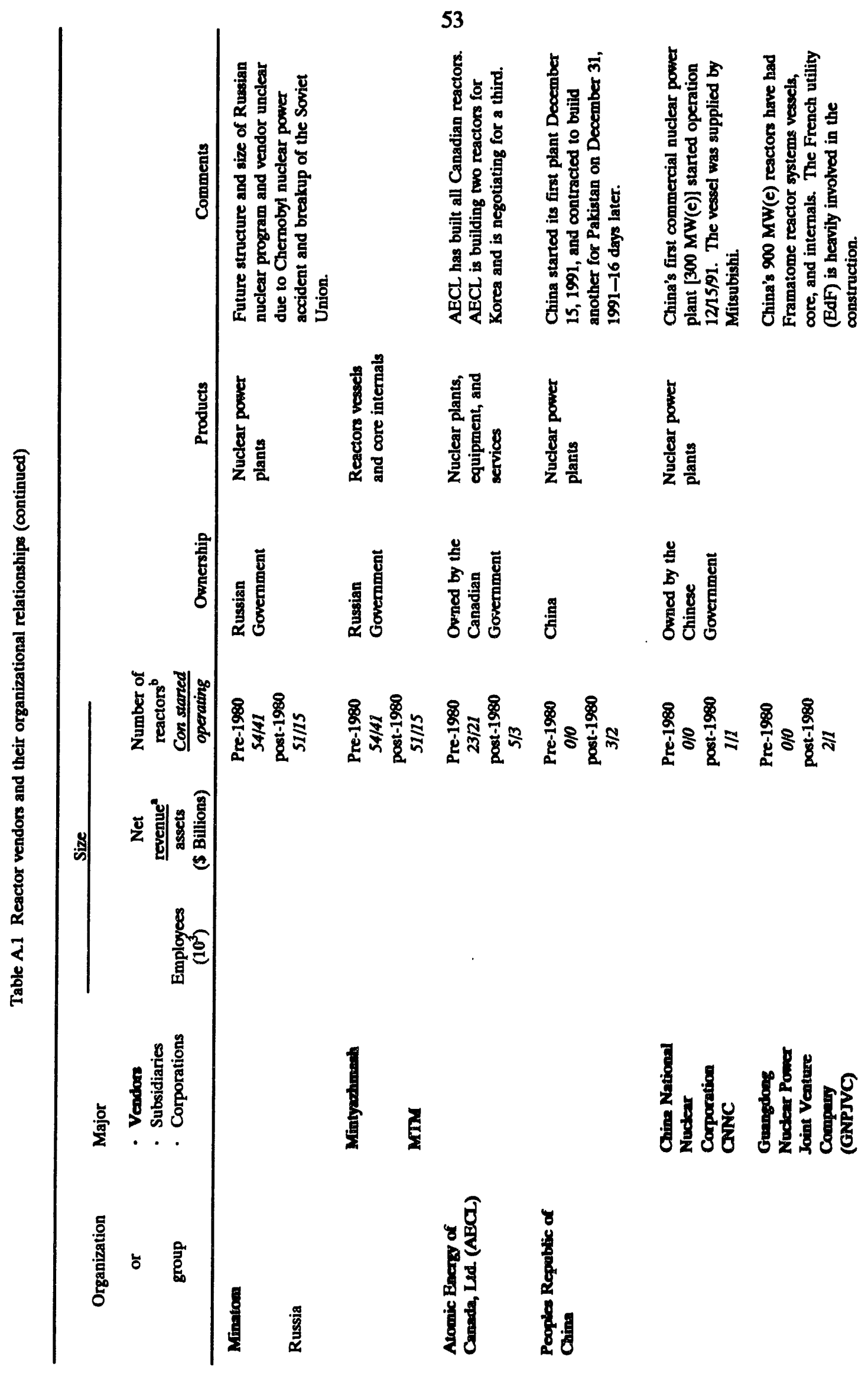




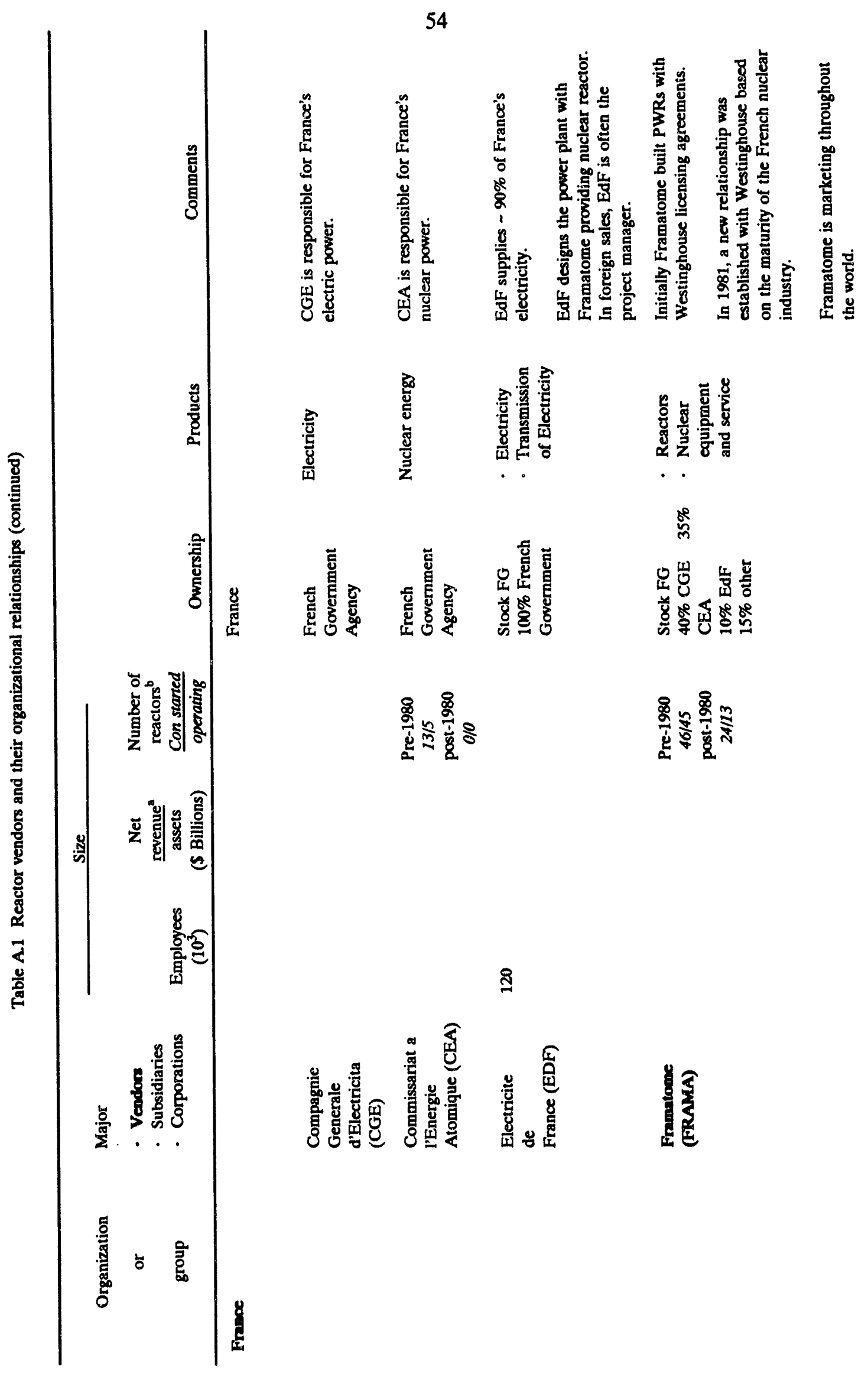




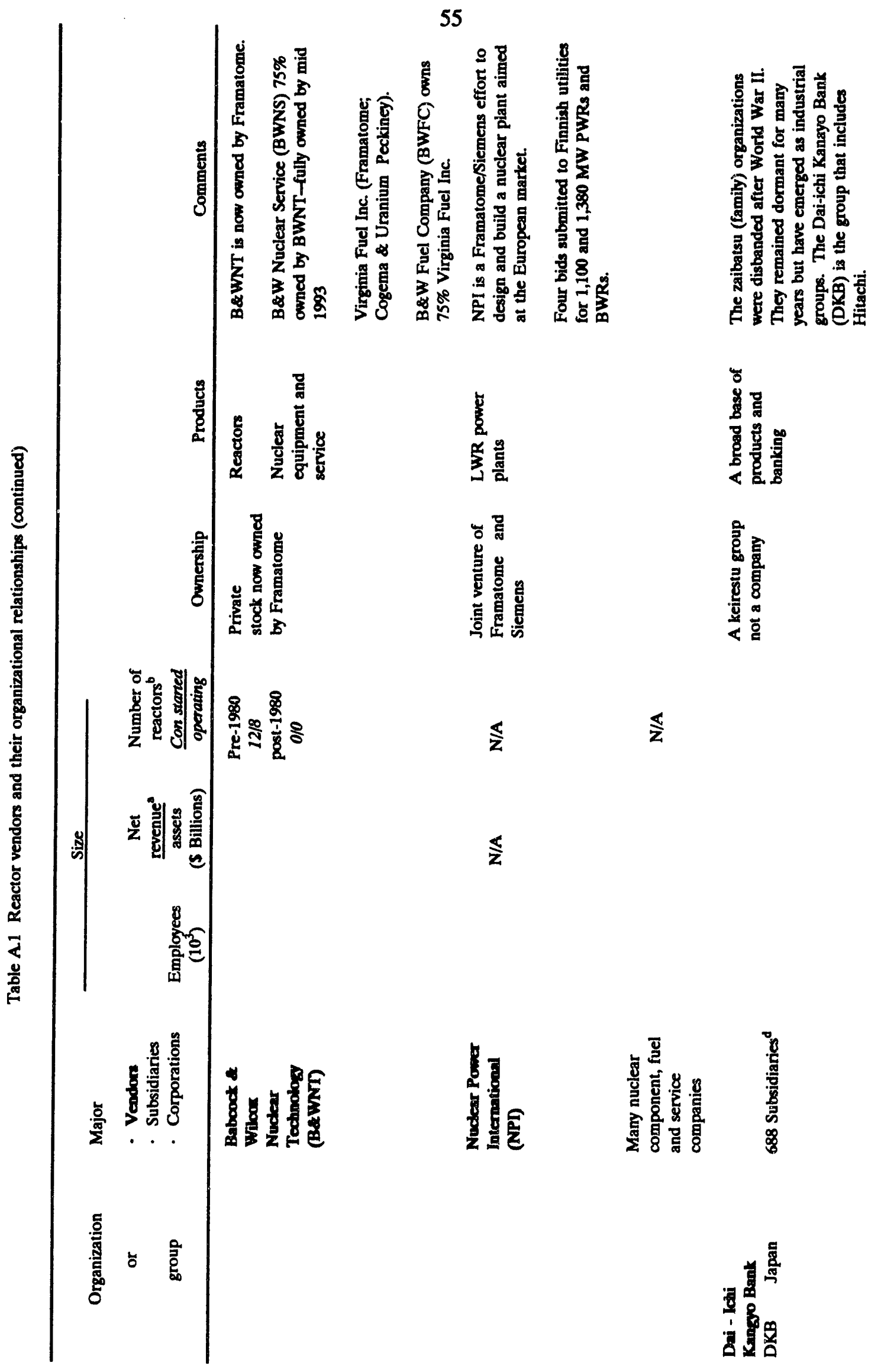




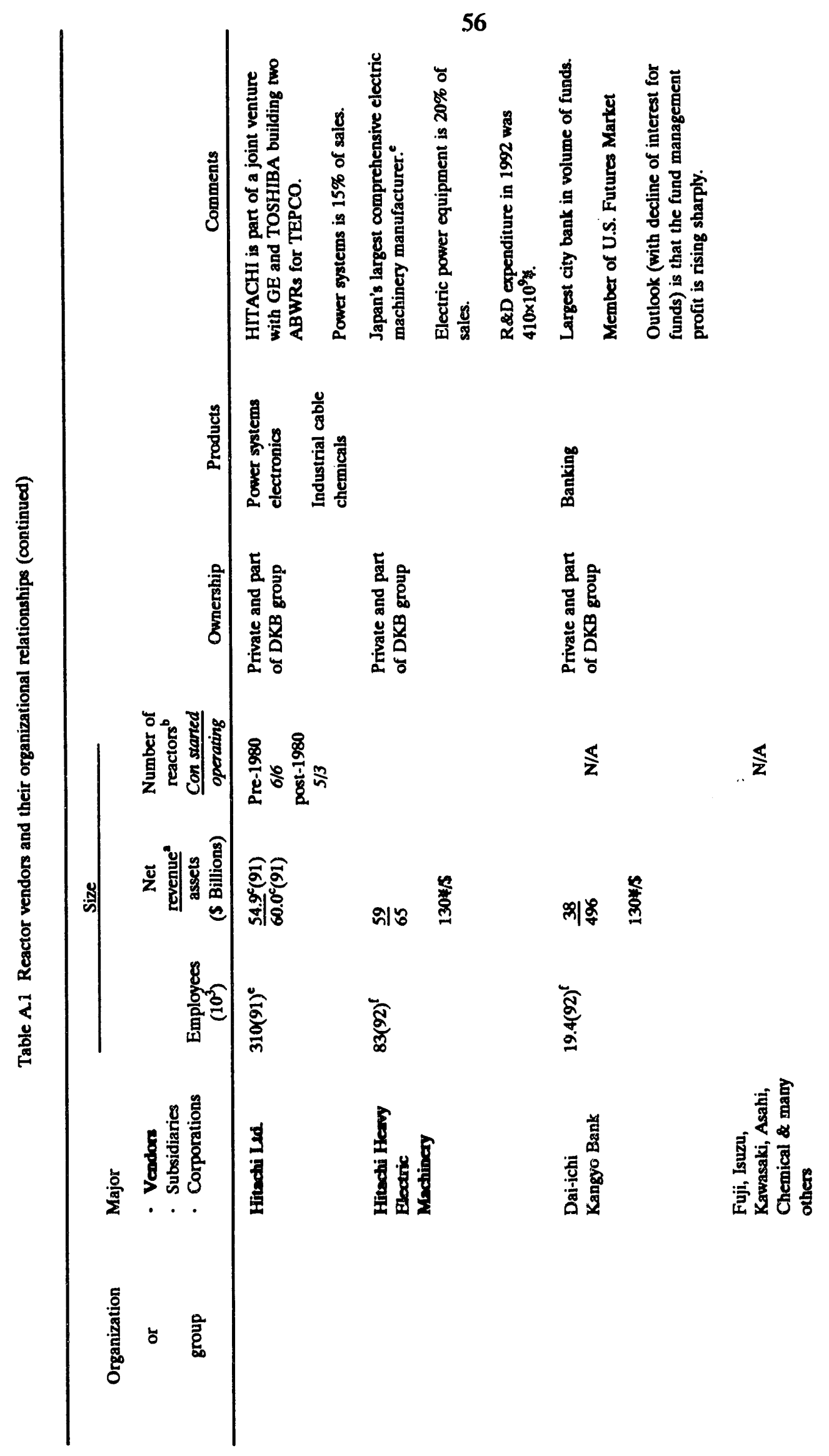




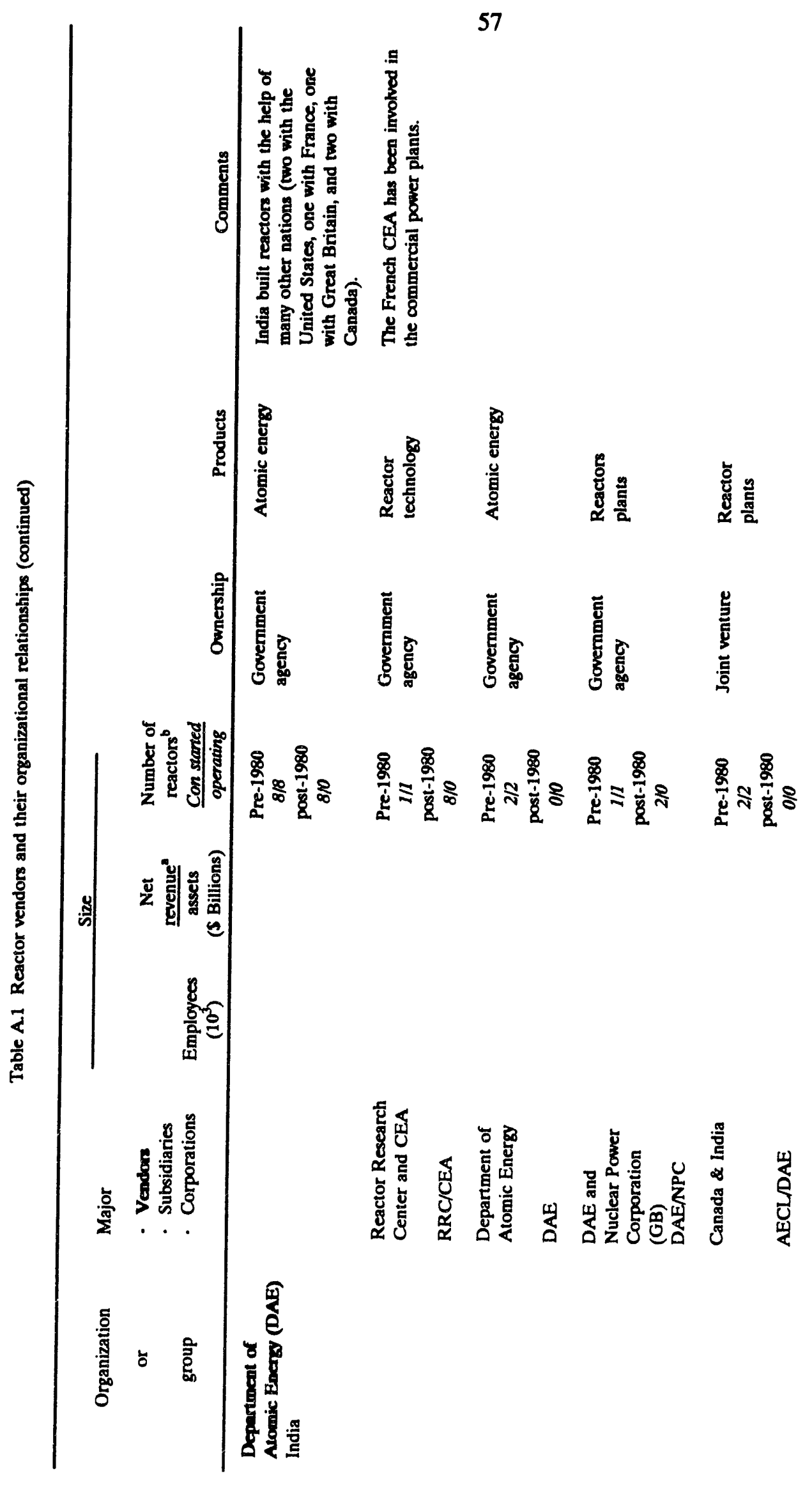




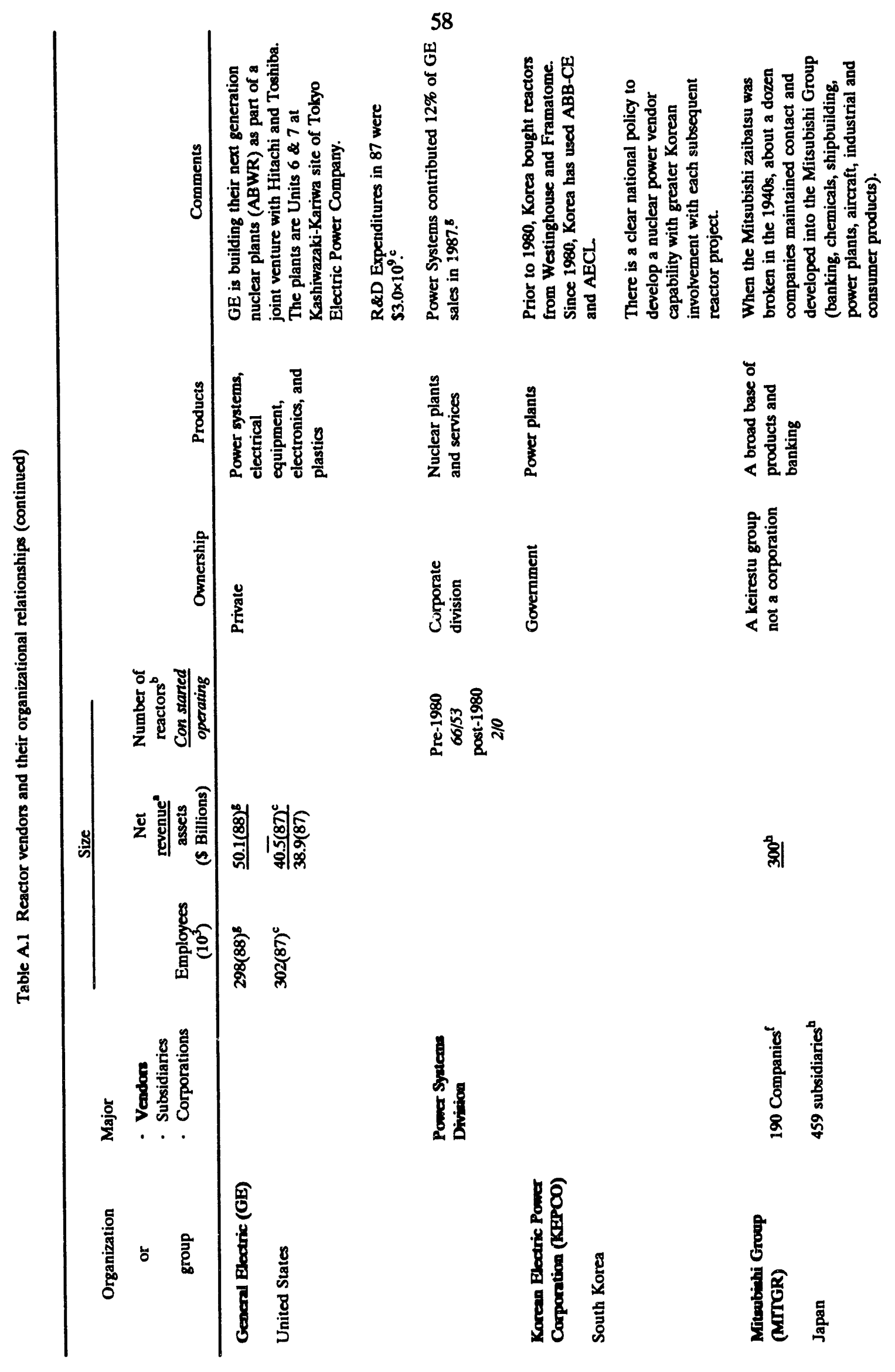




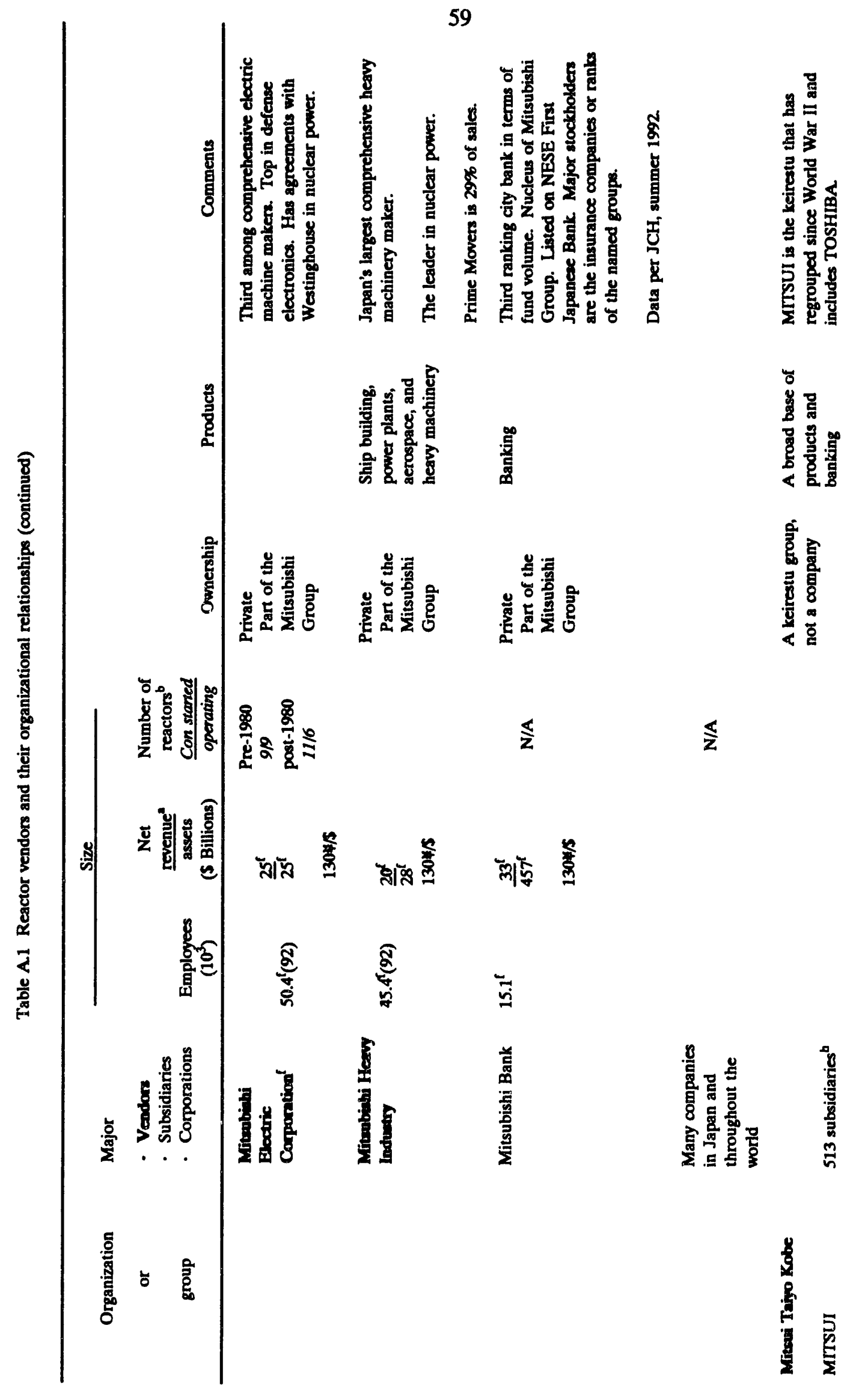




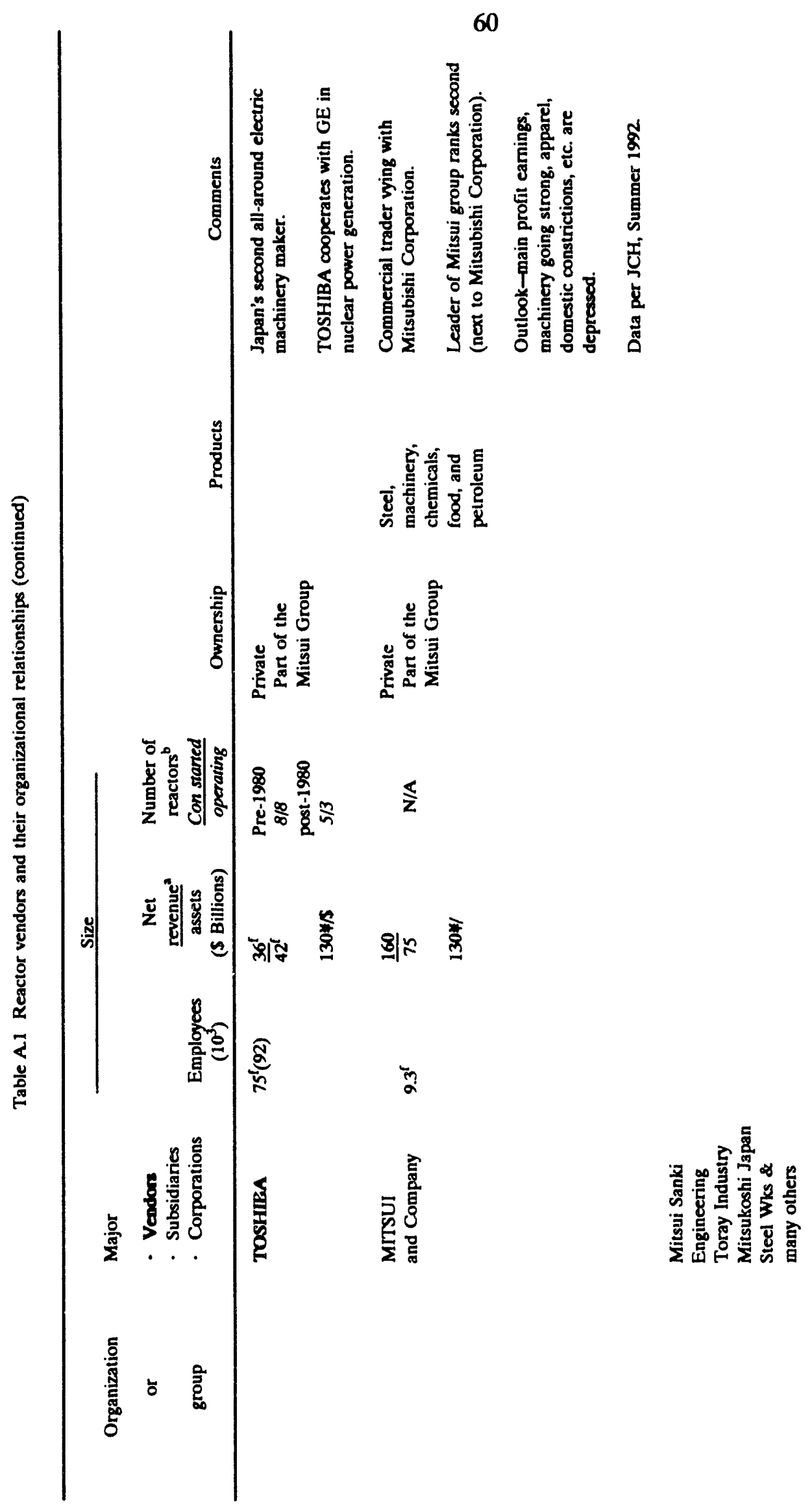




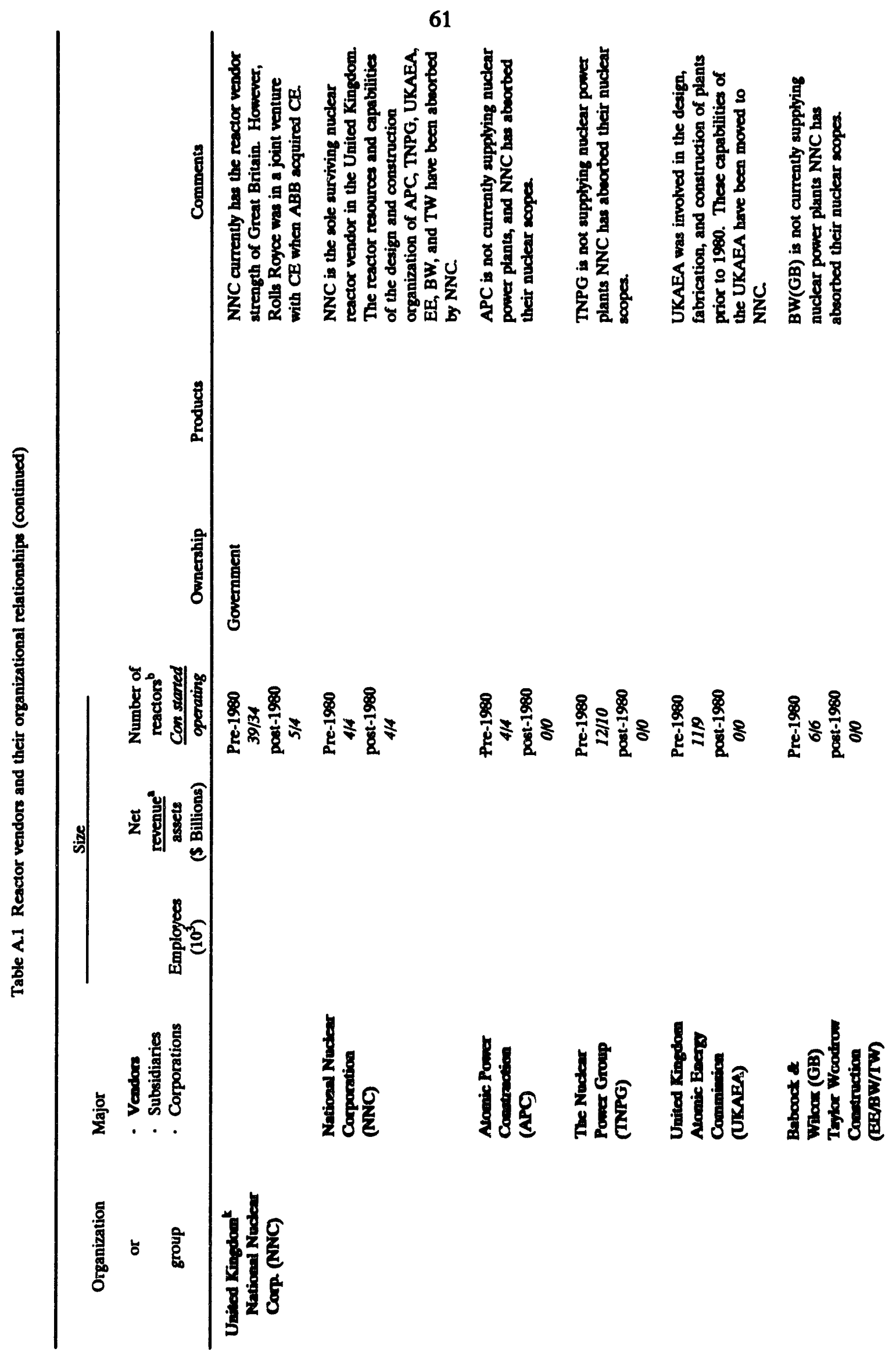




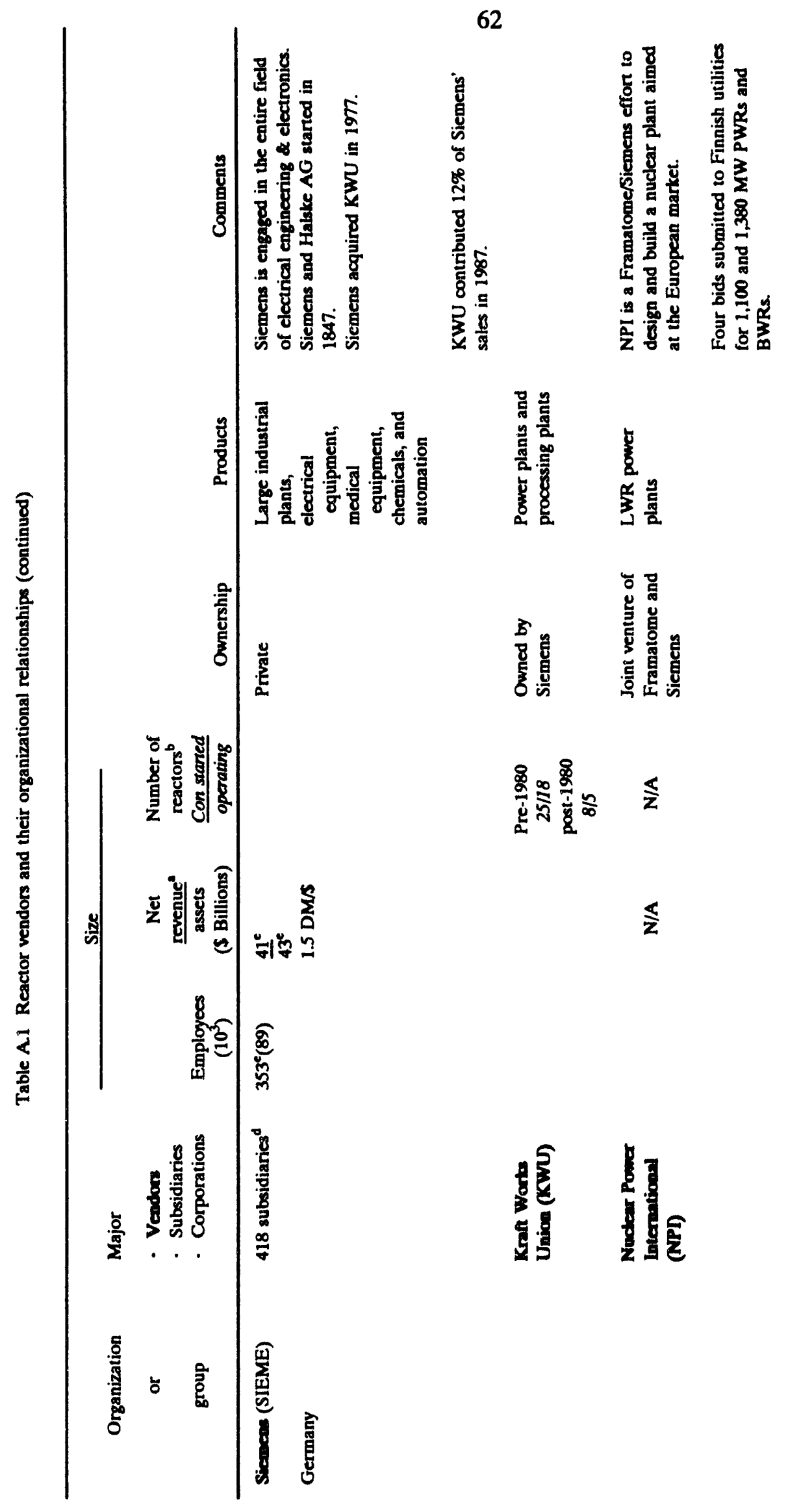




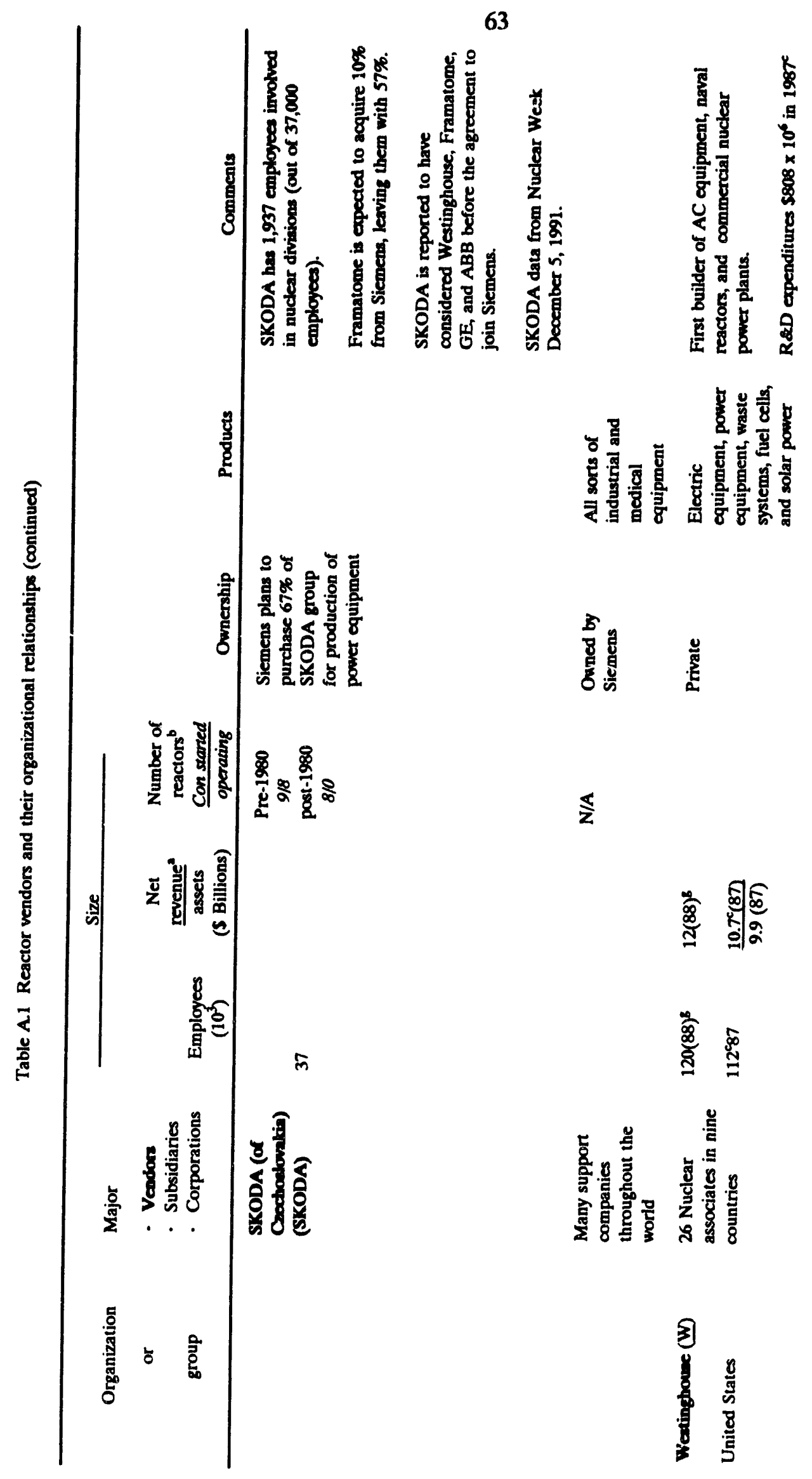




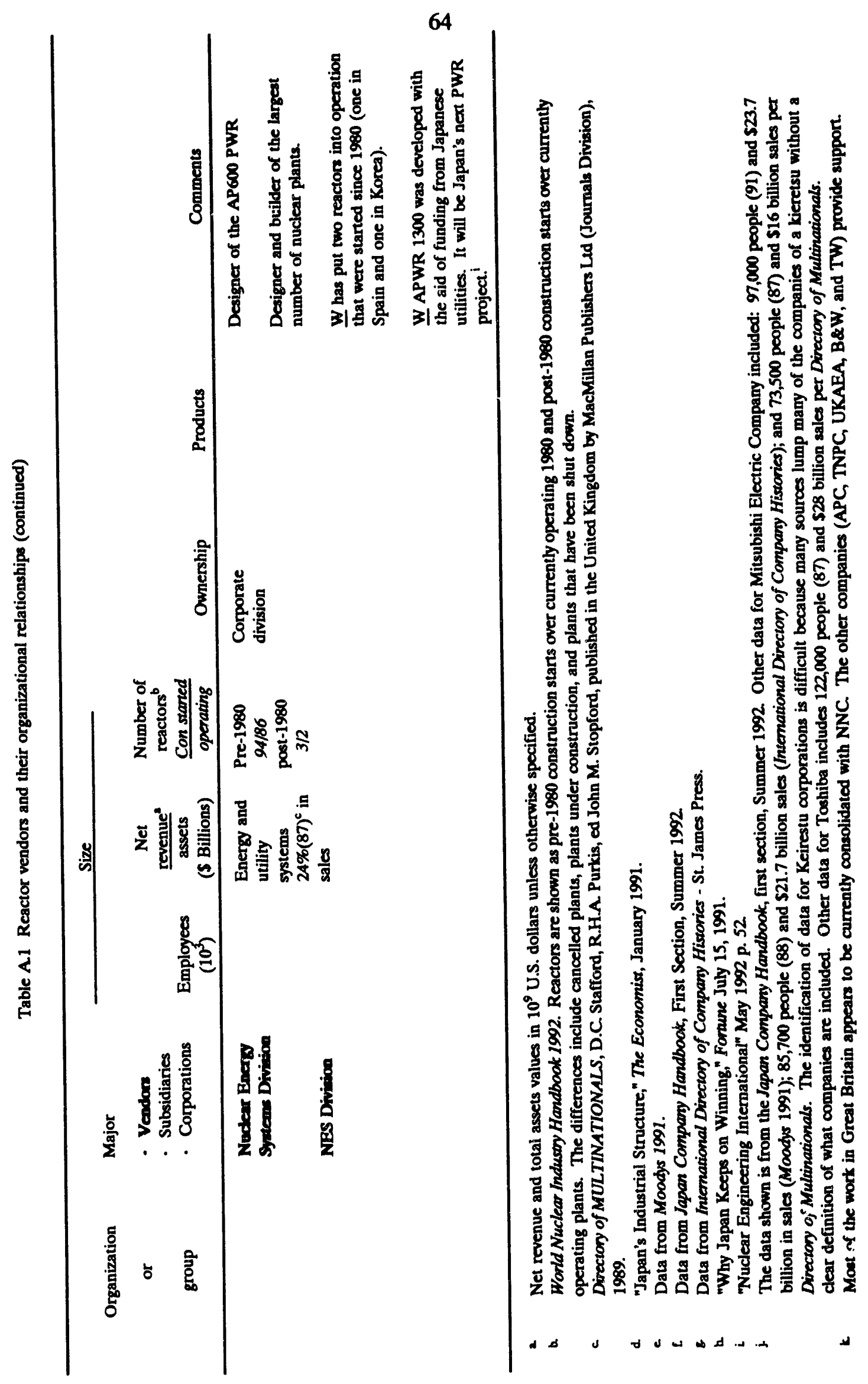




\section{VENDOR DATA SHEET}

ORGANIZATION:

ABB

Name

ABB ASEA Elrown Boveri LTD

Address

P. O. Box 8131

CH-8050 Zurich, Switzerland

Phone \#

(41-1) 3177111

Fax \#

(41-1) 3114897

\section{TYPE/PURPOSE:}

SIZE: 215,154 Employees/Total currẹnt assets $\$ 19,961 \times 10^{6}-1990$ Balance Sheet ${ }^{2}$

\section{HISTORY/LINKAGES:}

- $\quad$ Established in Switzerland on January 5, 1988, by ASEA ABB 50\% (Sweden) and Brown Boveri Ltd. (BBC) $50 \%$ (Switzerland) as a jointly held holding company for approximately 800 electrotechnical subsidiaries.

- $\quad$ ABB acquired Combustion Engineering in 1990.

\section{COMMENTS:}

- ABB Atom submitted bids for BWR for BWR-90 designs $1170 \mathrm{MW}$ and $1350 \mathrm{MW}$ (the cost of ABB Atom's plant was estimated at \$2 billion) for proposed Finnish plant.

- $\quad A B B$ Atom has won an order to supply some of the reload fuel for French $1300 \mathrm{MW}(\mathrm{e})$ PWR reactors. The order covers the delivery of four lead assemblies in 1992 and four demonstration assemblies in 1993, which should lead to the supply of two complete reloads. EdF has a policy of developing alternate suppliers, but this is the first time they placed an order for $1300 \mathrm{MW}(\mathrm{e})$ fuel outside of France.

- $\quad \mathrm{ABB} C-\mathrm{E}$ is gearing up to compete in BWR outage services with GE. When ABB bought $C E$ for $\$ 1.6 \times 10^{9}$, it was in primary competition with Westinghouse and $B \& W / F r a m a t o m e$ in nuclear service and PWR fuel.

- $\quad A B B$ is also a $B W R$ vendor, and $C E$ provides the mechanism for them to compete in the U.S. BWR market share, GE has been the sole U.S. supplier. Swedish plants have consistently shorter refueling outages, and $\mathrm{ABB}$ is "wooing" utility executives with trips to Sweden to view outagge operations. They claim to be going for half the $\$ 1 \times 10^{9}$ anıual ronfuel BWR service market in the United States.

- Moody's 1991

- $N W 10 / 31 / 91$

- $N N$ 12/91/page 68 
$\Delta \quad$ ABB-CE Yonggwang Unit \#3 (Korea Electric Power Company) will start up in 1995, which is proof that nuclear power stations can be built in 5 years. Yonggwang Unit \#4 will follow a year later. Last year, ABB-CE received an order for two additional units to be built at Ulchin (Ulchin $3 \& 4$ ) also on 5 -year schedules. Short schedules result in very economic nuclear power plants.

A ABB-CE is expected to bid on building two 1000-MW reactors for Taiwan (Taipower 7 \& 8). GE, Westinghouse, and Framatome are also expected to bid. 


\section{VENDOR DATA SHEET}

\section{ORGANIZATION:}

Name

Address

Phone \#

Atomic Energy of Canada, Ltd.

AECL

Fax \#

TYPE/PURPOSE:

- Government-owned company.

- Design, build, and operate reactors in Canada.

SIZE:

HISTORY/LINKAGES:

COMMENTS:

- Korean Electric Power Corporation (KEPCO) has invited AECL CANDU Ltd. to bid on providing the nuclear steam supply systems for the third and fourth 680-MW CANDU units at Wolsung. AECL is the only invited bidder.

- AECL supplied Wolsung-1, which is still among the world's top performing reactors and is building a second 680-MW Wolsung unit. The Wolsung-1 unit was built in 61 months and within budget of $\$ 600$ million (1976 Canadian dollars).

- AECL announced the establishment of a program that will see Indonesian engineers and scientists gaining experience at operating CANDU stations.

- The CANDU 600 is one of the candidate reactor designs being considered for the first reactor to be built in Indonesia.

- As a result of current technology transfer, Korea now fabricates its ows. CANDU fuel, and a percentage (at least $60 \%$ ) of locally produced fuel for the Wolsung unit 2 currently under construction.

- $\quad N W 2 / 9 / 92$ also NN 3/92

* Nuclear Plant Joumal Jan-Feb 1992

- The World Nuclear Indistry Handbook December 1991 


\section{VENDOR DATA SHEET}

ORGANIZATION:

AEE

Name

Atomenergoexport

AREA:

Address

Soviet Union

Russia

Phone \#

Fax \#

TYPE/PURPOSE:

SIZE:

HISTORY/LINKAGES:

\section{COMMENTS:}

- AEE submitted a single (December 1991) bid to supply its latest 1000-MW(e) PWR design to Finnish utilities.

- AEE supplied two VVER-440 reactors at IVO's Loviisa power station. 
VENDOR DATA SHEET

ORGANIZATION:

Name Babcock \& Wilcox - Also see FRAMATOME

B\&W

Address

Phone \#

Fax \#

TYPE/PURPOSE:

- Major segment of B\&W is owned by Framatome.

SIZE:

\section{HISTORYRINKAGES:}

- B\&W Fuel Company-49\% Framatome, 51\% B\&W.

B\&W Nuclear Service Company-75\% Framatome, 25\% B\&W.

Plans for Reactor technical company with Framatome, Siemens/KWU.

- The French now (January 1992) have controlling interest in two B\&W Nuclear Technology subsidiaries.

- B\&W Nuclear Technology (BWNT), formerly an unincorporated division of B\&W Company is now a wholly owned corporation of Framatome, U.S.A.

Framatome, through BWNT, increased its ownership in B\&W Co. subsidiary, B\&W Nuclear Services, Inc., from $50 \%$ to $75 \%$.

Virginia Fuel, Inc., which is composed of Framatome, Cogema, and Uranium Peckiney, increased its share of B\&W Fuel Co. (BWFC) from 49 to $75 \%$.

McDermott International, Inc., (w'hich owned 50\% stakes in the B\&W subsidiaries) is in the midst of a financial program to raist; money to pay debts.

By the end of 1993, all of the B\&W commercial companies will be fully owned Framatome subsidaries

\section{COMMENTS:}

- Discussions

- NW $12 / 12 / 91$ 


\section{VENDOR DATA SHEET}

ORGANIZATION:

Name China National Nuclear Corporation

CNNC

Address

AREA:

Phone \#

- Asia

Fax \#

TYPE/PURPOSE:

- Government owned organization.

SIZE:

HISTORY/LINKAGES:

- The Pakistan contract made China a nuclear power exporter $16 \mathrm{~d}$ after it first became a nuclear power producer (December 1991).

\section{COMMENTS:}

- $\quad$ On December 31, 1991, the governments of Pakistan and China ended more than a year of negotiations with a contract under which China will provide a 300-MW(e) PWR to Pakistan. The plant is to be built and operated under IAEA safeguards. No financial agreements were provided. Pakistan has a 125-MW(e) Kanupp pressurized HWR that is nearly 20-years old. The reactor from China will be similar to the 300-MW(e) PWR that went on-line in December 1991 at Qinshan in Zhejiang Province.

- China considers Qinshan-1 to be its own indigenous design, even though much of the hardware was produced in other nations.

* Qinshan-1 was based on technology developed in China for submarine reactors.

४p. 4 Two subsidiary agreements relating to the supply of a 300-MW(e) PWR to Pakistan were formalized. The contracts were signed by Jiang Xinxiong, president of CNNC, and Dr. Ishfaq Ahmed, chairman of Pakistan's Atomic Energy Commission.

๑p. 10 About $70 \%$ of the equipment for Qinshan was fabricated in China. Large components were imported (the vessel from Mitsubishi).

- $\quad N N 2 / 92$

* NW $1 / 2 / 92$

- NEI April 1992 p.4, p.10 


\section{VENDOR DATA SHEET}

ORGANIZATION:

FRAMA

$\begin{array}{ll}\text { Name } & \text { Framatome (also see Babcock \& Wilcox) } \\ \text { Address } & \text { France }\end{array}$

Phone \#

Fax \#

TYPEPURPOSE:

SIZE:

HISTORY/LINKAGES:

- Created in 1958 by decree of the French Government. Previously, this was essentially the Westinghouse operation in France. In 1958, Framatome began activity with a license from Westinghouse on PWR technology.

- In 1981, a new relationship was established wian Westinghouse based on the maturity of French PWR technology.

- Framatome ownership in $1986-40 \%$ CGE, 35\% CEA, 10\% EdF, 12\% DUMEX, 3\%. The organization was offered for sale to the personnel of Framatome.

\section{COMMENTS:}

* Has built 55 currently operating nuclear plants.

- Framatome designs, manufactures, and sells 600-, 900- to 1000-, and 1300-MW(e) plants. They have sold two 1450-MW(e) units.

* Framatome's products are:

- basic design,

- design of key nuclear components,

- manufacturer of key components (reactor vessels [6-8/year], steam generators [18-24/year], pressurizers [8/year], in-core instrumentation [8 systems/year]),

- eluriched uranium fuel assemblies (first core and initial reload), and

- procurement, transportation, erection, testing, and startup.

- Framatome can supply any of the following:

- NSSS (nuclear steam supply system),

- installation and startup of NSSS,

- nuclear islands,

- complete nuclear power plants (in conjunction with industrial partners), and

- nuclear fuel.

- See Nuclear Power International (NPI) a joint venture Siemens \& Framatome.

- Draft of 1986 MIT Report by Beckjord, Golay, Gyftopoulos, Hansen, Lester.

* NN 1992 List of World Plants.

- $N W 10 / 31 / 91$ 
- Chinese agency, quoted by Agence France Presse, reported a delay in the startup of the 900-MW(e) Daya Bay-1 PWR in Guangdong Province near Hong Kong until the summer of 1993. The Daya Bay units are being supplied by Framatome and GEC Alsthom, respectively, with technical project supervision by EdF with Guangdong Nuclear Power Joint Venture Company (a partnership of Hong Kong and Guangdong utilities).

- $\quad$ See association with SKODA and Siemens (SKODA).

- Framatome is expected to bid on two 1000-MW reactors for Taiwan (Taipower 7\&8). ABB$\mathrm{CE}, \mathrm{GE}$, and Westinghouse are also expected to bid. 


\section{VENDOR DATA SHEET}

ORGANIZATION:

GA

Name

General Atomics

Address

California

Phone \#

Fax \#

TYPEPURPOSE:

- General Atomics has been developing the Modular High-Temperature Gas-Cooled reactor. The success of this advanced reactor will determine if it becomes a vendor.

SIZE:

HISTORYIINKAGES:

COMMENTS:

- 1992 is the thirtieth anniversary of the first nuclear chain reaction in Korea. The $100 \mathrm{KW}$ thermal TRIGA (GA) research reactor went critical in 1962 at the Korea Atomic Energy Research Institute in Seoul. Its operation in the 1960s and 1970s helped Korea develop its nuclear knowledge and infrastructure.

- NEI April 1992 p.30 


\title{
VENDOR DATA SHEET
}

ORGANIZATION:

$\begin{array}{ll}\text { Name } & \text { General Electric Company } \\ \text { Address } & \text { Schenectady, NY } \\ & \text { U.S.A. }\end{array}$

Phone \#

Fax \#

\section{TYPE/PURPOSE:}

\author{
- Public Company \\ SIZE: Dollar Volume - $\$ 58.4 \times 10^{9}$ \\ Number of Employees -
}

HISTORY/LINKAGES: - Incorporated 4/15/1892

- Joint ventures SDRC; Quadrex Corp.; Big Three Industries, Inc.; Coherent, Inc.; PPG, with Stone \& Webster with GE - Nuclear Parts Associates \$30M contract with Gulf States Utilities, with Fuji Elec. Co., Strategic Alliance Agreement; with GE of the United Kingdom (an unrelated company) for European business interest, with Turigsram Co., LTD, of Hungary Lighting.

\section{COMMENTS:}

- Decentralized: industry, aerospace, aircraft engineers, appliances, broadcasting, industrial, materials, power systems, technical products and services.

- 177 manufacturing plants in 35 states and Puerto Rico. Some 103 manufacturing plants in 23 other countries.

Welch (Chairman) to shareholders 1990:

Revenues of $\$ 58.4 \mathrm{~B}$ plus contribution to balance of trade of $\$ 4.5 \mathrm{~B}$. R\&D expenditure up $9 \%$ to $\$ 4.3 \mathrm{~B}$ and $\$ 9.9 \%$ of sales record, $20 \%$ of the European lamp business and number one in the world.

- Two new GE nuclear power plants are under construction (groundbreaking September 1991) employing an advanced "evolutionary" design. They are units 6 and 7 at the Kashwazaki Kariwa station 140 miles Northwest of Tokyo. The other five units are also GE BWRs. These plants will be the first 1356-MW(e) advanced boiling water reactors (ABWR). GE is also seeking certification of the ABWR use in the United States (Reference USCEA \#269 10/91). GE claimed they met their goal of 15 to $20 \%$ improvement in overnight capital cost relative to previous BWRs. Operation and maintenance are also expected to be significantly lower. GE's share of the project was $\$ 1.4 B$, which helps the U.S. Japan deficit problem.

- $\quad \mathrm{GE}$ is currently deve.'oping an advanced 600-MW BWR (SBWR). ${ }^{1}$

- The GE SBWR is one of the candidate reactor designs being considered for the first reactor to be built in Indonesia.

- Moody's 1992

1 DOE has 26 million in the '93 Budget for ALWRs (AP600 and SBWR) NN 3/92.

- World Nuclear Industry Handbook December 1991. 
- GE Nuclear Energy and three Japanese manufacturing firms have agreed to extend their 25 year technical cooperation agreements by another 10 years. The Japanese firms are Hitachi, Toshiba, and Japan Nuclear Fuel Company, with the latter jointly owned by GE, Hitachi and Toshiba. The technology collaboration with GE was initiated in 1967. This method of technology exchange gives the participants access to each firm's BWR engineering and manufacturing technical information. Areas for joint R\&D technology collaboration include development, testing, and manufacturing of high performance BWR components, such as nuclear fuel, control rods, and other reactor internals; the creation, qualification, and characterization of new nuclear-grade materials; and the development and evaluation of new analytical models and calculational methods to more accurately simulate and predict BWR performance.

- GE is expected to bid on two 1000-MW reactors for Taiwan (Taipower 7\&8). ABB-CE, Westinghouse and Framatome are also expected to bid.

\section{REACTOR PLANTS}

BWR - numerous BWR in all sizes (1960s, 70s \& 80s)

BWR - [large $\sim 1300$ to $1500 \mathrm{MW}(\mathrm{e})$ (ABWR)]

BWR - [medium $\sim 600 \mathrm{MW}(\mathrm{e})$ (SBWR)]

Government plants

- Nuclear Plant Journal, Jan. - Feb. 1992.

- USCEA INFO, June/July 1992 


\section{VENDOR DATA SHEET}

ORGANIZATION:

HITAC

Name HITACHI, LTD.

Address

Phone \#

Fax \#

\section{TYPE/PURPOSE:}

- Public company.

- Manufacturing and marketing of consumer products, power systems and equipment, information and communication systems, electronic devices, industrial machinery and plants, wire, cable, metals, chemicals, and other products.

SIZE:

- Net sales

- Stockholders

- Employees

- Net income

- Earn per share

- Assets/liabilities

- Long-term debt

- $\quad$ Stock price range

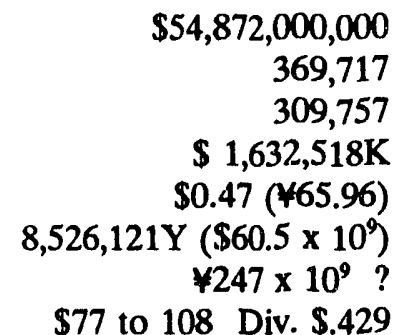

HISTORY/LINKAGES:

- Founded in Japan in 1910 and incorporated in 1920.

- $\quad$ Established Hitachi Data Systems Corporation 1989.

- Founded Advanced Interconnection Technology, Inc., in New York. 1990

- Established Hitachi Electronic Devices (USA) in South Carolina. 1990

- Established Hitachi Home Electronics (America), Inc. 1991

- Established Open System Business Center in America. 1991

- Established Hitachi Computer Products (America) and HCP (Europe) in France. 1991

- Established Hitachi Cable Ltd. in Malaysia. 1991

- Joint Ventures:

- Electronic Data Systems Corporation (Electronic Data 20\%).

- Joint with Deere \& Co. \& Fiat Geotech (hydraulic elevators in the United States and Europe).

- Joint ventures with GE. ${ }^{1}$

- Sixty consolidated subsidiaries.

\section{COMMENTS:}

- Moody's 1992

1 Nuclear Plant Journal, (Jan.-Feb. 1992) 
PRODUCT LINES:

Nuclear equipment

Heavy electric equipment

Electronics

Construction Equipment

Other 


\section{VENDOR DATA SHEET}

ORGANIZATION:

Name Mitsubishi Electric Corporation

Address Denki Bldg., 2-3 Marunouchi

2-Chrome, Chiyoda-Ku, Tokyo 100 Japan

Phone \# (03) 32118-2111
AREA:

MITEC
- 28 locations in Japan

Fax \#

TYPE/PURPOSE:

- Public company.

- Manufacturing and marketing electronic and electrical, information processing, communication, satellite relay and optical fiber equipment.

- Products space development, communication information processing, electronic devices, energy, transportation, building equipment and systems, heavy machinery, industrial equipment, audiovisual and home electronics.

\section{SIZE:}

- Net sales

- Number of employees

- Net income

- Earn per share

- Assets/liabilities

- Long-term debt

- $\quad$ Dividends paid

- Stock authorized

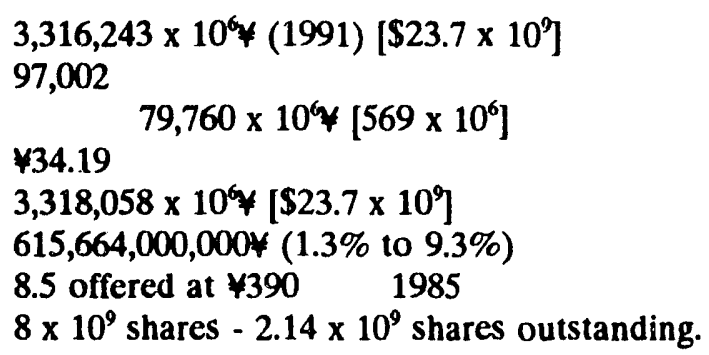

\section{HISTORY/LINKAGES:}

- $\quad$ Established in 1921. Changed to present name in 1963.

- Joint ventures in Mexico, Brazil, Colombia, Venezuela, France, Saudi Arabia, Nigeria, Singapore, Malaysia, Philippines. Korea, United Arab Emirates, Australia, New Zealand and the United States.

- Principle subsidiaries: 19 in Japan, 4 in the United States, 2 in Canada, 1 in the Netherlands, 1 in the United Kingdom, 1 in Singapore, 1 in Germany, and 1 in France.

\section{COMMENTS:}

* The Mitsubishi MS-600 is one of the candidates for the first reactor design to be used in Indonesia.

\section{- $\quad$ Moody's, 1992}

- World Nuclear Industry Handbook, December 1991 


\section{VENDOR DATA SHEET}

ORGANIZATION:

Name

Address

Phone \#

Fax \#

TYPE/PURPOSE:

- A subsidiary of Kansi Electric Power Company

SIZE:

HISTORY/LINKAGES:

\section{COMMENTS:}

- NJEC will conduct a feasibility study for a possible nuclear power plant in the Muria Peninsula region of Indonesia to be completed in 1993. Contracts may be awarded in 1996-1997. Next step will be geological and environmental studies to be completed by March 1996. Indonesia projects a need for $3,500 \mathrm{MW}(\mathrm{e})$ and generation of $7,500 \mathrm{MW}$ by nuclear power. 


\section{VENDOR DATA SHEET}

ORGANIZATION:

Name

Nuclear Power International

NPI

Address

Phone \#

Fax \#

\section{TYPE/PURPOSE:}

- A joint venture of Siemens and Framatome.

SIZE:

\section{HISTORY/LINKAGES:}

\section{COMMENTS:}

- NPI is offering 1110-MW and 1380-MW PWR designs for the Loviisa site and BWRs of the same size for the Olkilnoto Finnish System. One ton of documentation was delivered to the utilities for each alternative. NPI believes that $50 \%$ is construction work that can be performed by the Finns. NPI has studied 45 Finnish companies for possible partnerships. The former Soviet Union's Atomenergoerport (AEE) is also competing with a 1040-MW PWR.

* Sites will be selected in Germany and France in 1994 for construction of an advanced PWR designed by NPI. Construction of one reactor could get underway in each country by 1998. The utility consortium led by EdF have agreed on a large evolutionary type reactor of about 1500-MW. The extent of the utilities contribution to the design is still to be resolved. Basic design phase in 1993-94 will include all design documentation independent of the site. Forum in Ronn said that NPI is confident that "licensing applications for the plant will be placed simultaneously in Germany and France in mid-1995."

* Design features of the NPI are to include: simpler instrumentation and controls, prestressed concrete cylindrical containment with steel lines, and the spent-fuel pool in the annular building surrounding the outer containment. NPI has rejected most passive safety approaches, but some are used in the secondary side of the new PWR, including a new safety condenser for decay heat removal. How much of the design role the vendor is willing to relinquish to EdF and its utility associates is not clear. EdF is not prepared to accept the "failures" that utilities have paid for due to lack of close control of nuclear plant construction in America.

- NPI has formed a Finnish subsidiary to promote its bid for building a fifth nuclear reactor in Finland.

- Summary of NPI design concept stressed the use of a safety condenser, an evolutionary approach ("four-train" concept using four fully separated safety systems without headers), and material with high embrittlement resistance for the vessel that will retain its ductility throughout the life of the unit.

- $\quad N W 10 / 31 / 91$

* $\quad N W 02 / 106 / 92$

- $\quad N W 03 / 05 / 92$

- NEI 4/92 


\section{VENDOR DATA SHEET}

ORGANIZATION:

$\begin{array}{ll}\text { Name } & \text { Siemens AG } \\ \text { Address } & \begin{array}{l}\text { Wittelsbacher 2 D-8000 } \\ \text { Mantch 2 }\end{array} \\ & \begin{array}{l}\text { Germany } \\ \text { Phone \# }\end{array} \\ \text { Fax \# } & \text { (089) 234-0 } \\ & 52100-0\end{array}$

SIEME

Siemens Power Corporation

P. O. Box 90777

Bellevue, WA 98009-0777

U.S.A.

\section{TYPE/PURPOSE:}

- Public company

- Engaged in the entire field of electrical engineering and electronics.

- Manufacturing and marketing of components, communication and information systems, power engineering and automatron, telecommunications and security systems, and medical engineering.

SIZE:

- Employees

- Net sales

- Net income

- Assets/liabilities

- Long-term debt

- $\quad$ Stock Range $\$ 65$ to 94
$353,000-1989$

$61.1 \times 10^{9} \mathrm{DM}$

$1.58 \times 10^{9} \mathrm{DM}$

$64.4 \times 10^{9} \mathrm{DM}$

$4.22 \times 10^{9} \mathrm{DM}$ (4.75 to $\left.15 \%\right)$

1990 dividends $\$ 1.071$

\section{HISTORY/LINKAGES:}

- Siemens and Halske AG 1847

- Acquired remaining 50\% of Kraftwork Union in 1977

\section{COMMENTS:}

* Siemens has consolidated its U.S. power generating products and services into one operating company (Siemens Power Corporation). These products and services include fossil, gas turbines, generators, nuclear services and fuel, and related electrical components. It will also hold the U.S. interest in the remaining Siemens KWU affiliates. For 20 years, these affiliates were part of Advanced Nuclear Fuel Corp. prior to being bought by Siemens KWU.

- Siemens AG's Power Generation Group (KWU) will provide instrumentation and controls for Mochovce Units $3 \& 4$ in Czecho-Slovakia.

Siemens Power Corporation has joint operations with Czech Works.

- See Nuclear Power International (NPI) joint venture Siemens and Framatome.

1 See discussion on SKODA vendor sheet regarding Siemens joint venture with Skoda and Framatome.

* $\quad$ NN 2/92 pages $83,84,86$

- Moody's

- $\quad N W 10 / 31 / 91$

$1 \quad N W 12 / 5 / 91$ 


\title{
VENDOR DATA SHEET
}

ORGANIZATION:

SKODA

\author{
Name Skoda Energy \\ Address Czechoslovakia \\ Phone \# \\ Fax \# \\ TYPE/PURPOSE:
}

SIZE:

- $\quad$ Skoda Pilsen $37 \times 10^{3}$ employees 1990 (1,937 engaged in nuclear division work).

- $\quad$ Sales $\$ 3.3 \times 10^{6}$ for nuclear division $0.8 \%$ of total Skoda Pilsen sales.

- Turbine sales accounted for $6.3 \%$ of total sales.

- $\quad$ Sales in 1991 maybe $50 \%$ of 1990 sales.

\section{HISTORY/LINKAGES:}

- Skoda Concern, Pilsen, and Siemens AG's KWU formed (fall 1991) a joint venture partnership in nuclear, fossil, and hydroelectric generating equipment (Skoda 33\%, Siemens 67\%).

- $\quad$ Framatome will acquire $10 \%$ of the Siemens share leaving Siemens with $57 \%$.

\section{COMMENTS:}

- $\quad$ Skoda Energy is seen in Germany as giving Siemens a decided edge in future nuclear equipment competition in Eastern Europe, including any new Western PWRs the Czechs may order for the Temelin site where two Soviete-design VVER-1000s are awaiting completion.

- Framatome said this agreement does not change the plans for NPI. The new company's nuclear business is expected to be small. Its prime work will be modernization of fossil-fired plants.

- $\quad$ Skoda, long a key supplier of heavy components for Soviet PWRs, began the search for a Western partner in early 1990 . Czechs considered Westinghouse, Framatome, Siemens, GE, and $\mathrm{ABB}$ before joining Siemens.

- The joint venture is expected to assure Siemens a major role in upgrading as many as sixteen Czechoslovakian PWRs that are either operating or under construction.

- Since Skoda is the most important power equipment supplier in the country, which has the regions largest nuclear infrastructure. This venture should give the German vendor an advantage in marketing power equipment in Eastern Europe.

$\Delta \quad$ Western and Far Eastern vendors have a new competitor "Skoda Pilsen." SKODA has received certification from ASME. The ASME certification guarantees that their products meet the high quality demanded by nuclear operators and licensing authorities in the West. According to its statement, SKODA chose Siemens (and Framatome) as partners not only to maintain high technical standards for the domestic nuclear plants in Northern Bohemia, but also to help the company meet international standards that will allow it to participate in the world market. Skoda has 7,000 people in this field.

- $N W 12 / 05 / 91$

- Nuclear Energy INFO May 1992

- Nuclear News January 1992 


\section{VENDOR DATA SHEET}

ORGANIZATION:

Name

Address

Phone \#

Fax \#
TOSHIBA Machine Company № 2-11, Gunza 4-Chome Chus-Ku

Tokyo 104 Japan

03-567-0511

03-535-2570

TOSHI

\section{TYPE/PURPOSE:}

- Public stock.

- Engaged in machinery, plastics, semiconductor manufacturing equipment, electric controls, and food service equipment.

- Nine major subsidiaries and joint ventures.

SIZE (as of 1989):

- Number of employees

AREA:

- Nuzamu

- Sazami

- Gotemba

- Net sales

3,300 ?

- Net earnings $\$ 824 \times 10^{6}$

- Earnings per common share $\$ 11.1 \times 10^{6}$

- Assets/liabilities

- Long-term debt

$\$ 3.75$

$\$ 912 \times 10^{6}$

- Number of stockholders $\$ 5,289,000,000$

13,860

HISTORY/LINKAGES:

- $\quad$ Established in Japan in 1938.

COMMENTS:

\section{PRODUCT LINES:}

Nuclear equipment and electronics. 


\section{VENDOR DATA SHEET}

ORGANIZATION:

Name

Westinghouse Electric Corporation

Address

Phone \#

Fax \#

\section{TYPE/PURPOSE:}

- Public company.

- Manufacturing and marketing of electrical equipment, power generating equipment, transmission equipment, waste management systems, instrumentation, fuel cells, solar power elements.

\section{SIZE:}

HISTORY/LINKAGES: France - Framatome

Japan - Mitsubishi

- Designers and builders of the first AC machinery in the late $1800 \mathrm{~s}$.

- Designers and builders of the reactor for the first nuclear submarine in the 1950 s.

- Designers and builders of the first nuclear power plant in the 1950s.

- Licensed Framatome to build the W PWRs in the 1960s.

\section{COMMENTS:}

- Currently developing an advanced 600-MW(e) PWR (AP600) ${ }^{1}$ with active NRC licensing work and interaction.

* W has reached an agreement to proceed with putting PNNI [620 MW(e)] on line in 1995 and pay $\$ 100 \mathrm{M}$ in cash and services to the Philippines.

- Working agreement with Mitsubishi in 1992.

- The AP600 is one of the candidates for the first reactor design to be used in Indonesia.

$\Delta$ Dozens of engineers from Indonesia, Italy, and Spain are in Pittsburgh working on the AP-600. In addition, nuclear companies in France, Japan, and Spain have committed money to the design (in the millions \$). W also has "serious expression of interest" in the AP-600 from Poland, Mexico, South Korea, Argentina, Bulgaria, and Egypt.

- A Business Week article last November claimed that a Senior Management Group, including Lego ( $\underline{W}$ president), went to Tokyo to renegotiate licensing agreements with Mitsubishi and also (according to a source involved in the talks) explored the idea of selling Mitsubishi the whole company for a premium of $20 \%$ over its $\$ 3.7$ billion book value. $\underline{\mathrm{W}}$ denies such talks ever took place.

- General information.

1 DOE has 26 million in 1993 Budget for AP600 and SBWR NN, 3/92.

* USCEA INFO, 3/92.

- World Nuclear Industry Handbook, December 1991.

$\triangle \quad$ Nuclear Energy INFO, May 1992

- Business Week, May 11, 1992 
W president (Lego) sent a letter to Business Week stating that the allegations made in their May 11 article are incorrect and irresponsible.

$\checkmark \underline{W}$ is expected to bid on two 1000-MW reactors for Taiwan (Taipower $7 \& 8$ ). ABB-CE, GE, and Framatome are also expected to bid.

^ In $1991 \mathrm{~W}$ 's APWR 1300 earned its preliminary design authorization from the NRC. Developed with the aid of funding from Japanese utilities, it will be Japan's next PWR project. An APWR 1000 has also been developed.

\section{REACTOR PLANTS:}

PWR - Numerous PWRs in all sizes built in 1950s, bulb \& 70 s.

Government Plants - Hanford, Savannah River, Idaho

New Designs - Large Evolutionary LWR

- Medium Advanced LWR, AP-600

- Letter from Lego, W President, to Business Week

$\checkmark$ USCEA INFO, June/July 1992

× Nuclear Engineering International, May 1992, p. 52 
Appendix B. REACTOR PRODUCTS 


\section{Appendix B. PRODUCT DATA SHEETS}

\section{B.1 INTRODUCTION}

This appendix provides the detailed technical characteristics of each reactor product. The product data sheets are ordered alphabetically by product name within each design class. Each product data sheet is divided into two parts: general product characteristics and technical product characteristics.

The general product characteristics were summarized earlier in Table 4.1. The technical product characteristics include the reactor thermal and electrical power, coolant temperatures, fuel design parameters, power density, fuel-cycle length, steam generator design, safety system descriptions, plant design life, construction time, and other pertinent product characteristics. 


\section{PRODUCT DATA SHEET}

\section{GENERAL CHARACTERISTICS}

Product Name: Advanced Boiling-Water Reactor

Reactor Type: BWR

Electrical Power: $1356 \mathrm{MW}(\mathrm{e})$

Design Type: Evolutionary Plant

Developmental Status: Construction

Availability: Current

\section{Vendor oreanization:}

- General Electric, U.S.A.

- Hitachi, Ltd., Japan

- Toshiba Corporation, Japan

\section{Utilities using product:}

- Tokyo Electric Power Co., Inc. (TEPCO)

.

\section{Steam Generator Design:}

SG type: N/A

No. of SGs: N/A

Electrical power: $1356 \mathrm{MW}(\mathrm{e})$

Coolant inlet temp: $216^{\circ} \mathrm{C}$

Coolant outlet temp: $288^{\circ} \mathrm{C}$

\section{Fuel Design:}

Fuel composition: $\mathrm{UO}_{2}$

Fuel enrichment:

Array size: $8 \times 8$ or $9 \times 9$

No. of fuel assemblies: 872

Core loading (MTU):

Av fuel burnup:

Power density: $50.6 \mathrm{~kW} / \mathrm{L}$

Operating cycle: 18 months

Safety System Design:

Containments: lined, reinforced concrete with pressure suppression

ECCS design: high \& low pressure injection plus passive injection

List of unique safety systems: no external recirculation piping, RHR system

Scheduling:

Construction time: 48 months

Construction cost:

Plant design life:

Comments: TEPCO has ordered two units, currently under construction, at the Kashiwazaki-Kariwa Nuclear Power Station 140-miles NW of Tokyo with commercial operation set for 1996 and 1997, respectively.

References: GE Advanced Boiling Water Reactors, D. R. Wilkins, GE Nuclear Energy, April 1990.

Nuclear News, "The New Reactors," Vol. 35, 12, pg. 65-90, September 1992. 


\section{PRODUCT DATA SHEET}

\section{GENERAL CHARACTERISTICS}

Product Name: Advanced Boiling-Water Reactor 90

Reactor Type: BWR

Electrical Power: $1050 \mathrm{MW}(\mathrm{e})$

Design Type: Evolutionary Plant

Developmental Status: Design

Availability: Current

Vendor organization:

ABB-Atom

-

-

\section{TECHNICAL CHARACTERISTICS}

Reactor:

Thermal power: $3020 \mathrm{MW}(\mathrm{t})$

Electrical power: $1050 \mathrm{MW}(\mathrm{e})$

Coolant inlet temp: $215^{\circ} \mathrm{C}$

Coolant outlet temp: $286^{\circ} \mathrm{C}$

\section{Fuel Design:}

Fuel composition: $\mathrm{UO}_{2}$

Fuel enrichment:

Array size:

No. of fuel assemblies: 676

Core loading (MTU): 120

Av fuel burnup:

Power density: $50 \mathrm{~kW} / \mathrm{L}$

Operating cycle:
Utilities using product:

Steam Generator Design:

SG type: N/A

No. of SGs: N/A

\section{Safety System Design:}

Containments: steel primary with reinforced concrete secondary

ECCS design: four independent systems List of unique safety systems: containment venting and forced flooding

\section{Scheduling:}

Construction time: $<57$ months

Construction cost:

Plant design life:

Comments: Basis for commercial bid to Finnish power companies. The ABWR 90 is a moderate design modification of the two existing plants, Forsmark 3 and Oskarshamn 3, in Sweden.

References: BWR 90 - The Advanced Alternative, ABB Atom, 1988. 


\section{PRODUCT DATA SHEET}

\section{GENERAL CHARACTERISTICS}

Product Name: Advanced Pressurized-Water Reactor

Reactor Type: PWR

Electrical Power: $1050 \mathrm{MW}(\mathrm{e})$

Design Type: Evolutionary Technology

Developmental Status: Design

Availability: Preliminary design in July 1993

Vendor organization:

- Westinghouse, U.S.A.

- Mitsubishi, Japan

-

\section{TECHNICAL CHARACTERISTICS}

\section{Reactor:}

Thermal power: $3150 \mathrm{MW}(\mathrm{t})$

Electrical power: $1050 \mathrm{MW}(\mathrm{e})$

Coolant inlet temp: $287^{\circ} \mathrm{C}$

Coolant outlet temp: $325^{\circ} \mathrm{C}$

\section{Fuel Design:}

Fuel composition: $\mathrm{UO}_{2}$

Fuel enrichment:

Array size: $17 \times 17$

No. of fuel assemblies: 193

Core loading (MTU):

Av fuel burnup:

Power density: $96.2 \mathrm{~kW} / \mathrm{L}$

Operating cycle: 17 months
Utilities using product:

\author{
Steam Generator Design: \\ SG type: \\ No. of SGs: 3 \\ Safety System Design: \\ Containments: Cylindrical steel \\ ECCS design: \\ List of unique safety systems: \\ Scheduling: \\ Construction time: \\ Construction cost: \\ Plant design life:
}

Comments: Zircaloy-4 cladding. Design work on larger APWR 1300 is under way and includes $1300 \mathrm{MW}(\mathrm{e}), 3900 \mathrm{MW}(\mathrm{t}), 19 \times 19$ fuel assembly array size with similar coolant temperatures and four steam generators.

References: Nuclear News, "The New Reactors," Vol. 35, 12, pg. 65-90, September 1992. 


\section{PRODUCT DATA SHEET}

\section{GENERAL CHARACTERISTICS}

Product Name: CAINDU 3

Reactor Type: HWR

Electrical Power: $450 \mathrm{MW}(\mathrm{e})$

Design Type: Evolutionary Plart

Developmental Status: Design

Availability: Current

\section{Vendor organization:}

AECL, Canada

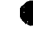

8

\section{TECHNICAL CHARACTERISTICS}

\section{Reactor:}

Thermal power: $1440 \mathrm{MW}(\mathrm{t})$

Electrical power: $450 \mathrm{MW}(\mathrm{e})$

Coolant inlet temp: $260^{\circ} \mathrm{C}$

Coolant outlet temp: $310^{\circ} \mathrm{C}$

\section{Fuel Design:}

Fuel composition: $\mathrm{UO}_{2}$ Fuel enrichment: natural Array size: 37-element bundle No. of fuel assemblies: 232 Core loading (MTU): 53.2 Av fuel burnup:

Power density: $12.8 \mathrm{~kW} / \mathrm{L}$ Operating cycle: continuous, online refueling.

\section{Utilities using product:}

- Canada

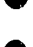

\section{Steam Generator Design:}

SG type: vertical U-tube with integral steam drum and preheater

No. of SGs: 2

\section{Safety System Design:}

Containments: dual containment carbon steel liner inside reinforced concrete building ECCS design: passive high-pressure injection

List of unique safety systems: PCCS, PRHR

Scheduling:

Construction time: 38 months

Construction cost:

Plant design life: 40 years

Comments: Heavy water moderator and coolant. Core loading was calculated as 232 fuel channels x 12 fuel bundles/channel x $19.1 \mathrm{KgU} /$ bundle x $1 \mathrm{MT} / 1000 \mathrm{Kg}=53.2 \mathrm{MTU}$. Zircaloy-4 cladding.

References: CANDU 3-The Right Product for the Times, Atomic Energy of Canada Limited.

Nuciear News, "The New Reactors," Vol. 35, 12, pg. 65-90, September 1992. 


\section{PRODUCT DATA SHEET}

\section{GENERAL CHARACTERISTICS}

Product Name: CANDU 6

Reactor Type: HWR

Electrical Power: $665 \mathrm{MW}(\mathrm{e})$

Design Type: Evolutionary Plant

Developmental Status: In use

Availability: Current

Vendor organization:

Utilities using product:

AECL, Canada

- Canada

-

- KEPCO, Korea

\section{TECHNICAL CHARACTERISTICS}

Reactor:

Thermal power:

Electrical power: $665 \mathrm{MW}(\mathrm{e})$

Coolant inlet temp:

Coolant outlet temp:

\section{Fuel Design:}

Fuel composition: $\mathrm{UO}_{2}$

Fuel enrichment: natural

Array size: 37-element bundle

No. of fuel assemblies: 380

Core loading (MTU):

Av fuel burnup:

Power density:

Operating cycle: continuous, on-

line refueling
Steam Generator Design:

SG type: vertical U-tube

No. of SGs: 4

\section{Safety System Design:}

Containments:

ECCS design:

List of unique safety systems:

Scheduling:

Construction time:

Construction cost:

Plant design life:

Comments: AECL, has sold 12 of the CANDU 6 reactors in Canada, South Korea, Argentina and Romania. Heavy water moderator and coolant.

References: Nuclear Engineering International, Vol. 35, 430, pg. 22-25, May 1990. The Energy Daily, pg. 1, September 1992. 


\section{PRODUCT DATA SHEET}

\section{GENERAL CHARACTERISTICS}

Product Name: N4

Reactor Type: PWR

Electrical Power: $1528 \mathrm{MW}(\mathrm{e})$

Design Type: Evolutionary Plant

Developmental Status: In use

Availability: Current

Vendor organization:

- Framatome, France

-

\section{TECHINICAL CHARACTERISTICS}

Reactor:

Thermal power: $4270 \mathrm{MW}(\mathrm{t})$

Electrical power: $1528 \mathrm{MW}(\mathrm{e})$

Coolant inlet temp: $292^{\circ} \mathrm{C}$

Coolant outlet temp: $330^{\circ} \mathrm{C}$

\section{Fuel Design:}

Fucl composition: $\mathrm{UO}_{2}$

Fuel enrichment: $1.5 \%, 2.4 \%$, 2.95\%

Array size:

No. of fuel assemblies: 205

Core loading (MTU):

Av fuel burnup: $36000 \mathrm{MWd} / \mathrm{MT}$

Power density: $44.8 \mathrm{~kW} / \mathrm{m}$

Operating cycle:
Utilities using product:

- EdF, France

-

\section{Steam Generator Design:}

SG type: vertical U-tube

No. of SGs: 4

\section{Safety System Design:}

Containments: dual, prestressed concrete ECCS design:

List of unique safety systems:

\section{Scheduling:}

Construction time:

Construction cost:

Plant design life:

Comments: Chooz B in the Ardennes region of France was the first model N4 series of French nuclear reactors.

References: Nuclear Engineering International, Vol. 30, 365, pg. 26-32, February 1985. 


\section{PRODUCT DATA SHEET}

\section{GENERAL CHARACTERISTICS}

Product Name: Sizeweil B

Reactor Type: PWR

Electrical Power: $1250 \mathrm{MW}(\mathrm{e})$

Design Type: Evolutionary Plant

Developmental Status: Construction

Availability: Current

Vendor organization:

- Westinghouse, USA

- NNC, Great Britain

-

\section{TECHNICAL CHARACTERISTICS}

\section{Reactor:}

Thermal power: $3411 \mathrm{MW}(\mathrm{e})$

Electrical power: $1250 \mathrm{MW}(\mathrm{c})$

Coolant inlet temp: $294^{\circ} \mathrm{C}$

Coolant outlet temp: $326^{\circ} \mathrm{C}$

\section{Fuel Design:}

Fuel composition: $\mathrm{UO}_{2}$

Fuel enrichment: $2.1 \%, 2.6 \%$, $3.1 \%$

Array size:

No. of fuel assemblies: 193

Core loading (MTU):

Av fuel burnup: $33000 \mathrm{MWd} / \mathrm{MT}$

Power density: $41.3 \mathrm{~kW} / \mathrm{m}$

Operating cycle:
Utilities using product:

- Nuclear Electric (UK)

-

-

\section{Steam Generator Design:}

SG type: vertical U-tube

No. of SGs: 4

\section{Safety System Design:}

Containments: dual, steel-lined concrete ECCS design: accumulators, RHR pumps List of unique safety systems: containment spray/fan, emergency boration system

Scheduling:

Construction time: 5 years

Construction cost:

Plant design life:

\section{Comments:}

References: Nuclear Engineering International, Vol. 37, 454, pg. 53, May 1992. "The British PWR," Nuclear Engineering International Special Publications, 1988. 


\section{PRODUCT DATA SHEET}

\section{GENERAL CHARACTERISTICS}

Product Name: SNERDI PWR

Reactor Type: PWR

Electrical Power: 300 MW(e)

Design Type: Evolutionary Plant

Developmental Status: In-use

Availability: Current

Vendor organization:

Utilities using product:

China National Nuclear Co.

- MNI, China

-

?

\section{TECHNICAL CHARACTERISTICS}

Reactor:

Thermal power: $966 \mathrm{MW}(\mathrm{t})$

Electrical power: $300 \mathrm{MW}(\mathrm{e})$

Coolant inlet temp: $289^{\circ} \mathrm{C}$

Coolant outlet temp: $315^{\circ} \mathrm{C}$

\section{Fuel Design:}

Fuel composition: $\mathrm{UO}_{2}$

Fuel enrichnent:

Array size:

No. of fuel assemblies: 121

Core loading (MTU):

Av fuel burnup:

Power density:

Operating cycle:
Steam Generator Design:

SG type: U-tube design

No. of SGs: 1

Safety System Design:

Containments:

ECCS design:

List of unique safety systems:

Scheduling:

Construction time: 6.5 years

Construction cost:

Plant design life:

Comments: First reactor started operation on December 15, 1991, and is located at Qinshan, 100 km from Shanghai. Designed by Shanghai Nuclear Engineering Research and Design Institute (SNERDI).

References: Nuclear Engineering International, Vol. 37, 453, pg. 39-41, April 1992. Nuclear Engineering International, Vol. 37, 454, pg. 53, May 1992.

Nuclear Engineering International, Vol. 37, 455, pg. 38-39, June 1992. 


\section{PRODUCT DATA SHEET}

\section{GTNERAL CHARACTERISTICS}

Product Name: System 80/80+

Reactor Type: PWR

Electrical Power: $1345 \mathrm{MW}(\mathrm{e})$

Design Type: Evolutionary Plant

Developmeztal Status: Construction

Availability: Current, U.S. NRC design certification in 1994.

Vendor organization:

- ABB-CE, USA

-

-

\section{TECHNICAL CHARACTERISTTCS}

Reactor:

Thermal power: $3817 \mathrm{MW}(\mathrm{t})$

Electrical power: $1345 \mathrm{MW}(\mathrm{e})$

Coolant inlet temp: $292^{\circ} \mathrm{C}$

Coolant outlet temp: $324^{\circ} \mathrm{C}$

Fuel Design:

Fuel composition: $\mathrm{UO}_{2}$ or $\mathrm{PuO}_{2}$

Fuel enrichment: $3.3,2.8$, and

$1.9 \%$

Array size: $16 \times 16$

No. of fuel assemblies: 241

Core loading: $116.6 \mathrm{MT} \mathrm{UO}_{2}$

Av fuel burnup:

Power density: $95.5 \mathrm{~kW} / \mathrm{L}$

Operating cycle: 18 to 24 months
Utilities using product:

- Korea Electric Power Co.

?

\section{Steam Generator Design:}

SG type:

No. of SGs: 2

Safety System Design:

Containments: dual, steel sphere inside reinforced concrete building

ECCS design:

List of unique safety systems: PCCS

Scheduling:

Construction time: 48 months

Construction cost:

Plant design life:

Comments: Korea Electric Power Co. has reactor projects in Yongwang and Ulchin, Korea. Zircaloy-4 cladding.

References: System 80+ Standard Design, "THE Nuclear Option for the 90s . ..", ABBCE, Inc., 1991.

Nuclear Engineering International, Vol. 37, 453, pg. 49-50, April 1992.

Nuclear News, "The New Reactors," Vol. 35, 12, pg. 65-90, September 1992. 


\section{PRODUCT DATA SHEET}

\section{GENERAL CHARACTERISTICS}

Product Name: Advanced Passive-600

Reactor Type: PWR

Electrical Power: $600 \mathrm{MW}(\mathrm{e})$

Design Type: Evolutionary Technology

Developmental Status: Design

Availability: U. S. NRC design certification in November 1994

Vendor organization:

Westinghouse Electric Co, U.S.A.

Utilities using product:

.

\section{TECHINICAL CHARACTERISTICS}

Reactor:

Thermal power: $1812 \mathrm{MW}(\mathrm{t})$

Electrical power: $600 \mathrm{MW}(\mathrm{e})$

Coolant inlet temp: $276^{\circ} \mathrm{C}$

Coolant outlet temp: $312^{\circ} \mathrm{C}$

\section{Fuel Design:}

Fuel composition: $\mathrm{UO}_{2}$

Fuel enrichment:

Array size: $17 \times 17$ WE OFA

No. of fuel assemblies: 145

Core loading (MTU): 61.0

Av fuel burnup:

Power density: $78.8 \mathrm{~kW} / \mathrm{L}$

Operating cycle: 18 or 24 months

\section{Steam Generator Design:}

SG type: Westinghouse Model F-1000, vertical U-tube type

No. of SGs: 2

\section{Safety System Design:}

Containments: steel primary with reinforced concrete secondary

ECCS design: high \& low pressure borated coolant injection

List of unique safety systems: PCCS, ADS, passive containment spray, containment

flooding with long-term, passive, RHR

\section{Scheduling:}

Construction time:

Construction cost:

Plant design life:

Comments: Zircaloy decladding.

References: The Energy Daily, pg. 3, April 23, 1992.

Conway, L. E., Westinghouse Electric Company, "Westinghouse AP600 Passive Safety Systems-Key to a Safer, Simplified PWR," American Nuclear Society International Topical Meeting $\neg$ Safety of Next Generation Power Reactors, Seattle, Washington, May 1-5, 1988. Nuclear News, "The New Reactors," Vol. 35, 12, pg. 65-90, September 1992. 


\title{
PRODUCT DATA SHEET
}

\section{GENERAL CHARACTERISTICS}

Product Name: CAREM

Reactor Type: PWR

Electrical Power: $150 \mathrm{MW}(\mathrm{e})$

Design Type: Evolutionary Technology

Developmental Status: Research

Availability: TBD

Vendor organization:

Utilities using product:

- INVAP, Argentina

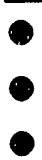

\section{TECHNICAL CHARACTERISTICS}

\section{Reactor:}

\section{Steam Generator Design:}

Thermal power:

Electrical power: $150 \mathrm{MW}(\mathrm{e})$

Coolant inlet temp:

Coolant outlet temp:

SG type: Once-through, helical tube

No. of SGs: 1

\section{Safety System Design:}

Containments: steel vessel

\section{Fuel Design:}

Fuel composition: $\mathrm{UO}_{2}$

Fuel enrichment:

ECCS design: actively initiated, passively operated water injection system

Array size:

No. of fuel assemblies:

Core loading (MTU):

List of unique safety systems: PCCS

Av fuel burnup:

Power density:

Operating cycle:

\author{
Scheduling: \\ Construction time: \\ Construction cost: \\ Plant design life:
}

Comments: Modular reactor design, factory fabrication, preassembled and tested reactor modules. General Atomics and state-owned Investigaciones Aplicadas (INVAP) of Argentina have memorandum of understanding for nuclear research.

References: INVAP, 1991. "CAREM Aims to Make Very-Low-Power Reactors Economic," Nucl. Eng. International, April 1991, 49-51.

Nucleonics Week, 1992. "General Atomics, INVAP Explore Research Reactor, Nuclear Ties.", pg. 15, April 2, 1992. 


\title{
PRODUCT DATA SHEET
}

\section{GENERAL CHARACTERISTICS}

Product Name: European Pressurized-Water Reactor

Reactor Type: PWR

Electrical Power: $1450 \mathrm{MW}(\mathrm{e})$

Design Type: Evolutionary Technology

Developmental Status: Design

Availability: Final design in 1998

Vendor organization:

- Nuclear Power International

- Framatome, France

- Siemens, Germany

\section{TECHNICAL CHARACTERISTICS}

\section{Reactor:}

Thermal power: $4250 \mathrm{MWT}$

Electrical power: $1450 \mathrm{MWe}$

Coolant inlet temp: $291^{\circ} \mathrm{C}$

Coolant outlet temp: $325^{\circ} \mathrm{C}$

\section{Fuel Design:}

Fuel composition: $\mathrm{UO}_{2}$

Fuel enrichment:

Array size: $17 \times 17$

No. of fuel assemblies: 205

Core loading (MTU):

Avg fuel burnup:

Power density: $107 \mathrm{~kW} / \mathrm{L}$

Operating cycle: 12 to 18 months

\section{Utilities using product:}

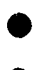

\author{
Steam Generator Design: \\ SG type: \\ No. of SGs: 4 \\ Safety System Design: \\ Containments: steel primary with reinforced \\ concrete secondary \\ ECCS design: high \& low pressure borated \\ coolant injection \\ List of unique safety systems: PRHR, PCCS \\ Scheduling: \\ Construction time: \\ Construction cost: \\ Plant design life:
}

Comments: Successor of the French N4 Reactor and the Konvoi plants in Germany. Zircaloy cladding.

References: Nuclear Engineering International, Vol. 37, 453, pg. 48-49, April 1992. NN, Vol. 35, No. 10, Aug. 1992, pg. 52-53.

Nuclear News, "The New Reactors," Vol. 35, 12, pg. 65-90, September 1992. 


\section{PRODUCT DATA SHEET}

\section{GENERAL CHARACTERISTICS}

Product Name: Hitachi Small Boiling-Water Reactor

Reactor Type: BWR

Electrical Power: $600 \mathrm{MW}(\mathrm{e})$

Design Type: Evolutionary Technology

Developmental Status: Design

Availability: TBD

\section{Vendor organization:}

- Hitachi, Ltd, Japan

-

Utilities using product:

\section{TECHNICAL CHARACTERISTICS}

Reactor:

Thermal power: $1800 \mathrm{MWt}$

Electrical power: $600 \mathrm{MWe}$

Coolant inlet temp:

Coolant outlet temp:

\section{Fuel Design:}

Fuel composition: $\mathrm{UO}_{2}$

Fuel enrichment: $3.6 \%$

Array size: $8 \times 8$

No. of fuel assemblies: 708

Core loading (MTU):

Av fuel burnup: $39,000 \mathrm{MWd} / \mathrm{MT}$

Power density: $34.2 \mathrm{~kW} / \mathrm{L}$

Operating cycle: 23 months
Steam Generator Design:

SG type: N/A

No. of SGs: N/A

Safety System Design:

Containments: steel vessel

ECCS design: natural circulation

List of unique safety systems: steam-driven reactor core isolation cooling, suppression pool, ADS, PCCS

Scheduling:

Construction time: 36 months

Construction cost:

Plant design life:

\section{Comments:}

References: Kataoka, Y., Suzuki, H., Murase, M., Sumida, I., Horiuchi, T., Mike, M., 1988. "Conceptual Design and Thermal-Hydraulic Characteristics of Natural Circulation Boiling Water Reactors," Nucl. Technol., 82:147-156. 


\section{PRODUCT DATA SHEET}

\section{GENERAL CHARACTERISTICS}

Product Name: Mitsubishi Simplified Pressurized-Water Reactor

Reactor Type: PWR

Electrical Power: 600/1200 MW(e)

Design Type: Evolutionary Technology

Developmental Status: Design

Availability: TBD

\section{Vendor organization:}

- Mitsubishi Heavy Industries, Japan

?

\section{TECHNICAL CHARACTERISTICS}

\section{Reactor:}

Thermal power: $1825 / 3650 \mathrm{MW}(\mathrm{t})$

Electrical power: $600 / 1200 \mathrm{MW}(\mathrm{e})$

Coolant inlet temp: $291^{\circ} \mathrm{C}$

Coolant outlet temp: $325^{\circ} \mathrm{C}$

\section{Fuel Design:}

Fuel composition: $\mathrm{UO}_{2}$

Fuel enrichment:

Array size: $15 \times 15$ (MS-500)

No. of fuel assemblies: 157 (MS-

600)

Core loading (MTU):

Av fuel burnup:

Power density:

Operating cycle: 24 months
Utilities using product:

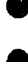

Steam Generator Design:

SG type: horizontal, U-tube

No. of SGs: 2

Safety System Design:

Containments: steel primary with concretefilled, steel secondary

ECCS design: active and passive water injection systems, natural coolant circulation List of unique safety systems: PCCS, ADS, gravity-feed containment flooding

\section{Scheduling:}

Construction time:

Construction cost:

Plant design life:

Comments: Includes data for both MS-600 and MS-1200 designs. Horizontal steam generators provide significant improvements in natural coolant circulation \& prevention of crud buildup. Hybrid safety system with active safety systems to terminate credible accidents and passive safety systems to terminate improbable, severe accidents.

References: Matsuoka, T., 1991. "A Simplified Japanese PWR," Nucl. Eng. Int., 36(443):47. 


\section{PRODUCT DATA SHEET}

\section{GENERAL CHARACTERISTICS}

Product Name: PIUS

Reactor Type: PWR

Electrical Power: $640 \mathrm{MW}(\mathrm{e})$

Design Type: PRIME

Developmental Status: Design

Availability: 1998

Vendor organization:

Utilities using product:

- ABB Atom

-

-

$\bullet$

\section{TECHNICAL CHARACTERISTICS}

\section{Reactor:}

Thermal power: $2000 \mathrm{MW}(\mathrm{t})$

Electrical power: $640 \mathrm{MW}(\mathrm{e})$

Coolant inlet temp: $260^{\circ} \mathrm{C}$

Coolant outlet temp: $290^{\circ} \mathrm{C}$

\section{Fuel Design:}

Fuel composition: $\mathrm{UO}_{2}$

Fuel enrichment:

Array size: $18 \times 18$

No. of fuel assemblies: 213

Core loading (MTU):

Av fuel burnup:

Power density: $72.3 \mathrm{~kW} / \mathrm{L}$

Operating cycle: $11-12$ months

\section{Steam Generator Design:}

SG type:

No. of SGs: 4

\section{Safety System Design:}

Containments:

ECCS design:

List of unique safety systems:

Scheduling:

Construction time:

Construction cost:

Plant design life:

Comments: Zircaloy-4 cladding.

References: Nuclear News, "The New Reactors," Vol. 35, 12, pg. 65-90, September 1992. 


\section{PRODUCT DATA SHEET}

\section{GENERAL CHARACTERISTICS}

Product Name: Safe Integral Reactor

Reactor Type: PWR

Electrical Power: $320 \mathrm{MW}(\mathrm{e})$

Design Type: Evolutionary Technology

Developmental Status: Design

Availability: TBD

Vendor oreanization:

- ABB-CE, U.S.A

- Stone \& Webster

- Rolls Royce \& Associates, Ltd.,

- U.K. Atomic Energy Authority

\section{TECHNICAL CHARACTERISTICS}

\section{Reactor:}

Thermal power: $1000 \mathrm{MW}(\mathrm{t})$

Electrical power: $320 \mathrm{MW}(\mathrm{e})$

Coolant inlet temp: $295^{\circ} \mathrm{C}$

Coolant outlet temp: $318^{\circ} \mathrm{C}$

\section{Utilities using product:}

\section{Steam Generator Design:}

SG type: modular once-through

No. of SGs: 12

\section{Safety System Design:}

Containments:

\section{Fuel Design:}

Fuel composition: $\mathrm{UO}_{2}$

Fuel enrichment: $3.3-4.0 \%$

Array size:

No. of fuel assemblies:

Core loading (MTU):

Av fuel burnup:

Power density: $55 \mathrm{~kW} / \mathrm{L}$

Operating cycle:

ECCS design: gravity- and steam-driven coolant injection

List of unique safety systems: passive pressurizer system using fluidic diodes, ADS, natural circulation condensers for RHR

Scheduling:

Construction time:

Construction cost:

Plant design life:

Comments: The entire primary nuclear system (core, steam generators, pressurizer, etc.) is located within a very large pressure vessel that provides a large water inventory similar to PRIME reactor concepts. The developmental program is currently on hold.

References: NEA, 1991. Small and Medium Nuclear Reactors, Organization for Economic Cooperation and Development/Nuclear Energy Agency.

Andrews, P.J., Hall, S. F., and Gibson, I. H., 1991. "SIR Reactor Safety and Decommissioning," Journal of the British Nuclear Energy Society. 


\section{PRODUCT DATA SHEET}

\section{GENERAL CHARACTERISTICS}

Product Name: Simplified Boiling-Water Reactor

Reactor Type: BWR

Electrical Power: $640 \mathrm{MW}(\mathrm{e})$

Design Type: Evolutionary Technology

Developmental Status: Design

Availability: U. S. NRC design certification in January 1995

Vendor organization:

- General Electric, U.S.A.

- Hitachi Ltd., Japan

- Toshiba Co., Japan

-

\section{TECHNICAL CHARACTERISTICS}

Reactor:

Thermal power: $2000 \mathrm{MW}(\mathrm{t})$

Electrical power: $640 \mathrm{MW}(\mathrm{e})$

Coolant inlet temp: $216^{\circ} \mathrm{C}$

Coolant outlet temp: $288^{\circ} \mathrm{C}$

\section{Fuel Design:}

Fuel composition: $\mathrm{UO}_{2}$

Fuel enrichment:

Array size: $8 \times 8$ or $9 \times 9$

No. of fuel assemblies: 732

Core loading (MTU):

Av fuel burnup:

Power density: $41.0 \mathrm{~kW} / \mathrm{L}$

Operating cycle: 24 months
Utilities using product:

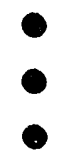

\section{Steam Generator Design:}

SG type: N/A

No. of SGs: N/A

Safety System Design:

Containments: steel primary with reinforced concrete secondary

ECCS design: gravity-driven, low-pressure coolant injection

List of unique safety systems: suppression pool, PCCS, isolation condenser to remove decay heat, ADS

\section{Scheduling:}

Construction time:

Construction cost:

Plant design life:

Comments: Uses a hybrid safety system. The PCCS consists of a "water wall" that removes decay heat from the PV using natural circulation water flow similar to the Toshiba 900 Seawater Coolant System. Zircaloy-2 cladding.

References: GE Advanced Boiling Water Reactors, D. R. Wilkins, GE Nuclear Energy, April 1990.

The Energy Daily, pg. 3, April 23, 1992.

Nuclear News, "The New Reactors," Vol 35, 12, pg. 65-90, September 1992. 


\section{PRODUCT DATA SHEET}

\section{GENERAL CHAKACTERISTICS}

Product Name: Tusniba 900

Reactor Type: BWR

Electrical Power: 310 MV(e)

Design Type: Evoluti nary Technology

Developmental Status: Design

Availability: TBD

Vendor organization:

- Toshiba Cciporation, Japan

-

\section{TECHNICAL CHARACTERISTICS}

Reactor:

Thermal power: $900 \mathrm{MW}(\mathrm{t})$

Electrical power: $310 \mathrm{MW}(\mathrm{e})$

Coolant inlet temp:

Coolant outlet temp:

\section{Fuel Design:}

Fuel composition:

Fuel enrichment:

Array sire: $8 \times 8$

No. of fuel assemblies: 388

Core loading (MTJ):

Av fuel burnuf:

Power density $40 \mathrm{~kW} / \mathrm{L}$

Operating cycle:

\section{Utilities using product:}

\section{Sieam Generator Design:}

SG type: large, external steam drums

No. of SGs: 2 steam drums

Safety System Design:

Containments: steel primary with reinforced concrete secondary ECCS design: high and low pressure accumulators, gravity-driven coolani injection List of unique safety systems: ADS, PCS, PCCS

\section{Scheduliug:}

Construction time:

Construction cost:

Plant design life:

Comments: i To steam separators or dryers in the reactor pressure vessel (to enhance natural water circulation). Top-mounted, gravity-driven, control-rod drive mechanism. Natural circulation seawater coolant system.

References: Oka, Yoshiaki, 1989. "Research and Development of Next Generation Light Water Reactors in Japan," International Atomic Energy Agency Technical Committee Meeting on Passive Safety Features in Current and Future Water-Cooled Reactors, Moscow, USSR, March 21-24, 1989. 


\section{PRODUCT DATA SHEET}

\section{GENERAL CHARACTERISTICS}

Product Name: VVER 88/91/92

Reactor Type: PWR

Electrical Power: $1000 \mathrm{MW}(\mathrm{e})$

Design Type: Evolutionary Plant

Developmental Status: Design

Availability: Late 1990s for VVER 92, earlier for other designs

\section{Vendor organization:}

- MTM

\section{TECHNICAL CHARACTERISTICS}

\section{Reactor:}

Thermal power: $3000 \mathrm{MW}(\mathrm{t})$

Electrical power: $1000 \mathrm{MW}(\mathrm{e})$

Coolant inlet temp: $290^{\circ} \mathrm{C}$

Coolant outlet temp: $320^{\circ} \mathrm{C}$

\section{Fuel Design:}

Fuel composition: $\mathrm{UO}_{2}$

Fuel enrichment: $2 \%, 3 \%, 4.4 \%$

Array size:

No. of fuel assemblies: 163

Core loading (MTU): 80.1

Av fuel burnup: $42 \mathrm{GWd} / \mathrm{MT}$

Power density: $12.9 \mathrm{~kW} / \mathrm{m}$

Operating cycle: 3 years
Utilities using product:

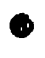

Steam Generator Design:

SG type: horizontal design

No. of SGs: 4

\section{Safety System Design:}

Containments: dual steel-lined concrete ECCS design: passive injection system

List of unique safety systems: PRHR, PCCS

Scheduling:

Construction time:

Construction cost:

Plant design life:

Comments: VVER-88 (also V-392) is basically a VVER-1000 with added passive heat removal systems and containment venting. VVER 91 is being developed for Finland. VVER-92 (also V-410) is further refined to simplify design and improve economics. Other advanced VVER concepts are being developed.

References: Nuclear News, Vol. 35, 14, pg. 57, November 1992.

Nuclear Engineering International, Vol. 36, 440, pg. 17-33, March 1991. 


\title{
PRODUCT DATA SIEET
}

\section{GENERAL CHARACTERISTICS}

Product Name: Advanced CANDU Reactor

Reactor Type: HWR

Electrical Power: $900 \mathrm{MW}(\mathrm{e})$

Design Type: PRIME

Developmental Status: Research

Availability: TBD

Vendor organization:

- AECL, Canada

-

-

\section{TECHNICAL CHARACTERISTICS}

\section{Reactor:}

Thermal power:

Electrical power: $900 \mathrm{MW}(\mathrm{e})$

Coolant inlet temp:

Coolant outlet temp:

\section{Fuel Design:}

Fuel composition: $\mathrm{UO}_{2}$

Fuel enrichment: natural

Array size:

No. of fuel assemblies:

Core loading (MTU):

Av fuel burnup:

Power density:

Operating cycle: continuous, on-

line refueling

\section{Utilities using product:}

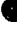

-

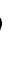

\author{
Steam Generator Design: \\ SG type: \\ No. of SGs: \\ Safety System Design: \\ Containments: reinforced concrete \\ ECCS design: calandria with heat pipe \\ List of unique safety systems: PCCS, PRHR \\ Scheduling: \\ Construction time: \\ Construction cost: \\ Plant design life:
}

Comments: AECL has begun research and development at the Chalk River Laboratory. The insulated pressure tubes become highly conductive at elevated temperatures to provide passive core cooling.

References: Forsberg, C. W., Reich, W. J., "Worldwide Advanced Nuclear Power Reactors with Passive and Inherent Safety: What, Why, How, and Who," ORNL/TM11907, Oak Ridge National Laboratory, September 1991. 


\section{PRODUCT DATA SHEET}

\section{GENERAL CHARACTERISTICS}

Product Name: ALMR

Reactor Type: LMFBR

Electrical Power: $1440 \mathrm{MW}(\mathrm{e})$

Design Type: Breeder

Developmental Status: Design

Availability: Design certification targeted for 2005

\section{Vendor organization:}

- General Electric, U.S.A.

\section{TECHNICAL CHARACTERISTICS}

\section{Reactor:}

Thermal power: $4245 \mathrm{MW}(\mathrm{t})$

Electrical power: $1440 \mathrm{MW}(\mathrm{e})$

Coolant inlet temp: $338^{\circ} \mathrm{C}$

Coolant outlet temp: $485^{\circ} \mathrm{C}$

\section{Fuel Design:}

Fuel composition: U-Pu-Zr metal Fuel enrichment:

Array size: 217 pins in hex bundle No. of fuel assemblies: 66

Core loading (MTU):

Av fuel burnup:

Power density: $180 \mathrm{~kW} / \mathrm{L}$ avg.

Operating cycle: 24 months

\section{Utilities using product:}

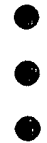

\section{Steam Generator Design:}

SG type: N/A

No. of SGs: N/A

\section{Safety System Design:}

Containments:

ECCS design:

List of unique safety systems:

\section{Scheduling:}

Construction time:

Construction cost:

Plant design life:

Comments: The U.S. DOE program to develop an Advanced Liquid Metal Reactor (ALMR) involves applying Argonne National Laboratory's Integral Fast Reactor concept to GE's PRISM (Power Reactor Innovative Small Module) breeder reactor design. Liquid sodium coolant. HT-9 ferritic alloy cladding.

References: Nuclear News, "The New Reactors," Vol. 35, 12, pg. 65-90, September 1992. 


\section{PRODUCT DATA SHEET}

\section{GENERAL CHARACTERISTICS}

Product Name: European Fast Reactor

Reactor Type: LMFBR

Electrical Power: $1450 \mathrm{MW}(\mathrm{e})$

Design Type: Breeder

Developmental Status: Design

Availability: Basic design completed in 1998

Vendor organization:

EFR Associates

\section{TECHNICAL CHARACTERISTICS}

Reactor:

Thermal power: $3600 \mathrm{MW}(\mathrm{t})$

Electrical power: $1450 \mathrm{MW}(\mathrm{e})$

Coolant inlet temp: $395^{\circ} \mathrm{C}$

Coolant outlet temp: $545^{\circ} \mathrm{C}$

\section{Fuel Design:}

Fuel composition: Mixed $\mathrm{UO}_{2}$ and

Fuel enrichment:

$$
\mathrm{PuO}_{2}
$$

Array size: 331 pins in triangle

No. of fuel assemblies: 387

Core loading (MTU):

Av fuel burnup:

Power density: $290 \mathrm{~kW} / \mathrm{L}$

Operating cycle: 12 months
Utilities using product:

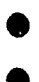

\author{
Steam Generator Design: \\ SG type: N/A \\ No. of SGs: N/A \\ Safety System Design: \\ Containments: \\ ECCS design: \\ List of unique safety systems:
}

\section{Scheduling:}

Construction time:

Construction cost:

Plant design life:

Comments: European Fast Reactor (EFR) Associates is a joint design organization made up of Novatome, a division of Framatome of France; Siemens KWU of German; and NNC, Ltd., of Great Britain. Austenitic stainless steel cladding.

References: Nuclear News, "The New Reactors," Vol. 35, 12, pg. 65-90, September 1992. 


\section{PRODUCT DATA SHEET}

\section{GENERAL CHARACTERISTICS}

Product Name: MHTGK/Gas Turbine

Reactor Type: HTGR

Electrical Power: $100 \mathrm{MW}(\mathrm{e})$

Design Type: PRIME

Developmental Status: Research

Availability: TBD

Vendor organization:

MIT, USA

\section{TECHNICAL CHARACTERISTICS}

\section{Reactor:}

Thermal power: $350 \mathrm{MW}(\mathrm{t})$

Electrical power: $100 \mathrm{MW}(\mathrm{e})$

Coolant inlet temp: $576^{\circ} \mathrm{C}$

Coolant outlet temp: $850^{\circ} \mathrm{C}$

\section{Fuel Design:}

Fuel composition: $\mathrm{UCO}, \mathrm{THO}_{2}$

Fuel enrichment:

Array size:

No. of fuel assemblies:

Core loading (MTU):

Av fuel burnup:

Power density: $5.9 \mathrm{~kW} / \mathrm{L}$

Operating cycle:

\section{Utilities using product:}

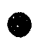

\section{Steam Generator Design:}

SG type: N/A

No. of SGs: N/A

\section{Safety System Design:}

Containments:

ECCS design:

List of unique safety systems:

Scheduling:

Construction time:

Construction cost:

Plant design life:

Comments: This direct cycle MHTGR developed at MIT uses helium as both the reactor coolant and the working fluid to drive a gas turbine to produce electric power. the design is modular with data shown for one modular reactor unit.

References: Proceedings of the International Workshop on the Closed-Cycle Gas-Turbine Modular High-Temperature Gas-Cooled Reactor, Gas-Cooled Reactor Associates, Massachusetts Institute of Technology (MIT), June 17-19, 1991. 


\section{PRODUCT DATA SHEET}

\section{GENERAL CHARACTERISTICS}

Product Name: MHTGR/U.S.

Reactor Type: HTGR

Electrical Power: 538 MW(e)

Design Type: PRIME

Developmental Status: Design

Availability: Estimated final design in 2001

Vendor organization:

- General Atomics, U.S.A.

\section{-}

\section{TECHINICAL CHARACTERISTICS}

Reactor:

Thermal power: $1400 \mathrm{MW}(\mathrm{t})$

Electrical power: $538 \mathrm{MW}(\mathrm{e})$

Coolant inlet temp: $258^{\circ} \mathrm{C}$

Coolant outlet temp: $687^{\circ} \mathrm{C}$

\section{Fuel Design:}

Fuel composition: $\mathrm{UCO}, \mathrm{THO}_{2}$

Fuel enrichment: $19.9 \%$

Array size: Hexagonal graphite blocks

No. of fuel assemblies: 660

Core loading (MTU):

Av fuel burnup:

Power density: $5.9 \mathrm{~kW} / \mathrm{L}$

Operating cycle: 19 months
Utilities using product:

?

Steam Generator Design:

SG type: N/A

No. of SGs: N/A

Safety System Design:

Containments:

ECCS design:

List of unique safety systems:

Scheduling:

Construction time:

Construction cost:

Plant design life: 40 years

Comments: Helium coolant and graphite moderator. Refractory coating on fuel particles serves as cladding. The technical characteristics are shown for four combined reactor modules. There will be four modules, $350 \mathrm{MW}(\mathrm{t})$ each, per nuclear power plant.

References: Nuclear News, "The New Reactors," Vol. 35, 12, pg. 65-90, September 1990. 


\section{PRODUCT DATA SHEET}

\section{GENERAL CHARACTERISTICS}

Product Name: System Integrated Pressurized-Water Reactor

Reactor Type: PWR

Electrical Power: $350 \mathrm{MW}(\mathrm{e})$

Design Type: Evolutionary Technology

Developmental Status: Design

Availability: TBD

Vendor organization:

JAERI

\section{-}

-

\section{TECHNICAL CHARACTERISTICS}

Reactor:

Thermal power: $1100 \mathrm{MW}(\mathrm{t})$

Electrical power: $350 \mathrm{MW}(\mathrm{e})$

Coolant inlet temp: $280^{\circ} \mathrm{C}$

Coolant outlet temp: $310^{\circ} \mathrm{C}$

Fuel Design:

Fuel composition: $\mathrm{UO}_{2}$

Fuel enrichment:

Array size:

No. of fuel assemblies:

Core loading (MTU):

Av fuel burnup:

Power density: $84 \mathrm{MW}(\mathrm{t}) / \mathrm{m}^{3}$

Operating cycle:
Utilities using product:

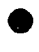

.

\section{Steam Generator Design:}

SG type: once-through, helical coil

No. of SGs: 4

\section{Safety System Design:}

Containments:

ECCS design: natural circulation boron injection

List of unique safety systems: passive, hydraulic valves for boron tank

\section{Scheduling:}

Construction time:

Construction cost:

Plant design life:

Comments: Fully-integrated primary cooling system within the RPV and no openings or pipes below the core. Designed by Japan Atomic Energy Research Institute (JAERI). This is an advanced reactor concept still in the early design stages.

References: NEA, 1991. Small and Medium Nuclear Reactors, Organization for Economic Cooperation and Development/Nuclear Energy Agency. 
Appendix C. CUSTOMER BASE FOR NUCLEAR POWER PLANTS 


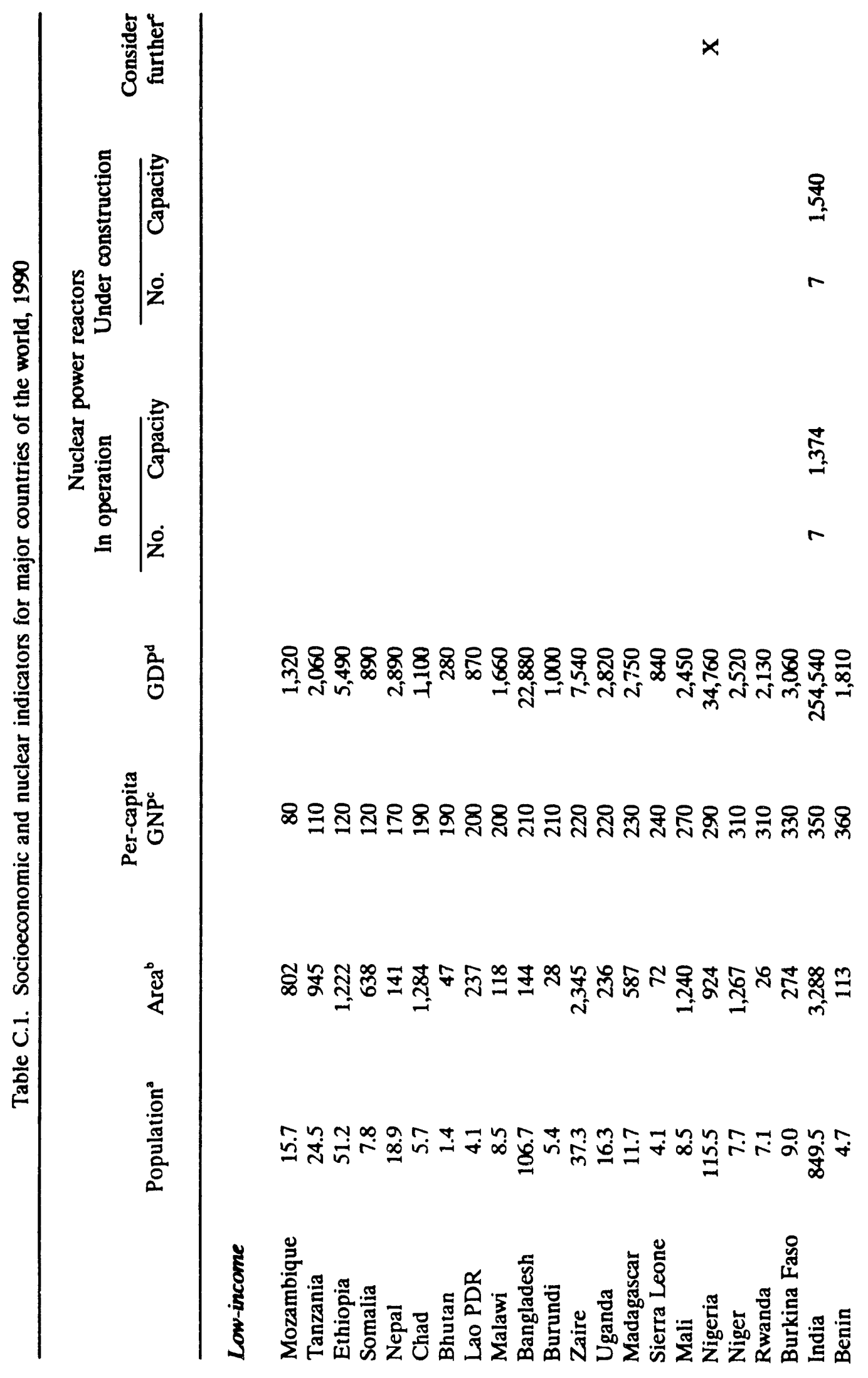




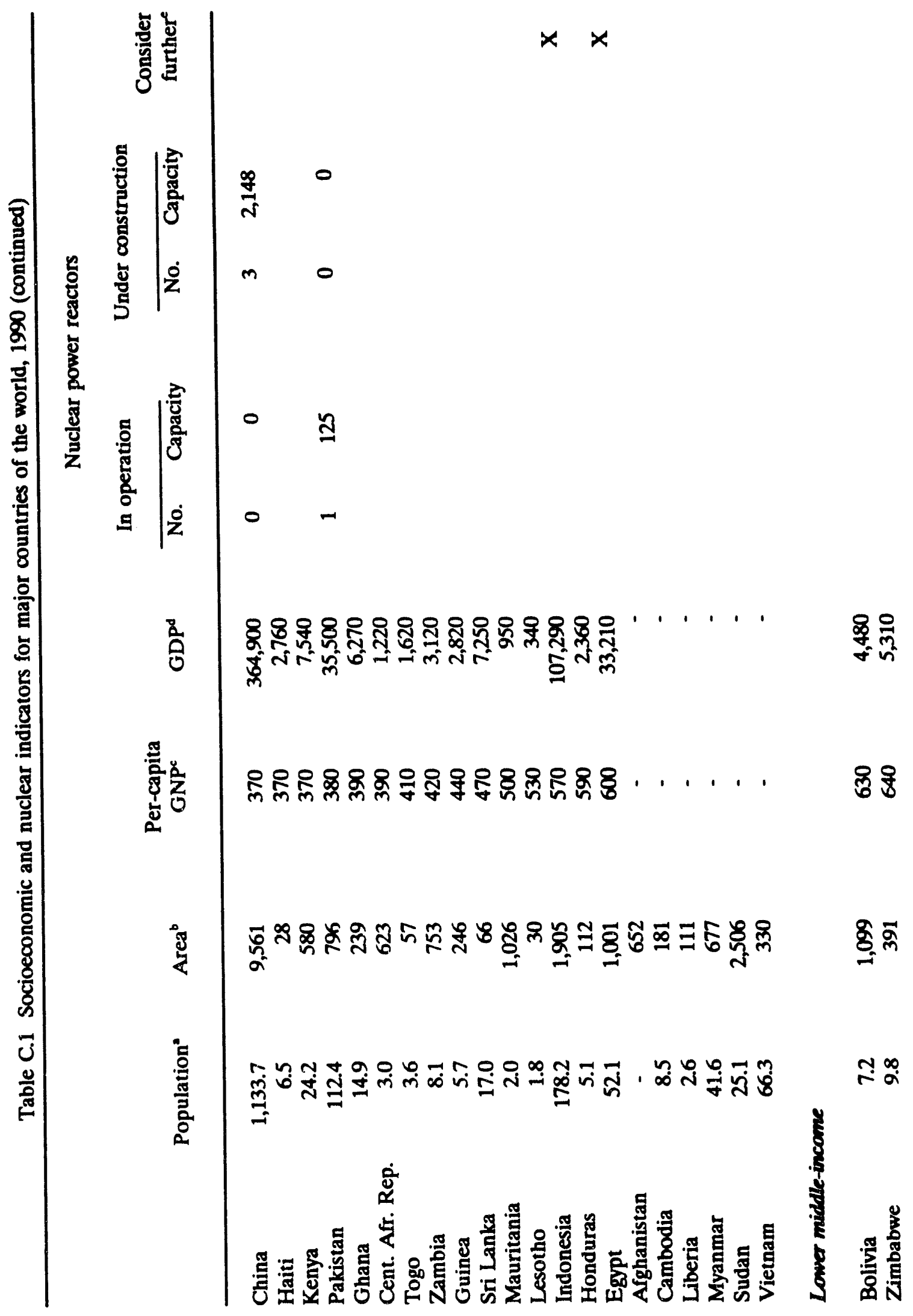




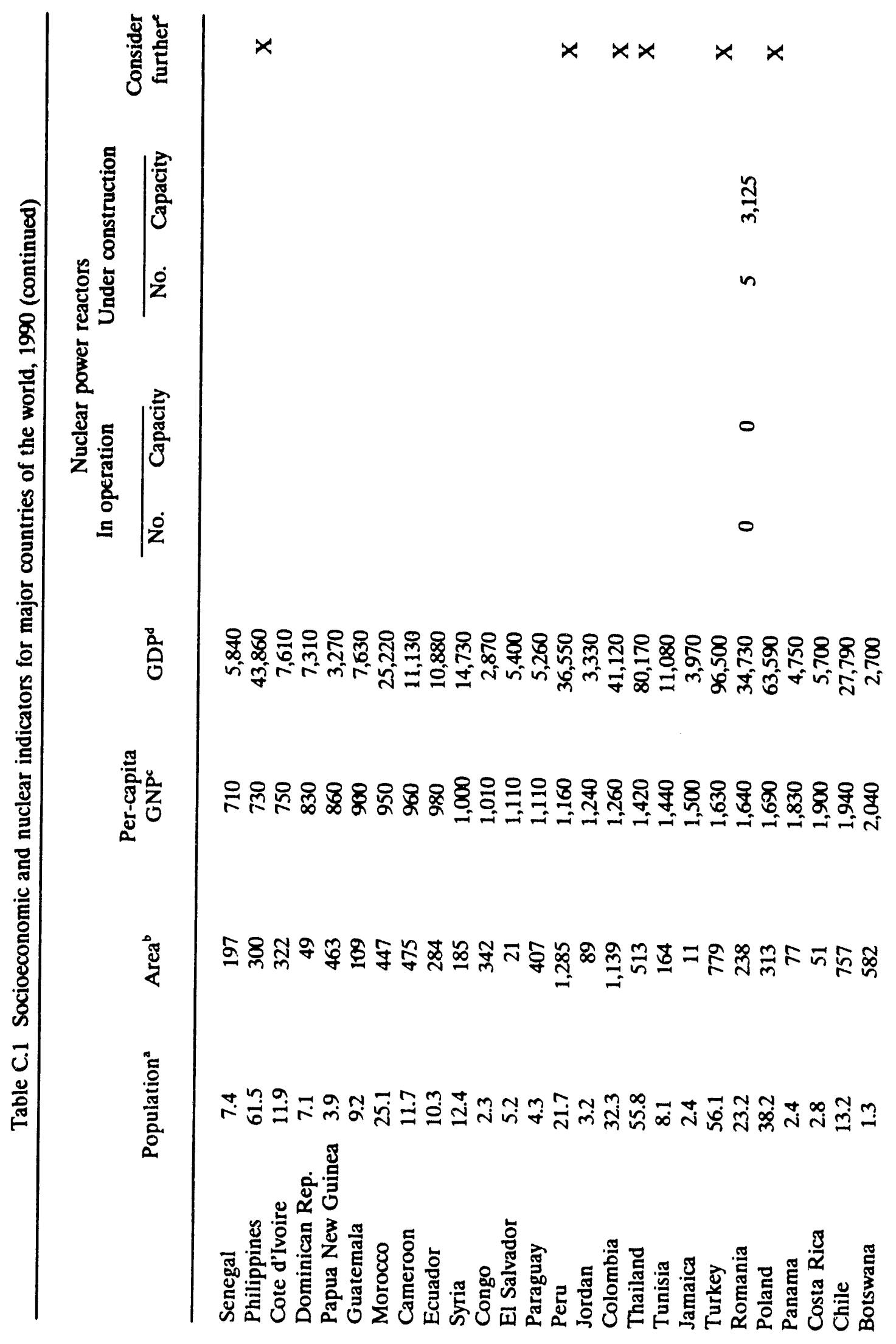




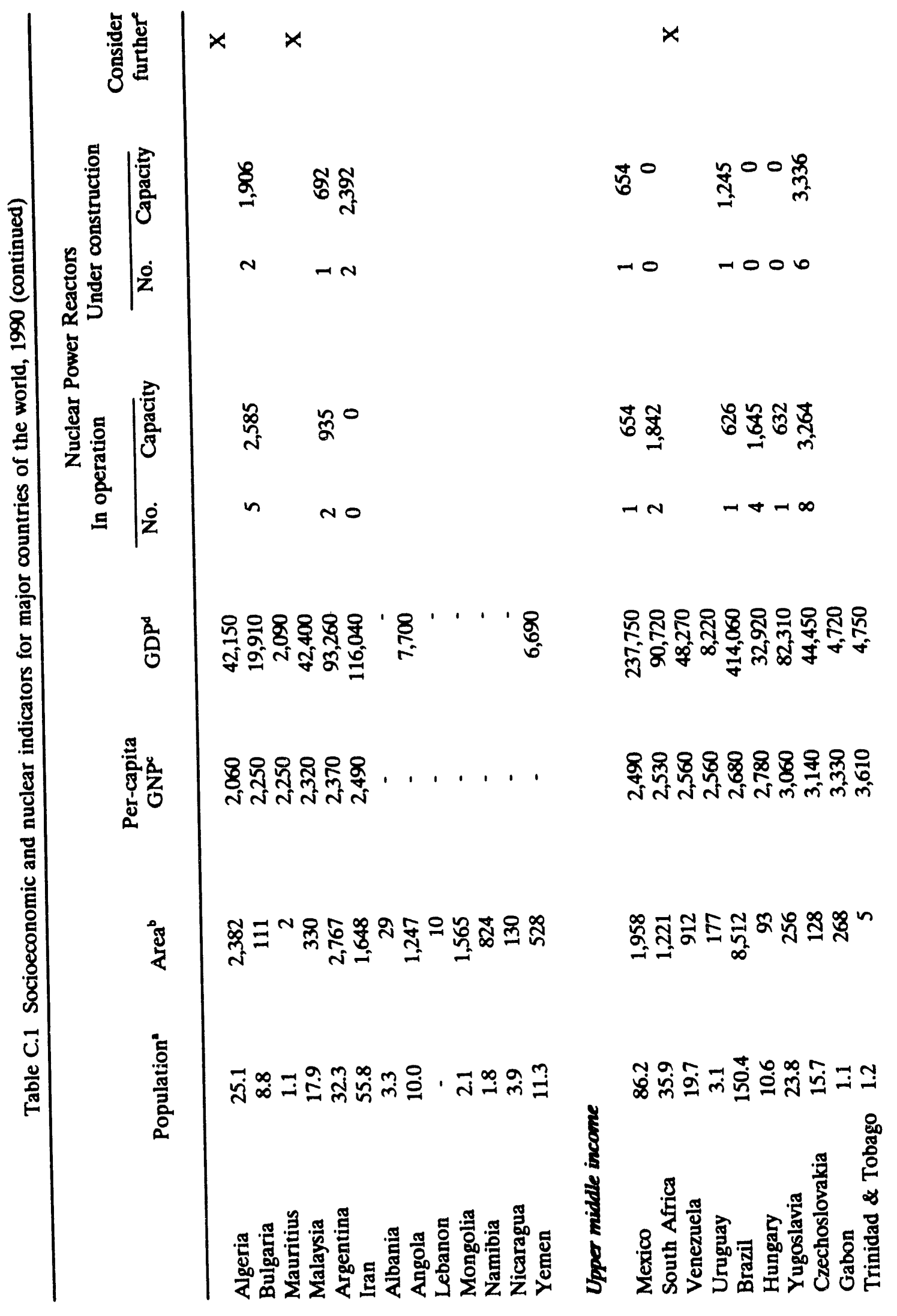




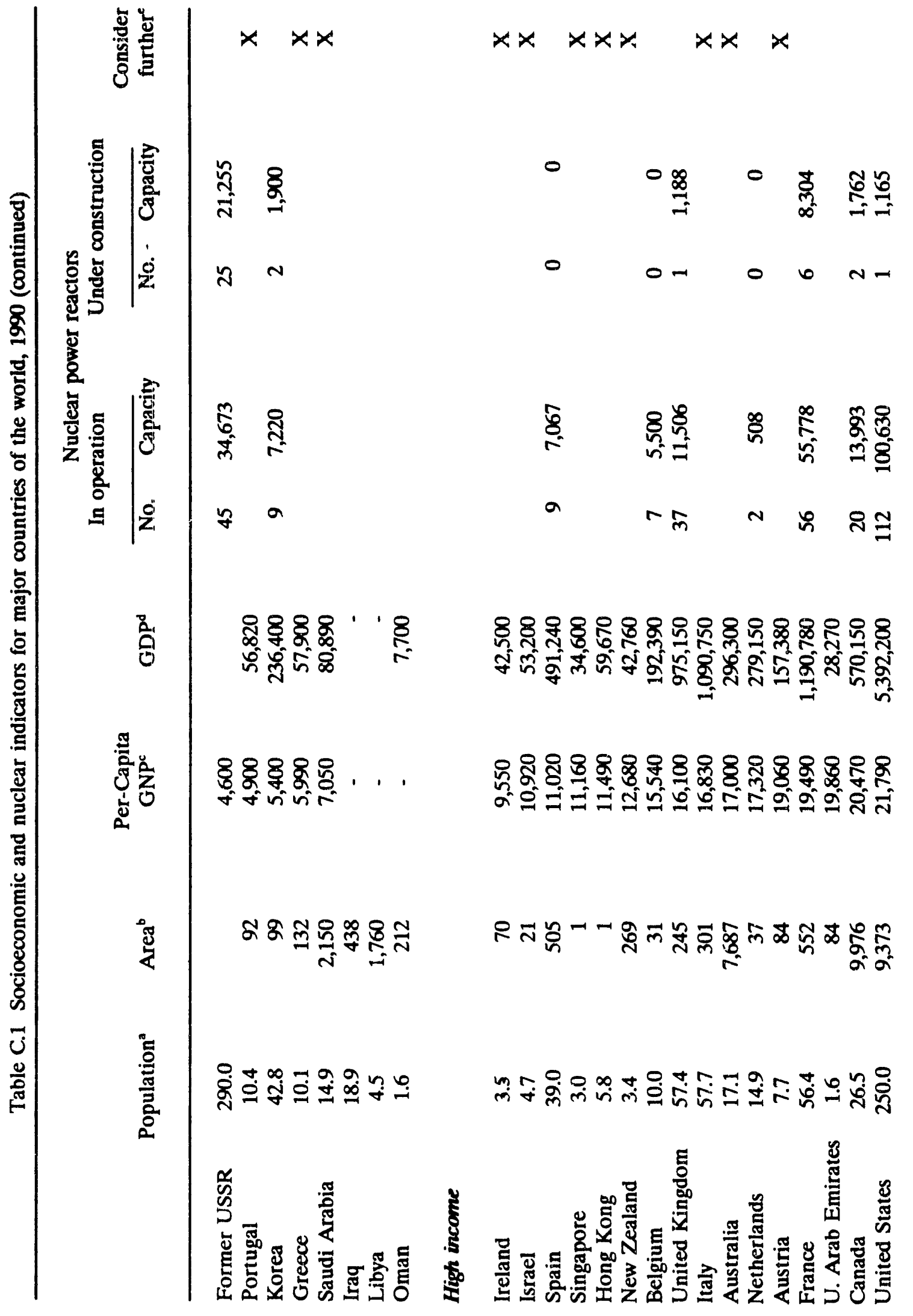




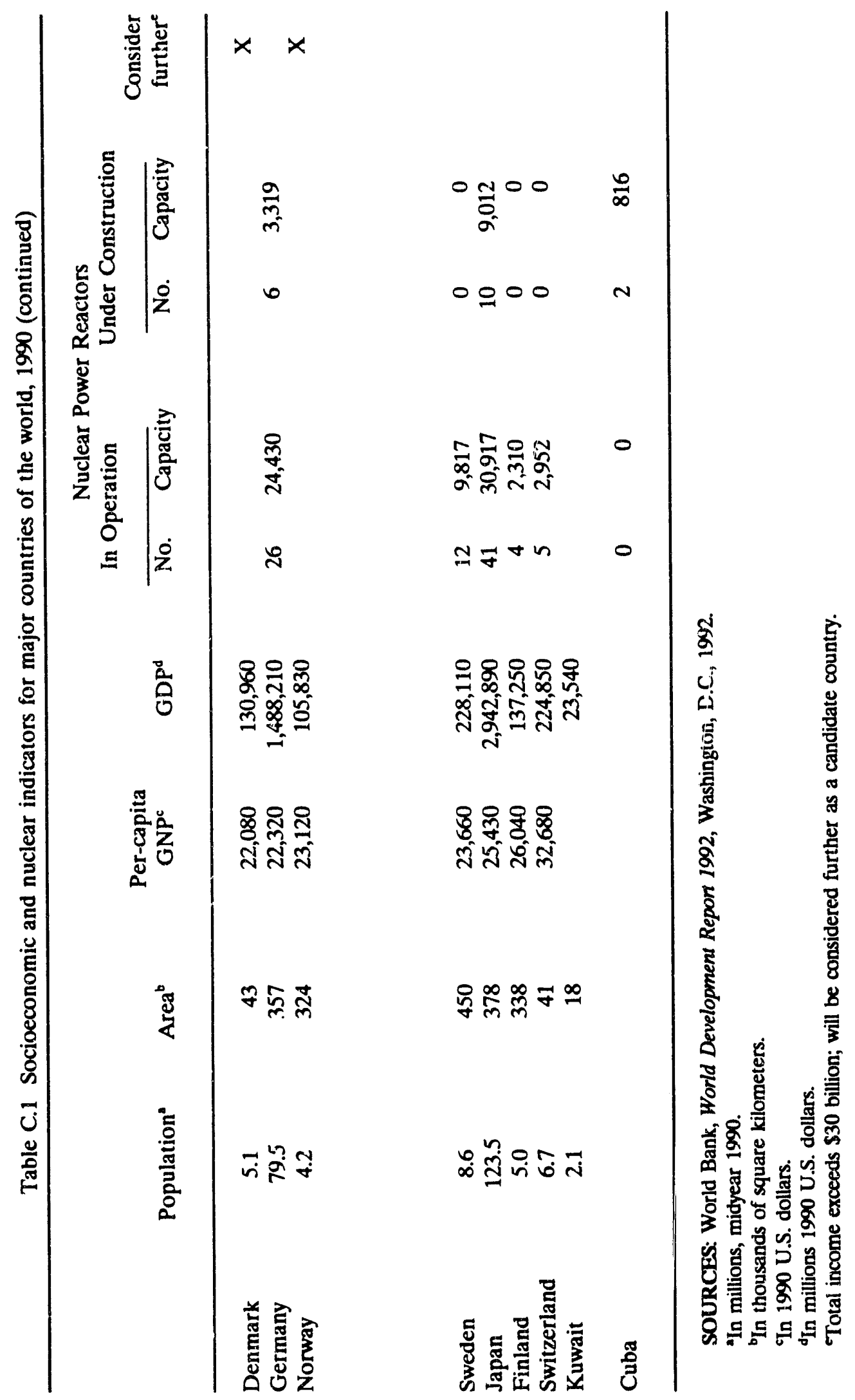


Table C.2. Electricity generation by fuel type, candidate countries, 1989

\begin{tabular}{|c|c|c|c|c|c|}
\hline & \multicolumn{4}{|c|}{$\%$ composition } & \multirow{2}{*}{$\begin{array}{c}\text { Total } \\
\text { generation } \\
(\mathrm{tWh})\end{array}$} \\
\hline & Thermal $^{b}$ & Hydro & Nuclear & Other ${ }^{e}$ & \\
\hline \multicolumn{6}{|l|}{ Low income } \\
\hline Egypt & 81.9 & 18.1 & 0.0 & 0.0 & 35.3 \\
\hline Indonesia & 83.6 & 15.6 & 0.0 & 0.7 & 27.5 \\
\hline Nigeria & 76.8 & 22.2 & 0.0 & 0.0 & 9.9 \\
\hline \multicolumn{6}{|c|}{ Lower-middle income } \\
\hline Algeria & 98.6 & 1.4 & 0.0 & 0.0 & 14.5 \\
\hline Colombia & 18.5 & 81.5 & 0.0 & 0.0 & 36.2 \\
\hline Malaysia & 70.0 & 30.0 & 0.0 & 0.0 & 20.7 \\
\hline Peru & 9.4 & 90.6 & 0.0 & 0.0 & 9.6 \\
\hline Philippines & 52.8 & 26.0 & 0.0 & 21.2 & 25.0 \\
\hline Poland & 97.2 & 2.8 & 0.0 & 0.0 & 136.9 \\
\hline Thailand & 85.0 & 15.0 & 0.0 & 0.0 & 37.4 \\
\hline Turkey & 63.1 & 36.7 & 0.0 & 0.2 & 48.8 \\
\hline \multicolumn{6}{|c|}{ Upper-middle income } \\
\hline Greece & 93.5 & 6.5 & 0.0 & 0.0 & 33.7 \\
\hline Portugal & 76.1 & 23.9 & 0.0 & - & 24.3 \\
\hline Saudi Arabia & 100.0 & 0.0 & 0.0 & 0.0 & 45.0 \\
\hline Venezuela & 37.8 & 62.2 & 0.0 & 0.0 & 55.0 \\
\hline \multicolumn{6}{|l|}{ High income } \\
\hline Australia & 88.9 & 10.5 & 0.0 & 0.6 & 137.4 \\
\hline Austria & 22.4 & 77.6 & 0.0 & 0.0 & 43.3 \\
\hline Denmark & 99.5 & - & 0.0 & 0.5 & 22.0 \\
\hline Hong Kong & 100.0 & 0.0 & 0.0 & 0.0 & 27.4 \\
\hline Ireland & 92.6 & 7.4 & 0.0 & 0.0 & 13.6 \\
\hline Israel & 100.0 & 0.0 & 0.0 & 0.0 & 19.8 \\
\hline Italy & 82.8 & 15.5 & 0.0 & 1.8 & 181.2 \\
\hline New Zealand & 18.1 & 77.7 & 0.0 & 4.3 & 28.2 \\
\hline Norway & 0.2 & 99.8 & 0.0 & 0.0 & 105.1 \\
\hline Singapore & 100.0 & 0.0 & 0.0 & 0.0 & 14.0 \\
\hline
\end{tabular}

SOURCE: United Nations (1991).

$A^{\prime}-$ ' signifies that the amount was $<500$ million $\mathrm{kWh}$.

'Does not include the production of electricity for self-use (i.e., auto-producers).

'Electricity generated from oil, gas, and coal.

'Electricity generated from geothermal, solar, biomass, wind, and other renewable sources. 
Table C.3. Production of conventional thermal electricity, candidate countries, 1988

\begin{tabular}{|c|c|c|c|c|}
\hline & \multicolumn{3}{|c|}{$\%$ Composition } & \multirow{2}{*}{$\begin{array}{c}\text { Total } \\
\left(10^{3} \mathrm{TOE}\right)\end{array}$} \\
\hline & Coal & Oil & Gas & \\
\hline \multicolumn{5}{|l|}{ Low income } \\
\hline $\begin{array}{l}\text { Egypt } \\
\text { Indonesia } \\
\text { Nigeria }\end{array}$ & $\begin{array}{r}0.0 \\
25.7 \\
0.0\end{array}$ & $\begin{array}{l}64.4 \\
72.6 \\
13.5\end{array}$ & $\begin{array}{r}35.6 \\
1.7 \\
86.5\end{array}$ & $\begin{array}{l}7,834 \\
7,911 \\
2,601\end{array}$ \\
\hline \multicolumn{5}{|c|}{ Lower-middle income } \\
\hline $\begin{array}{l}\text { Algeria } \\
\text { Colombia } \\
\text { Malaysia } \\
\text { Peru } \\
\text { Philippines } \\
\text { Poland } \\
\text { Thailand } \\
\text { Turkey }\end{array}$ & $\begin{array}{r}0.0 \\
27.5 \\
1.9 \\
0.0 \\
21.3 \\
93.2 \\
25.3\end{array}$ & $\begin{array}{r}7.2 \\
2.2 \\
67.9 \\
91.8 \\
78.7 \\
3.9 \\
9.3\end{array}$ & $\begin{array}{r}92.8 \\
70.3 \\
30.2 \\
8.2 \\
0.0 \\
2.9 \\
65.3\end{array}$ & $\begin{array}{r}4,754 \\
2,139 \\
3,274 \\
765 \\
2,886 \\
50,466 \\
6,291\end{array}$ \\
\hline \multicolumn{5}{|c|}{ Upper-middle income } \\
\hline \multicolumn{5}{|l|}{ Greece } \\
\hline $\begin{array}{l}\text { Saudi Arabia } \\
\text { Venezuela }\end{array}$ & $\begin{array}{l}0.0 \\
0.0\end{array}$ & $\begin{array}{l}58.8 \\
24.0\end{array}$ & $\begin{array}{l}41.2 \\
76.0\end{array}$ & $\begin{array}{r}15,135 \\
4,928\end{array}$ \\
\hline \multicolumn{5}{|l|}{ High income } \\
\hline \multicolumn{5}{|l|}{$\begin{array}{l}\text { Australia } \\
\text { Austria } \\
\text { Denmark }\end{array}$} \\
\hline $\begin{array}{l}\text { Hong Kong } \\
\text { Ireland }\end{array}$ & 98.6 & 1.4 & 0.0 & 5,776 \\
\hline $\begin{array}{l}\text { Israel } \\
\text { Italy } \\
\text { New Zealand } \\
\text { Norway }\end{array}$ & 46.9 & 53.1 & 0.0 & 4,371 \\
\hline Singapore & 0.0 & 100.0 & 0.0 & 2,961 \\
\hline
\end{tabular}

SOURCE: International Energy Agency (1990). 


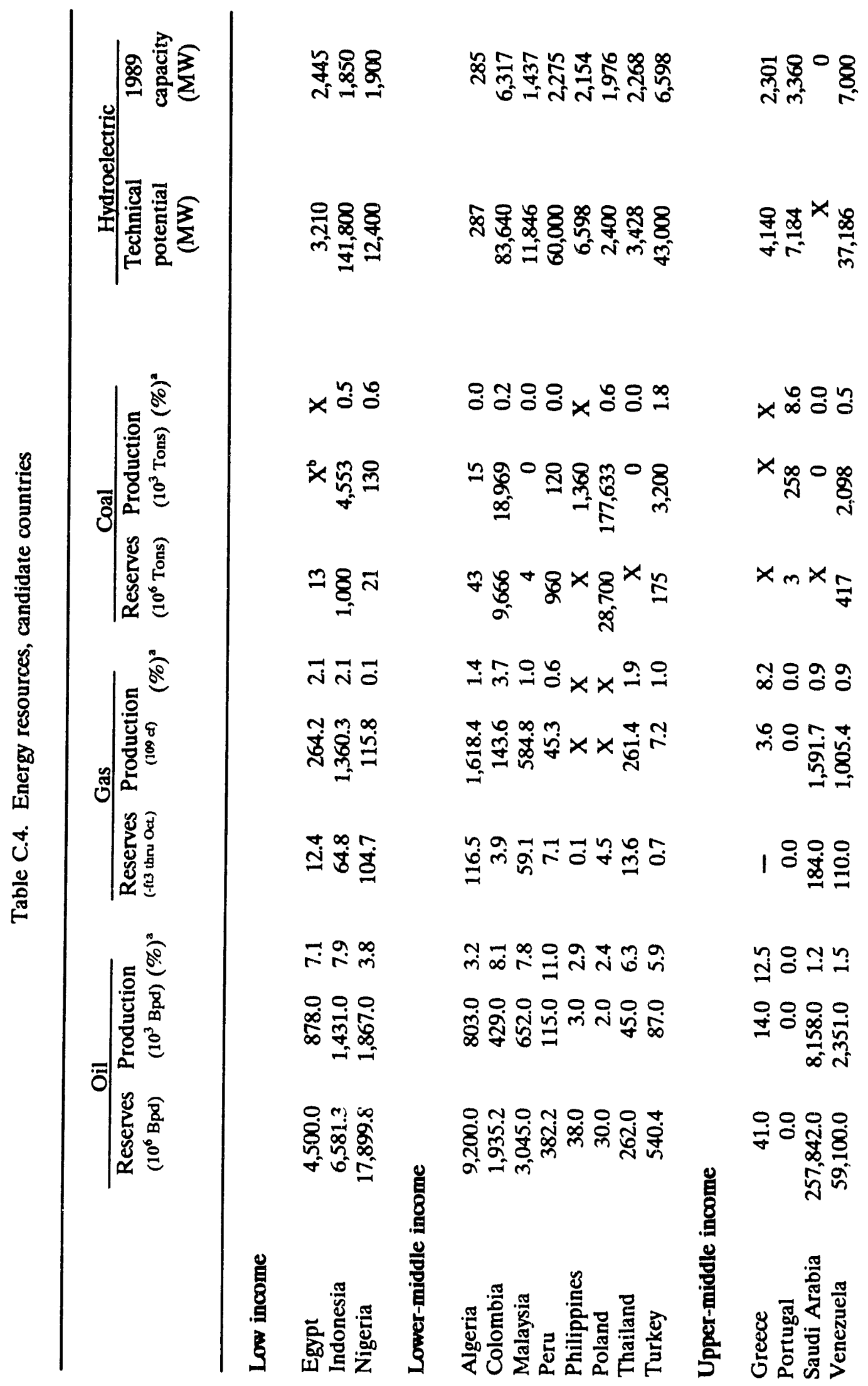




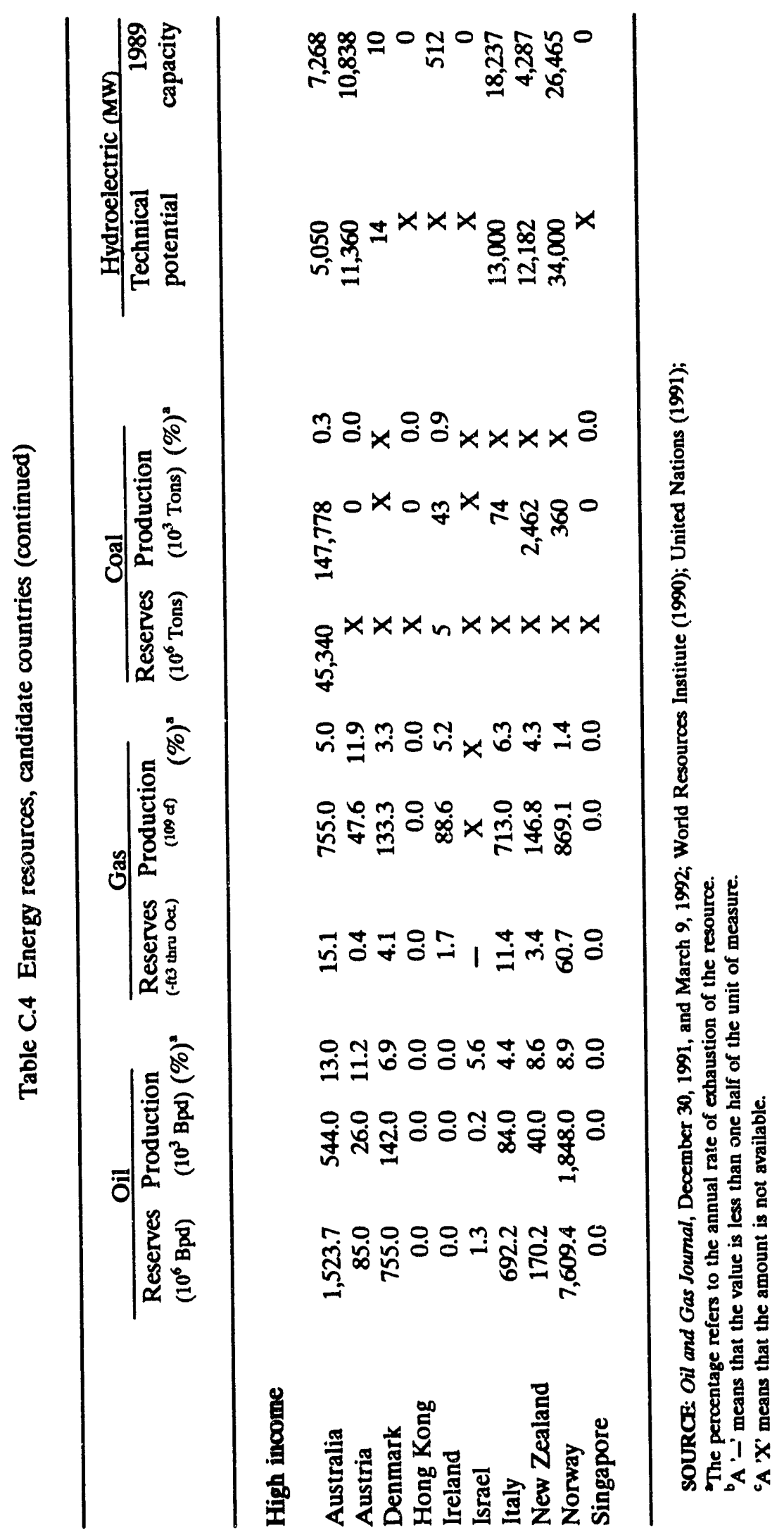




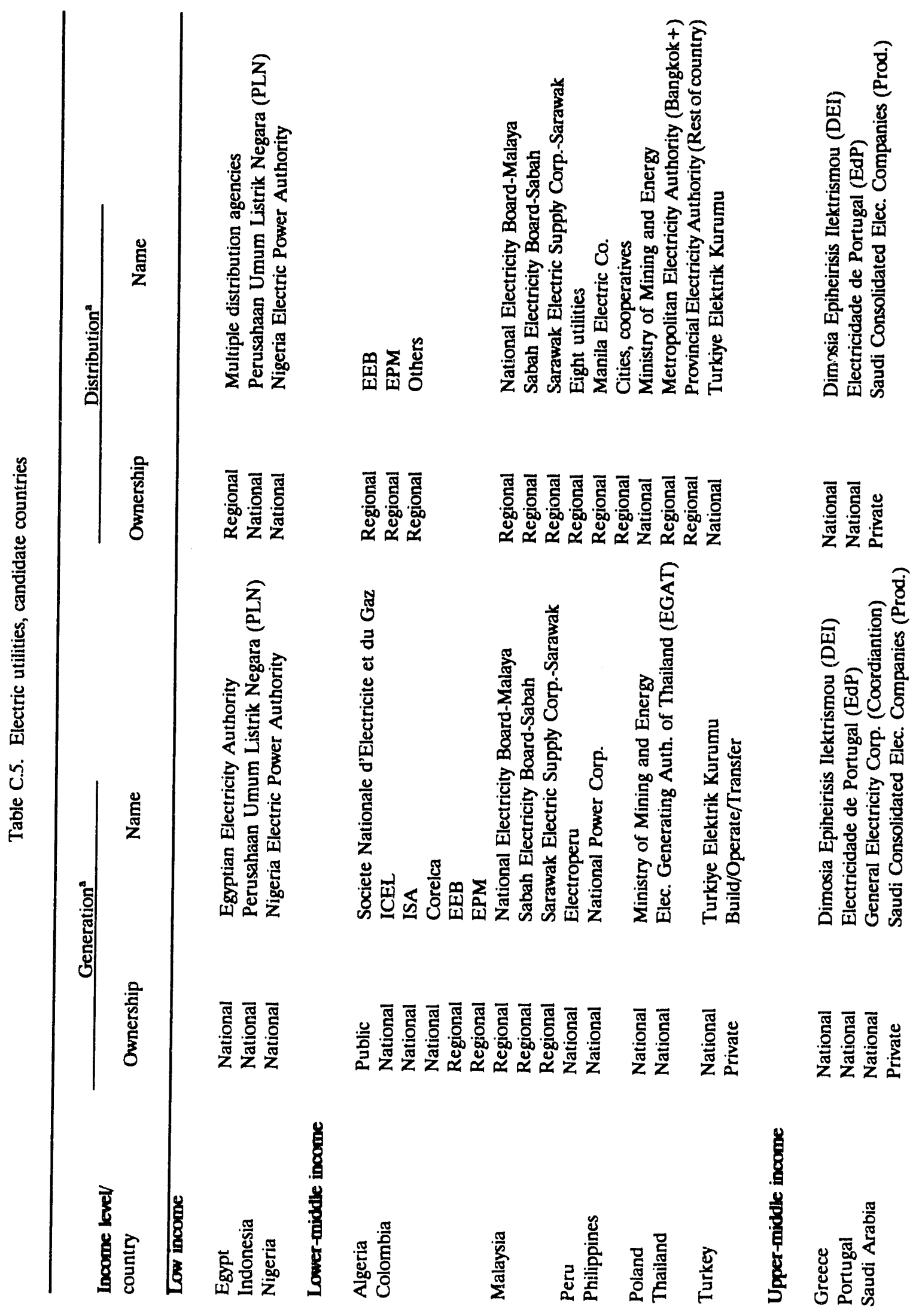




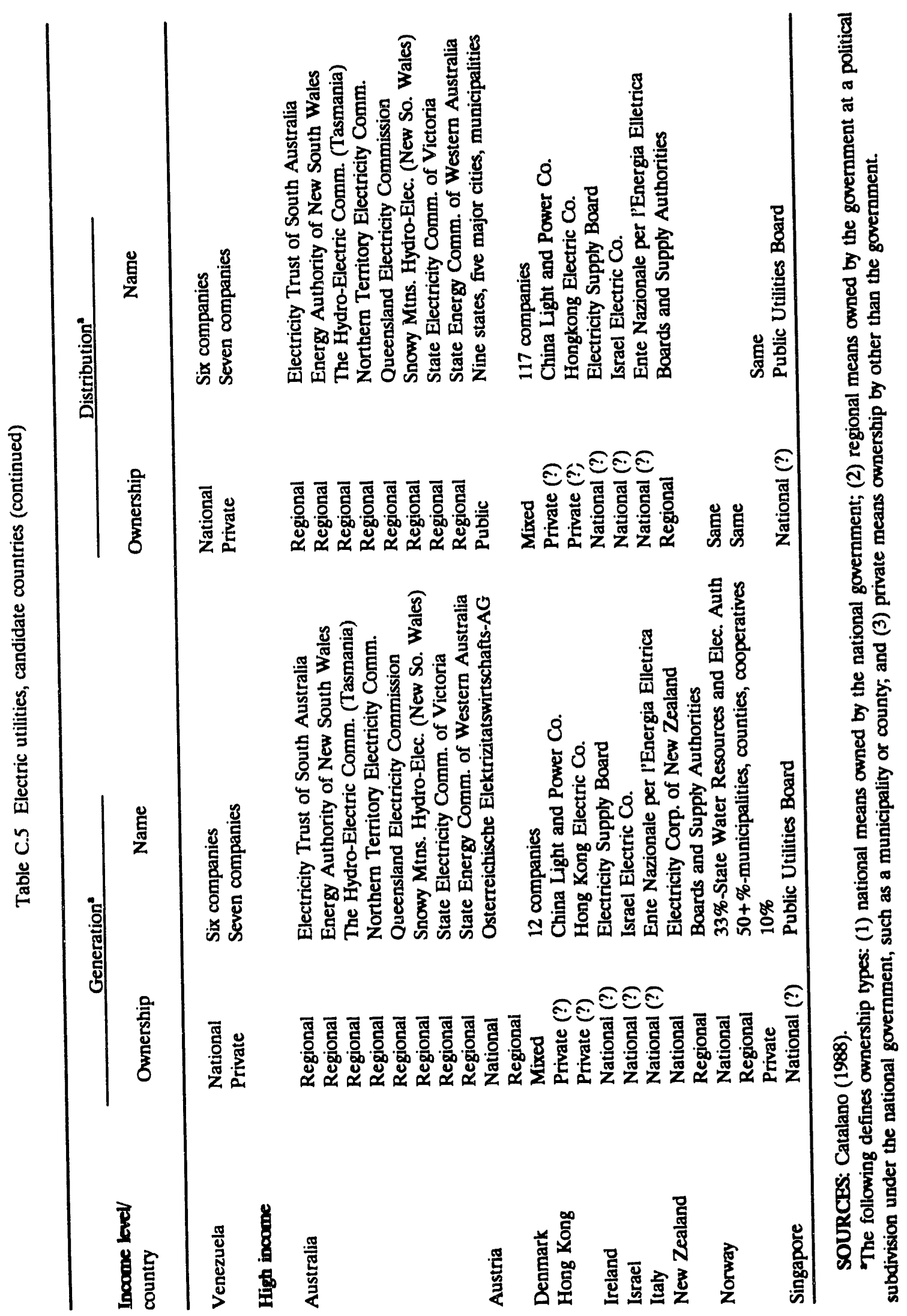


Table C.6. Electricity generation by fuel type," nuclear countries, 1989

\begin{tabular}{|c|c|c|c|c|c|}
\hline & \multicolumn{4}{|c|}{$\%$ Composition } & \multirow{2}{*}{$\begin{array}{c}\text { Total } \\
\text { generation } \\
(\mathrm{tWh})\end{array}$} \\
\hline & Thermal $^{b}$ & Hydro & Nuclear & Other $^{c}$ & \\
\hline \multicolumn{6}{|l|}{ Low income } \\
\hline China & 81.2 & 18.8 & 0.0 & 0.0 & 582.0 \\
\hline India & 71.0 & 26.0 & 3.0 & 0.0 & 245.2 \\
\hline Pakistan & 52.0 & 48.0 & - & 0.0 & 35.4 \\
\hline \multicolumn{6}{|c|}{ Lower-middle income } \\
\hline Argentina & 55.7 & 32.3 & 12.0 & 0.0 & 46.5 \\
\hline Bulgaria & 80.8 & 9.6 & 9.6 & 0.0 & 28.1 \\
\hline Iran & 82.2 & 17.8 & 0.0 & 0.0 & 37.7 \\
\hline Romania & 82.8 & 17.2 & 0.0 & 0.0 & 72.5 \\
\hline \multicolumn{6}{|c|}{ Upper-middle income } \\
\hline Brazil & 3.2 & 96.0 & 0.8 & 0.0 & 219.5 \\
\hline Czechoslovakia & 63.8 & 5.2 & 31.1 & 0.0 & 79.1 \\
\hline Former USSR & 73.6 & 13.5 & 12.9 & 0.0 & $1,649.0$ \\
\hline Hungary & 51.0 & 0.7 & 48.6 & 0.0 & 28.6 \\
\hline Korea (South) & 45.0 & 4.9 & 50.2 & 0.0 & 94.5 \\
\hline Mexico & 75.1 & 20.4 & 0.0 & 4.6 & 111.6 \\
\hline South Africa & 97.0 & 0.5 & 2.5 & 0.0 & 157.5 \\
\hline Yugoslavia & 61.8 & 28.4 & 5.6 & 4.1 & 83.5 \\
\hline \multicolumn{6}{|l|}{ High income } \\
\hline Belgium & 35.1 & 0.6 & 64.3 & 0.0 & 64.1 \\
\hline Canada & 25.6 & 57.0 & 17.4 & - & 459.2 \\
\hline Finland & 29.3 & 28.4 & 42.1 & 0.0 & 45.4 \\
\hline France & 7.5 & 12.4 & 80.1 & 0.0 & 379.5 \\
\hline Germany & 63.5 & 3.4 & 33.1 & 0.0 & 484.3 \\
\hline Japan & 61.2 & 12.8 & 25.8 & 0.0 & 704.7 \\
\hline Netherlands & 93.4 & - & 6.5 & - & 62.0 \\
\hline Spain & 47.8 & 12.9 & 39.3 & 0.0 & 142.9 \\
\hline Sweden & 1.9 & 49.7 & 48.4 & 0.0 & 136.1 \\
\hline Switzerland & 1.4 & 52.5 & 45.9 & 0.0 & 49.7 \\
\hline United Kingdom & 77.3 & 2.2 & 20.5 & - & 292.4 \\
\hline United States & 71.0 & 9.5 & 19.0 & 0.4 & $2,780.8$ \\
\hline Cuba & 99.3 & 0.7 & 0.0 & 0.0 & 13.6 \\
\hline
\end{tabular}

SOURCE: United Nations (1991).

'Does not include the production of electricity for self-use (i.e., auto-producers).

'Electricity generated from oil, gas, and coal.

'Electricity generated from geothermal, solar, biomass, wind, and other renewable sources.

'A '-' signifies that the amount was less than $500 \mathrm{M} \mathrm{kWh}$. 
Table C.7. Production of conventional thermal electricity, nuclear countries, 1988

\begin{tabular}{|c|c|c|c|c|}
\hline & \multicolumn{3}{|c|}{$\%$ composition } & \multirow{2}{*}{$\begin{array}{c}\text { Total } \\
\left(10^{3} \mathrm{TOE}\right)\end{array}$} \\
\hline & Coal & Oil & Gas & \\
\hline \multicolumn{5}{|l|}{ Low income } \\
\hline China & 87.7 & 12.0 & 0.3 & 116,729 \\
\hline India & 89.1 & 5.4 & 5.5 & 47,280 \\
\hline Pakistan & 0.3 & 44.9 & 54.8 & 3,776 \\
\hline \multicolumn{5}{|c|}{ Lower-middle income } \\
\hline Argentina & 3.6 & 40.2 & 56.2 & 7,358 \\
\hline Bulgaria & 85.3 & 14.7 & 0.0 & 13,033 \\
\hline Iran & 0.0 & 55.2 & 44.8 & 10,713 \\
\hline Romania & 48.3 & 22.9 & 28.8 & 20,142 \\
\hline \multicolumn{5}{|c|}{ Upper-middle income } \\
\hline Brazil & 37.1 & 62.9 & 0.0 & 2,584 \\
\hline Czechoslovakia & 73.2 & 14.5 & 12.3 & 26,484 \\
\hline Former USSR & 31.0 & 20.0 & 48.9 & 399,274 \\
\hline Hungary & 46.1 & 16.4 & 37.5 & 7,807 \\
\hline Korea (South) & 48.7 & 26.3 & 25.1 & 9,685 \\
\hline Mexico & 10.0 & 76.2 & 13.8 & 18,223 \\
\hline South Africa & 100.0 & 0.0 & 0.0 & 31,490 \\
\hline Yugoslavia & 83.5 & 12.9 & 3.6 & 15,020 \\
\hline \multicolumn{5}{|l|}{ High income } \\
\hline \multicolumn{5}{|l|}{ Belgium } \\
\hline \multicolumn{5}{|l|}{ Canada } \\
\hline \multicolumn{5}{|l|}{ Finland } \\
\hline \multicolumn{5}{|l|}{ France } \\
\hline \multicolumn{5}{|l|}{ Germany } \\
\hline \multicolumn{5}{|l|}{ Japan } \\
\hline \multicolumn{5}{|l|}{ Netherlands } \\
\hline \\
\hline \multirow{2}{*}{\multicolumn{5}{|c|}{$\begin{array}{l}\text { Sweden } \\
\text { Switzerland }\end{array}$}} \\
\hline & & & & \\
\hline \multicolumn{4}{|l|}{ United Kingdom } & United States \\
\hline Cuba & 0.0 & 100.0 & 0.0 & 3,723 \\
\hline
\end{tabular}




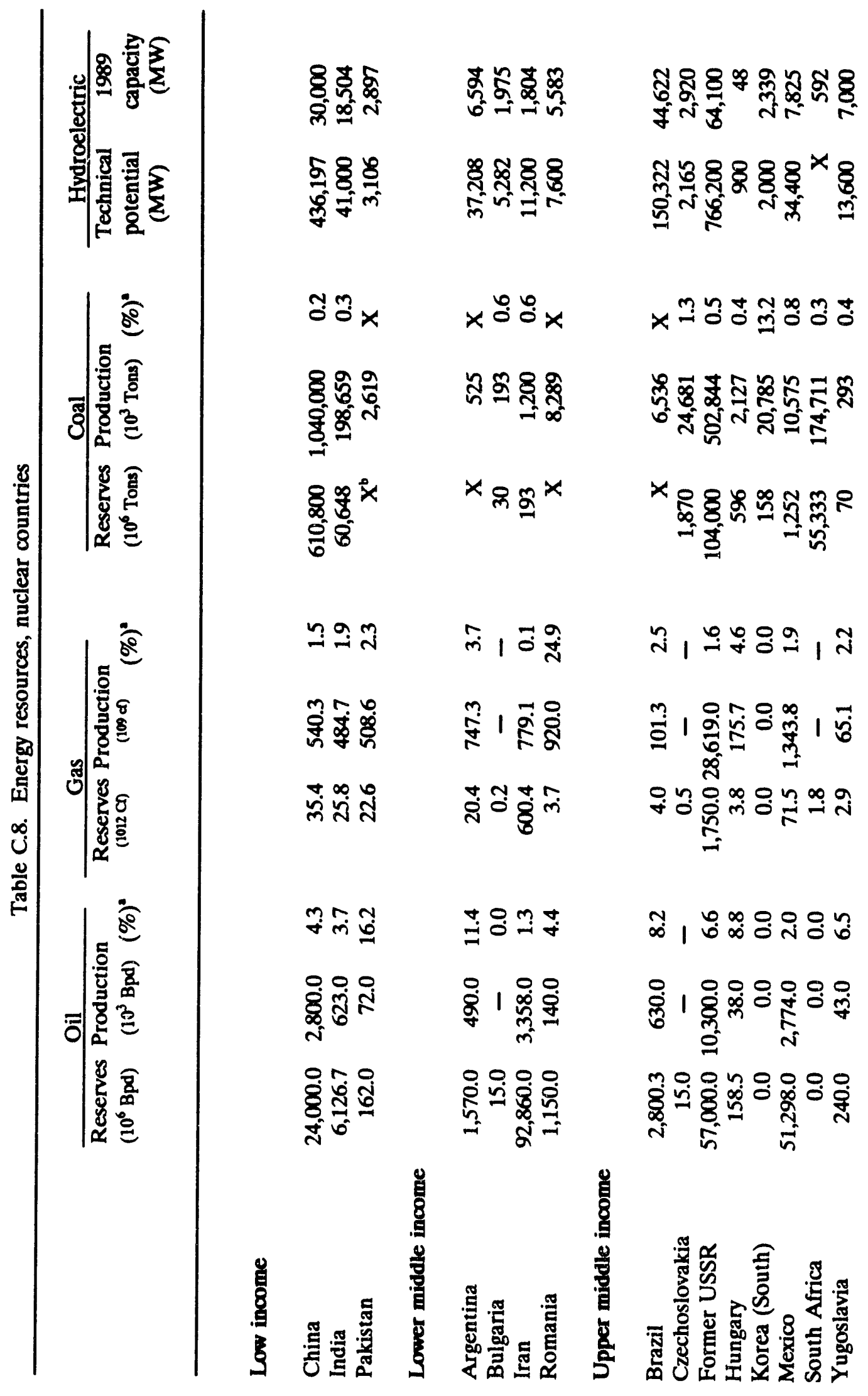




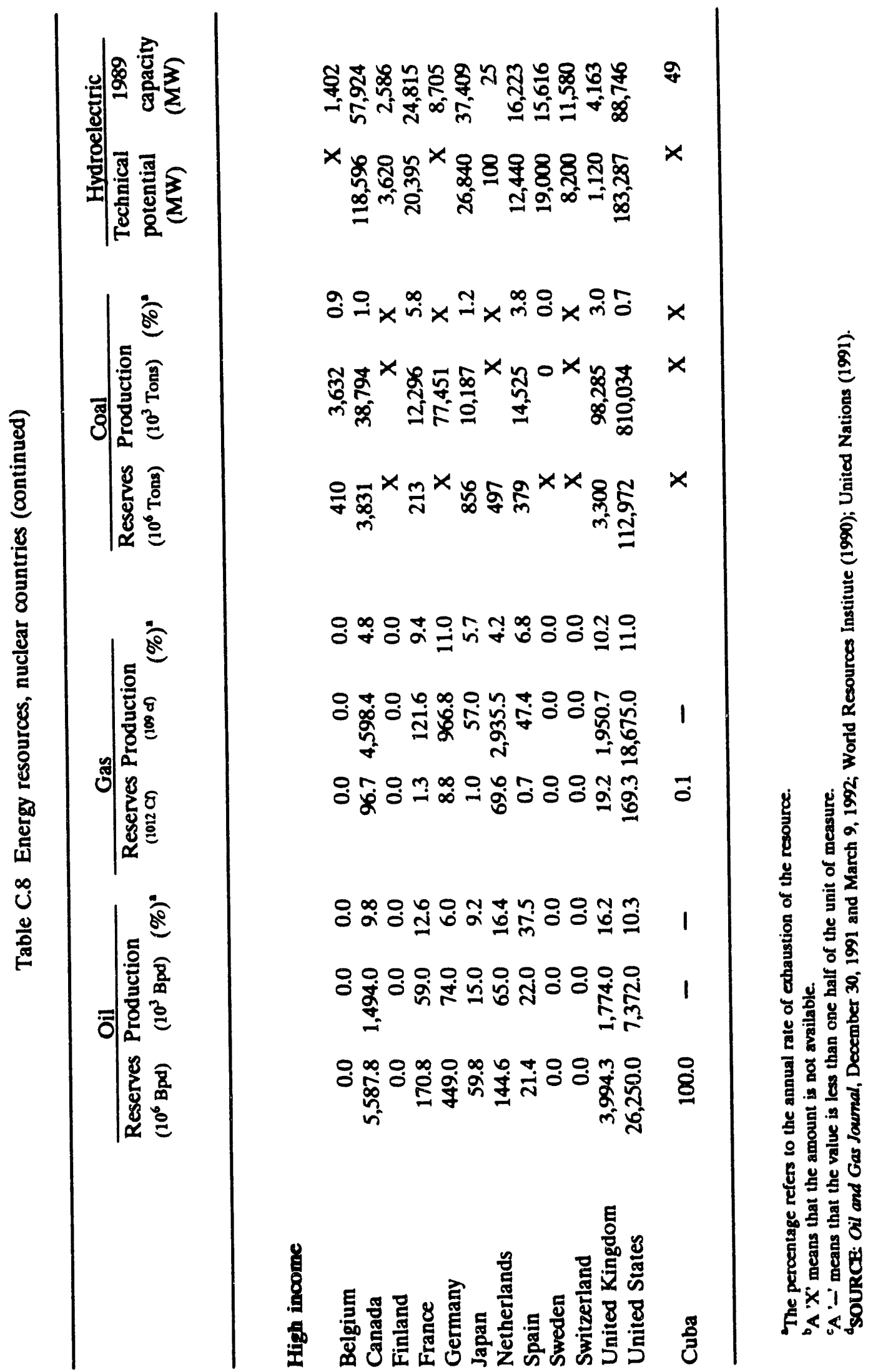




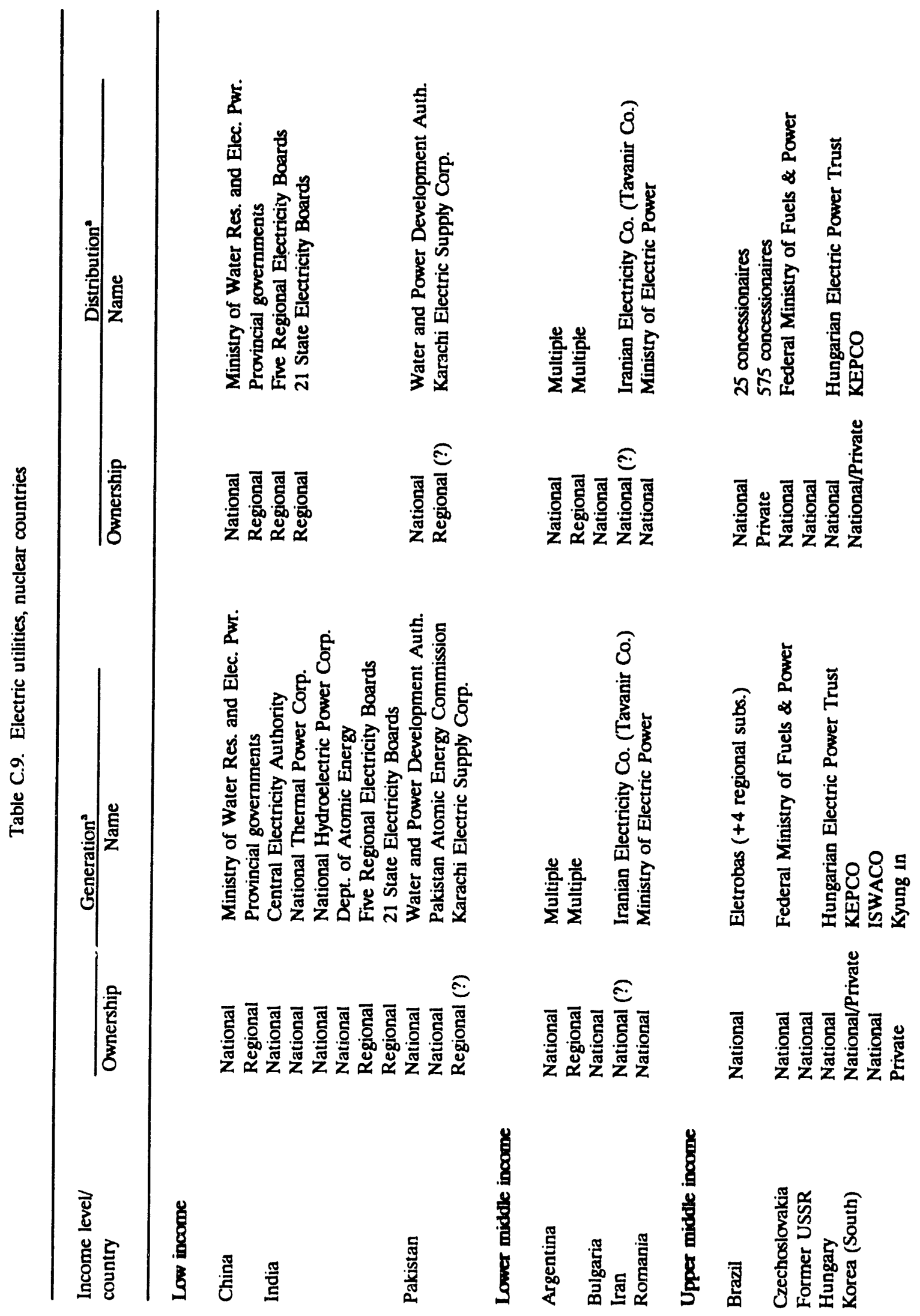




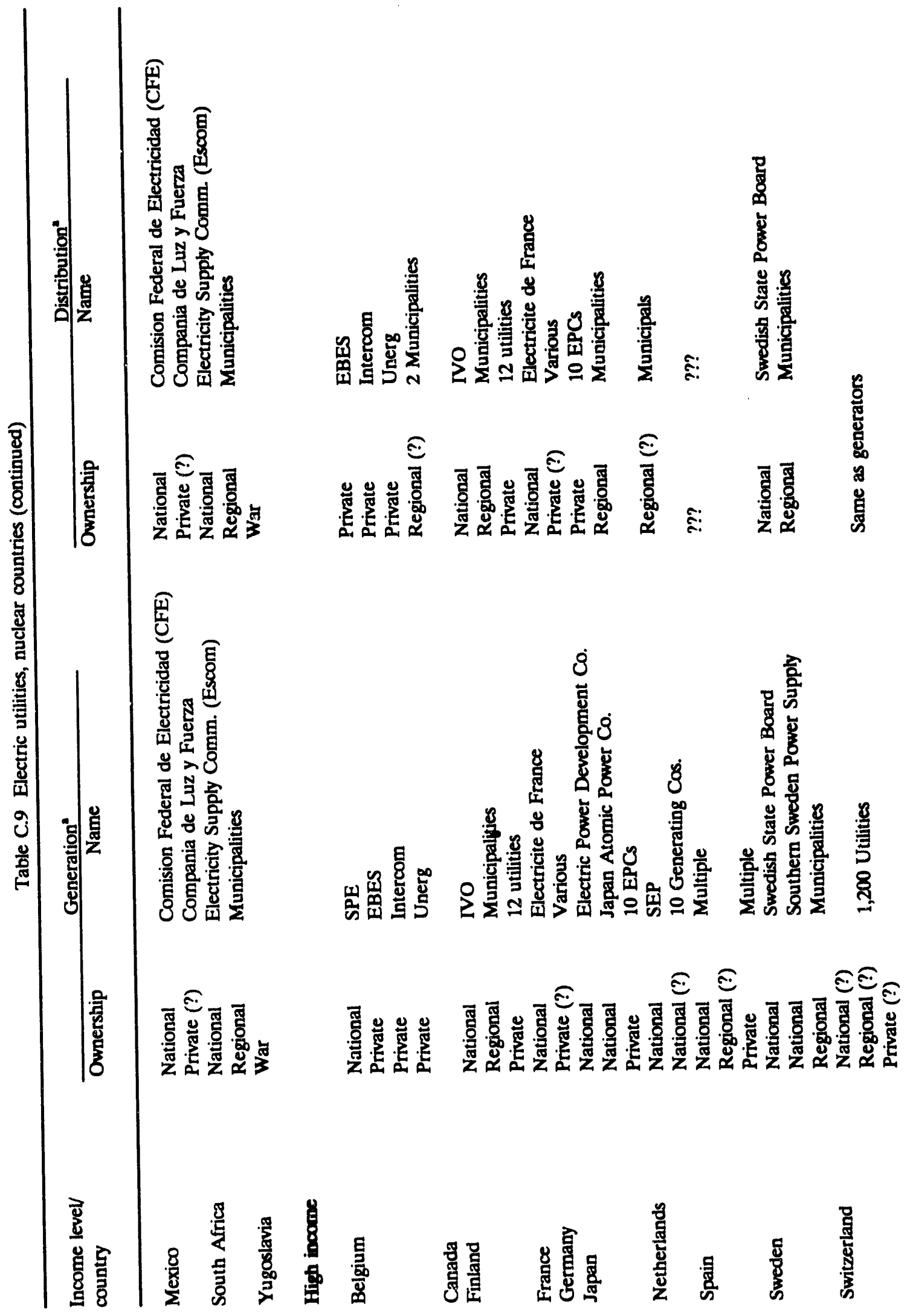




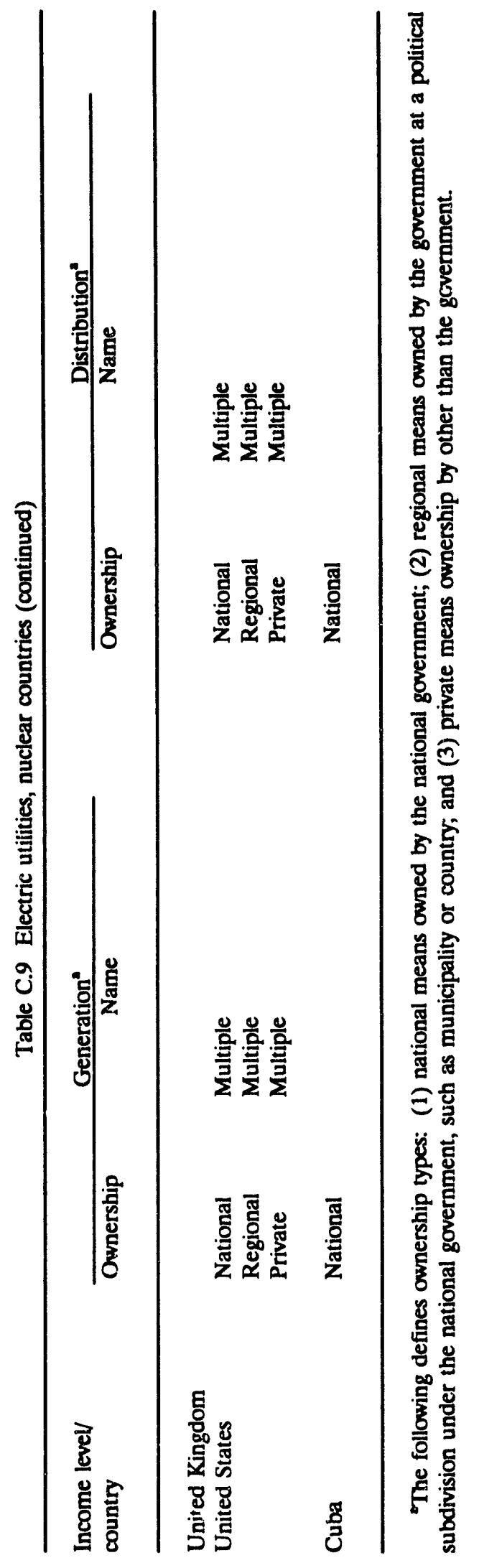


Appendix D. LIST OF NUCLEAR POWER REACTORS AND SUPPLIERS 


\section{Appendix D. WORLD LIST OF NUCLEAR POWER PLANTS OPERATING AND UNDER CONSTRUCTION}

Table D.1 provides a list of nuclear power reactors in operation or under construction by country, the utility that owns the plant, the reactor vendor supplying the nuclear system, and other auxiliary information. Countries are listed alphabetically except for the Former Soviet Union which has been placed at the end of the table with a separate listing for each independent republic. The table empirically shows the historical relationships between specific vendors and utilities. It also provides an estimate of the relative sizes of various nuclear reactor vendors and their capabilities. A vendor that has sold many reactors within the last decade clearly has significant industrial capabilities. Similarly, if a vendor sold many reactors over a long time period, there will be some demand for replacement components that may provide a continuing income to that vendor. The original vendor has a competitive advantage for replacement parts. Since the objective of the table is to understand the current nuclear power industry, shutdown or decommissioned power reactors are not included. Such facilities provide no sales to a nuclear power plant supplier.

The names and general characteristics of countries, utilities, and nuclear power plants seldom change. The same is not true for vendors. Some vendors have merged. Other vendors have changed names. Finally, many vendors have created temporary partnerships to build nuclear power plants in particular countries. Typically, such partnerships include a reactor vendor plus a local company with much of the work subcontracted to the local company. Such partnerships often reflect local desires to maximize local employment. To understand who the major vendors are, Table D1 lists the current vendor organization based on those identified in Table S1. The historical vendor is listed in parenthesis. For some of the older power reactors, there is some uncertainty about the parent crganization due to multiple mergers and name changes over a period of decades. 


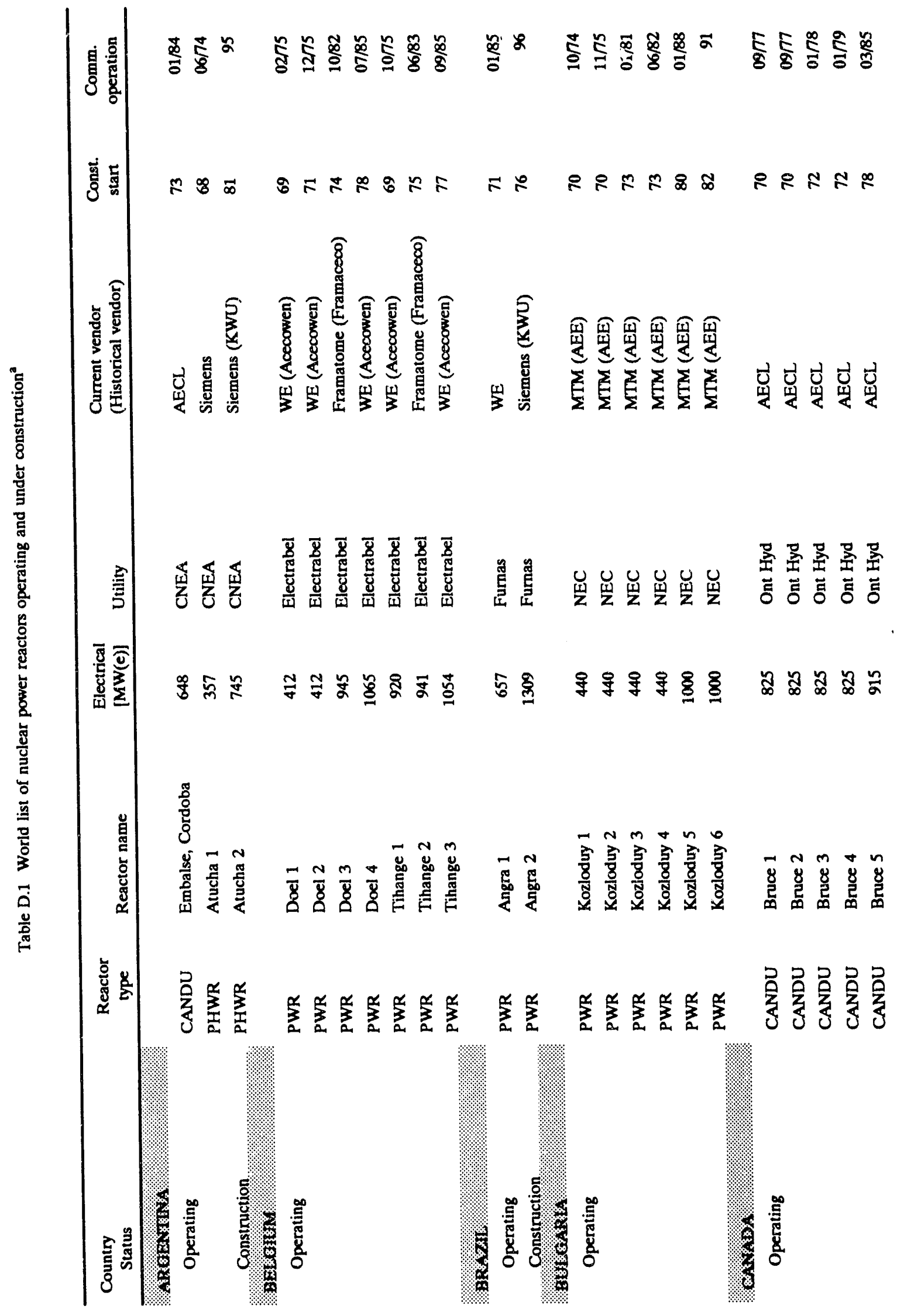




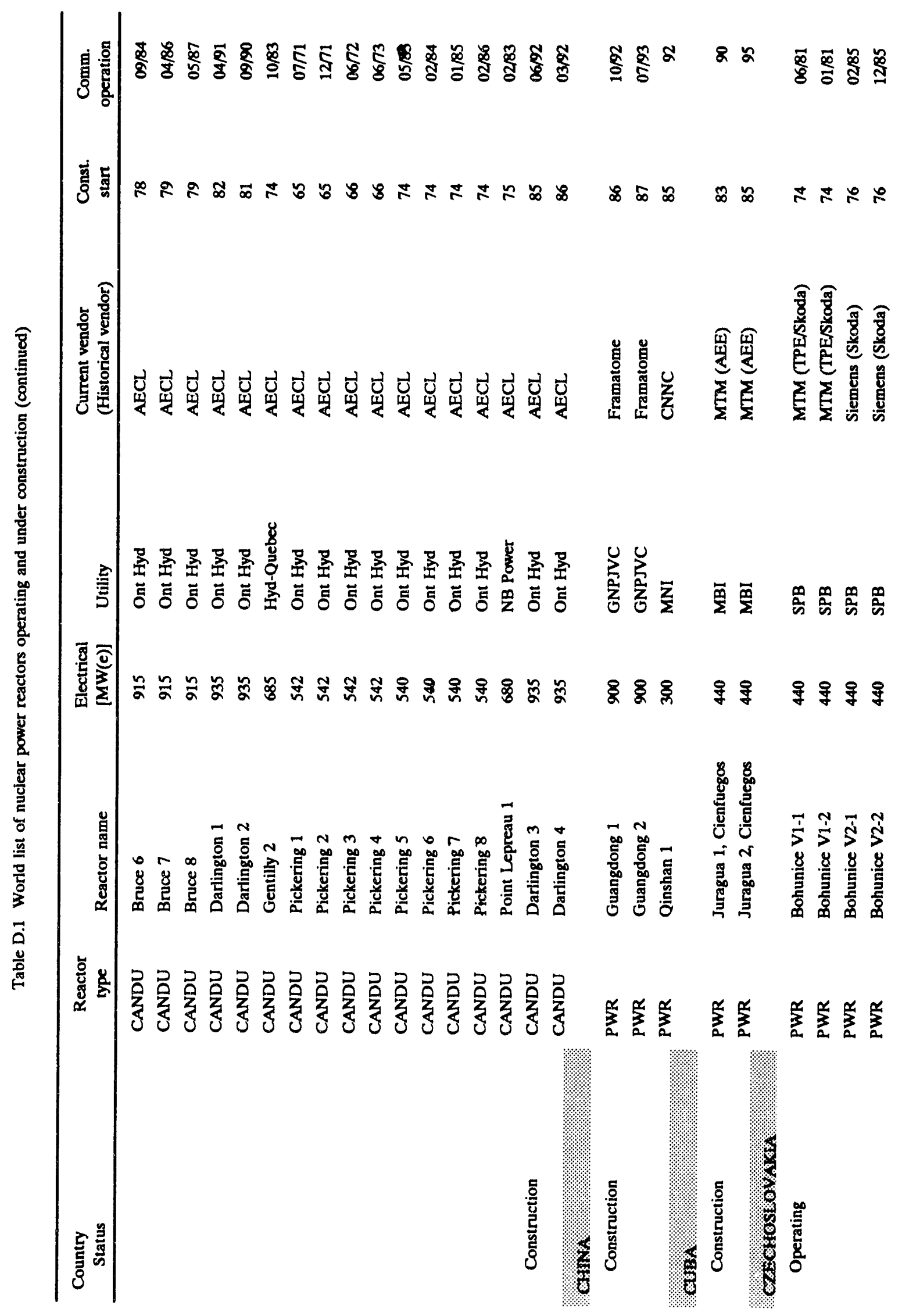




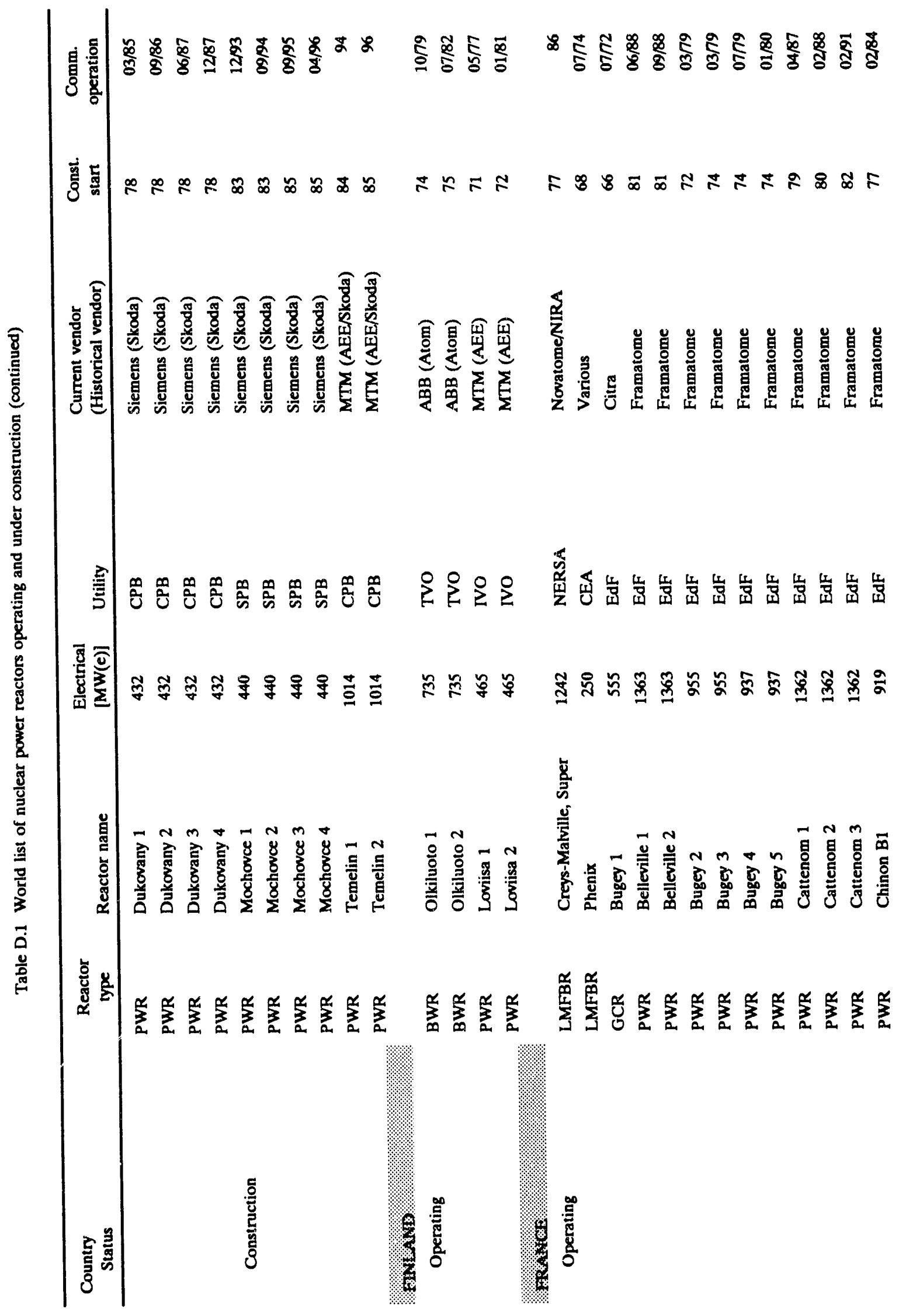




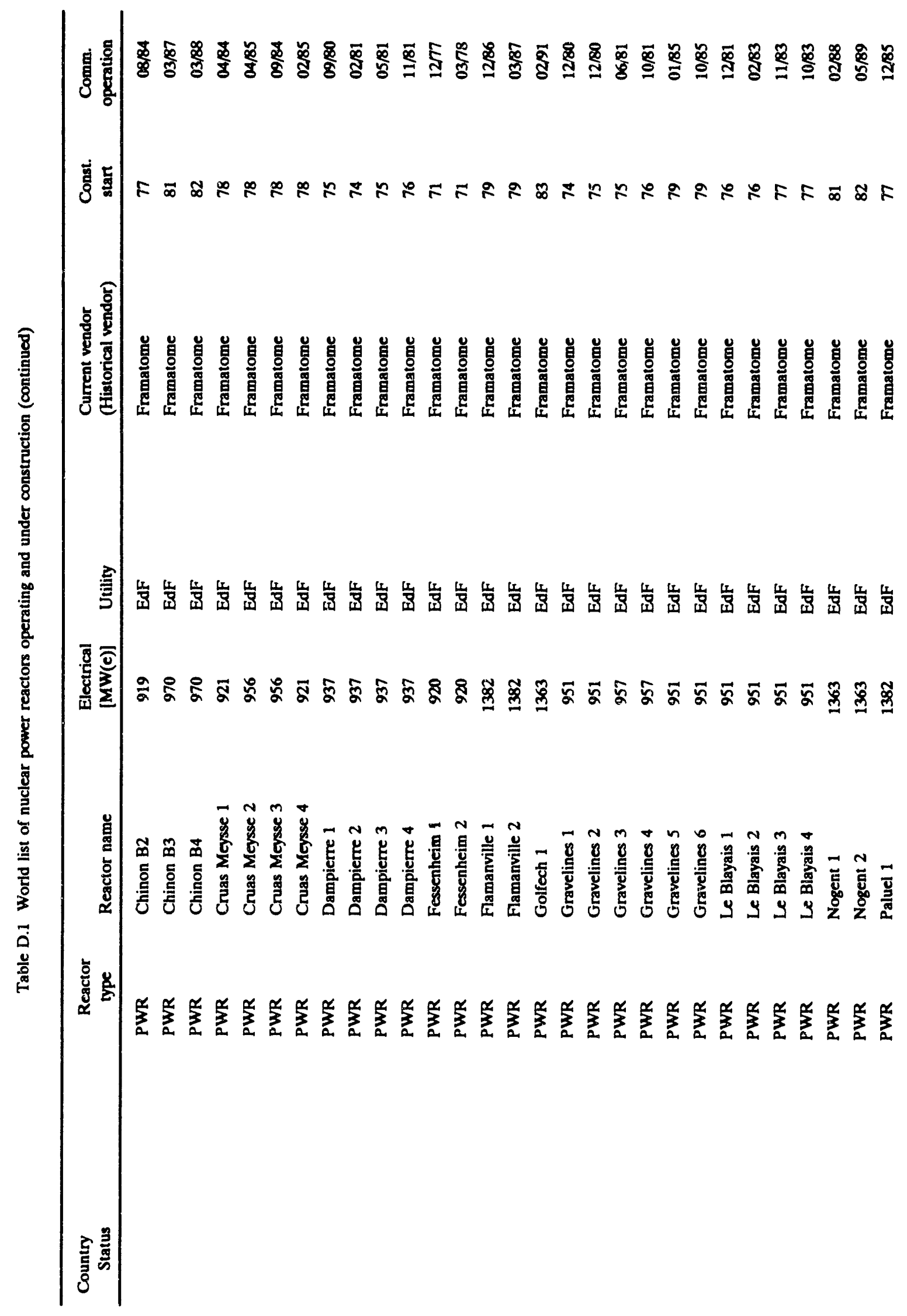




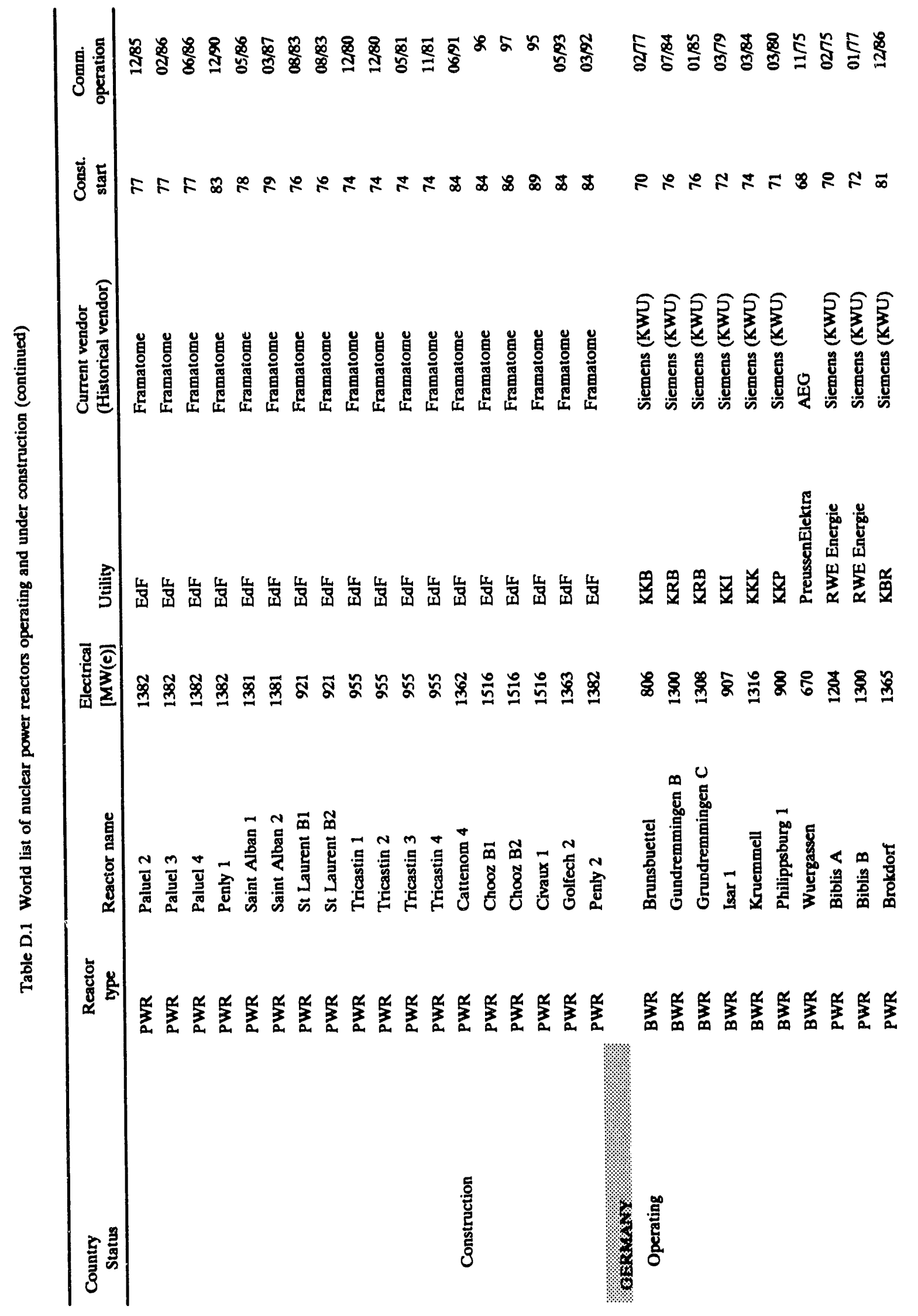




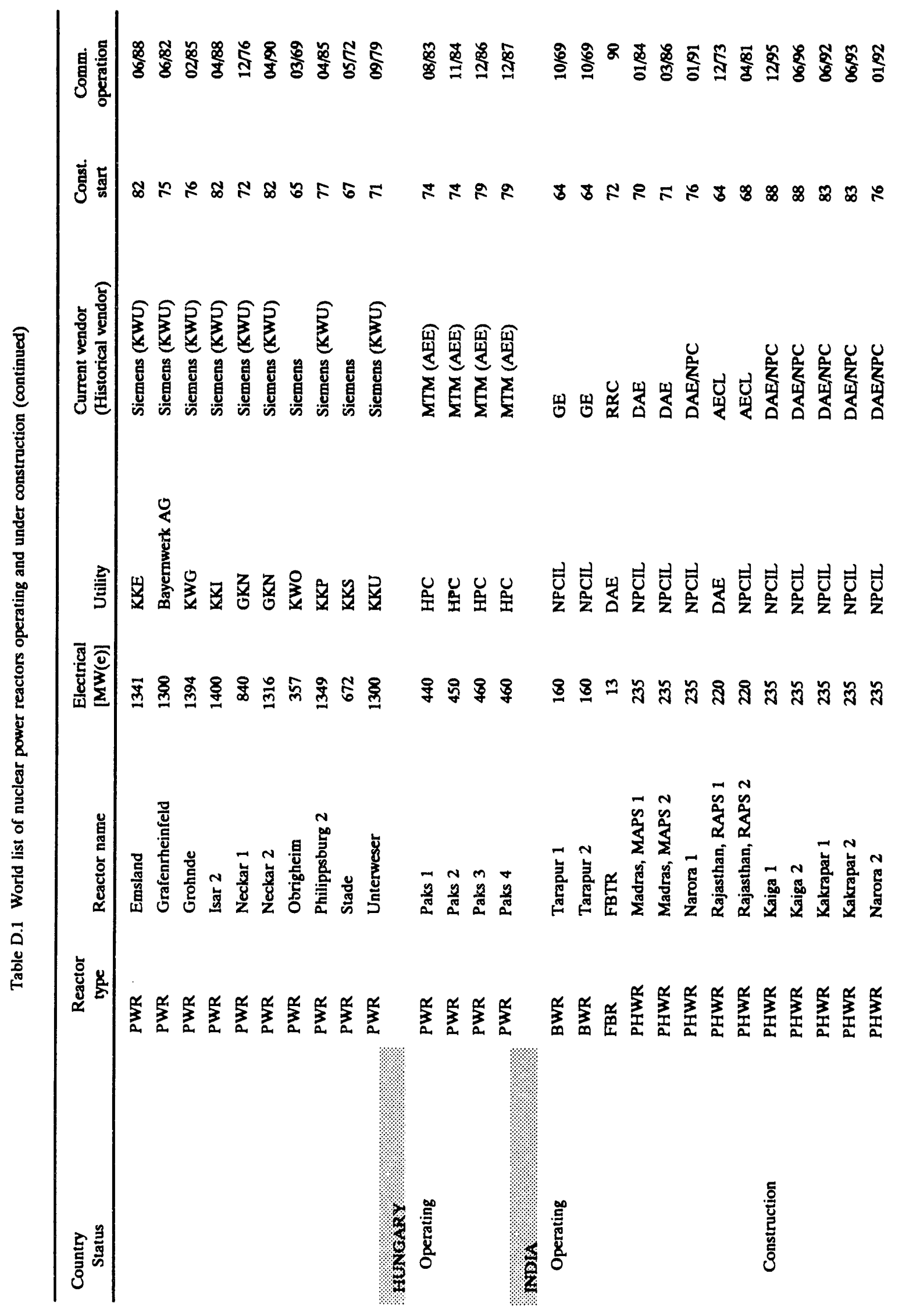




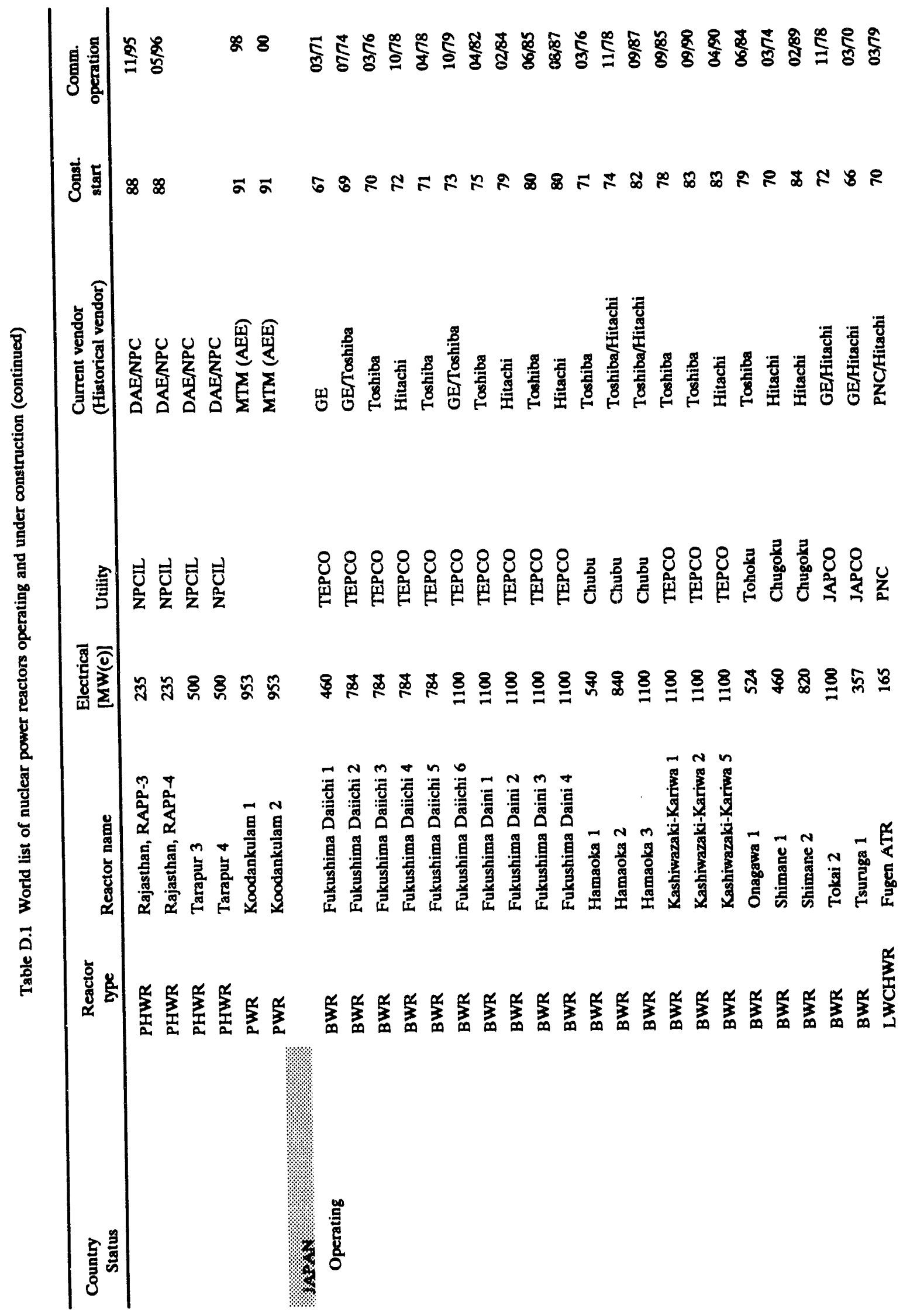




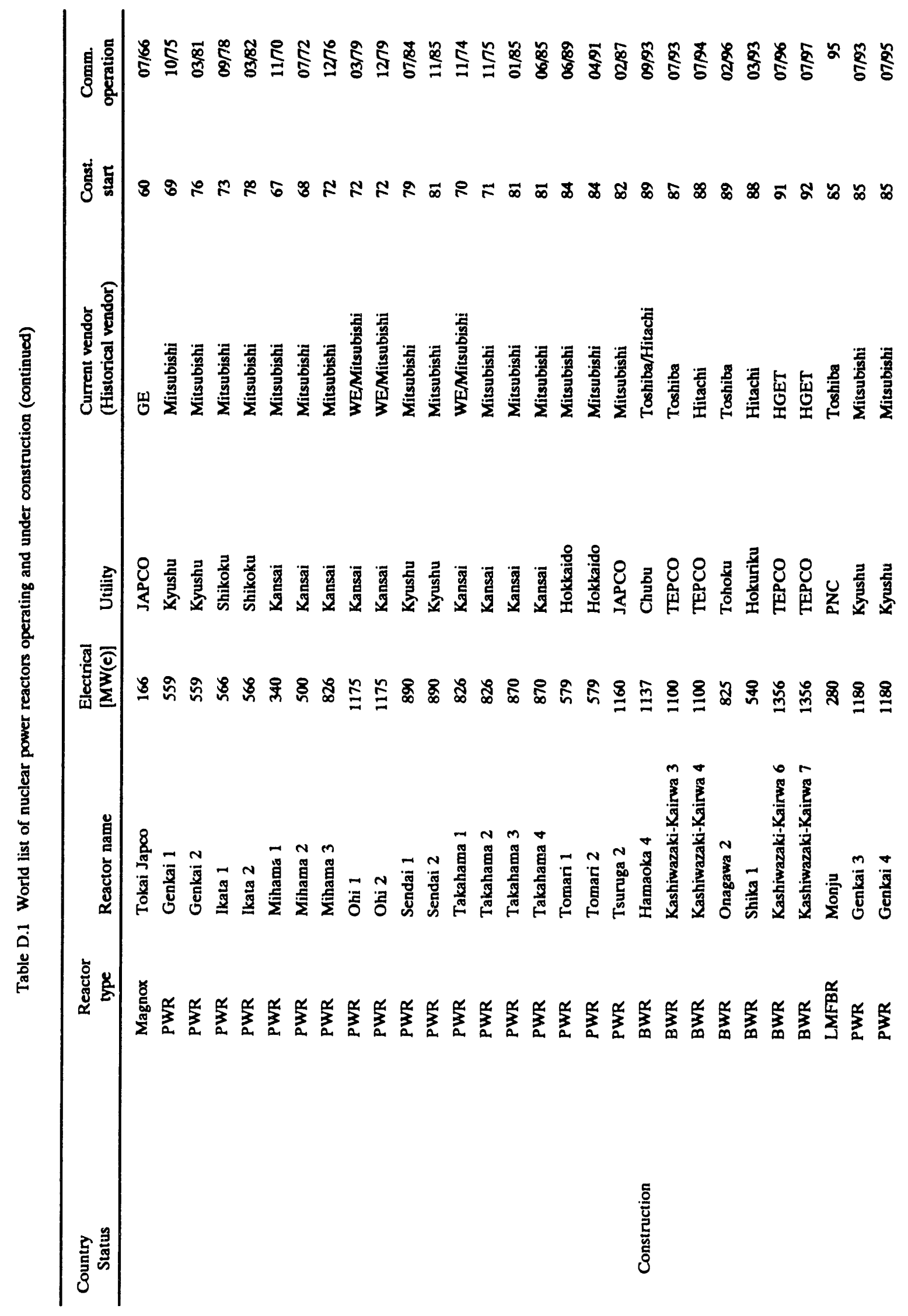




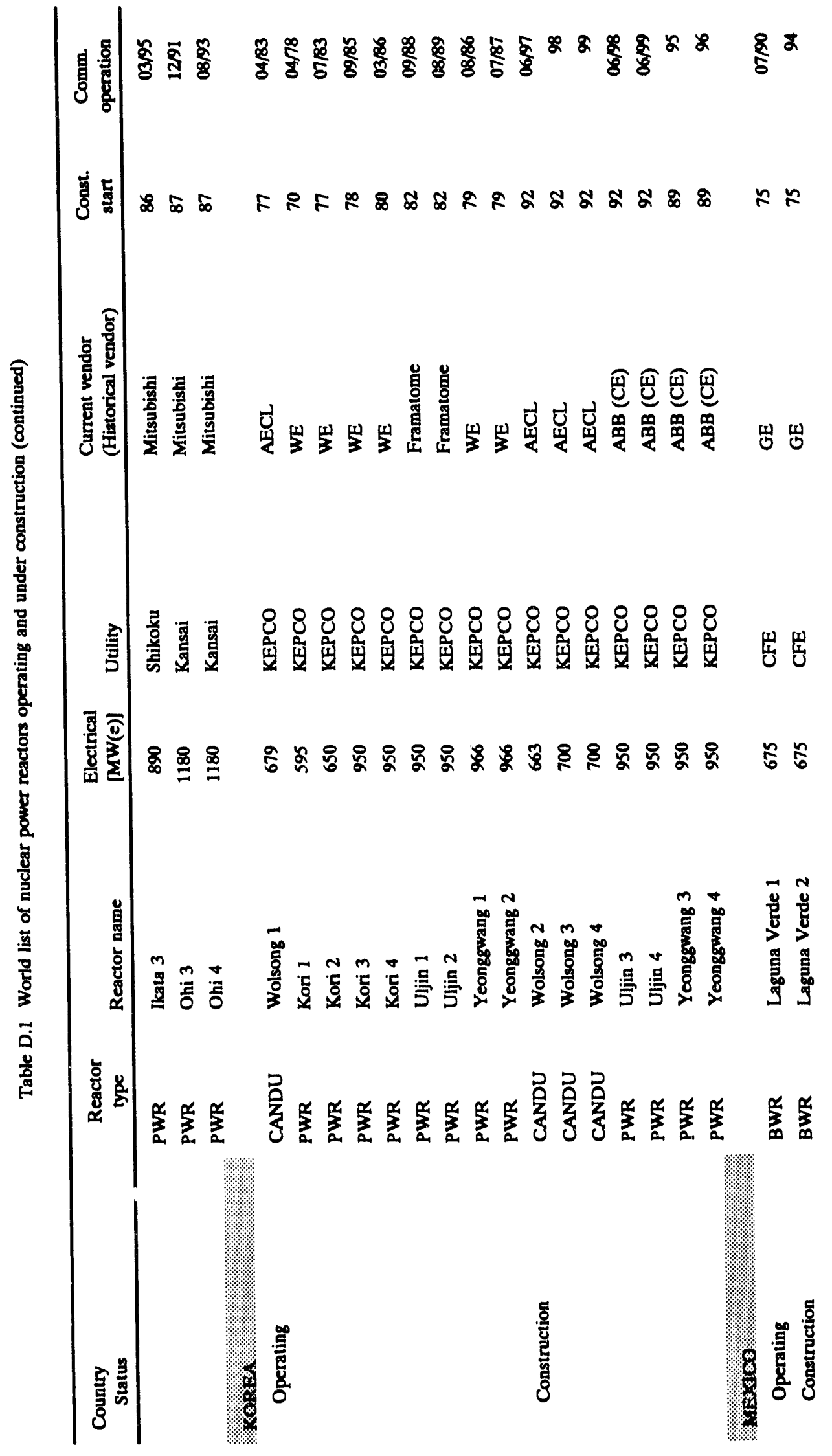




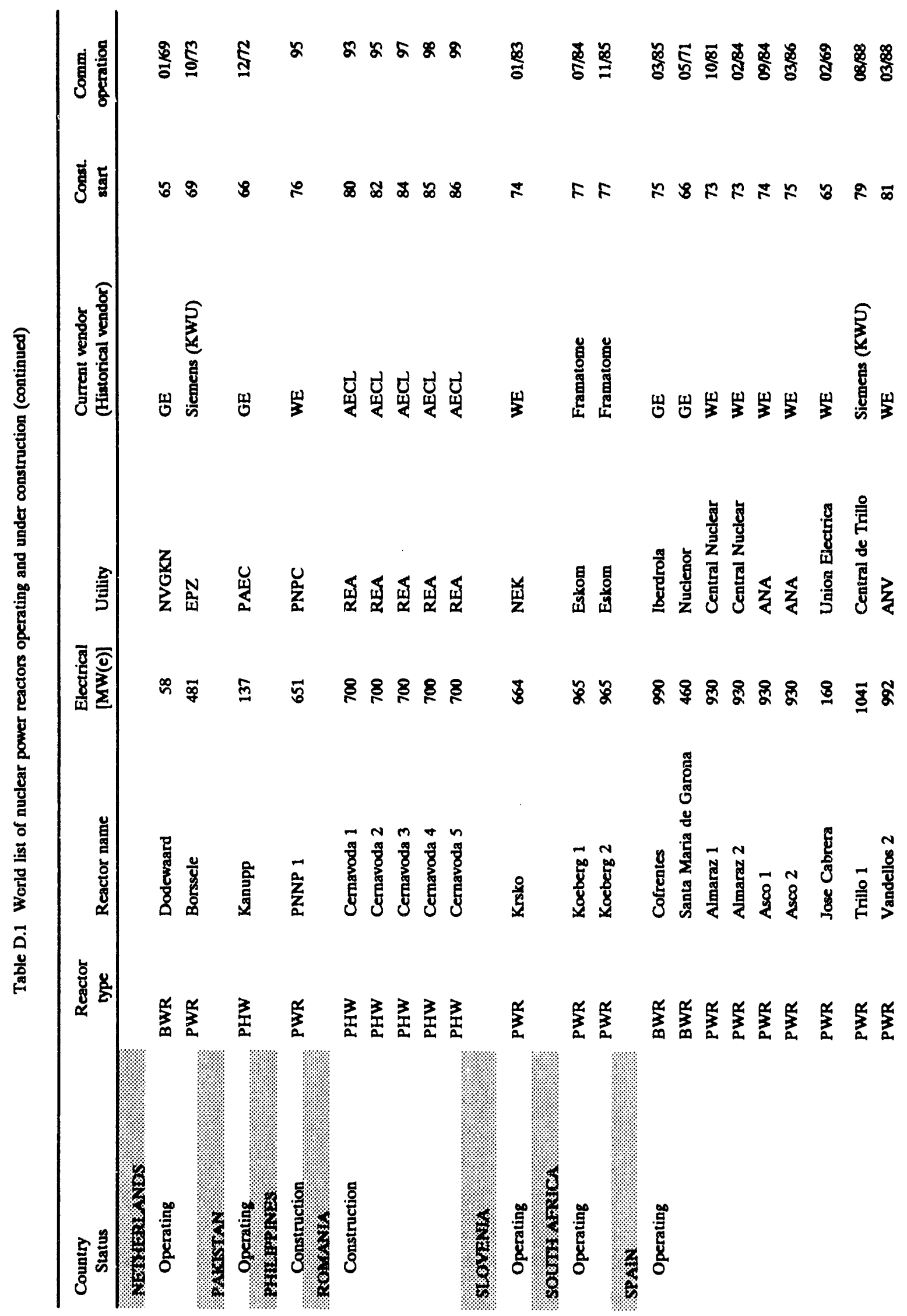




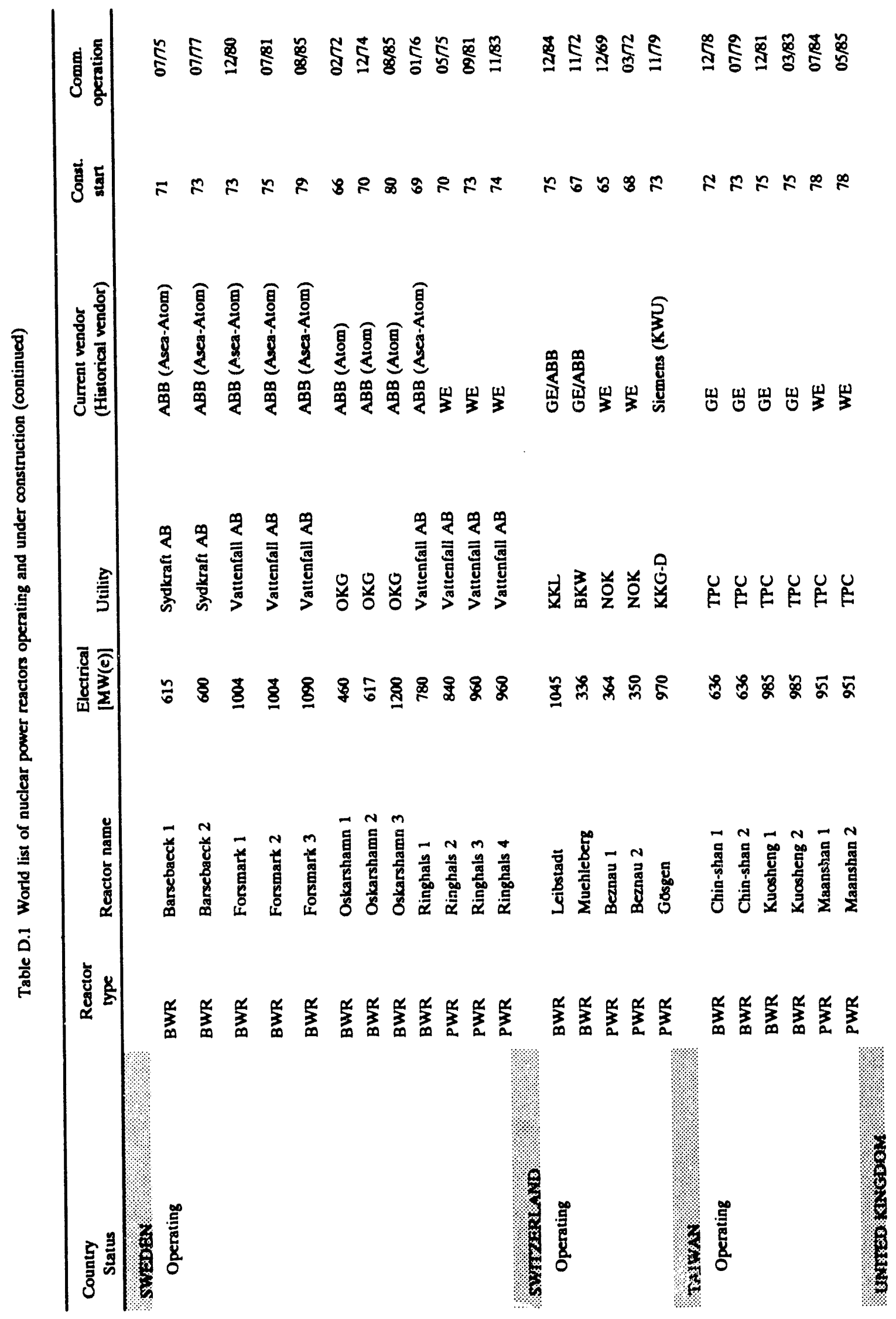




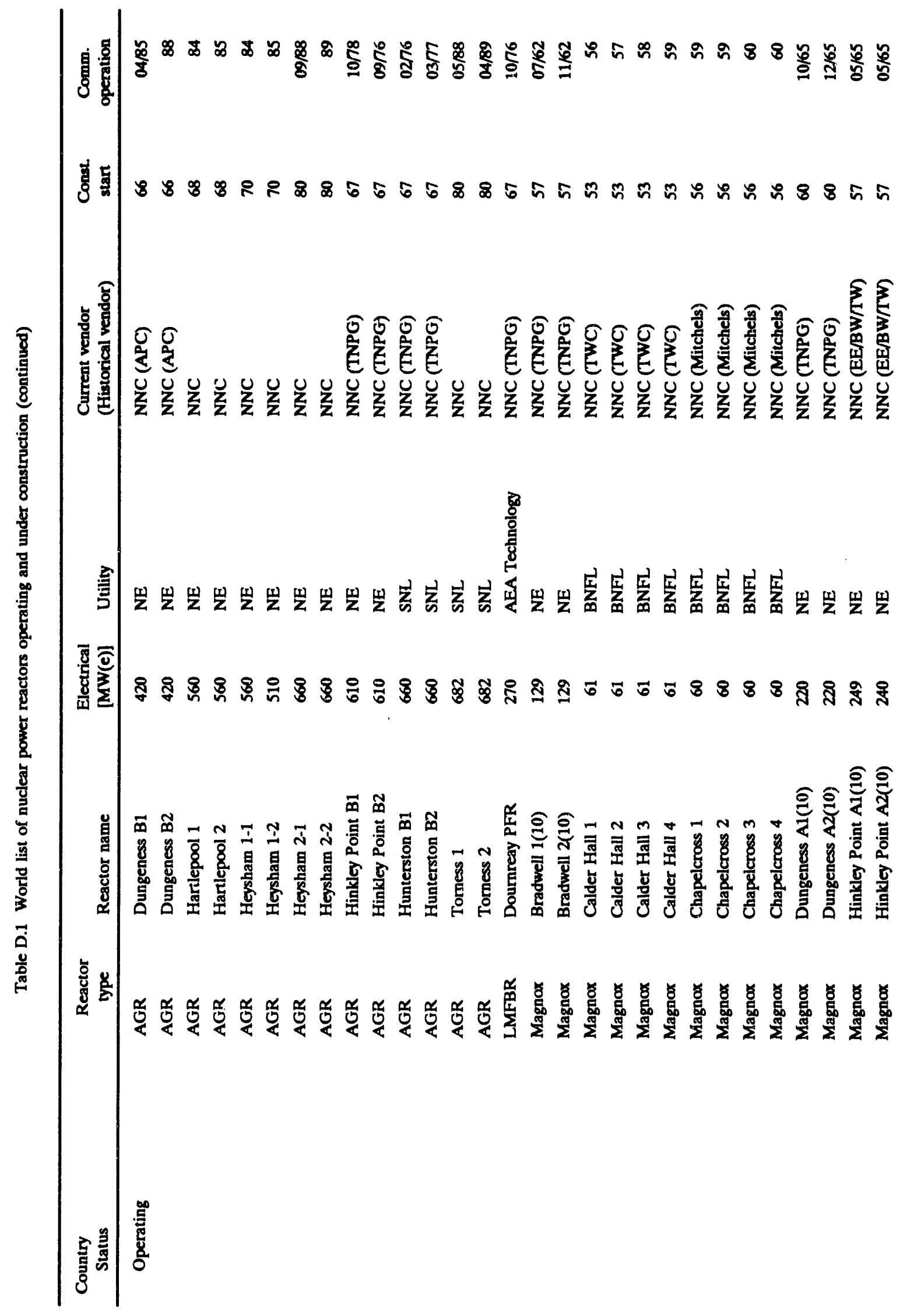




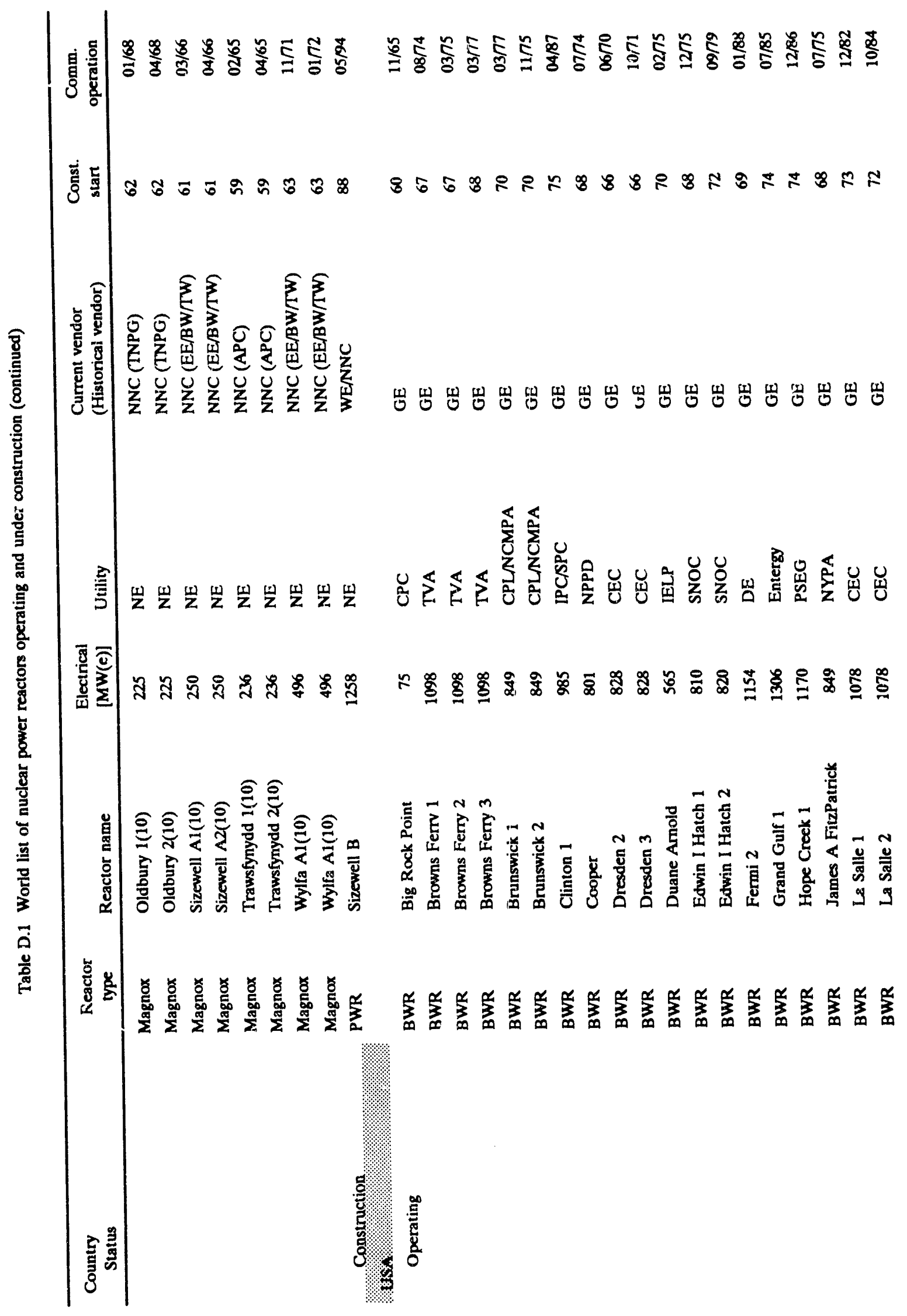




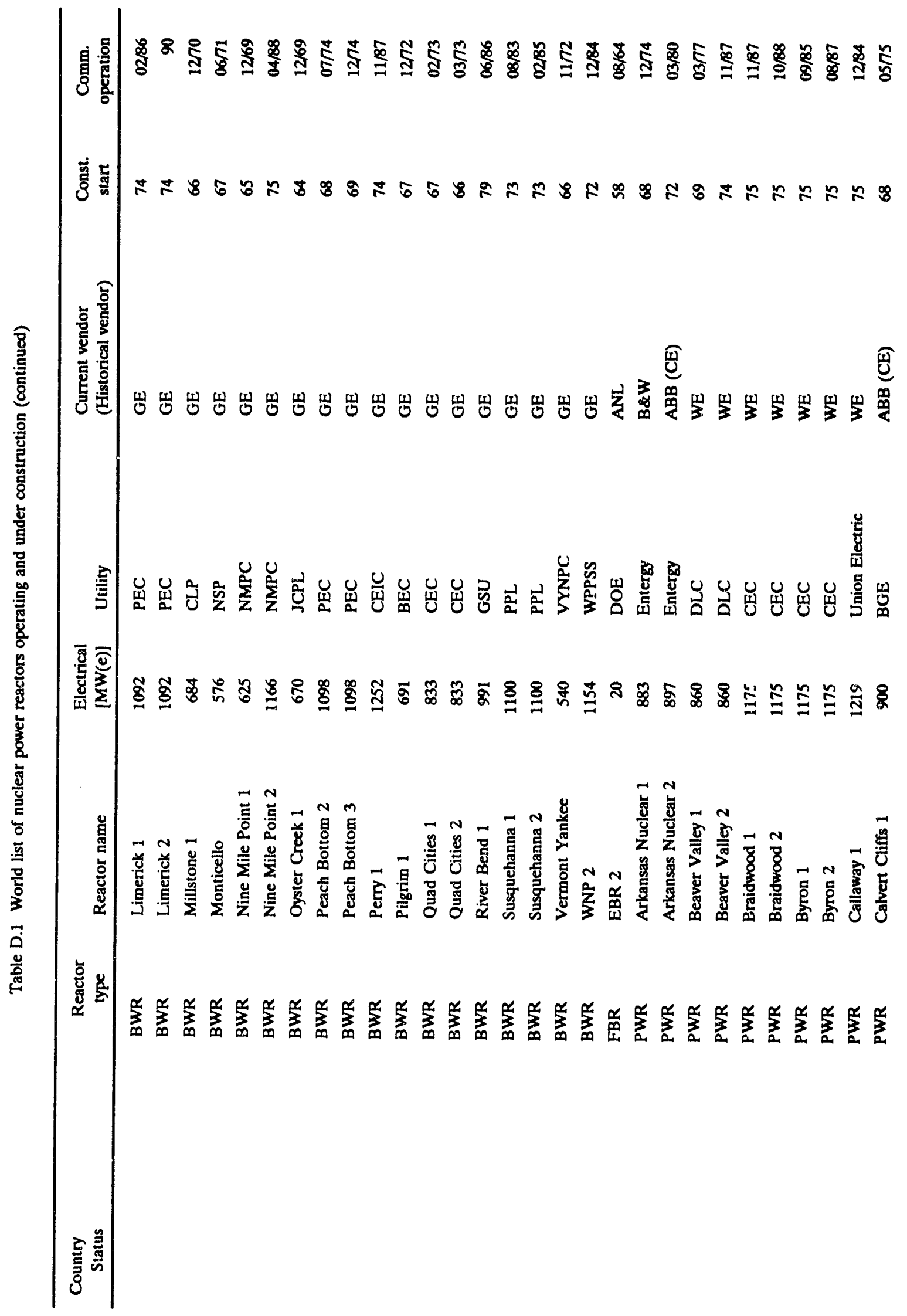




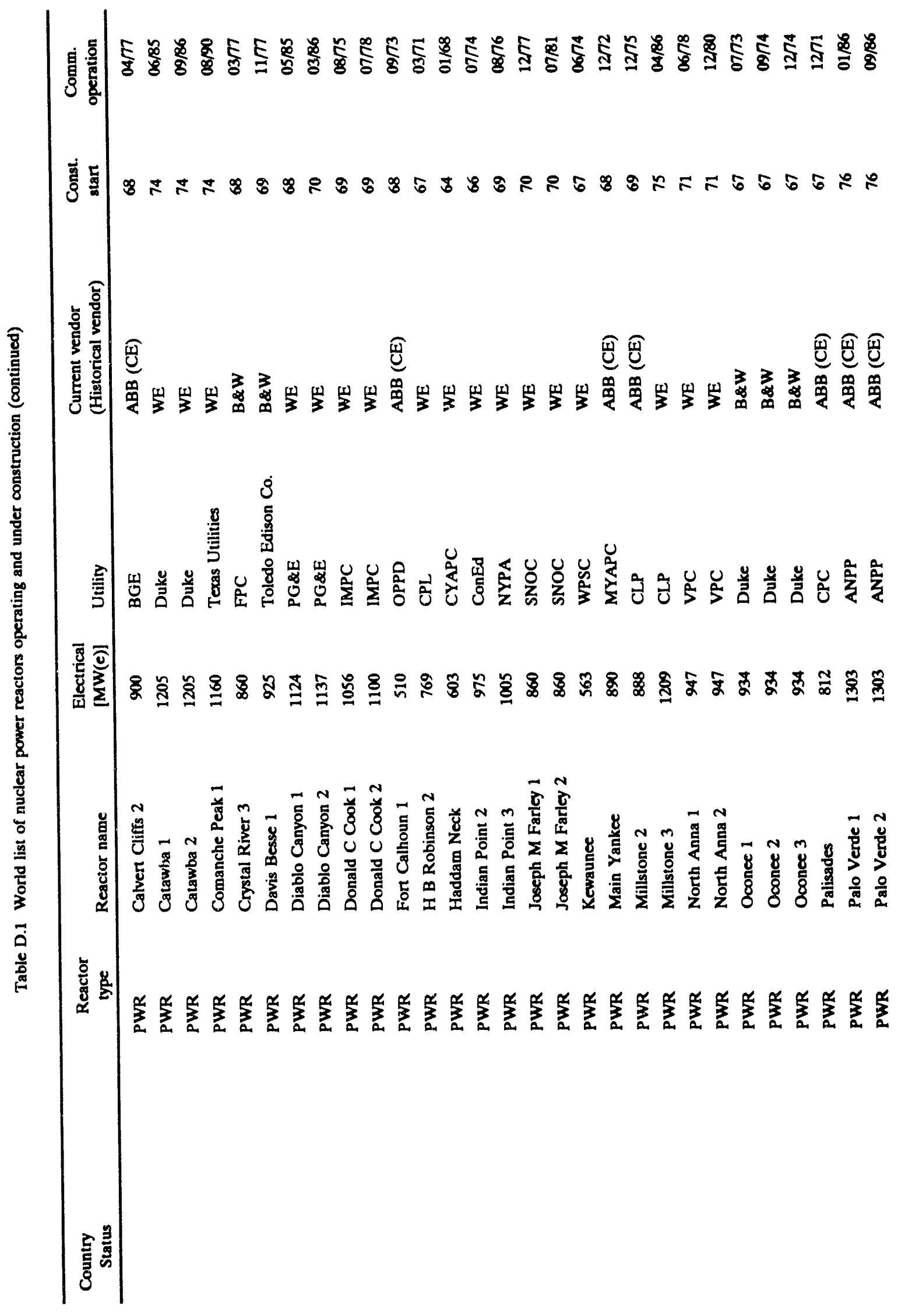




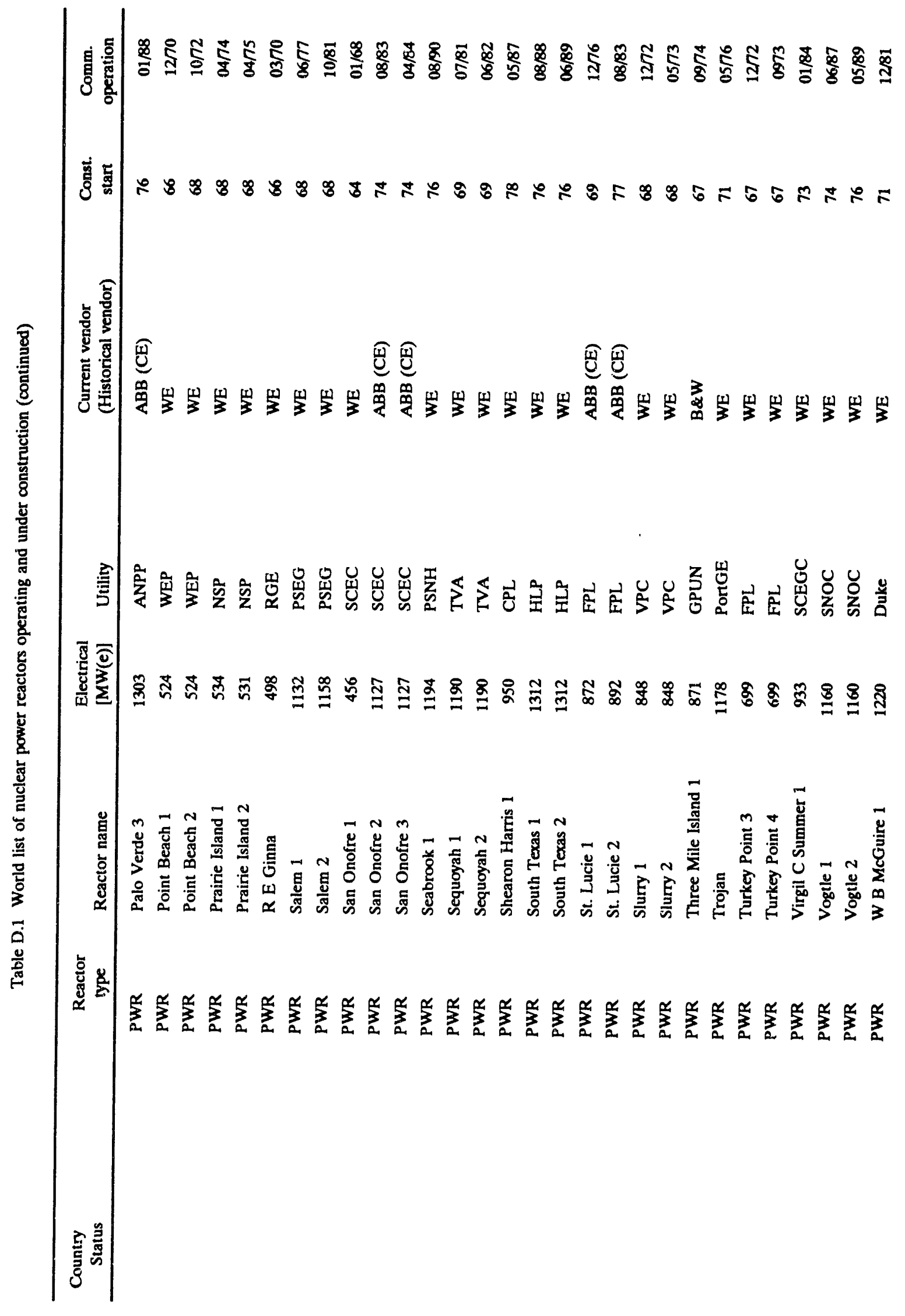


156

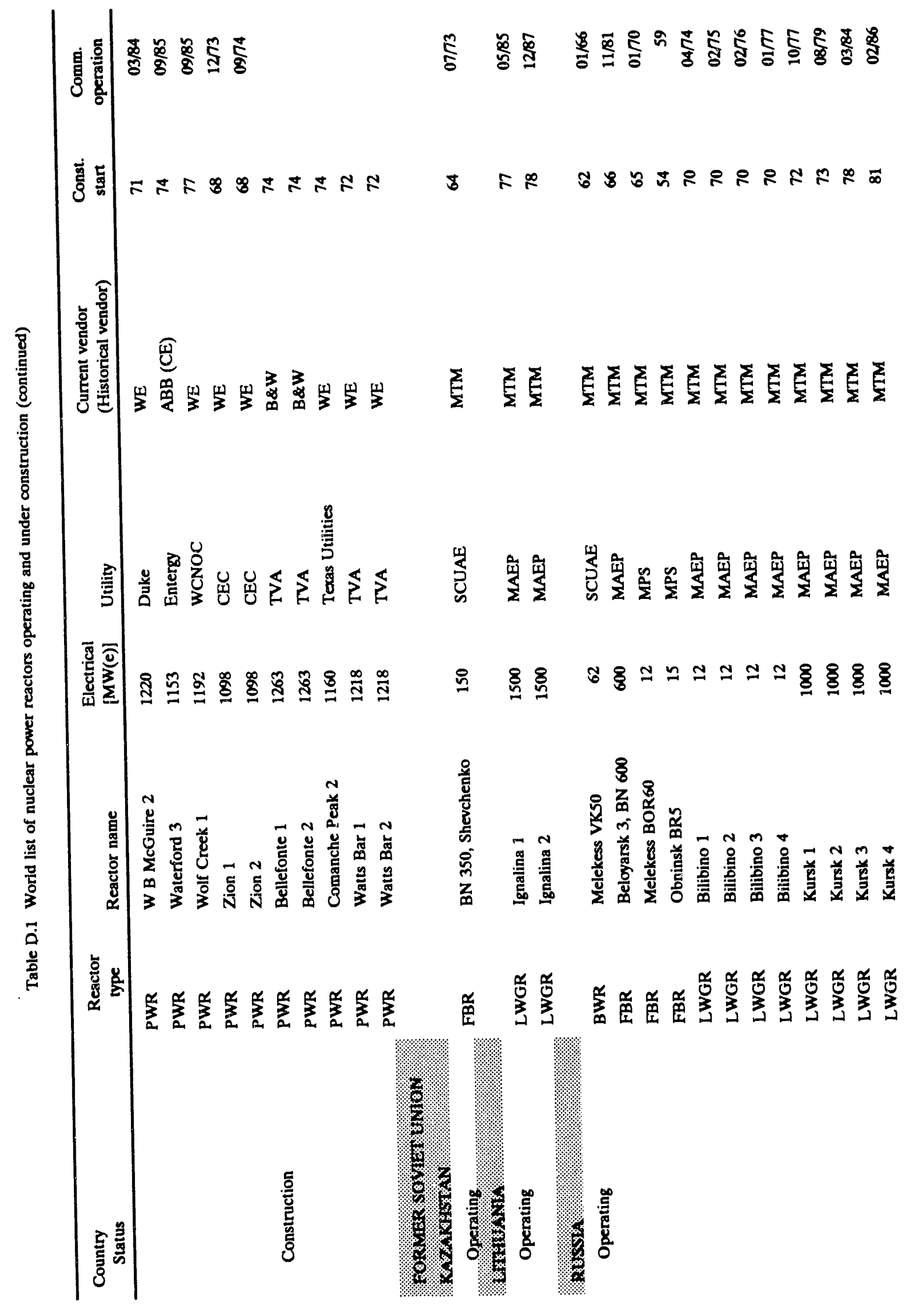




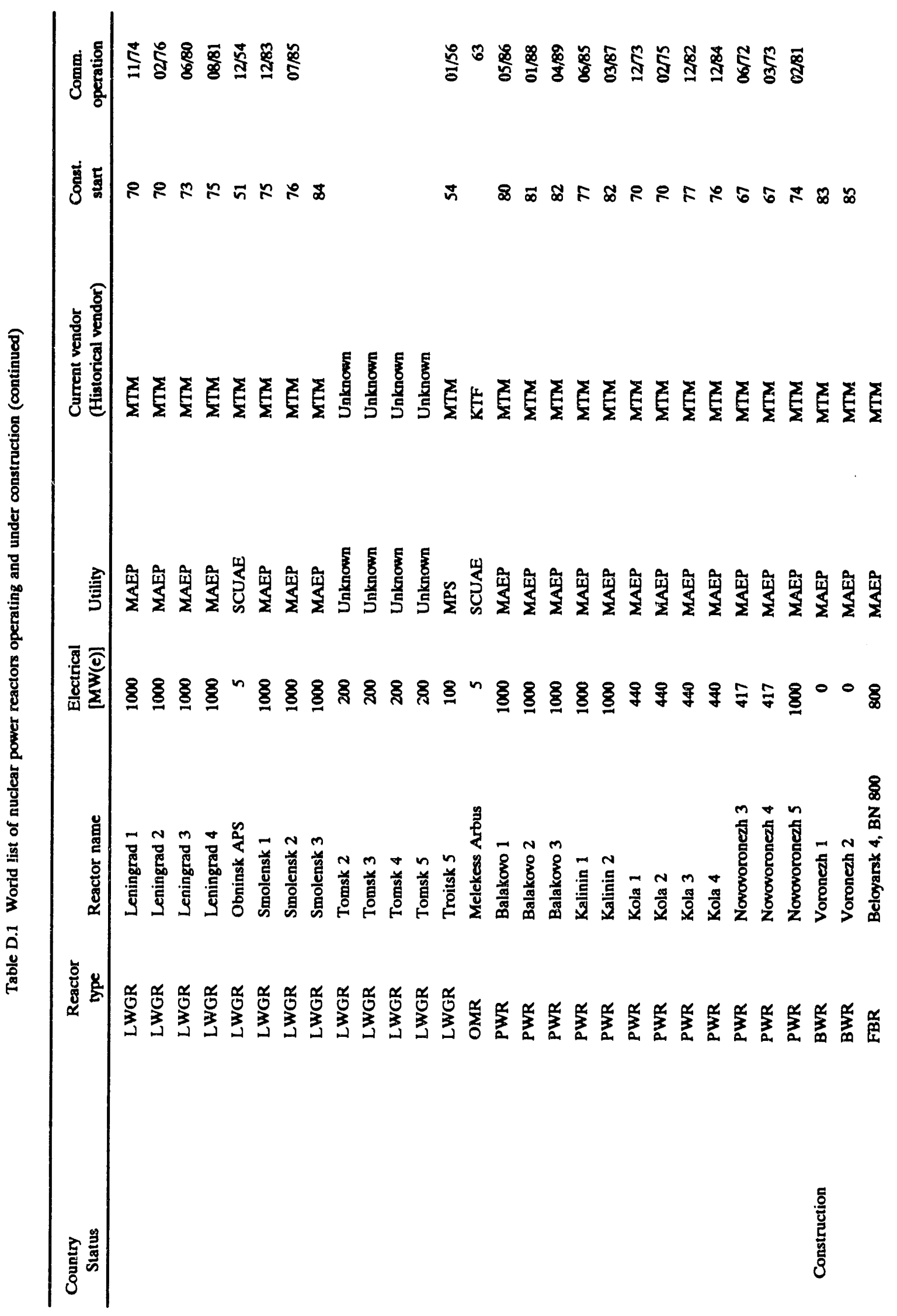




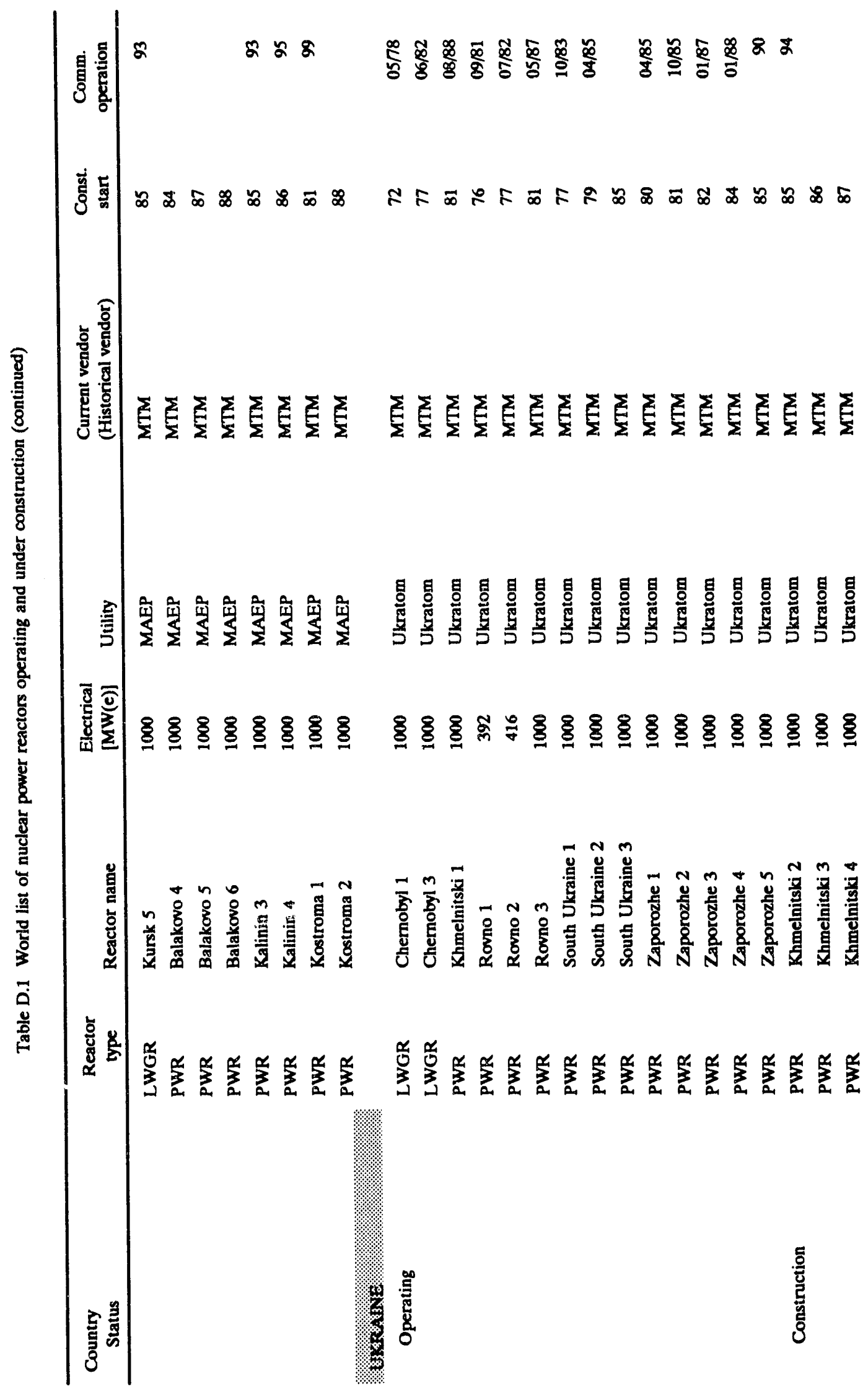


159

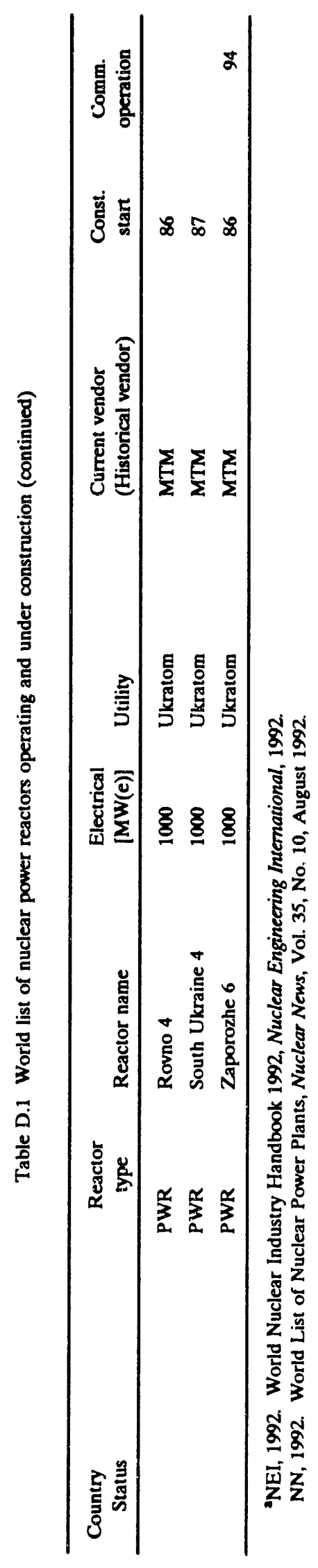



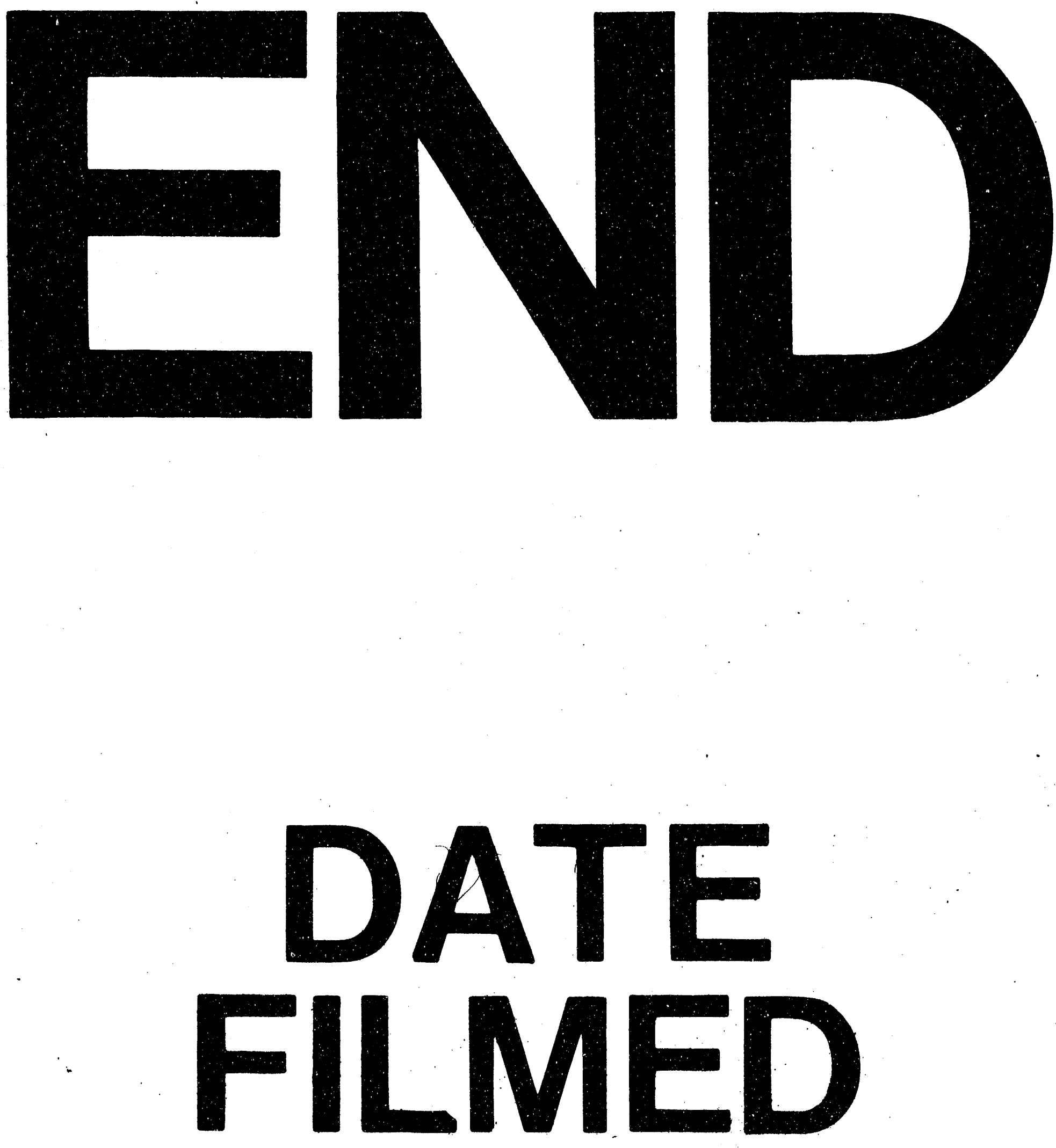

1

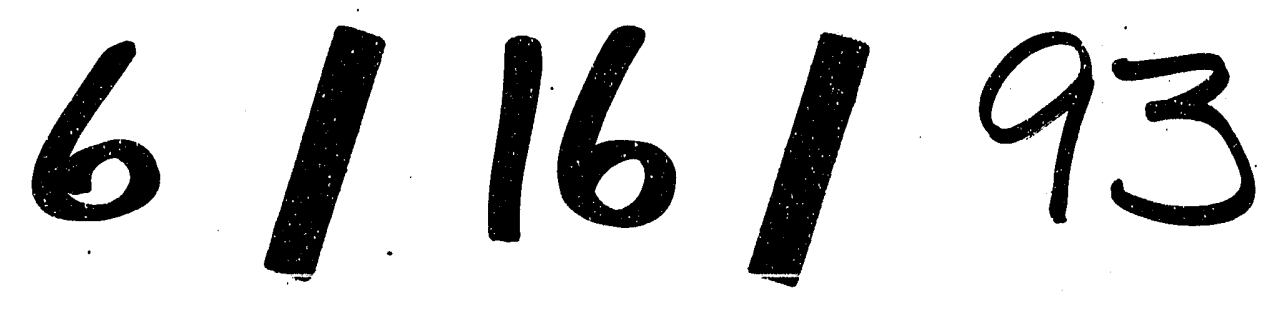


